\title{
A FEIRA DE CAPUAME PECUÁRIA, TERRITORIALIZAÇÃO E ABASTECIMENTO (BAHIA, SÉCULO XVIII)
}

\author{
JULIANA DA SILVA HENRIQUE
}

Dissertação apresentada ao

Programa de Pós-Graduação em História Econômica da

Faculdade de Filosofia, Letras e Ciências Humanas da Universidade de São Paulo, para a obtenção do Título de Mestre em História Econômica

Orientador: Prof. Dr. Pedro Puntoni

São Paulo 
UNIVERSIDADE DE SÃO PAULO

FACULDADE DE FILOSOFIA, LETRAS E CIÊNCIAS HUMANAS

DEPARTAMENTO DE HISTÓRIA

PROGRAMA DE PÓS-GRADUAÇÃO EM HISTÓRIA ECONÔMICA

\section{A FEIRA DE CAPUAME \\ PECUÁRIA, TERRITORIALIZAÇÃO \\ E ABASTECIMENTO \\ (BAHIA, SÉCULO XVIII)}

JULIANA DA SILVA HENRIQUE

São Paulo

2014 
Aos Boiadeiros. Getu, marrumba, getu!

À Isaquias Maria, Maria Rita, Lincoln e Araci Rodrigues. Todo meu amor e admiração!

Ao Prof. Dr. Istvan Jancsó. In memoriam. 


\title{
RESUMO
}

Esta investigação tem como principal objeto uma feira de gado localizada próxima a Cidade da Bahia de Todos os Santos: Capuame. Embora a feira fosse constantemente citada pela historiografia como uma das mais importantes do período setecentista, sabia-se muito pouco sobre sua existência. Não havia até o momento estudos a seu respeito fundamentados em consistente base documental. Assim, o primeiro objetivo desta pesquisa é preencher uma lacuna historiográfica, dedicando parte da dissertação ao estudo da primeira feira de gado da América Portuguesa. Compreender sua dinâmica de funcionamento em contexto colonial, analisar a sua relação com o processo de territorialização dos sertões baianos através da produção da mercadoria gado e a simultânea conexão com um dos principais portos e praças comerciais do Atlântico Sul são aspectos fundamentais para redimensionar a importância da pecuária para a reprodução da economia e da sociedade colonial.

\section{PALAVRAS-CHAVE:}

feira de gado, Capuame, pecuária, sertão, abastecimento, Bahia

\begin{abstract}
The main object of this investigation is a cattle fair located near the Cidade da Bahia de Todos os Santos: Capuame. Although the fair has been constantly quoted by historiography as one of the most important of the eighteenth century, very little was known about its existence. There had not been any studies based on consistent document analysis. Thus, our first goal has been to fill in a historiographical gap, dedicating part of this thesis to the study of Portuguese America's first livestock fair. To understand its functioning dynamics in a colonial context, to analyse its relationship with the process of Bahia's sertões (dryland) territorialisation through the production of cattle industry as goods and the simultaneous connection with one of South Atlantic's main seaports as well as commercial squares are all fundamental aspects to redimension the importance of livestock breeding for the reproduction of the colonial society and economy.
\end{abstract}

\section{KEY WORDS:}

Cattle fair, Capuame, livestock, dryland, supply, Bahia 
$\begin{array}{lr}\text { AGRADECIMENTOS } & 1\end{array}$

INTRODUÇÃO 2

CAPÍTULO 1: A FEIRA DE CAPUAME 4

1.1. Estabelecimento e institucionalização 8

1.2. Superintendência e vigilância $\quad 54$

1.3. Cotidiano, sociabilidade e conflito 68

CAPÍTULO 2: OS SERTÕES BAIANOS

2.1. Pecuária e territorialidade colonial $\quad 87$

2.2. As unidades produtivas 117

2.3. Sociabilidade sertaneja 139

CAPÍTULO 3: A CIDADE DE SALVADOR 159

3.1. A carne e a espacialidade de Salvador 163

3.2. Agentes mercantis: arrematadores, marchantes e contrabandistas 181

3.3. Abastecimento e motins da fome 196

$\begin{array}{ll}\text { CONSIDERAÇÕES FINAIS } & 218\end{array}$

FONTES E BIBLIOGRAFIA 220

$\begin{array}{ll}\text { Fontes Manuscritas } & 220\end{array}$

Fontes Impressas $\quad 220$

$\begin{array}{ll}\text { Bibliografia } & 221\end{array}$ 


\section{ÍNDICE DE GRÁFICOS}

Gráfico 1: Responsáveis pela condução das boiadas para Capuame (1784-1789) 26

Gráfico 2: Entrada de gado na Feira: Destino final das boiadas (1784-1789) 28

Gráfico 3: Quantidade de gado mensal (1784-1785) 30

Gráfico 4: Quantidade de gado mensal (1785-1786) 31

Gráfico 5: Quantidade de gado mensal (1786-1787) 31

Gráfico 6: Quantidade de gado mensal (1787-1788) 32

Gráfico 7: Quantidade de gado mensal (1788-1789) 32

Gráfico 8: Quantidade de gado mensal (1789-1790) 33

\section{ÍNDICE DE QUADROS}

Quadro 1: Comparação entre a quantidade de reses encaminhadas em cada mês: Safras anuais (1784-1789)

Quadro 2: Quantidade de gado em pé conduzido de Capuame à Salvador e Recôncavo (1784-1789)

Quadro 3: Origem do gado da feira de Capuame (1784-1789) 106

Quadro 4: Gado das fazendas da Administração Real (Piauî) conduzidos para Capuame - Inspeção: Santo Ignácio do Canindé (1770-1788)

Quadro 5: Gado das fazendas da Administração Real (Piau1) conduzidos para Capuame - Inspeção: São João do Piauí (1770-1788)

Quadro 6: Gado das fazendas da Administração Real (Piau1) conduzidos para Capuame - Inspeção: Nossa Senhora de Nazaré(17701788)

Quadro 7: Descrição das moradias das fazendas de gado vaccum dos sertões baianos (século XVIII)

Quadro 8: Vilas dos sertões baianos (século XVIII)

\section{ÍNDICE DE TABELAS}

Tabela 1: Etnia e condição jurídica dos trabalhadores das Fazendas da Administração Real do Piauí (década 1770)

Tabela 2: Relação entre produção pecuária e posse de escravos (século XVIII)

\section{ABREVIATURAS}

AAPB - Anais do Arquivo Público da Bahia

AHU - Arquivo Histórico Ultramarino

AMS - Arquivo Municipal de Salvador

APEB - Arquivo Público do Estado da Bahia

BN - Biblioteca Nacional

DH - Documentos Históricos da Biblioteca Nacional

RIHGB - Revista do Instituto Histórico Geográfico Brasileiro

RIGHBa - Revista do Instituto Geográfico Histórico da Bahia

RIHGMG - Revista do Instituto Histórico Geográfico de Minas Gerais 


\section{AGRADECIMENTOS}

O conhecimento é coletivo por definição. Portanto, devo muito àqueles que cruzaram o meu caminho desde o início de minha trajetória pela Universidade de São Paulo quando cismei em estudar os boiadeiros e as relações sociais forjadas pela pecuária. Sou grata a todos que acreditaram que esta pesquisa era possível. Aos pessimistas, espero ter contribuído para demonstrar a viabilidade de um trabalho sobre a feira de Capuame, independente se há lacunas ou se a escrita ficou a contento.

Agradeço ao Professor Dr. Pedro Puntoni pela confiança, liberdade e incentivo que recebo desde meu primeiro ano de graduação. À Professora Dra. Monica Duarte Dantas e Professor Dr. Istvan Jancsó, pelo apoio direto e indireto na aquisição de uma perspectiva crítica sobre a economia pecuária e a formação dos sertões baianos.

Ao professor Dr. Luiz Mott sou grata pelo apoio e a gentileza com que me recebeu em Salvador, doando importantes transcrições de documentos. À Cândido Domingues, Edison Rodrigues, Urano Andrade, Carlos Silva Junior devo as hospedagens, auxílio nos arquivos baianos e conversas sobre a Bahia de todas as contradições.

À Renata Rente, Professor Dr. Carlos Henrique Almeida Toledo, Fernão Lara, Ana Carolina Leite, Cássio Boechat e demais orientandos do Professor Dr. Heinz Dieter Heidemann agradeço pela sensação de não estar falando sozinha.

Às Professoras Doutoras Vera Lúcia Ferlini, Maria Cristina Wissenbach, Íris Kantor, Laura de Mello e Souza e Rodrigo Ricupero, pela atenção e solicitude com que sempre me receberam desde o início da graduação.

Às minhas amigas, cúmplices e interlocutoras políticas que tornaram minha vida acadêmica mais leve: Kollontai, Laura Furquim, Mariana Rocha, Carina Coelho, André Nicácio Lima, Filipe Nicoleti, Lígia Luchesi, Maria Fernanda Pinto, Bianca Coré, Juliana Bruce, Luma Prado, Flávia Uliana e demais frequentadoras dos espaços de sociabilidade que ainda restam na USP.

Ao Lincoln de Jesus Souza devo o incentivo que recebi em anos de convivência. De onde a gente veio acesso a "Universidade é um sonho distante". À minha enorme família itinerante, Maria Rita e dona Maria, devo toda a força necessária para nunca desistir mesmo em meio a situações adversas. "Eu chego lá!" 


\section{INT RODUÇÃO}

Capuame ou Capoame. Nome popular de uma árvore antes comum na região interiorana da Bahia. "Caá-poã-me: no mato em pé, no mato que se isola num campo, na mouteira ou silvado". ${ }^{1}$ Termo tupi, topônimo desaparecido, não nomeia mais lugar algum que denote vagamente a existência da primeira feira de gado na América Portuguesa localizada do século XVII até o início do século XIX em algum ponto entre os atuais municípios de Camaçari e Dias D'Avila.

Depois de transferida para Feira de Santana em 1830, Capuame caiu no esquecimento e transformou-se na Feira Velha, termo usado por alguns memorialistas e pesquisadores. Exceto algumas citações esparsas de historiadores guiados pelas poucas pistas deixadas por Antonil e Pedro Calmon somente o esforço iniciado pelo Professor Luiz Mott em Subsídios à bistória do pequeno comércio do Brasil foi no sentido de perseguir a existência de fontes primárias sobre este espaço de comercialização de gado. Até então a feira de Capuame restava no recôndito da memória coletiva como "O menos importante", aquilo que não merece ser lembrado e por desdobramento dentro de uma escala hierarquizada de valores - apresenta-se como o objeto que não se mostra digno de estudo.

Todavia, a pesquisa que agora resulta na presente dissertação de mestrado fez emergir a imagem de um espaço de relevância na capitania da Bahia do período setecentista. Feira de gado responsável pela comercialização de grande parte da produção das fazendas sertanejas dos amplos sertões baianos era o ponto obrigatório de passagem dos bovinos que alimentavam a população da cidade da Bahia de Todos os Santos, parte dos engenhos pertencentes aos membros da elite colonial e a tripulação das embarcações estacionadas no principal porto do hemisfério sul.

Sua história foi reconstruída a partir da localização de fontes primárias guardadas sobretudo nos arquivos baianos. Através do Livro de Registro de Entrada de Gado da feira de Capuame produzidos entre os anos de 1784 e 1789 foi possível perceber a constante movimentação semanal de condutores e marchantes pelos pastos e instalações da primeira e mais movimentada feira da América Portuguesa.

Tanto movimento não significa a constatação da existência de um espaço de "livre mercado", como alguns podem imaginar para as feiras nordestinas do século XIX e XX. Em Capuame estamos diante de um espaço de comércio altamente vigiado por homens de diferentes patentes e controlado pelos funcionários da Câmara Municipal de Salvador que auferiam da venda dos bovinos a maior parte de suas rendas.

1. "Vocabulário Geográfico Brasílico." Revista do Instituto Geográfico e Histórico da Babia, 1928, vol. 54, p. 228. 
Sendo assim, o objetivo desta dissertação é primeiramente preencher uma lacuna historiográfica no que diz respeito ao estudo da feira de Capuame, assim como tentar ampliar o debate sobre a dinâmica das feiras coloniais tão pouco pesquisadas, exceto Sorocaba. Tudo isso admitindo a peculiaridade da feira de Capuame enquanto espaço comercial produzido por uma sociabilidade cindida, efetivado a partir de trocas mercantis controladas e enquadradas dentro dos parâmetros de uma Economia de Antigo Regime.

Ponto de conexão entre os sertões baianos e o litoral, o percurso da dissertação tenta acompanhar essa dupla ligação que a feira de Capuame assumia. Por um lado apresentava-se enquanto um espaço de encontro de homens e mercadorias criando uma sociabilidade temporária, permitindo a comercialização de parte da produção sertaneja direcionada para o mercado. Por outro lado temos a testemunha e o desdobramento da sociabilidade urbana cindida, a "condenação dos homens às trocas"2, o ponto necessário para garantir a alimentação de uma população sempre crescente que não conseguia mais reproduzir seus meios de vida sem depender da mediação do mercado.

Sendo assim, para apresentar este mundo mediado pela mercadoria gado, a dissertação foi dividida em três partes. Cada capítulo corresponde a um espaço geográfico específico. A feira de Capuame, os sertões baianos e a cidade de Salvador.

O primeiro capítulo dedicado à Feira de Capuame trata do histórico de estabelecimento do sítio de Capuame enquanto ponto de arrebanhamento de gado vaccum em contexto de final de guerra contra os holandeses e início do recrudescimento do processo de expropriação e extermínio dos indígenas pelos práticos do sertão. A institucionalização da feira em 1727 marca uma nova dinâmica não só no espaço altamente vigiado mas também na própria produção pecuarista a qual a feira se encontrava diretamente submetida.

O segundo capítulo, Os Sertões Baianos, pretende problematizar o processo de territorialização colonial nas partes interioranas através das fazendas e a ampla produção da mercadoria gado, formando por outro lado uma sociabilidade sertaneja específica que permitia até pelo menos finais do século XVIII a formação de espaços de sombra e vivências itinerantes devido ao caráter descontínuo da ocupação das terras.

O terceiro capítulo, $A$ Cidade de Salvador, é dedicado à investigação da espacialização do comércio de carne na primeira capital e principal cidade da América Portuguesa no século XVIII. A importância do contrabando e dos agentes mercantis envolvidos em vultuoso negócio, os problemas de abastecimento, o não consumo rotineiro de carne pelos mais pobres e os motins nos momentos de carestia são alguns dos problemas levantados nesta investigação que pretende de algum modo redimensionar a importância da pecuária para a compreensão da economia e sociedade do período colonial.

2. Fernad Braudel. Civilização material, economia e capitalismo (séculos XV-XVIII), São Paulo, 1996, vol. 2 (Os jogos das trocas) p. 12 


\title{
CAPÍTULO 1: A FEIRA DE CAPUAME
}

\author{
“[...] Tudo nela é agitação, \\ e lha assinala os movimentos. \\ O ruído das feiras chega \\ distintamente a nossos ouvidos." \\ Fernand Braudel. Civilização Material, Economia e Capitalismo. Séculos XV-XVIII, São \\ Paulo, 1998, vol. 1 “O Jogo das Trocas", p. 12.

\begin{abstract}
"A alma da feira é o debate, a barganha, as discussões entre vociferações, apelos e lamúrias contra a carestia; entremeia as boas e más notícias, caras viradas às antipatias, política, namoro ... e demais expressões cotidianas desenroladas nesses espaços, independentes da localização geográfica."
\end{abstract}

Afrânio Peixoto. Livro de horas. Rio de Janeiro, 1947, p.272.

Feira de Capuame, 1806. A tentativa de assassinato do pardo André Corcino da Silva abalou o cotidiano de moradores, criadores e condutores sertanejos presentes na Freguesia de Nosso Senhor do Bonfim da Mata de São João naquela semana. Cerca de vinte pessoas apresentaram em 3 de fevereiro a queixa do crime imputado à figura do principal responsável pelo funcionamento da Feira. $O$ superintendente Antonio Xavier de Brito ${ }^{1}$ autoridade máxima do local - já era conhecido por seus desmandos que recaíam especialmente sobre os mais pobres frequentadores das tavernas "que se ocupam de jogos e outros vícios" localizadas nos arredores da feira de gado. Afirmavam ser comum o superintendente levar para o meio de matos desertos os pobres de quem almejava se livrar, além de ser temido por seu costume de dar voz de prisão em nome do governador por qualquer motivo.

Rapidamente, o superintendente apresentou uma outra versão na tentativa de se livrar da acusação: devido às desordens cometidas por certo "homem de ínfima plebe e vadio sem alguma ocupação", o mulatinho Manoel do Rego foi preso pelo cabo da polícia Bernardo Bajão e remetido à cadeia localizada na casa da superintendência da feira de Capuame. As autoridades aproveitaram a ocasião para levar preso também seu comparsa Francisco Teodósio. Os demais companheiros de vadiagem fugiram. Horas depois, tomados pela revolta, alguns amigos dos mulatos se amotinaram e foram até o local no qual estavam sendo mantidos em cárcere. Em meio ao tumulto, André Corcino da Silva, morador no sítio da Feira e amigo dos presos, foi ferido por um agressor oculto. O superintendente alegou estar do lado de

1. O superintendente era o grande responsável pela administração da feira. Nomeado pelos vereadores da Câmara Municipal de Salvador e com a provisão confirmada pelo Governador-General, suas atividades serão tratadas mais a frente neste capítulo. 
dentro da casa da superintendência no momento da confusão, mas André sobreviveu às muitas "cutiladas e bordoadas" (recebidas pelos agressores que acreditaram tê-lo deixado sem vida) e cismava em acusar (junto como outras testemunhas) o superintendente Antonio Xavier de Brito de ser o mandante do crime.

Os pobres frequentadores da Feira de Capuame não eram os únicos a alimentar antipatia pelo superintendente. Segundo ele mesmo relatou, possuía também desavenças com um marchante ${ }^{2}$. Depois de ter repreendido o negociante de gado Joaquim José de Passos $^{3}$ pela recorrência de irregularidades em seus trâmites comerciais, o marchante passou a conspirar contra a autoridade máxima da feira, forjando testemunhas, mantendo-os na freguesia de Mata de São João às suas custas, para tentar incriminar o superintendente pelo episódio da tentativa de homicídio de André Corcino da Silva. ${ }^{4}$

Os moradores responsáveis pela carta emitida ao governador da Bahia, com o propósito de denunciar os abusos da autoridade máxima da feira de Capuame, não cansavam de descrever os disparates do superintendente Antonio Xavier de Brito. Seus desmandos extrapolavam suas competências e jurisdições. Segundo as informações constantes, a feira de Capuame contava com a vigilância e ronda de dois capitães da freguesia de Mata de São João, "um miliciano do terceiro ou regimento da Torre e outro das ordenanças". Mas somente o superintendente cismava em trazer a "pobreza desinquietada com ameaças de prisões", sempre descarregando sua fúria sobre os homens ociosos que não serviam à feira e permaneciam naquele lugar por outros motivos não diretamente vinculados ao exercício de algum ofício ou trabalho. ${ }^{5}$

Mais um dado importante apareceu no depoimento dos moradores do sítio da Feira de Capuame: Antonio Xavier de Brito foi nomeado superintendente durante o governo de D. Fernando José de Portugal e Castro (marquês de Aguiar), governador e capitão-general da capitania da Bahia entre os anos de 1788 e 1801. Durante seu governo foi solicitado que o escrivão permanecesse como o responsável pela arrecadação e coleta do imposto e donativos sobre o gado em pé cobrados no registro de entrada da feira de Capuame, tamanha era a desconfiança que o Senado nutria em relação a pessoa do superintendente. ${ }^{6}$ Não se sabe ao certo porque mesmo sendo um

\footnotetext{
2. Marchante era o negociante de gado responsável por encaminhar as reses de Feira de Capuame ao matadouro público localizado em Salvador. Os detalhes sobre o trabalho exercido por este oficial mecânico e a concessão obrigatória da Câmara Municipal para atuarem neste ofício serão melhor explicadas no terceiro capítulo.

3. O marchante Joaquim José de Passos começou a aparecer como encaminhador de gado registrado e comercializado na feira de Capuame a partir do dia 15 de abril de 1789, uma semana depois da Páscoa. AMS. "Livro de Registro de Entrada de Gado" (1784-1789), fl. 219.

4. O documento foi citado inicialmente por Richard Graham. Alimentar a cidade: das vendedoras de rua à reforma liberal (Salvador, 1780-1860). São Paulo, 2013, p. 196. APEB. Câmara para o Governador, 12 de março de 1806, maço 209-1, doc. 108.

5. A perseguição aos ociosos e vadios era uma constante nos século XVIII e XIX. Para um estudo sobre à vadiagem, ver Walter Fraga Filho. Mendigos, moleques e vadios na Babia do século XIX. São Paulo/ Salvador, 1995.

6. Idem.
} 
homem pouco "honrado" continuou ocupando o cargo por tantos anos. Possivelmente era uma pessoa de confiança pessoal do governador, mas não possuía a mesma imagem compartilhada pelos funcionários municipais. Tal impasse sobre a nomeação ou continuidade da serventia no cargo poderia ocorrer, mas por tradição prevalecia a escolha do Senado da Câmara Municipal de Salvador, integralmente acatada pelo governador cujo papel resumia-se a confirmar a nomeação da Casa. Pelo visto, esse não foi o caso na escolha de Antonio Xavier de Brito, motivo de desavenças e conflitos na primeira feira de gado da América Portuguesa. ${ }^{7}$

Espaço de sociabilidade par excellence, a feira permite a efetivação das relações entre seus frequentadores e funcionários, mediadas necessariamente pelas mercadorias que dão razão de existir ao local. Conflitos devido a problemas comerciais, discussões acaloradas nas tavernas possivelmente aconteciam na mesma proporção em que laços de confiança, crédito e amizade eram estabelecidos entre criadores, condutores, marchantes, comerciantes e funcionários. ${ }^{8}$ As dívidas passivas e ativas localizadas nos livros de contas de donos de armazéns estabelecidos em Mata de São João e as informações arroladas nos inventários post-mortem de criadores e pecuaristas sertanejos nos levam a crer que as transações comerciais ocorriam, inclusive, para além da mediação da mercadoria gado e eram capazes de estabelecer e consolidar redes mercantis que extrapolavam sem dúvida os limites do espaço da feira em si, desdobrando-se e sendo perpetuadas sertões adentro.

Localizada na freguesia suburbana de Mata de São João ${ }^{9}$ - desmembrada ainda no século XVIII da primitiva freguesia de Santo Amaro do Ipitanga ${ }^{10}$ - a

\footnotetext{
7. No item deste capítulo sobre os superintendentes, será discutido o modo como os superintendentes eram nomeados. Não foi possível mapear a trajetória dos ocupantes dos cargos, sendo necessário um estudo futuro que indique quem eram estes homens e a relação com o poder local da cidade de Salvador e a região circunvizinha.

8. Citarei mais adiante exemplos das redes de créditos que foi possível mapear através dos dados localizados em inventários post-mortem de comerciantes estabelecidos nas imediações de Capuame assim como de criadores sertanejos que possuíam entre seus credores moradores da freguesia de Mata de São João

9. Devido as sucessivas mudanças nas divisões políticas e administrativas das freguesias e depois dos municípios da região a noroeste da cidade de Salvador, não havia um acordo por parte da historiografia sobre a localização da feira. Capuame foi sempre apontada como estando em algum ponto perdido entre os municípios de Dias D'Avila ou Camaçari. Muito da confusão se deve ao fato de não haver hoje em dia nenhuma referência sobre a existência da feira, nem mesmo um logradouro, exceto uma Fazenda (já desmembrada em forma de loteamento) denominada Capuame. No município de Dias D'Avila há uma estação de trem cujo nome primitivo adotado no momento de inauguração da linha ferroviária era Feira Velha, nome pelo qual a Feira de Capuame passou a ser conhecida após o ano de 1837, momento de transferência para Feira de Santana. Em 9 de julho de 1928, por sugestão de Borges de Barro e tendo Pedro Calmon como relator, a cidade de Feira Velha de Capuame passou a receber oficialmente o nome de Dias D'Avila. Sobre a transição da feira de Capuame para Feira de Santana no abastecimento do matadouro público de Salvador, ver: Rodrigo Freitas Lopes. Nos currais do matadouro público: o abastecimento de carne verde em Salvador no século XIX (1830-1873). Salvador, UFBA, dissertação de mestrado, 2009. Sobre a mudança de nome ver: $A A P B$, Salvador, v. 24, p.45.

10. A feira de Capuame aparece como termo da freguesia de Santo Amaro de Ipitanga pelo menos até 1732. Luiz Mott. "Subsídios à história do pequeno comércio no Brasil". Revista de História, vol. 53, n. $105(1976)$
} 
Feira de Capuame ficavam distante oito léguas da cidade de Salvador da Bahia de Todos os Santos. ${ }^{11}$ Entre os rios Jacuípe e Joannes, em suas extensas invernadas e pastos, cercada por aguadas capazes de abrigar simultaneamente um número considerável de boiadas, aconteciam todas as quartas-feiras o comércio do gado vindo das mais distintas partes dos sertões baianos. Muitos homens conduzindo gado próprio ou alheio enfrentavam centenas de léguas até chegarem ao local da venda dos animais. Havia uma grande presença de boiadas vindas dos sertões do Piauí, ${ }^{12}$ distante cerca de duzentas e cinquenta léguas da feira de Capuame, demonstrando assim as enormes distâncias percorridas em direção a mais movimentada feira de gado do período colonial.

Responsável pelo abastecimento da primeira capital da América Portuguesa, e depois um dos mais significativos portos e cidades do hemisfério sul; apontada frequentemente como uma das primeiras feiras de gado da colônia, citada pela maior parte dos pesquisadores dedicados à História da Bahia, sertões ou pecuária ${ }^{13}$, Capuame era o espaço articulador e intermediário entre os sertões baianos e a cidade da Bahia de Todos os Santos. Teve papel fundamental para a vitória das tropas brasileiras comandadas pelo francês Pierre Labatut no momento da guerra de Independência em 18221823 quando a cidade foi cercada, impedindo o fornecimento dos víveres às tropas portuguesas que logo capitularam. ${ }^{14}$

A feira é por princípio a testemunha do processo de divisão social do trabalho, "da condenação dos homens à troca"15, da cisão entre a grande lavoura produtora de gêneros de exportação e a produção de alimentos voltados para o abastecimento interno, garantidora da reprodução dos meios de vida da população já muitas vezes despossuída de suas terras e da possibilidade de produzirem para si.

Ponto de encontro entre realidades e experiências de homens vindos de mundos distintos; espaço intermediário entre produtores e consumidores; sempre caracterizada pelo movimento, pelo seu barulho e agitação. Sítio de parada de viandantes, andarilhos, mascates. Abrigava a constante oferta dos produtos carregados pelas escravas de ganho, os trabalhos prontamente oferecidos por seleiros, ferreiros e sapateiros e os serviços e carinhos prestados pelas prostitutas. Rodeado de aguadas, pastos, currais, pousos, estalagens e

\footnotetext{
11. André João Antonil. Cultura e Opulência do Brasil por suas drogas e minas. Introdução e notas de Andrée Mansuy Diniz Silva, São Paulo, 2007, p. 296.

12. O levantamento estatístico das áreas produtoras que mais abasteciam a Feira de Capuame será analisado no decorrer do segundo capítulo.

13. Stuart Schwartz. Segredos Internos. São Paulo, 1999. p. 88; Jacob Gorender. O escravismo Colonial. São Paulo, 1988, p. 44; Luis Felipe de Alencastro. Trato dos Viventes. São Paulo, 2000, p. 340; RussellWood. Fidalgos and philantropists. Berkley, 1968, p. 60, 264,410; Russell-Wood. Society and Government, 1992. p. 38; Richard Graham. Alimentar a cidade: das vendedoras de rua à reforma liberal (Salvador, 17801860), São Paulo, 2013, p. 169 e segs; Luiz Mott. "Subsídios à história do pequeno comércio no Brasil". Revista de História, vol. 53, n. 105 (1976); Maria Yedda Linhares. História do Abastecimento. Brasília, 1979, p. 47.

14. Richard Graham. op. cit. p. 224.

15. Fernand Braudel, Civilização material, economia, capitalismo (séculos XV-XVIII), São Paulo, 2009, vol. 2 (Os jogos das trocas), p. 12.
} 
tavernas, permitia a construção de espaços provisórios de convivência social. Ponto simultaneamente marcado pela espera dos produtores ou condutores de gado sedentos em ver um fim para as suas longas jornadas, ansiosos por fechar um bom negócio, abrigava ao mesmo tempo a circulação e os olhos atentos dos espertos marchantes, já versados nos negócios de gado, sempre a espera por uma oportunidade de comprarem pelo menor preço possível as reses sertanejas.

Espaço marcado por um ritmo mais acelerado, se comparado aquele comum às sociedades rurais, forjado pela quebra temporária do cotidiano, pela constante circulação de todo o tipo de gente das mais distintas condições sociais, vindas dos lugares mais díspares possíveis. Velha conhecida dos povos africanos, a feira em Kimbundo (língua falada no reino de Ndongo) era chamada de kitanda ${ }^{16}$, que por sua vez dá nome no Brasil ao tipo de espaço no qual se costuma comercializar especificamente frutas e hortaliças. ${ }^{17}$ Suas características, assim como sua origem etimológica, lembram as festas e celebrações religiosas do Antigo e Novo Mundo. ${ }^{18}$ Assim possivelmente era a feira de Capuame e seus agitados arredores sempre muito movimentados pela constante presença de criadores, condutores e tangedores de gado sertanejo, marchantes e escravos auxiliares dos negociantes, militares e funcionários régios. Sua história nos remete à segunda metade do século XVII.

\subsection{Estabelecimento e institucionalização}

O sítio de Capuame foi escolhido na segunda metade do século XVII pelo governador general, vereadores e alguns moradores ilustres para ser o ponto oficial de arrebanhamento do gado criado nas paragens interioranas da capitania da Bahia destinado a recompor as finanças e o abastecimento no momento pós-guerra contra os neerlandeses. ${ }^{19}$ Localizado em um espaço relativamente próximo à cidade de Salvador, em terras do Conselho Municipal ${ }^{20}$, vizinho da protegida região da Torre de Tatuapara ${ }^{21}$, era

16. Mariana Bracks Fonseca. Nqinga Mbandi e as guerras de resistência em Angola. Século XVII. São Paulo,USP, 2012, p. 95

17. Nei Lopes. Enciclopédia Brasileira da Diáspora Africana. São Paulo, 2004. p. 554.

18. Dulce Maria Pamplona Guimarães. A celebração da modernidade: a feira e a festa nas exposições agropecuárias do nordeste paulista. USP, São Paulo, 1996.

19. Segundo a resolução, nenhum privilegiado receberia isenção da nova finta que se resumia ao arrebanhamento de 1.000 cabeças de gado para serem enviada tanto para Salvador quanto para Pernambuco visando à recuperação das finanças em um contexto pós-guerra. Diversos funcionários e militares foram nomeados para promover o recolhimento dos bovinos que abundavam nas paragens interioranas. Várias reses também foram confiscadas daqueles que auxiliaram de algum modo os holandeses. AMS. Atas da Câmara (1649-1659), volume 3, 24 de maio de 1651, p. 142; idem, "Cópia da carta do Mestre de Campo General deste Estado." 26 de maio de 1651, p. 144; 26 de maio de 1651, p. 148. DH. "Ordem para o Sargento-maior Balthazar dos Reis Barrenho ir listas todos os gados que há do distrito da Vigia até a Torre". 16 de novembro de 1654. vol. 4, p.177.

20. Segundo documentos da Câmara Municipal de Salvador, as terras em Itapuã e na freguesia de Santo Amaro do Ipitanga pertenciam ao Conselho Municipal. Sendo assim, era necessário aos seus ocupantes pagar foro pelo uso da área. AMS. "Termo de vereação". Atas da Câmara (1700-1718). 1 de outubro de 1701 , vol. 7 , p. 83 
considerado um ponto estratégico, seguro e conveniente para garantir o constante suprimento de gado vaccum tão necessário à alimentação de tropas, funcionários régios, moradores e tripulação das Naus e embarcações sempre aportadas no cais da primeira capital da América Portuguesa. ${ }^{22}$

Em um contexto marcado sobretudo por um período de rearranjo da política colonial post-bellum, os esforços mobilizados inicialmente para enfrentar os inimigos externos ${ }^{23}$ foram paulatinamente convertidos no sentido de garantir a estabilidade interna e viabilizar a expansão das fronteiras e o avanço da ocupação lusitana rumo ao sertão. ${ }^{24}$ Seja através das entradas em busca de metais preciosos ${ }^{25}$, no movimento de apresamento de índios para abastecer de mão-de-obra os engenhos de cana-de-açúcar do Recôncavo Baiano (diante da crise do tráfico negreiro devido a intervenção da Companhia das Índias Orientais em Angola) ${ }^{26}$, ou ainda, seguindo no encalço dos missionários sedentos em propagar a fé cristã em contexto de Contra-Reforma, a segunda metade do século XVII foi palco de uma tentativa de maior reconhecimento e consolidação do domínio português sobre o vasto território. ${ }^{27}$

Todavia, as entradas rumo ao interior não ocorreram de forma tranquila. A quebra de soberania indígena sobre a região recém-conquistadas se deu às

21. Para uma perspectiva crítica sobre a família formadora da Casa da Torre, ver: Angelo Emílio da Silva Pessoa. As ruinas da tradição: a casa da Torre de Garcia D'Ávila - família e propriedade no nordeste colonial, São Paulo, USP, 2003.

22. Vários são os autores que ressaltam a importância da pecuária para ocupação e exploração do território, além de alimento básico para a maior parte dos moradores da América Portuguesa. Capistrano de Abreu. Capitulos de História colonial \& Os caminhos antigos e povoamento do Brasil. [1907]. Brasília, 1982; Caio Prado Junior. Formação do Brasil Contemporâneo. [1942] São Paulo. Charles Boxer. A Idade de ouro do Brasil (Dores de Crescimento de uma Sociedade Colonial). São Paulo, 1963, p. 201; Celso Furtado. Formação Econômica do Brasil. São Paulo, 1982, p. 57.

23. Sobre a tomadia do gado dos moradores da capitania da Bahia para o sustento da Infantaria e o socorro dos soldados que enfrentavam os holandeses, ver: AMS. Cartas Do Senado (1638-1673) "Termo de vereação de 13 de novembro de 1640", volume 1, p. 8.

24. Parte do valor arrecadado com a nova finta sobre o gado criado na capitania da Bahia foi convertido no financiamento das "Jornadas do sertão". AMS. Atas da Câmara (1649-1659), vol. 3. "Termo que se fez sobre a Jornada do Sertão e os lançamentos das fintas.", p. 167. Devido ao esforço concentrado para por fim às disputas com os holandeses, as investidas contra os indígenas foram proteladas até o final da guerra holandesa. "Assento tomado na Relação da Bahia sobre a guerra aos índios selvagens, extraído do livro 4o. de Ordens Régias ao governador e capitão-general do Brasil, no ano de 1694 a 1695”, 04/03/1669. RIHGB, Rio de Janeiro, v. 6, p. 391-398, 1865. p. 393. Ou [Assento], 04/03/1669. In: Ignácio Accioli de Cerqueira e Silva. Memórias históricas e políticas da Província da Bahia. Bahia : Imprensa Oficial do Estado, 1925. v. 2. p. 30-33.

25. Memória e documentos selecionados por Francisco Adolpho Varnhagen. Ver: Francisco Adolpho Varnhagen. "Gabriel de Soares de Sousa: Memória." Revista do Instituto Histórico e Geográfico Brasileiro, 1858, vol. 21, p. 494.

26. Segundo Sérgio Buarque de Hollanda, a busca de metais preciosos servia muito mais como justificativa dos senhores de engenho para adentrarem no território e promoverem o apresamento dos autóctones. Sérgio Buarque Hollanda. "Pedras e peças". Visão do Paraíso: os motivos edênicos no descobrimento e colonização do Brasil. São Paulo, 1996. Sobre o momento de desestruturação do tráfico negreiro devido às investidas holandesas em Angola,ver: Wolfgang Lenk. Guerra e Pacto Colonial: exército, fiscalidade e administração colonial na Babia (1624-1654). Campinas, 2009.

27. Monica Dantas. "Povoamento e ocupação do sertão de dentro baiano (Itapicuru, 1549-1822)". Penélope, Oeiras, v.23, 2000, pp.9-30 ; Fabrício Lyrio Santos. Da catequese à colonização. Colonização e povos indígenas na Babia (1750-1800), UFBA, Salvador, 2012; Pe. Martinho de Nantes. Relação de uma missão na rio São Francisco. São Paulo, 1979 
custas de muito conflito, derramamento de sangue e enfrentamento, contando com a resistência e o constante ataque dos autóctones tendo por alvo principal as fazendas e engenhos estabelecidos na região do Recôncavo Baiano, abrindo as brechas necessárias para a deflagração da "guerra dos Bárbaros". ${ }^{28}$ Efetivado pelos "práticos dos sertões" - possuidores de patentes militares e experiência bélica comprovada nos conflitos contra os holandeses; habilidosos no apresamento e homicídio de índios contrários à ocupação portuguesa e captura de negros fugidos e aquilombados - o movimento de alargamento das fronteiras lusitanas no Novo Mundo acirrava os ânimos dos autóctones que se viam forçados ao deslocamento constante para não serem escravizados, aldeados ou exterminados. ${ }^{29} \mathrm{O}$ ciclo vicioso iniciado com o movimento de interiorização e os desdobramentos da guerra contra diversas comunidades indígenas - entendidas genericamente como tapuias - concretizava as condições básicas para a territorialização coloniaß ${ }^{30}$ através do desimpedimento da expansão europeia pela hinterlândia.

Os participantes mais destacados das "jornadas do sertão"31 receberam terras como forma de retribuição pelo serviço prestado ${ }^{32}$ e estabeleceram fazendas de gado vaccum na medida em que não bastava somente impor o avanço das tropas que se embrenhavam em nome da Coroa portuguesa pelas matas desconhecidas; era necessário realizar o domínio e a soberania através da ocupação permanente e da conversão das terras em espaços produtores de mercadorias. ${ }^{33} \mathrm{E}$ para tal finalidade nada mais conveniente do que a criação de

28. Pedro Puntoni. A Guerra dos Bárbaros: povos indigenas e a colonização do sertão nordeste do Brasil, 16501720. São Paulo, 2002 ; Juliana Brainer Barroso Neves. Colonização e resistência no Paraguaçu - Babia, 1530-1678. UFBA, Salvador, 2008.

29. Os povos indígenas estabelecidos no interior tinham por princípio a vida nômade, no entanto, com a chegada dos europeu o deslocamento forçado adquiriu uma outra lógica, tendo um impacto profundo na vida das comunidades autóctones. Jaime Cortesão. Raposo Tavares e a Formação Territorial do Brasil. Lisboa, Portugália, 1966.

30. "Processo compreendido como a reorganização de determinada realidade espacial, cujo sentido é definido pela generalização de relações sociais de produção voltadas para possibilitar a acumulação de capital. Territorialização, portanto, é a produção do território do capital. " Ana Carolina Gonçalves Leite. A moderniz̧ação do V ale do Jequitinhonha mineiro e o processo de formação do trabalhador "bóia-fria" em suas condições regionais de mobilização do trabalho, USP, São Paulo, 2010. p. 16.

31. Expedições oficiais nomeadas pelas autoridades régias para desembaraçar as terras interioranas da presença de indígenas. Pedro Puntoni. op. cit., p. 91 e segs.

32. Sobre a política de concessão de terras e patentes no período colonial, ver: Rodrigo Ricupero. $A$ formação da elite colonial: c.1530 - c. 1630. São Paulo: Alameda, 2008. Sobre as “jornadas do sertão", ver: Pedro Puntoni. A guerra dos Bárbaros, São Paulo, 2002; DH. Rio de Janeiro, Biblioteca Nacional. vol. 7 p. 395; vol. 9, p. 37; vol. 11, p. 403; vol. 8, p. 385; vol. 7 , p. 77; vol. 7 p. 70; DH. "Alvará de confirmação de umas datas (de) terras do sargento-mor Francisco Lopes ira Capitania do Rio Grande e por que se lhe dão de novo as sobras de outras que houver na vargem de Mopubú". vol. 24, p. 50; DH. "Registo da patente do Mestre de Campo de um dos terços de Infantaria desta praça Antonio Quedes de Brito", vol. 24, p. 99 ; DH. "Registo de uma carta de doação e sesmaria que na Capitania do Rio Grande se deu ao Sargento-mor Pedro da Silva Cardoso Miguel Rodrigues Valcacer, e Antonio da Silva Cardoso de quinze léguas de terra." vol. 24, p. 110; DH. "Registo da patente do Sargentomaior Francisco de Brá". vol. 24, p. 208; DH. "Registo da patente do Capitão Luiz Cardoso provido na companhia de Francisco Telles". vol. 24, p. 236.

33. Carl Schmitt. "La toma de la tierra em un Nuevo Mundo." El Nomos de la Tierra: em el derecho de gentes del "Ius publicum europaeum". Madrid, 1979. Sobre uma releitura crítica do conceito de soberania a partir da análise de Carl Schimtt, ver Giorgio Agamben. "Lógica da Soberania". Homo sacer: o poder soberano e a vida nua I. Belo Horizonte, 2002. 
gado vaccum, consolidando uma ocupação extensiva e relativamente rápida, convertendo vasto território antes habitado por indígenas em unidades esparsas de exploração econômica, ${ }^{34}$ além de servirem como ponto de apoio para as tropas em seu constante movimento pelos sertões.

O serviço militar é um dos exemplos de especialização do trabalho e aumento da necessidade de produção alienada, na medida em que os combatentes são obrigados a dedicarem-se exclusivamente às investidas bélicas e manterem-se em permanente deslocamento no auge da guerra, sobrando pouco tempo para a produção das próprias condições básicas de reprodução diária. ${ }^{35}$ No século XVII e início do século XVIII, várias eram as solicitações de "munição de boca" para alimentar os destacamentos militares. ${ }^{36}$ Os produtos vinham das fazendas já consolidadas que tinham por razão de ser a obrigação de fornecer a carne e farinha de mandioca necessária aos combatentes. Auxiliar os esforços de guerra em suas manobras e facilitar o abastecimento era uma dos deveres dos súditos estabelecidos no interior da colônia. ${ }^{37}$ Vale lembrar que muitos dos primeiros sistemas de tributação dos Estados Modernos tinham por função garantir e manter sempre em prontidão as tropas e os destacamentos militares ainda não profissionalizados em caso de necessidade ou deflagração de algum conflito sempre na eminência de ocorrer tendo em vista o caráter expansionista e beligerante dos impérios europeus. ${ }^{38}$

Fonte de proteína, a carne verde - ou carne fresca - estava dentre os gêneros comestíveis mais consumidos pela população colonial. $\mathrm{O}$ costume de ingerir carne de vaca foi adquirido da metrópole portuguesa, experiente que era na criação do gado vaccum produzido em quantidade significativa na Península Ibérica. ${ }^{39}$ De lá, vieram as primeiras reses formadoras dos extensos rebanhos das colônias. Misturados às raças de bovinos vindos de África e

34. "Roteiro do Maranhão a Goiaz pela Capitania do Piauhi," [177-]. RIHGB, Rio de Janeiro, v. LXII, p. $60-161,1900$, p 88.

35. Vários são os exemplos de cobrança de impostos e necessidade de aumento de produção de regiões inteiras para abastecer (compulsoriamente ou não) tropas e forças militares na Idade Moderna. Charles Tilly. Coerção, Capital e Estados Europeus. São Paulo, 1996.

36. DH. "Regimento que levou o Sargento-mor Pedro Gomes para abrir a estrada desde a Cachoeira té o Orobó". Bahia, 3 de outubro de 1657. p. 49-54. vol. 4 ; DH. "Regimento que levou o Capitão Bartholomeu Aires, que foi por Cabo de quatro Companhias fazer guerra ao Gentio do Sertão ." p. 64, vol. 4 ; DH. "Portaria que se passou aos officiais da Camara para dar três mezes de soccorro ao Ajudante Manuel Fernandes Ferreira e a cinco soldados que leva consigo." 16 de setembro de 1672. p. 109 vol . 8.

37. Segundo termo de vereação do dia 11 de março de 1653 os criadores presentes na Câmara obrigaram-se a dar "a vintena dos gados que tiverem de três anos pra cima pelos preços em que se consertarem ajudando lhes a por fora dos seus pastos com a sua gente". AMS. Atas da Câmara (16491659). vol. 3 , p. 237 ;DH. "Portaria que se passou ao Sargento Pedro Gomes para tomar o gado necessário para o sustento da gente do sertão. ” 16 de Outubro de 1657. p. 56 ;DH. “Assento que se faz de como Agostinha de Medeiros há de cobrar cada anno pela folha do assentamento desta Capitania cem mil réis por conta de quatrocentos quatorze mil quatrocentos e dous réis que monta um mandado do Conde General Antonio Telle de dezessete de setembro de seiscentos quarenta e nove no qual vão incluídos outros que fazem a dita quantia que são de gado.” 12 de dezembro de 1659. vol. 20, p. 135-136; DH. "Portaria que levou capitão-mor Brás Roiz de Arzão" 9 de maio de 1673

38. Charles Tilly. op. cit; Geoffrey Parker. El ejército de Flandes y el Camino Español (1567-1659): La logística de la vitoria y derrota de España en las guerras de los Países Bajos. Madrid, 1985.

39. Jorge Gaspar. As feiras de gado da Beira Litoral. Lisboa, 1986. 
Índia, formaram espécies mestiças, tais como o gado criolo, curraleiro e os extintos Gudimar e Malabar. ${ }^{40}$ Ao lado da farinha de mandioca, feijão e milho, a carne figurava como um dos alimentos que deixaram marcas indeléveis na composição do cotidiano e na espacialidade da América Portuguesa, para não citar por ora a multiplicidade de experiências em outras áreas do Novo Mundo relacionadas à produção voltada para o abastecimento interno. ${ }^{41}$

Fora o consumo do gado como alimento em forma de carne fresca ou carne seca ${ }^{42}$, os bois mansos eram utilizados largamente como força motriz nos século XVII e XVIII. Muitos dos engenhos de cana possuíam maquinário operado com auxílio de tração animal. O próprio transporte da cana recémcortada, em direção às moendas, era feito por carreiros livres ou escravos conduzindo carros de boi. Depois do preparo do açúcar, as pesadas caixas do "ouro branco", também seguiam em carros puxados por bois mansos em direção aos trapiches e embarcações. ${ }^{43} \mathrm{O}$ tabaco e até mesmo as toras de madeira Del Rey (retiradas das matas das vilas e freguesias do litoral sul das Capitanias da Bahia, Ilhéus e Porto Seguro para fabricar os mais variados tipos de embarcações) eram transportadas por numerosas juntas de bois mansos vindos diretamente dos sertões próximos aos rios Jequié e Jequiriçá. ${ }^{44}$ Todo o tabaco exportado seguia embalado por tiras de couro que protegiam e conservavam o fumo comercializado largamente em África e Europa. ${ }^{45}$

Para uma sociedade cada vez mais pautada pela divisão e especialização do trabalho, com regiões dedicadas crescentemente à produção de mercadorias voltadas para a exportação ${ }^{46}$, o espaço destinado à criação de gado perto do litoral tornava-se cada vez mais raro na medida em que as terras produtivas e mais próximas da região portuária eram convertidas sempre que possível para

40. Manuel Correira de Andrade. Áreas de dominio da pecuária extensiva e semi-intensiva na Babia e Norte de Minas Gerais. Recife, 1982, p. 223.

41. As ilhas de Cuba e Jamaica eram inicialmente dedicadas majoritariamente a produção de alimentos para abastecer as colônias europeias no Novo Mundo. O inteiro dos Estados Unidos, assim como muitas das possessões espanholas ( em especial as Províncias da região platina), foram ocupadas originalmente pela pecuária, ainda presente em muitas localidades. Sobre a pecuária na Jamaica, baseado especialmente nos diários produzidos por um vaqueiro, ver: Douglas Hall. In Miserable Slavery: Thomas Thistlewood in Jamaica, 1750-86. London, 1989 e Trevor Burnard. "The sexual life of an Eighteenth-Century Jamaican Slave Overseer." Mastery, Tyranny, and Desire: Thomas Thistlewood and His Slaves in the Anglo-Jamaican World, 2004.

42. Segundo Leonardo Rolim, o termo charque tem origem quechua e não era conhecido e muito menos utilizado pelos habitantes das capitanias do Centro e Norte da colônia. Leonardo Cândido Rolim. "Tempo das carnes" no Siara Grande: dinâmica social, produção e comércio de carnes secas na Vila de Santa Cruz do Aracati. (c.1690-c. 1802), João Pessoa, UFPB, 2012.

43. Antonio Gomes Ferrão Castelo Branco. Borrador em que lanço todas as cartas que escrevo, principiado em agosto de 1742, estando na Babia. São Paulo, Coleção Mindlin. Transcrito por Rosana Gonçalves sob orientação da Profa DrMary Del Priore e gentilmente cedido pelo Prof. Dr. István Jancsó , fl. 42 v, 53, 77 e segs.

44. APEB. Correspondência expedida pelo governador da Bahia. Sargento-mor de Jequiriça, Una e Estiva (1779-1780). Seção do Arquivo Colonial e Provincial. Maço 201-20.

45. Gustavo Acioli Lopes. Negócio da Costa da Mina e Comércio Atlântico. Tabaco, Açúcar, Ouro e Tráfico de Escravos: Pernambuco (1654-1760). USP, São Paulo, 2008.

46. Caio Prado Junior. Formação do Brasil Contemporâneo. São Paulo, 1986, p. 187; Celso Furtado. Formação Econômica do Brasil. São Paulo, 1982. p. 57. Fernado Antonio Novais. Portugal e Brasil na Crise do Antigo Sistema Colonial (1777-1808). São Paulo, 2001, p. 71. 
o plantio de cana-de-açúcar, seguido pela mandioca e o tabaco. ${ }^{47}$ Culturas predominantes na região do Recôncavo Baiano, várias foram as disputas e as diretrizes das autoridades régias para afastar sistematicamente a produção pecuarista, empurrando-a cada vez mais para os sertões da Capitania da Bahia e adjacentes. ${ }^{48}$

Desta maneira, a criação de gado assumiu simultaneamente dois papéis fundamentais para a configuração espacial da América Portuguesa e em especial da Capitania da Bahia e suas vizinhas. Serviu como fator inquestionável de rápida territorialização colonial ${ }^{49}$ após o extermínio dos indígenas (já que as áreas devastadas deviam se converter em posses portuguesas para garantir o domínio sobre a região recém-conquistada), ${ }^{50}$ além de tornar o interior da colônia economicamente produtivo segundo as diretrizes impostas para a confirmação das sesmarias doadas pela Coroa $^{51}$ (na medida em que outros tipos de atividades agrícolas, quando voltadas para a exportação, mostravam-se impraticáveis devido à distância significativa da área produtora em relação ao porto de embarque da mercadoria). ${ }^{52}$

Quando a produção agrícola era direcionada ao mercado, a distância em relação ao centro consumidor tendia a ser um fator que limitava o cultivo pois não só os produtores teriam de arcar com os custos onerosos de transporte e mão-de-obra, como também corriam o risco de perder a safra devido ao tempo necessário para encaminhá-la aos centros consumidores. Para o gado, a distância não era um problema. Mercadoria semovente, auto transportável, enfrentava semanas ou meses de viagem, percorrendo centenas de léguas,

47. Barickman. Um contraponto baiano: açúcar, fumo, mandioca e escravidão no Recôncavo, 1780-1860. Rio de Janeiro, 2003.

48. Várias foram as medidas datadas de 1701 que requeriam o afastamento da atividade criatória do Recôncavo baiano. Era estipulado uma distância de 10 léguas em relação ao litoral para o estabelecimento de fazendas de gado. As inúmeras reedições do Alvará significa possivelmente o insistente descumprimento da medida. Vários foram os conflitos entre vizinhos deflagrados pela entrada dos bovinos em terras dedicadas ao cultivo de mandioca e outros gêneros agrícolas, causando destruição de parte da safra. $D H$, “Alvará régio suscitado a observância da lei de 15 de fevereiro de 1688 obrigando os habitantes da Capitania da Bahia à plantação de mandioca” 27 de fevereiro de 1701, vol. 31, p. 90-91.

49. Ana Carolina Leite, op. cit.

50. A facilidade com que se montava uma fazenda de gado no período colonial foi documentada pelo "Roteiro do Maranhão" através da célebre frase "Levantada uma casa coberta pela maior parte de palha, feitos uns currais e introduzidos os gados, estão povoados três léguas de terra e estabelecida uma fazenda", reproduzida por muitos estudiosos que entenderam a importância do assunto para pensar a formação do Brasil e a ocupação territorial da maior parte das terras sob domínio português. Maria do Socorro Coelho Cabral. Caminhos do gado: conquista e ocupação do sul do Maranbão. SIOGE, São Luís, 1992, p. 106; Capistrano de Abreu. Capitulos da História do Brasil Colonial (1500-1800) \& Caminhos de Povamento. Brasília, 1963, p. 145 entre outros.

51. Sesmaria era uma regime de doação de terra estabelecido pela Coroa Portuguesa no sentido de assegurar a ocupação, defesa e produção do território que a pertencia. Marcia Maria Menendes Motta. "Sesmeiros e posseiros nas malhas da lei." Nas Fronteiras do poder: conflitos de terra e direito agrário no Brasil de meados do século XIX. Unicamp, Campinas, 1996. p. 150 e segs. ; Felisbelo Freire. História Territorial do Brasil: Babia, Sergipe e Espirito Santo. Rio de Janeiro, 1906.

52. Monica Dantas. "Povoamento e ocupação do sertão de dentro baiano (Itapicuru, 1549-1822)". Penélope, Oeiras, v.23, 2000, pp.9-30; Maria Yedda Leite Linhares. "A pecuária e a produção de alimentos na colônia”. Tamás Szmrecsányi (org.) História Econômica do Período Colonial. São Paulo, 2002, p. 117. 
acompanhada por uma quantidade significativa de condutores e tangedores. Depois das longas jornadas, novamente consegue-se entender a importância do sítio de Capuame; seus pastos e invernadas possibilitavam a recuperação do rebanho fatigado, além de viabilizar a engorda dos animais antes de chegarem aos centros consumidores.

O aumento da população litorânea da capital colonial, ${ }^{53}$ a necessidade de abastecimento de embarcações e das Naus das Índias ${ }^{54}$ estacionadas no principal porto do Atlântico Sul, ${ }^{55}$ além da crescente demanda por abastecimento das tropas e expedições militares envolvidas com a guerra dos Bárbaros, tornou o gado espalhado pelas mais distintas paragens dos sertões baianos próximos ao rio São Francisco (produzido de forma extensiva e a solta) cada vez mais requisitado. ${ }^{56}$

Sendo assim, para facilitar a vida dos homens de patente que tinham de percorrer os sertões afora confiscando gado o mais rápido possível nos momentos de falta de carne, ${ }^{57}$ Capuame foi eleito o ponto no qual os funcionários régios deveriam manter concentrado o maior número de boiadas possível para dinamizar o abastecimento do centro econômico, político e administrativo da América Portuguesa.

Entre os rios Joanes e Jacuípe, relativamente próximo à cidade de Salvador e a um dos principais portos do Atlântico Sul, o sítio de Capuame era

53. São vários os cálculos aproximativos que demonstram o crescimento substantivo da população da cidade de Salvador, Recôncavo e a capitania da Bahia no decorrer do século XVIII. Ver: Avanete Pereira Sousa. Poder local, cidade e atividades econômicas ( Babia, século XVIII). USP, São Paulo, 2003, p. 32; B. J. Barickman. Um contraponto baiano: açúcar, mandioca e escravidão no Recôncavo, 1780-1860. Rio de Janeiro, 2003, p. 38 e 45; Maria Aparecida Silva de Sousa. Babia: da capitania à provincia, 1808-1823. USP, São Paulo, 2008, p. 46.

54. DH. "Carta de 8 de julho de 1651", vol.3, p. 123-125 e "Ordem para o Sargento-maior Balthazar dos Reis Barrenho ir listas todos os gados que há do distrito da Vigia até a Torre". 16 de novembro de 1654. vol. 4, p.177. DH. "Carta para o juiz de fora desta cidade sobre o gado para o açougue." 3 de setembro de 1723, vol. 87, p. 188; DH. "Carta que se escreveu ao Desembargador José de Sá, Antônio da Silva Pimentel, Garcia de Ávila, Domingos Afonso Sertão, e ao Doutor André Leilão de Melo, sobre mandarem vir gados das suas fazendas, que se lhes segura o preço de cruzado enquanto estiver aqui a frota." 12 de setembro de 1705 vol. 41 , p. 128;DH. "Carta que se escreveu ao Capilão-mor Baltasar Vanhique, e ao Capitão João de Seixas Ferraz para fazerem vir todas as boiadas, que àquele distrito da Água Fria chegarem, para esta cidade. " 18 de setembro de 1705. vol. 41, p. 131. Sobre as Naus das Índias ver: José Roberto do Amaral Lapa. A Babia e a Carreira da Índia. São Paulo, 2000.

55. Richard Graham. op. cit.

56. A região do sertão de dentro - leia-se Itapicuru, Inhambupe, até o rio São Francisco, subindo para a região de Joazeiro - foi o primeiro espaço a ser efetivamente ocupado por fazendas de gado dispersas conforme os índios contrário a presença portuguesa foram sendo reduzidos ou exterminados. Monica Dantas, op. cit. e Felisbelo Freire. História Territorial do Brasil: Babia, Sergipe e Espirito Santo. Rio de Janeiro, 1906.

57. Sobre a autorização dada à vários militares para confiscarem o gado necessário à alimentação das tropas. Ver entre outras referências: DH. "Carta que se escreveu ao Desembargador José de Sá, Antônio da Silva Pimentel, Garcia de Ávila, Domingos Afonso Sertão, e ao Doutor André Leilão de Melo, sobre mandarem vir gados das suas fazendas, que se lhes segura o preço de cruzado enquanto estiver aqui a frota." 12 de setembro de 1705 vol. 41 , p. 128; DH. "Carta que se escreveu ao Capitãomor Baltasar Vanhique, e ao Capitão João de Seixas Ferraz para fazerem vir todas as boiadas, que àquele distrito da Água Fria chegarem, para esta cidade. ” 18 de setembro de 1705. vol. 41, p. 131. 
formado por um terreno arenoso, com poucos acidentes geográficos e muitas aguadas; composição ideal para a permanência do gado vaccum. Possuidor de grandes invernadas, cortado por rios perenes, mostrou-se um excelente e estratégico espaço capaz de receber um número significativo de boiadas que podiam ficar "empastouradas" 58 com facilidade até serem encaminhadas para a capital ou Recôncavo Baiano no momento mais propício para o abate e consumo.

$\mathrm{Na}$ ocasião da escolha do sítio de Capuame enquanto ponto oficial para arrebanhamento das boiadas, foi decidido pela reabertura e melhoria do caminho da Mata de São João para facilitar o transporte dos bovinos. Antes das obras de aprimoramento, a região era percorrida usando uma estrada que passava pela Torre de Tatuapara. Entretanto, além de ser coberta por muitas pedras e maus pastos, ampliava o tempo de viagem obrigando o transeunte a dar uma volta desnecessária antes de seguir pelo rumo mais cômodo até a cidade de Salvador. A construção ficou a cargo do capitão João Lobo de Mesquita, visto a estrada cortar sua fazenda chamada Jacuípe, possivelmente na altura do rio homônimo. Tinha o direito de cobrar uma quantia de $5 \$ 000$ réis de cada um dos currais que houvesse até as bandas do rio São Francisco para viabilizar a empreitada. ${ }^{59} \mathrm{O}$ historiador Angelo Emílio Pessoa, em Ruinas da Tradição, lembra que a medida certamente trouxe em descontentamento o senhor da Torre de Tatuapara, o sertanista Dias D'Avila, grande beneficiado com o tortuoso caminho antigo da Mata de São João. ${ }^{60} \mathrm{O}$ pedido de construção de uma ponte sobre o rio Joannes naquela mesma estrada anos depois visava a melhoria das condições de encaminhamento das inúmeras boiadas destinadas a abastecer a capital da colônia no sentido de racionalizar e tornar mais breve o trajeto da mercadoria semovente. ${ }^{61}$

Segundo o vigário da igreja matriz de Santo Amaro de Ipitanga, João Rodrigues de Figueiredo, a freguesia em que estava localizado o sítio de Capuame era cortada por vários rios (Joanes, Pojuca e Jacuípe) em que não se passava a pé ou a cavalo, se não de canoa ou jangada. Para a travessia era necessário pagar ao contratador da passagem Real um valor determinado. $O$ vigário alegava que recebendo 50 mil réis de côngrua, tornava-se inviável

58. O termo aparece frequentemente na documentação produzida pela Camara Municipal de Salvador e pelo escrivão da feira de Capuame. Como exemplo, segue uma referência: APEB. Maço 201-14. Correspondência recebida pelo governo. Senado da Camara da Bahia (1783-1799), 14 de março de 1792.

59. AMS. Atas da Câmara (1649-1659), vol. 3. "Termo que se fez sobre se abrir o caminho da Mata de São João" 24 de abril de 1652. p. 201.

60. O historiador Angelo Emílio Pessoa notou de modo perspicaz que o termo de resolução sobre a abertura do caminho da Mata de São João contou com o apoio e assinatura de vários fazendeiros importantes, exceto Dias D'Ávila. Dificilmente o membro da Casa da Torre não seria consultado para um assunto de seu interesse direto. Além de grande pecuarista, possuía currais na região vizinha à Capuame e auxiliou prontamente o abastecimento das tropas durante os conflitos contra os holandeses, recebendo mais mercês pelos serviços prestados na ocasião. Angelo Emílio Pessoa. As ruinas da tradição - familia e propriedade no nordeste, USP, São Paulo, 2003, p. 119. Para alimentar ainda mais a hipótese, vale notar inclusive que entre os fazendeiros consultados estava Antonio Guedes de Brito, conhecido desafeto do coronel Dias D'Ávila.

61. AMS. Cartas Do Senado (1673-1684), vol. 2. 15 de julho de 1679, p. 62. 
despender de 30 mil réis por ano só para custear o transporte de seus negros e de dois cavalos toda vez que precisava buscar mantimentos ou "acudir os sacramentos e obrigações de seu cargo." 62

Capuame ficava na antiga freguesia suburbana de Santo Amaro de Ipitanga, ${ }^{63}$ termo de Salvador, próximo ao aldeamento jesuítico de Espírito Santo (distante seis léguas da Costa de Itapuã, composta por índios tapajaras e tupis), ${ }^{64}$ transformada em 1758 em Vila de Abrantes como exemplo da política pombalina de secularização destes espaços depois que a Companhia de Jesus foi expulsa das possessões portuguesas. ${ }^{65} \mathrm{Em} 28$ de dezembro de 1759, Antonio Ferreira arrematou duas léguas de terras localizadas na Feira de Capuame. Eram foreiras por enfiteuse ao marques de Louriçal, mas foram sequestradas como sendo um dos bens pertencentes aos jesuítas. ${ }^{66}$ Nos arredores da feira havia também a aldeia dos Manguinhos, parte integrante do termo da vila de Água Fria ${ }^{67}$, composta por índios de nação Caramurú, formada em 1759 ( segundo relato de José Antonio Caldas) por oitenta almas sem nenhum missionário, "arriba da feira da Capuame um dia de viagem". ${ }^{68}$

$\mathrm{Na}$ mesma freguesia de Santo Amaro de Ipitanga ficava Mata de São João, “[...] com povoação de engenho - capella e vários moradores para dentro da terra e a Capella de Santo Antonio da Capuame". ${ }^{69}$ Vale lembrar que Mata de São João foi um dos lugares apontados por Luiz Mott como espaço em que se estabeleceu uma outra feira de gado. ${ }^{70}$ Devido à proximidade em relação ao sítio de Capuame, à proibição de venda de reses em outros locais (que não aquele estipulado pela municipalidade) e fatores vinculados a possível dimensão espacial da feira de Capuame, permanece como hipótese não se tratar necessariamente de uma outra feira de gado e sim do mesmo espaço. O documento utilizado por Luiz Mott para pensar na existência de uma outra feira de gado em Mata de São João data de 1785. Possivelmente naquele ano a freguesia de Mata de São João já tivesse sido desmembrada de Santo Amaro do Ipitanga, ficando a feira de Capuame vinculada a partir de então a primeira freguesia supracitada. $\mathrm{O}$ documento utilizado pelo pesquisador não informa o nome da feira, mencionando somente:

62. AHU. c. 19 doc. 1683. "Consulta do Conselho Ultramarino sobre a petição feita pelo vigário da igreja matriz de Santo Amaro do Ipitanga" 2 de maio de 1724. Bahia . Avulsos.

63. Luiz Mott. "Subsídios à história do pequeno comércio no Brasil". Revista de História, vol. 53, n. 105 (1976).

64. José Antonio Caldas. Notícia geral de toda esta capitania da Babia desde o seu descobrimento até o presente ano de 1759. Salvador, 1951. p. 51

65. Fabrício Lyrio Santos. Da catequese à civilização: colonização e povos indígenas na Bahia (1750-1800), UFBA, Salvador, 2012.

66. "Enumeração dos documentos existentes no Archivo do Instituto Geográfico e Histórico da Bahia". RIGHBa, 1929, vol. 55, p. 605.

${ }^{67}$. José Antonio Caldas, op. cit, p. 300.

68. Idem, p. 51

69. $A A P B$. Manoel de Oliveira Mendes. "Livro de cartas do Senado para Sua Magestade, 1746-1822 Relação topographica da Cidade do Salvador da Bahia de Todos os Santos e seu termo que fez o medidor das Obras da Cidade Manoel Mendes", vol.1, p. 12 e segs.

70. Luiz Mott. "Subsídios à história do pequeno comércio no Brasil”. Revista de História, vol. 53, n. 105 (1976), p. 86. 
“A freguesia da Mata de São João contem em si mais de 300 fogos unidos e no seu terreno se faz a grande feira dos gados, que entram semariamente [sic] para a sustentação de toda esta cidade e seu recôncavo, e deste importantíssimo ramo de negócio procede o serem inumeráveis as pessoas que concorrem a ela e habitam na sua vizinhança." 71

Esta feira sem dúvida alguma era Capuame. Esta hipótese é reforçada mediante as informações localizadas em alguns documentos coevos que evidenciam o fato de Capuame ser primeiramente vinculada à freguesia de Santo Amaro do Ipitanga e posteriormente estar no terreno pertencente à Mata de São João. Devido a sistemática proibição de venda de gado vaccum em outra localidade, certamente a feira retratada era Capuame.

Em 1723, foi expedida uma ordem para que todo o gado localizado no distrito de Água Fria fosse encaminhado ao capitão Antonio Alvares Matos estacionado nos arredores de Capuame, próximo a Fazenda Grande da Mata de São João, para assim conduzir as boiadas até Salvador. Na mesma ocasião, cabia ao Coronel Antonio Homem de Afonseca enviar ao governador uma relação com todas as boiadas e número de cabeças que fossem localizadas naquelas paragens. ${ }^{72} \mathrm{~A}$ Fazenda da Mata aparece novamente nos "Livros de Registros de Entrada de Gado" da feira de Capuame como um dentre os muitos espaços nos quais as boiadas vindas dos sertões permaneciam "empastouradas" até o momento de serem conduzidas à capital, ${ }^{73}$ mostrando assim a proximidade de Mata de São João com a Feira de Capuame. Na região também estava localizado o famoso Engenho da Mata, propriedade dos herdeiros do grande sesmeiro Guedes de Brito, formadores da Casa da Ponte. ${ }^{74}$ Ainda não sabemos se há alguma similaridade entre o engenho e a fazenda da Mata ou se pertenciam à mesma família.

Em fins do século XVIII, Capuame constava como se fizesse parte da freguesia da Mata de São João, possivelmente já desmembrada da primitiva Santo Amaro do Ipitanga. O "Guia de caminhantes", coleção de mapas de 1801, mostra cartograficamente a proximidade da feira com a Fazenda da Mata, ressaltando novamente tratar-se de locais próximos. E por último: somente uma referência à feira da Mata de São João foi localizada nos documentos compulsados durante a pesquisa. ${ }^{75}$ Pode ser (e é muito provável) que lá existisse de fato alguma espécie de feira rural de produtos variados, mas

\footnotetext{
71. AHU. Bahia, 4/9/1785. Apud. Luiz Mott, op. cit. p. 89.

72. APEB. Secção Colonial. "Portarias (1722-1724)" n. 461, fl. 153.

73. Registro referente a trinta e três reses deixadas empastouradas por Capitão Manoel dos Santos na feira de 25 de abril de 1787. AMS. "Livro de Registro de entrada de Gado" (1784-1789) fl. 137.

74. No livro de José Antonio Caldas, Manoel Saldanha aparece como possuidor de uma alambique no Engenho da Mata. José Antonio Caldas. Notícia geral de toda esta capitania da Babia desde o seu descobrimento até o presente ano de 1759. Salvador, 1951, p. 447. No inventário de João de Saldanha da Gama Mello Torres Guedes de Brito, o conde da Ponte, o engenho da Mata de São João aparece como um dos bens arrolados. "Cópia do inventário do Conde da Ponte, João de Saldanha da Gama Mello Torres Guedes de Brito, falecido em 24 de maio de 1809 com testamento.” AAPB. Bahia (28): p. 42-75, 1945. p. 46.

75. APEB. Correspondência recebida pelo governo. Senado da Câmara da Bahia (1783-1799). 3 de abril de 1798 .
} 
não uma feira de gado concorrente à Capuame, na medida em que a fonte localizada denuncia a venda irregular de bois sertanejos na feira da Mata.

A circunscrição da área onde possivelmente estava localizada a feira de Capuame é relativamente extensa. Condiz com as informações e relatos sobre a existência de uma quantidade significativa de pousos, pastos e até mesmo fazendas e sítios no final do século XVIII. ${ }^{76}$ Entre os atuais municípios de Camaçari e Dias D'Ávila, a região era formada por uma paisagem sempre muito homogênea, ${ }^{77}$ descartando evidentemente as partes mais escarpadas e de vegetação mais densa como o local atualmente considerado a Área de Preservação Ambiental denominada Ipitanga. Aqui mais uma referência ao antigo nome da freguesia, Santo Amaro do Ipitanga, que segundo a descrição de 1757 “occupa de Norte a Sul 21 légoas [e] compreende o Rio Joannes”.

Capuame ficava na região que se encontrava sob poder e influência do regimento comandado pelo Coronel Dias D'Avila. Segundo o testamento de 1609, as terras da região do Rio Jacuípe até o vale do São Francisco pertenciam à família do grande sesmeiro. ${ }^{78}$ A partir de 1613 , com a nomeação de Dias D'Ávila para o cargo de capitão do novo regimento que possuía como circunscrição coincidente as terras de suas sesmarias, a Casa da Torre passou a ter o controle militar da região por gerações seguidas de homens ostentando as patentes de mestre-de-campo e coronel. ${ }^{79}$ Não é a toa que boa parte da historiografia credita aos membros da Casa da Torre a criação da feira de Capuame. Entretanto, havia um conflito por terras na região, visto a sesmaria entregue ao conde de Castanheda nunca ter sido efetivamente ocupada pelos "agraciados" com a mercê, passando o domínio da área para o Conselho Municipal, por mais que os Dias D'Ávila tentassem a todo custo promover o aumento dos limites de suas sesmarias. ${ }^{80}$

Por mais de um século os membros da Casa da Torre - enquanto funcionários régios e militares - estiveram diretamente envolvidos com o arrebanhamento do gado vindo inclusive de suas várias fazendas espalhadas

\footnotetext{
76. No inicio da década de 1730 a Feira de Capuame tinha "conveniência de pastos e duas casas como moradores e ranxos [sic] para passageiros." Joaquim Quaresma Delgado. "Derrota da Cidade da Bahia para as Minas da Jacobina." Erivaldo Fagundes Neves e Antonieta Miguel (org.) . Caminhos do sertão: ocupaçã territorial, sistema viário e intercâmbios coloniais dos sertões da Babia, 2007, p. 68.

77. O cálculo aproximado foi feito de modo absurdamente amador com o auxílio do site de Georreferenciamento Daft

Logic < http:/ / daftlogic.com>

78. Pedro Calmon. História da Casa da Torre: uma dinastia de pioneiros. Rio de Janeiro, 1939.

79. Segundo o testamento de 1609 parte das terras da região da Torre de Tatuapara até o São Francisco, seguindo para o interior, pertenciam a família de Dias D'Avila. Faziam fronteira com as terras do conde de Castanheda que nunca chegaram a ser confirmadas, passando então para o domínio da Câmara Municipal de Salvador, compreendendo aldeamentos, além de abrigar uma quantidade significativa de posseiros. A partir de 1613, com a nomeação de dias D'Ávila para o cargo de capitão do regimento que ia do Rio Jacuípe até o Rio São Francisco, todos os seus descendentes passaram a ter controle militar sobre a região, possuindo subsequentemente patentes de mestres-decampo, coronéis. Ver: Pedro Calmon, História da Casa da Torre, Rio de Janeiro, 1939, p. 38; José Antonio Caldas. Notícia geral de toda esta capitania da Babia desde o seu descobrimento até o presente ano de 1759. Salvador, 1951. p. 274. Para uma visão crítica sobre a Casa da Torre, ver: Angelo Emílio Pessoa. op. cit. 80. Sobre os embates em relação às terras que estava estabelecida a Feira de Capuame, ver: RIHGB, 1930, vol. 56, p. 531-532.
} 
pelos sertões adentro, chegando até o sul do Piauí. ${ }^{81}$ No sentido de controlar a quantidade de gado com que os administradores de Salvador podiam contar para abastecer a cidade, era necessário que o sargento-mor do regimento de Dias D'Ávila fizesse sempre que solicitado uma lista contendo obrigatoriamente o levantamento do número de reses disponíveis no lugar chamado Capuame. ${ }^{82}$

Este controle estava intimamente relacionado aos problemas que a falta de gêneros tais como a carne verde poderia acarretar à vida dos habitantes da cidade de Salvador cada vez mais dependentes das mercadorias produzidas em outras regiões. Motivo de revoltas e motins, depois que boa parte da população já não produzia mais para si, o abastecimento sempre foi visto como uma preocupação de maior grandeza pelas autoridades de Antigo Regime, não só em Salvador ${ }^{83}$, mas também nas Minas Gerais ${ }^{84}$, Rio de Janeiro, ${ }^{85}$ no Reino de Portugal, bem como no restante da Europa ${ }^{86}$. Todo o comércio de carne verde ou fresca, assim como os demais alimentos considerados de "primeira necessidade", eram regulados pela Câmara Municipal. ${ }^{87}$ Esta era uma diretriz vinda da metrópole e servia para todos os domínios e colônias do Império. 88 Trataremos deste assunto no terceiro capítulo.

Na segunda metade do século XVII os esforços de abastecimento eram mais vinculados à necessidade de alimentar os membros dos destacamentos militares, funcionários régios, burocratas e moradores abastados da cidade de Salvador, além de contribuir para a arrecadação das fintas Reais, garantindo a recuperação das finanças da colônia após o término da guerra contra os holandeses e o pagamento de acordos de paz e dotes corriqueiramente enviados para a metrópole

Contando com a conversão dos sesmeiros e "práticos dos sertões" em colaboradores diretos para a produção das condições básicas de reprodução interna à colônia, as fazendas sertanejas dedicadas à pecuária tornaram-se não só unidades esparsas de efetivação do domínio lusitano na hinterlândia, como

\footnotetext{
81. Angelo Emilio Pessoa, op. cit.

82. DH. "Ordem para o Sargento-maior Balthazar dos Reis Barrenho ir listas todos os gados que há do distrito da Vigia até a Torre". 16 de novembro de 1654. vol. 4, p.177.

83. Avanete Pereira Sousa. Poder local, cidade e atividades econômicas (Babia, século XVIII). USP, São Paulo, 2003.

84. Flávio Marcus da Silva. Subsistência e poder. A política de abastecimento alimentar nas Minas setecentistas. UFMG, Belo Horizonte, 2002.

85. Alcir Lenharo. As tropas de moderação. (O abastecimento da Corte na formação política do Brasil - 1808 1842). Simbolo, São Paulo, 1979; Paulo Henrique Pedreira Campos. Nos caminhos da acumulação: negócios e poder no abastecimento de carnes verdes para a cidade do Rio de Janeiro, 1808-1835. UFF, Niterói, 2007.

86. Edward Palmer Thompson. Costumes em comum. Estudos sobre a cultura popular tradicional. São Paulo, 1998; Karl Polanyi. A Grande Transformação: as origens da nossa época. Rio de Janeiro, 2000; Fernand Braudel. Civilização material, economia e capitalismo, séculos XV-XVIII. São Paulo, 2009, vol. 2 Os jogos das trocas.

87. Avanete Pereira Sousa, op. cit.

88. Rui Santos. "Mercados, poder e preços: a marchantaria em Évora (séculos XVII a XIX)". Penélope, vol. 21, 1999, p. 63-93.
} 
também pontos de apoio para a ampliação do poderio metropolitano pelos sertões através do auxílio dado aos grupos itinerantes e expedições sertanistas. Permitiam simultaneamente o crescimento de especialização da grande lavoura, criando uma economia de retaguarda diretamente vinculada às necessidades e interesses da colônia como um todo. Nesse sentido, Capuame aparece como o local para onde convergia todo o gado confiscado dos súditos reais que tinham por obrigação colaborar com a manutenção das tropas, direcionando também parte da produção separada para socorrer os burocratas e demais trabalhadores da cidade de Salvador. ${ }^{89}$

Com o início da colonização das Minas Gerais, a imigração crescente e o surgimento de um novo mercado que precisava ser abastecido, não só aumentou o trânsito de pessoas e mercadorias pelos sertões baianos e consolidou as fazendas de gado vaccum espalhadas pelo interior, como também deu impulso a uma outra lógica de produção e circulação da mercadoria gado. Já não importava mais única e exclusivamente o gado enquanto forma de pagamento ou alimentação direta da máquina de guerra e da estrutura burocrática. Fazia-se necessário a partir do século XVIII alimentar a população que já não dava mais conta de criar as suas próprias condições de reprodução dos meios de vida dentro de um espaço cindido e cada vez mais pautado pela divisão social do trabalho. Os centros mineradores, os espaços de florescimento urbano $\mathrm{e}$ as grandes fazendas monocultoras não foram evidentemente a regra da ocupação colonial, mas sem dúvida alguma deram o tom da dinâmica interna e externa à América Portuguesa, além de concentrarem juntas a maior parte da população e cabedal. $O$ sentido profundo da exploração especializada, ou seja, a acumulação primitiva de capital, requeria o crescimento necessário de setores que produzissem aquilo que os trabalhadores dos setores exportadores não podiam mais garantir para si: os meios de vida necessários para sua reprodução diária. ${ }^{90}$

Empurradas sempre que possível para o interior, as relações de produção impostas pela criação de gado traçavam junto com o palmilhar das boiadas uma nova tessitura social, não totalmente alheia ao restante da colônia - como

89. DH.“Assento que se faz de como Agostinha de Medeiros há de cobrar cada anno pela folha do assentamento desta Capitania cem mil réis por conta de quatrocentos quatorze mil quatrocentos e dous réis que monta um mandado do Conde General Antonio Telle de dezessete de setembro de seiscentos quarente e nove no qual vão incluidos outros que fazem a dita quantia que são de gado." 12 de dezembro de 1659. vol. 20, p. 135-136; AHU. AHU_CU_003, Cx. 2, D. 144. Requerimento de Baltazar Gomes dos Reis natural de Barcelos e morador na cidade da Bahia, ao rei [D. Pedro II], solicitando o hábito de Cristo com tença efetiva para seu neto Antônio de Oliveira Guedes e, para si, a propriedade de um dos ofícios de escrivão do Público, Judicial e Notas na vila da Cachoeira ou na de Sergipe do Conde, ou do ofício de escrivão dos Feitos da Fazenda vago por falecimento de Antônio Teles, em satisfação dos seus serviços e dos seu sogro Simão de Oliveira Serpa, natural de Tarouca, prestados na Bahia. Obs.: m. est.; Em anexo fé de ofícios, certidões, carta patente, sentença de justificação, folha corrida, mandado, atestados, instrumento em pública forma. [ant. 1700, Fevereiro, 15, Bahia] cx. 3, doc. 84; DH. "Portaria que levou o capitão-mor Brás Roiz de Arzão" 9 de maio de 1673; DH. "Portaria que se passou ao Sargento Pedro Gomes para tomar o gado necessário para o sustento da gente do sertão. "16 de Outubro de 1657. p. 56.

${ }^{90}$. Segundo Barickman, fazia-se necessário para a expansão da economia de exportação o desenvolvimento do mercado interno e a consolidação de regiões que produzissem os alimentos necessários para manter os trabalhadores livres e escravos das fazendas monocultoras. J. B. Barickman. Um contraponto baiano. Rio de Janeiro, 2007, p. 30. 
querem aqueles que frisam a caráter excepcional e desarticulado da atividade criatória em relação à grande plantação. Evidente que o crescimento da exploração/especialização requeriam uma diferenciação das regiões, uma nãosimultaneidade, ou se preferirem "uma forma particular que a acumulação primitiva assume" 91 . As características impostas à exploração da pecuária nos sertões baianos tinham em vista a sua relação íntima como a grande lavoura e posteriormente com os centros de mineração. $O$ gado que enfrentava as enormes distâncias guiado por condutores escravos e livres em direção aos mercados consumidores e pontos fixos de comércio tais como a feira de Capuame transformava-se cada vez mais em mercadoria, ${ }^{92}$ modificando inclusive o papel social daqueles envolvidos com o seu encaminhamento e posterior comércio generalizado. $\mathrm{O}$ alimento precisava ser produzido com custo sempre o mais reduzido possível para possibilitar uma maior concentração das taxas de ganância nos setores que empregam mais trabalho compulsório e despendem maior cabedal. Pensando em um processo global de produção, de fato a pecuária precisava ter baixos custos para garantir o baixo preço de uma mercadoria essencial para a reprodução diária da força de trabalho da maior parte dos homens coloniais. Vale notar na maior parte dos relatos que a ração básica em muitas situações era composta por carne e farinha. ${ }^{93}$

\section{$* *$}

Em carta de primeiro de julho de 1686, o governador-geral alertou os vereadores da Câmara Municipal de Salvador sobre os problemas e as implicações político-econômicas vinculadas à falta de carne verde para abastecer a cidade, chegando ao ponto de atrapalhar os negócios anuais da Frota (Naus das Índias) na medida em que os marchantes (comerciantes de gado), sabendo da alta precisão que a tripulação das embarcações tinham da carne para seguir viagem, acabavam por cobrar irregularmente um preço exorbitante pelo produto, muito mais elevado do que o valor estipulado pela municipalidade. ${ }^{94}$

A mesma correspondência falava sobre o costume dos homens que trabalhavam na marchantaria de deixarem gado "empastourado" para além do Rio Joanes, ou seja, no sítio da Capuame, onde conseguiam regular o oferta do gênero deixando-o parado ou encaminhando para o açougue público de Salvador conforme sua vontade e cobiça. Constava que havia ao menos uma

91. Carlos Almeida Toledo. A região das Lavras Baianas. USP, São Paulo, 2008, p. 11.

92. Importante lembrar que as coisas não têm naturalmente a característica de se transformarem em mercadoria.

93. Pe. Martinho de Nantes. Relação de uma missão no Rio São Francisco. São Paulo, 1979, p. 35; Laura de Mello e Souza. "Formas provisórias de existência: a vida cotidiana nos caminhos, nas fronteiras e nas fortificações." Fernando Antonio Novais (org.) História da vida privada no Brasil. Vol. 1: Cotidiano e vida privada na América Portuguesa. São Paulo, 1997. p. 41- 81; Antonio Gomes Ferrão Castelo Branco. Borrador em que lanço todas as cartas que escrevo, principiado em agosto de 1742, estando na Babia. São Paulo, Coleção Mindlin. Transcrito por Rosana Gonçalves sob orientação da Profa Dra Mary Del Priore e gentilmente cedido pelo Prof. Dr. Istvan Jancsó.

94. AAPB. "Portaria para os oficiais da Câmara desta Cidade sobre os marchantes não venderem a carne por mais de seis réis a libra.” Bahia, 1 de julho de 1686. vol. 8, p.10. 
quantia de mil reses (cabeças de gado) por aquelas paragens, sob responsabilidade dos mesmos marchantes que deveriam conduzir as boiadas ao matadouro e açougue público de Salvador mas preferiam esperar e forçar uma elevação no preço do bovino. ${ }^{95}$

No termo de vereação de 22 de setembro de 1696, os funcionários da Câmara discutiram sobre a necessidade de estipular o preço da carne cortada nos açougues pelo valor de doze vinténs a arroba, visto ficarem sabendo que "os compradores de gado que são os marchantes" faziam conluios para forçar o aumento do preço da carne, demorando para encaminhar gado à cidade mesmo havendo fartura de reses estacionadas em Capuame. ${ }^{96}$

Cabia aos militares, em geral o capitão do regimento da Torre dos Dias D'Avila, cuidar para que as boiadas sertanejas levadas até os pastos e invernadas do distrito de Capuame fossem devidamente encaminhadas até os currais e matadouro público de Salvador pelos marchantes. Lá somente os licenciados poderiam comprar a carne, precavendo-se para que não agissem na localidade os atravessadores ${ }^{97}$, desviadores de gado acostumados a matar as reses em lugares clandestinos e vender os talhos (pedaços de carne) na praia por um preço mais alto daquele de costume quando não havia oferta suficiente do produto. Tudo isso para garantir que não houvesse falta de carne para o abastecimento da tripulação das Naus de Sua Majestade como na semana do dia 23 de abril de 1712.98 A mesma informação sobre os desvios do gado arrebanhado em Capuame aparece na correspondência emitida pelo governador general ao ajudante Francisco Luiz em 8 de outubro de $1718 .{ }^{99}$

Sendo assim, é possível perceber que as primeiras referências documentais feitas sobre a existência do sítio de Capuame (enquanto ponto oficial do arrebanhamento das reses sertanejas) estavam vinculadas às inúmeras reclamações sobre as irregularidades do fornecimento realizado pelos marchantes que controlavam a oferta do alimento e as denúncias de contrabando e venda clandestina em locais não-oficiais, restando poucas informações sobre a sua dinâmica de funcionamento e a configuração do espaço de comércio na virada do século XVII para o XVIII.

Interessante notar que o período testemunhou uma mudança de caráter e de razão de ser do próprio sítio de Capuame. Se em um primeiro momento era visto como um ponto de arrebanhamento capaz de concentrar os rebanhos sertanejos, conforme se aproximava o final do século XVII, foi possível notar a ocorrência de informações sobre a comercialização crescente do gênero, transformando o espaço em ponto de venda do gado em pé. Se antes a

\footnotetext{
95. Idem.

96. AMS. "Termo de vereação e resolução que tomaram os oficiais da Camara sobre se dar carne ao povo esta semana” 22 de setembro de 1696. Atas da Camara (1684-1700) vol. 6, p. 324.

97. O termo atravessador aparece sempre na documentação como sinônimo de contrabandista. Isto foi verificado também por Fernand Braudel. op. cit. e E.P. Thompson. op. cit. p. 156.

98. DH. "Portaria para o Capitão-mor Domingos Alves fazer vir para esta cidade todo o gado que chegar ao distrito Capoame" 23 de abril de 1712. vol. 53, p. 160.

99. DH. "Portaria que levou o ajudante Francisco Luiz para a diligência a que foi da prisão dos marchantes e condução dos gados." 8 de outubro de 1718. vol. 55, p. 114.
} 
condução das boiadas era feita de forma praticamente compulsória, contando com o confisco e tomada de reses por militares pertencentes a determinados regimentos, na virada do século é possível perceber uma consolidação da comercialização de gado, envolvendo grandes fazendeiros e negociantes. Trataremos deste último aspecto no segundo capítulo.

Certamente o abastecimento de carne verde e gado em pé à cidade de Salvador aparece como um problema constante a ser debatido e solucionado do modo mais rápido possível pelos funcionários municipais principalmente a partir da virada para o século XVIII ${ }^{100}$, quando do aumento populacional da colônia devido especialmente ao movimento migratório de europeus atraídos pela descoberta do ouro nas Minas Gerais e o consequente aumento do tráfico negreiro. O comércio e a oferta de gêneros de primeira necessidade tornou-se nas primeiras décadas do século XVIII um problema corriqueiro para as autoridades municipais responsáveis por regular o fornecimento de alimentos à população no momento em que os movimentos migratórios (compulsórios ou não) começaram a pressionar os setores produtivos da colônia. ${ }^{101}$

Com a obrigatoriedade dos marchantes encaminharem diretamente para o matadouro público todas as reses que trouxessem de Capuame, mediante o pagamento de crescentes impostos, os contrabandistas e atravessadores, por sua vez, não perderam a oportunidade de auferir lucros astronômicos com o crescimento da demanda.

É notório entre os documentos restantes do Tribunal da Relação da Bahia os casos em que atravessadores e até mesmo marchantes foram condenados por contrabandearem carne. As multas e a quantidade de dias que eram mantidos em cárcere não pareciam ser suficientes para diminuir os delitos e muito menos as reincidências. ${ }^{102}$ Para o caso específico do abastecimento de carne verde, várias foram as iniciativas dos governantes no sentido de resolver os problemas da condução das boiadas vindas dos sertões baianos. A mais citada e debatida foi a necessidade de fiscalização constante no distrito de Capuame, local em que os agentes envolvidos com o comércio dos bovinos - os marchantes - costumavam atuar, controlando o transporte das boiadas conforme os seus interesses.

100. É curioso perceber o aumento significativo de termos de vereações constantes nas Atas da Camara Municipal de Salvador referente aos problemas de abastecimento e sobretudo a carestia e os constantes desvios e contrabando. Esse assunto será tratado com maiores detalhes no terceiro capítulo. AMS. "Termo de vereação e resolução que se tomou sobre uma carta que escreveu o senhor governador Dom Rodrigo da Costa sobre se aplicar todo o cuidado para que não haja falta de gado para os açougues." 27 de setembro de 1702, p. 119, vol. 7

101. Os debates sobre o abastecimento e o suprimento de carne verde a cidade de Salvador aparecem com maior frequência nos documentos compulsados a partir da virada do século XVIII. Ver: AMS. Atas da Câmara Municipal de Salvador; $A P E B$. Cartas expedidas do governador à várias autoridades; APEB. Tribunal da Relação.

102. Para alguns exemplos do início do século XVIII, ver: APEB. Tribunal da Relação. Alvarás e provisões. Maço 502 (1712-1715), fl. 12,13, 20, 66, 70, 103, 104, 114, 115, 117, 169, 203; Maço 503 (1715-1718), fl. 109, 237; Maço 504 (1718-1720), fl. 33, 48, 126, 134, 141, 182, 225; Maço 505 (17201722), fl. 3, 77, 83, 129,130, 177, entre outros. 
Data deste período o crescente incentivo das autoridades régias àqueles interessados em atuar como fornecedores diretos do gado vaccum produzido. $\mathrm{O}$ estabelecimento de fazendas pecuaristas nos sertões baianos era a grande justificativa para o pedido de terras em forma de sesmarias. ${ }^{103}$ Para fomentar a produção e beneficiar os pecuaristas, foi decretado o apoio incondicional aos criadores de gado que se deslocassem de suas unidades produtivas para encaminhar as boiadas até o litoral, além da decisão terminante de proibição da venda de reses fora do sítio de Capuame em $1726 .{ }^{104} \mathrm{O}$ incentivo aos criadores de gado veio por parte do governador general que resolveu dar despacho a todos os produtores e pecuaristas que trouxessem escravos à cidade para $\mathrm{O}$ trabalho de condução dos rebanhos ou os levassem para os sertões para o benefício das suas fazendas, autorizando o livre trânsito dos cativos sem o pagamento de qualquer imposto ou direito de entrada pelos locais em que passassem. ${ }^{105}$

A partir de 1727, Capuame deixou de ser tratada como um mero ponto de arrebanhamento e ajuntamento do gado sertanejo, destinado ao abastecimento da cidade de Salvador, para ganhar o status de feira institucionalizada, possuidora de um registro de entrada de gado e todo um aparato burocrático mantido e assegurado com o auxílio de funcionários nomeados pela Câmara Municipal e com cargos confirmados pelo governador general. ${ }^{106}$

Devido ao duplo casamento dos príncipes Dom José de Portugal com Dona Mariana Victoria de Bourbon e Dom Fernando (príncipe de Astúrias e futuro rei da Espanha) com Dona Maria Bárbara de Portugal107, coube à América Portuguesa arcar com uma parte dos gastos que o dote e as diversas cerimônias e festejos para selar o arranjo diplomático requeriam. A contribuição da colônia seria feita com uma quantia determinada em dinheiro a ser enviada anualmente para a metrópole. Para cumprir com a parte que cabia à capitania da Bahia e à Camara Municipal de Salvador, foi decidido pela criação de um novo tributo que recairia sobre os súditos da colônia americana daquela localidade. O produto escolhido para ser tributado foi o gado em pé. O modo de cobrança estabelecido foi a implementação de um registro de

103. Tatiana da Cunha Peixoto. Os mandarins do sertão: os criadores de gado do São Francisco (1650-1750). Belo Horizonte, UFMG, 2006.

104. DH. "Carta para o Coronel Domingos Borges de Barros" 11 de maio de 1726 . vol. 72 . p. 324.

105. Idem.

106. BN. Catálogo 68. 130A: Registro das cartas que expediram para a Cidade, vilas, capitanias e sertão (1726-1728). "Instrução que há de observar o capitão Luiz Pereira de Almeida a quem tenho encarregado a remessa do gado da feira da Capuame para esta cidade." 7 de julho de 1727; DH. "Provisão da serventia do ofício da Superintendência do Registo do Gado da Capuame provido na pessoa do Capitão Luiz Pereira de Almeida ." 15 de março de 1728. Vol. 48, p. 208 . DH "Provisões do dia 15 de março de 1728". Documentos Históricos da Biblioteca Nacional, volume 48, 1940, p. 208- 213.

107. Os festejos e destintos acordos diplomáticos ocorreram entre os anos de 1727 e 1729 em vários locais distintos da Península Ibérica. O episódio ficou conhecido como a troca das princesas. José Manuel Tedim. "O triunfo da festa barroca a troca das princesas". Arte efémera em Portugal. Lisboa, 2000 . 
entrada de gado no ponto de convergência das boiadas vindas dos sertões em direção à capital da colônia: Capuame. ${ }^{108}$

Era comum que casamentos, acordos de paz ${ }^{109}$ e inclusive reconstruções após acidentes naturais, tais como o terremoto que destruiu a cidade de Lisboa em $1755^{110}$ fossem pagos com dinheiro arrecadado graças à tributação imposta às colônias dos reinos europeus: os "donativos".111 Esse foi o caso da imposição que originou a necessidade de criar todo um mecanismo de cobrança de direitos sobre o comércio e a passagem das boiadas pelo sítio de Capuame.

A institucionalização de Capuame em forma de feira ocorreu como uma espécie de formalização de um comércio que já acontecia. Através do relato do padre jesuíta Antonil, sabe-se que em 1711 já era notório a compra de gado pelos marchantes naquela região. Interessante notar que em nenhum momento o jesuíta mencionou o funcionamento de uma feira em Capuame; somente a existência de pastos nos quais as trocas comerciais eram realizadas. ${ }^{112}$ Com o estabelecimento do registro de entrada de gado, a municipalidade passou a ter um maior controle sobre todas as boiadas que passavam por Capuame em direção aos currais e açougues públicos espalhados pela cidade de Salvador. Para garantir uma cobrança mais efetiva do imposto, foi necessário a implementação de todo um esquema para registrar o gado que ali entrasse, contando com o trabalho de funcionários nomeados pela Câmara Municipal. Impedir (ou ao menos coibir/proibir) qualquer tipo de desvio do gado encaminhado à capital da colônia seria o grande desafio das autoridades régias que atuavam na localidade. ${ }^{113}$

Portanto, foi depois do decreto do Rei sobre a necessidade de auxílio da América Portuguesa para o pagamento dos dotes e custos dos casamentos do príncipes de Portugal que surgiu a necessidade da criação de todo um aparato que dinamizasse e institucionalizasse de algum modo a estrutura de comércio e arrebanhamento já existente em Capuame. Fazia-se urgente também, na perspectiva do poder colonial, garantir que o gado destinado ao

108. DH. "Provisão da serventia do ofício da Superintendência do Registo do Gado da Capuame provido na pessoa do Capitão Luiz Pereira de Almeida ." 15 de março de 1728.

109. Evaldo Cabral de Mello. O Negócio do Brasil. Portugal, os Países Baixos e o Nordeste, 1641-1669, Rio de Janeiro, 1998, p. 227 e segs

110. Na ocasião do Terremoto de Lisboa e a imposição do donativo, houve um abaixo assinado de moradores da cidade da Bahia posicionando-se contra a cobrança. Carolina Chaves Ferro. Terremoto em Lisboa, tremor na Babia. Um protesto contra o donativo para a reconstrução de Lisboa. Niterói, UFF, 2009.

111. A paz de Holanda e o dote da "Senhora Rainha da Grã-Bretanha" cobrados na década de 1670 também foram tarifados a partir da produção de gado da capitania da Bahia e Sergipe Del Rey. AMS. Atas da Câmara (1669-1684), vol. 5, 19 de setembro de 1671, p. 49 ; "Termo de resolução que tomarão os oficiais da Câmara sobre se fazer lançamento nas fazendas de gado do sertão que há muitos anos se não fez para o donativo da paz de Holanda e dote da senhora Rainha da GrãBretanha." 10 de novembro de 1674.p. 150; "Resolução que se tomou sobre assento do gado para o dote da sereníssima Rainha da Grã-Bretanha e paz da Holanda.” 30 de maio de 1676, p. 185.

112. André João Antonil. Cultura e Opulência do Brasil por suas drogas e minas . [1711] São Paulo, 2007.

113. BN. Catálogo 68. 130A: Registro das cartas que expediram para a Cidade, vilas, capitanias e sertão (1726-1728). "Instrução que há de observar o capitão Luiz Pereira de Almeida a quem tenho encarregado a remessa do gado da feira da Capuame para esta cidade." 7 de julho de 1727 
litoral passasse obrigatoriamente por lá, tornando proibido todos os outros caminhos e passagens concorrentes que permitissem o desvio das boiadas do seu centro de registro. A nomeação de alguns funcionários de confiança foi um dos primeiros passos para assegurar uma cobrança eficiente do direito de passagem através do registro recém-criado.

\section{Gráfico 1:}

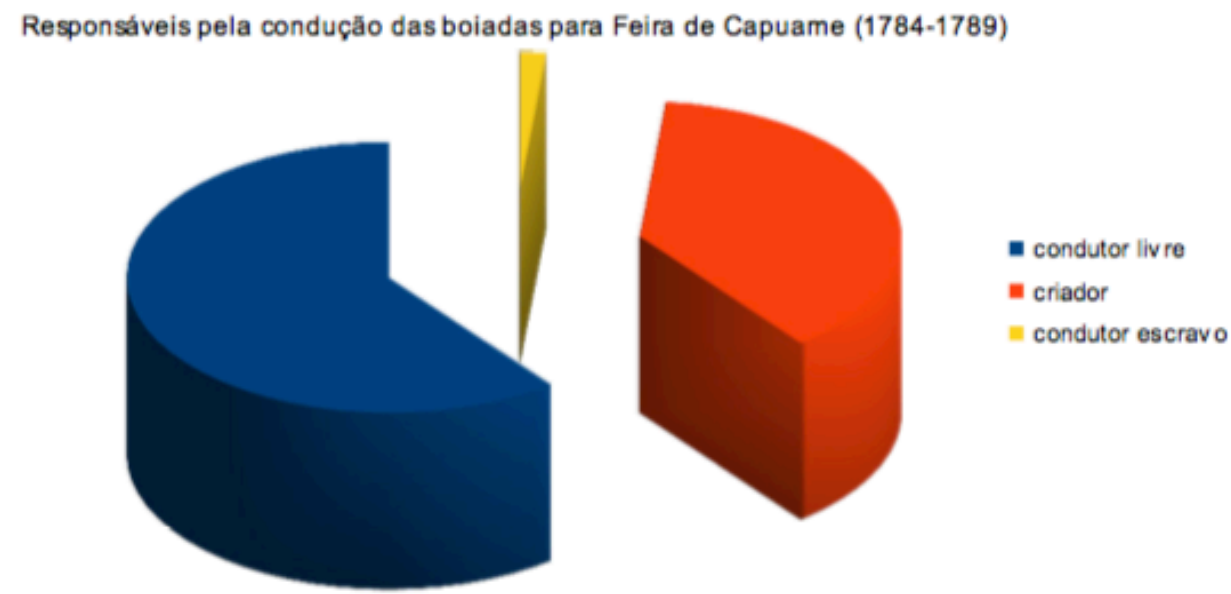

Ref.: $\quad A M S$. "Livro de Registro de Entrada de Gado" da feira de Capuame (1784-1789)

É interessante notar que a nomeação dos funcionários e a normatização das diretrizes para o estabelecimento do registro de entrada de gado e o novo imposto referente à carne que recaía sobre a capitania da Bahia aconteceram em uma época próxima (e possivelmente anterior) à Páscoa. Aqui será somente mencionado - para chamar atenção - um dado corriqueiro na análise sobre as várias etapas da comercialização da carne verde: a Páscoa aparece em vários documentos da época como um momento de fechamento de ciclo. Desta forma, depois do Entrudo (Carnaval), durante os períodos de Quaresma, os contratos de arrematação das rendas de talhos, cálculo da "safra"114 anual e novas diretrizes sobre o comércio de carne eram estabelecidas na colônia. Esse assunto será retomado especialmente no terceiro capítulo.

O primeiro funcionário a receber provimento do governador general (respeitando a escolha confiada aos funcionários da Câmara Municipal de Salvador) foi o ocupante do cargo de superintendente da administração do registro de gado "que se fez na Capuame", "para a melhor arrecadação do tal

114. Mesmo que safra atualmente seja um termo mais familiar quando referente à produção de gêneros agrícolas, na documentação coeva foi essa a palavra usada como referência ao total produzido em um determinado período. APEB. Correspondência recebida pelo governo. Senado da Câmara da Bahia (1783-1799). Maço 201-14. 3 março de 1790, 14 de março de 1792, 27 de fevereiro de 1793, 29 de março de 1794, 17 de fevereiro de 1796, 13 de setembro de 1797. 
imposto". ${ }^{115}$ O nomeado para ocupar o mais alto posto da administração da nova superintendência criada foi o capitão Luiz Pereira de Almeida em 15 de março de 1728. O ordenado estabelecido era a quantia de $300 \$ 000$ (trezentos mil réis) por ano a serem pagos com o valor arrecadado pelo registro de gado. ${ }^{116}$

O segundo funcionário nomeado pela Câmara e com o posto e provisão confirmados pelo governador foi o tesoureiro, Manoel da Costa Leitão, vencendo como ordenado a quantia anual de $24 \$ 000$ (vinte e quatro mil réis). O tesoureiro certamente era o responsável por arrecadar e manter guardado o dinheiro total coletado até o momento de ser transportado em segurança para os cofres públicos da cidade de Salvador. ${ }^{117}$

O último nomeado foi o funcionário responsável pelo cargo de escrivão do registro de entrada de gado da Capuame, Amador de Araújo. Receberia a quantia de $60 \$ 000$ (sessenta mil réis) por ano e possivelmente teria a obrigação de emitir todos os documentos oficiais, assim como registrar em um livro específico todas as informações relevantes para a feira tais como a quantidade de reses (bois) que entravam semanalmente em Capuame e o valor total arrecadado. 118 Interessante observar nos "Livros de Registro de Entrada de Gado" da feira de Capuame restantes a relativa autonomia que os escrivães possuíam na hora de preencher os documentos. Contanto que constasse as informações básicas sobre a quantidade de gado, o local de origem e o nome do criador ou condutor, pouco importava a sistemática e o modo de organização das informações. Daí resulta alguns livros serem mais bem conservados e de mais fácil inteligibilidade do que outros, muitas vezes ilegíveis e de difícil sistematização para o historiador. Para este estudo foi usado somente o "Livro de Registro de Entrada de Gado" referente aos anos de 1784-1789.

Mesmo com as constantes mudanças das regras e diretrizes sobre o comércio e condução do gado, alguns princípios básicos mantiveram-se vigentes por todo o período em que funcionou a feira no sítio de Capuame. Sendo assim, é possível elencar alguns pontos no intuito de traçar um quadro geral sobre os passos do gado desde as fazendas e estradas sertanejas, passando pela feira de Capuame até chegar ao destino final: os açougues públicos da cidade de Salvador nos quais se apinhavam os moradores da grande cidade.

As boiadas vindas de variados pontos dos sertões baianos eram conduzidas por cerca de sete a dez homens possivelmente armados e práticos

\footnotetext{
115. DH, vol. 48, p. 208.

116. Idem.

117. DH. "Provisões do dia 15 de março de 1728". Documentos Históricos da Biblioteca Nacional, volume 48, 1940, p. 208- 213

118. Idem.
} 
no lide com o gado. ${ }^{119}$ Havia uma forte hierarquia entre estes trabalhadores. $\mathrm{O}$ principal agente era o criador dos bovinos. Dono do rebanho, delegava temporariamente as tarefas na fazenda a algum empregado ou parente de confiança para acompanhar com seus próprios olhos o árduo e moroso trabalho de condução. Quando o dono não era o principal responsável pela viagem, a chefia ficava sobre a responsabilidade de um condutor. Podia ser um homem livre ou escravo, na maioria das vezes funcionário da própria unidade produtiva da qual o gado era originário. Havia também os condutores alugados que eram pagos pelo dono da boiada para cumprir a tarefa de passar o rebanho e coordenar o trabalho dos outros funcionários empregados na mesma atividade de condução.

\section{Gráfico 2}

Entrada de gado na Feira: Destino final das boiadas (1784-1789)

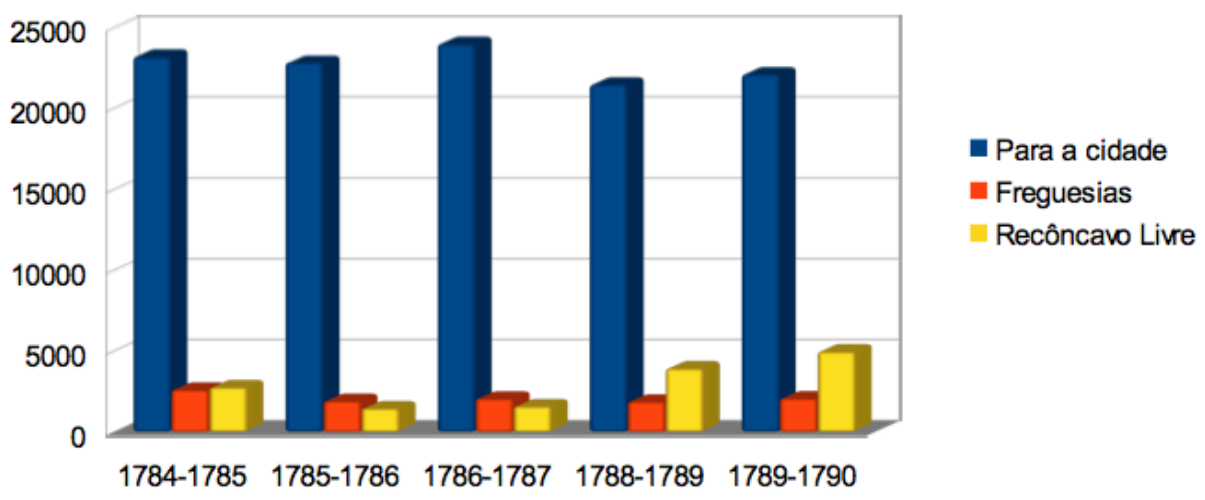

Fonte: "Livros de Registro de Entrada de Gado" da feira de Capuame (1784-1789)

Em alguns casos, na ausência do criador do rebanho, a condução ficava sob responsabilidade de um cativo. Quando o condutor era escravo, podemos conjecturar que os outros homens que o acompanhavam também o fossem. Tudo isso porque é de se supor que fosse difícil para uma sociedade

119. A documentação mais elaborada e rica em informações sobre o processo de condução das boiadas sertanejas certamente são os relatórios sobre as fazendas do Fisco Real estabelecidas na capitania do Piauí. As diversas unidades produtivas faziam parte da herança deixada pelo sertanista Domingos Afonso Sertão aos padres jesuítas. Quando da expulsão dos membros da Companhia de Jesus das possessões portuguesas, as fazendas de gado foram confiscadas e passaram a ser administradas pela Real Fazenda. A produção anual dos criatórios deviam ser obrigatoriamente conduzidos para a feira de Capoame acompanhada por uma descrição detalhada do nome dos passadores responsáveis e dos demais homens trabalhadores no transporte do gado. AHU_CL_CU_016, cx.11, d. 646, d. 656, d. 666, d. 669, d. 693, d. 700. Oficio do Governador do Piaui, Goncalo Botelho de Castro, ao governador e capitao-general, Joao Pereira Caldas, sobre a devolucao do dinheiro do rendimento das fazendas pertencentes as capelas instituidas por Domingos Afonso Sertao. 1773, janeiro 16, AHU_CL_CU_016, cx.12, d. 707; AHU_CL_CU_016, cx.12, d. 717. Oficio do governador do Piaui, Goncalo Botelho de Castro, ao secretario de Estado da marinha e Ultramar, Martinho de melo e Castro, sobre o rendimento dos bens dos jesuitas, de 1773 a 28 de abril de 1774, e remetendo uma relacao dos animais que foram enviados para a a Bahia, 1774, julho 22. Entre outros. Capitania do Piauí. 
amplamente hierarquizada por critérios de cor e condição jurídica, o cargo de maior confiança ficar sob a responsabilidade de um cativo enquanto tivesse outros homens na condição de livres incumbidos de executar o mesmo trabalho. Pouco provável que eles se subordinariam ao escravizado por uma questão de hierarquia social reproduzida inclusive nas estradas.

Segundo os "Livros de Registro de Entrada de Gado" da feira de Capuame, referentes aos anos de 1784 a 1789, das 1945 entradas de boiadas vindas dos sertões baianos, 37,8 \% foram levadas até a feira por criadores, 60,5 $\%$ por condutores livres e $1,7 \%$ por condutores escravos. ${ }^{120}$ Decerto os dados não são absolutamente confiáveis na medida em que várias denúncias de fraudes eram feitas aos vereadores da Câmara Municipal de Salvador (em especial quando se tratavam dos criadores), visto ser corriqueiro os atravessadores de beira da estrada comprar o gado antes de chegar na feira por um preço muito abaixo do mercado e se dizerem os autênticos donos e produtores sertanejos do rebanho. ${ }^{121}$

No que diz respeito à condução das boiadas sertanejas, depois do primeiro lugar na hierarquia ocupado pelo criador ou pelo condutor, havia a presença dos tangedores, dos guias e por último dos cargueiros. Estes trabalhadores eram em sua maioria escravos. Nenhum deles era nomeado nos "Livros de Registro de Entrada de Gado", havendo somente referência a eles nos documentos das Fazendas da Administração Real da capitania do Piauí. ${ }^{122}$ Apareciam também como testemunhas nos livros em que se fazia o registro das reses mortas pelos caminhos entre a feira de Capuame e o matadouro público da cidade de Salvador, assinando sempre em cruz. ${ }^{123}$ Podiam ser alugados ou ser funcionários da fazenda onde o gado conduzido fora criado. Muitos dos ocupantes dos cargos mais baixos possivelmente eram escravos novos, até mesmo crianças, devido a agilidade requerida pelo ofício e por aprenderem desde muito cedo o trabalho. ${ }^{124}$ Os guias e tangedores iam cuidando para as reses não se desviarem do caminho. Alguns tomavam a dianteira do comboio, especialmente nos momentos de travessia de rios. Os cargueiros eram responsáveis por carregar toda a parafernália necessária para uma viagem. Mantimentos, água, armas, munição eram imprescindíveis para as longas jornadas. Possivelmente o privilégio de seguir todo o percurso montado

120. AMS. "Livros de Registro de Entrada de Gado" da feira de Capoame (1784-1789)

121. APEB. Correspondência recebida pelo governo. Senado da Camara da Bahia (1783-1799). Maço 201-14. 13 de setembro de 1797; APEB. Senado da Camara de Salvador Correspondência recebida (1786 - 1822). Maço 485-2. 14 de abril de 1804. fl. 26 e segs.

122. Todas as referẽncias às boiadas vindas das fazendas da Administração Real da Capitania do Piauí foram citadas na nota de roda-pé número 106.

123. AMS. Livro de "Justificação de reses mortas" (1791-1811) sub-secção: Matadouro.

124. Um dos mandigueiros presos pelo Tribunal do Santo Ofício em Jacobina tinha dezesseis anos. Luiz Mott. "Quatro mandigueiros do sertão da Jacobina nas garras da Inquisição". Bahia: Inquisição e Sociedade. Salvador, 2010, p. 121-169. Jozé Norberto Macedo observa que muitos dos guias, "guieiros" ou "candieiros" eram meninos, crianças, em geral filhos dos vaqueiros ou carreiros. Jozé Norberto Macedo. Fazendas de Gado no vale do São Francisco. Rio de Janeiro 1952, p. 55. 
em cavalos era dado somente aos criadores e condutores. Os demais homens que compunham o comboio certamente seguiam a pé. ${ }^{125}$

A média de boiadas que chegavam à Capuame semanalmente variava muito conforme a época do ano. A estação chuvosa no sertão vai dos meses de outubro a março. Caso chovesse muito por aquelas bandas, o transporte das boiadas ficava prejudicado, sendo difícil a travessia de rios e córregos, atrasando a chegada do gado. Para a feira de 29 de novembro de 1786 temos o registro de que :

"Fica em caminho hua Boyada por conta do rio não chegou a feira, em chegando entrará para dentro; e na feira vindoura hirá encluida na guia o compito com que chegar. Mandei entrar os gados de pastorador, que já foram em guias."126

A época de seca era entre os meses de março e outubro. Durante o período, regiões inteiras chegam a nível pluviométrico nulo. Através dos "Livros de Registro de Entrada de Gado", é possível fazer uma levantamento da movimentação das boiadas pela feira de Capuame para o período de 1784 a 1789, sendo possível observar uma relativa regularidade de abastecimento, com exceção dos momentos mais delicados de grandes secas ou grandes chuvas: 127

\section{Gráfico 3}

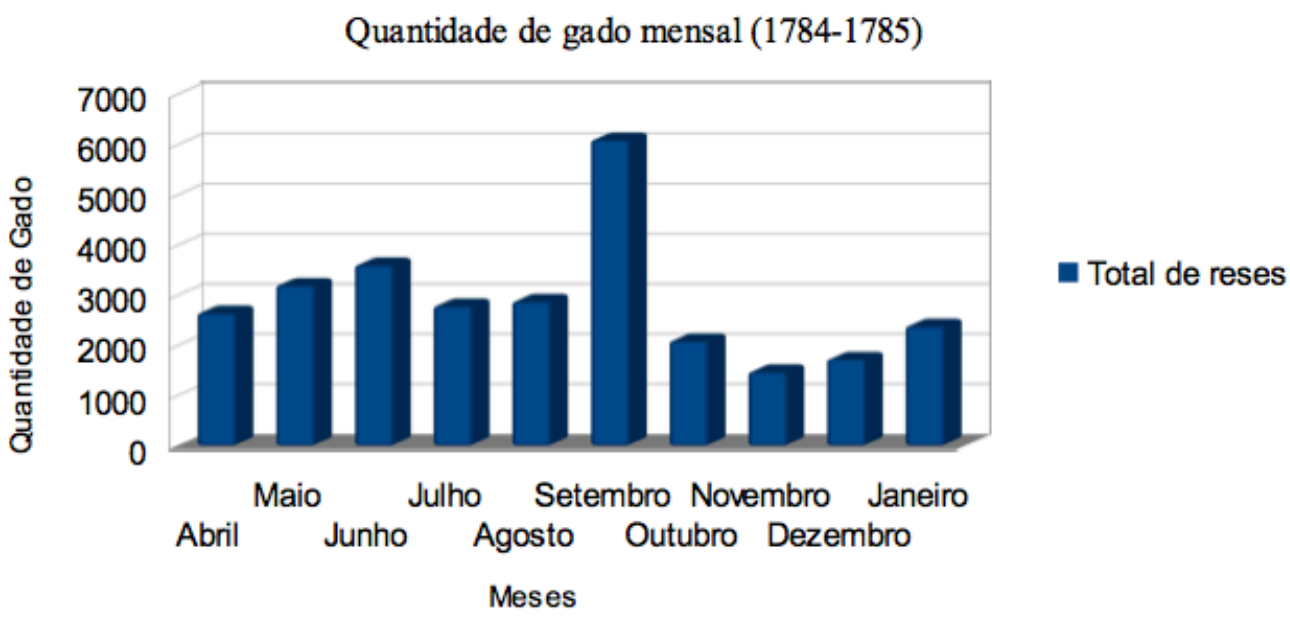

Fonte: "Livros de Registro de Entrada de Gado" da feira de Capuame (1784-1789)

\footnotetext{
125. Os pormenores referentes ao trabalho nas fazendas dedicadas à produção de gado vaccum e a condução das boiadas serão tratados com mais detalhes no segunda capítulo da dissertação.

126. AMS. "Livro de Registro de Entrada de Gado" (1784-1789). fl. 125v.

127. As grandes chuvas eram um problema para o abastecimento desde o século XVII. Em 1679, os senadores reclamam dos prejuízos que têm nos momentos de chuva, visto nas épocas de invernada os rios caudalosos inundarem, impossibilitando o comércio e condução das boiadas resultando na morte de reses e feitores. A necessidade de criação de pontes para sanar as dificuldades sempre foi uma solicitação corriqueira mais pouco executada. AMS, "Cartas do Senado (1673-1684)", volume 2, 15 de julho de 1679, p. 51.
} 


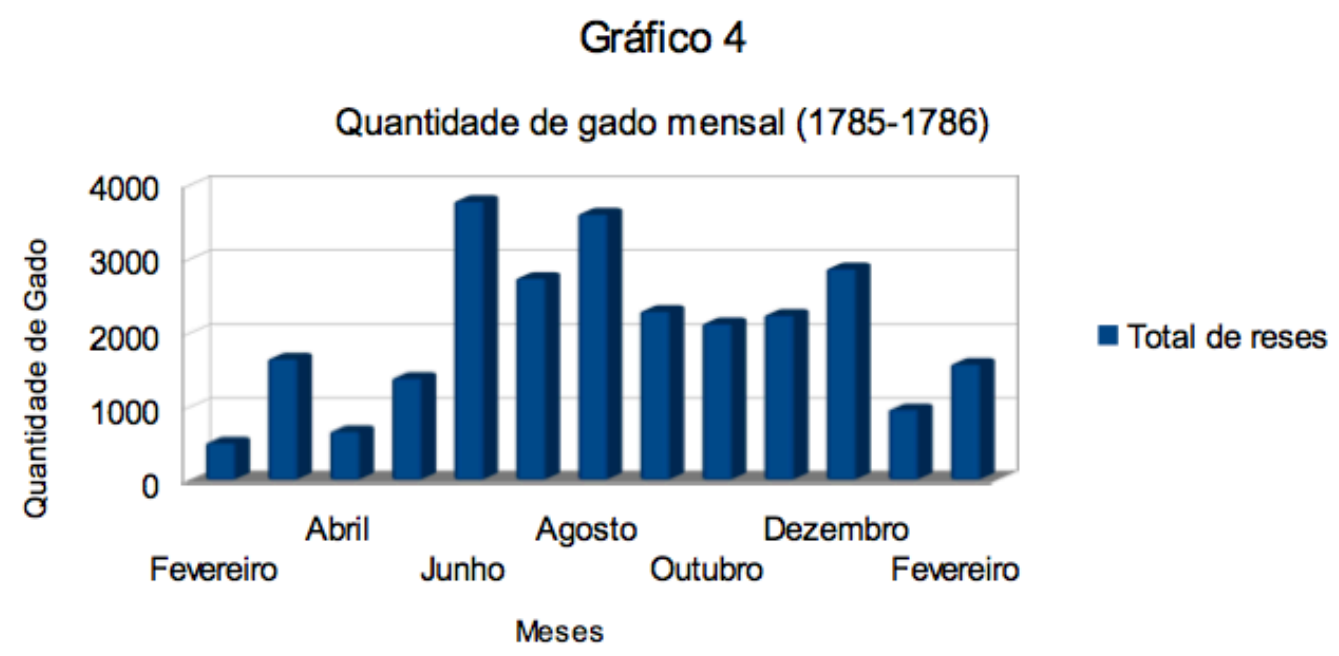

Fonte: "Livros de Registro de Entrada de Gado" da feira de Capuame (1784-1789)

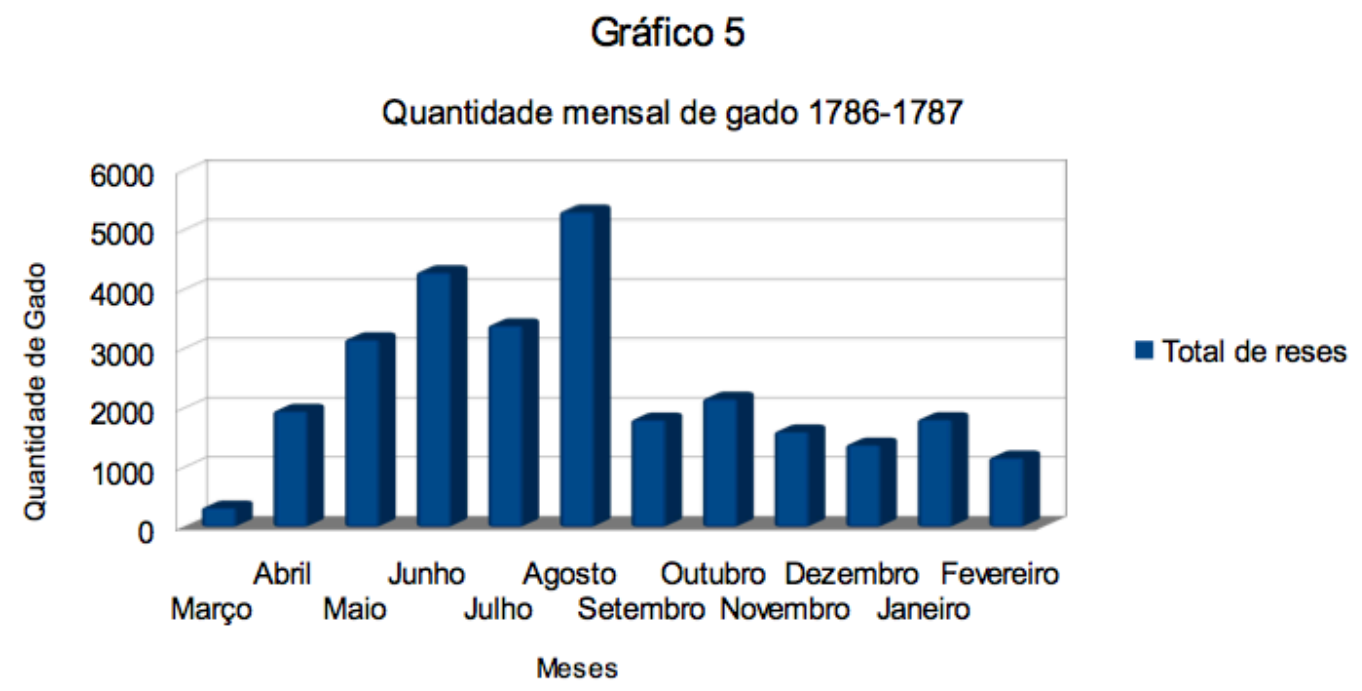

Fonte: "Livros de Registro de Entrada de Gado" da feira de Capuame (1784-1789) 


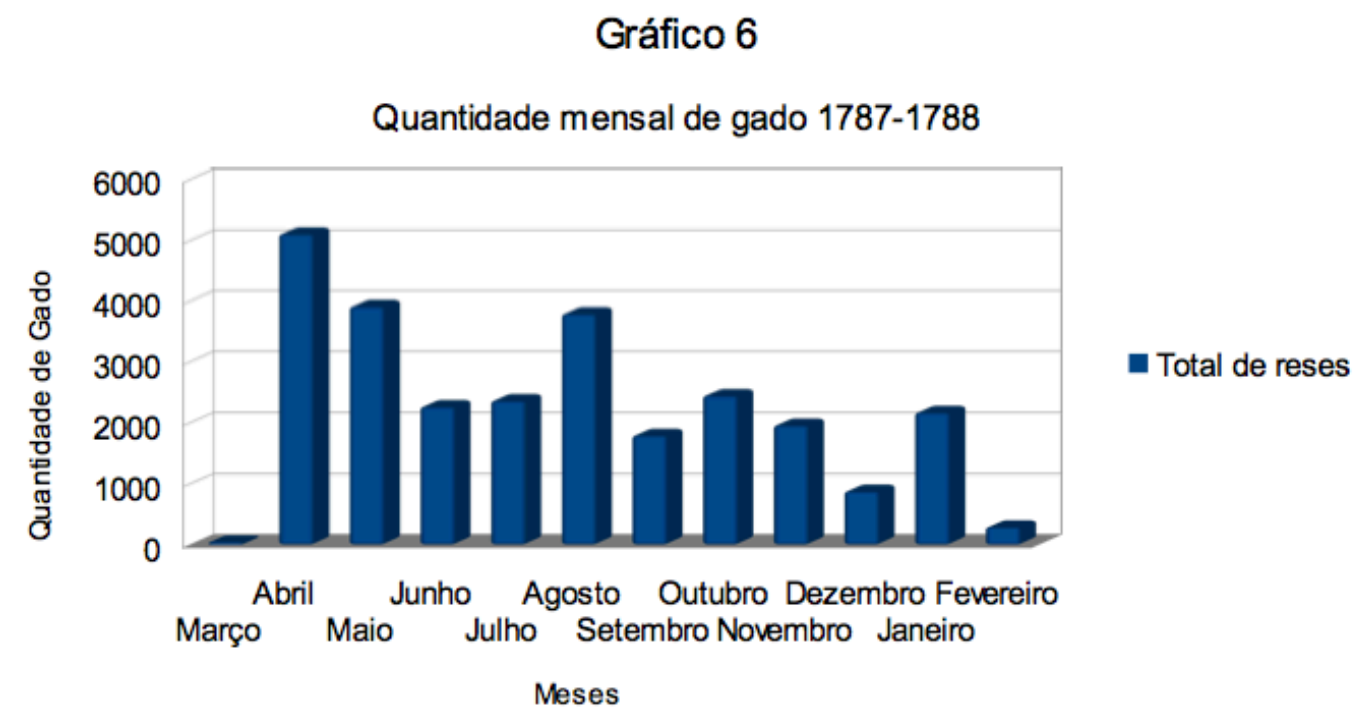

Fonte: "Livros de Registro de Entrada de Gado" da feira de Capuame (1784-1789)

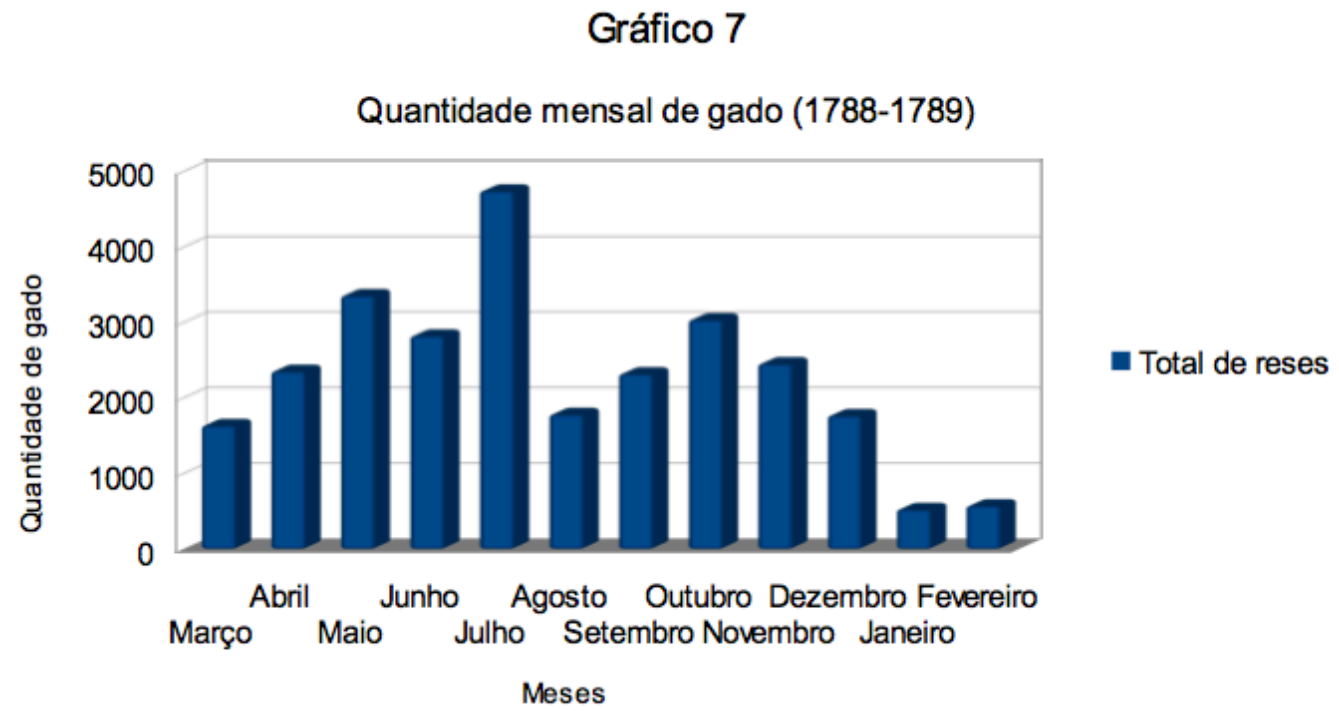

Fonte: "Livros de Registro de Entrada de Gado" da feira de Capuame (1784-1789) 


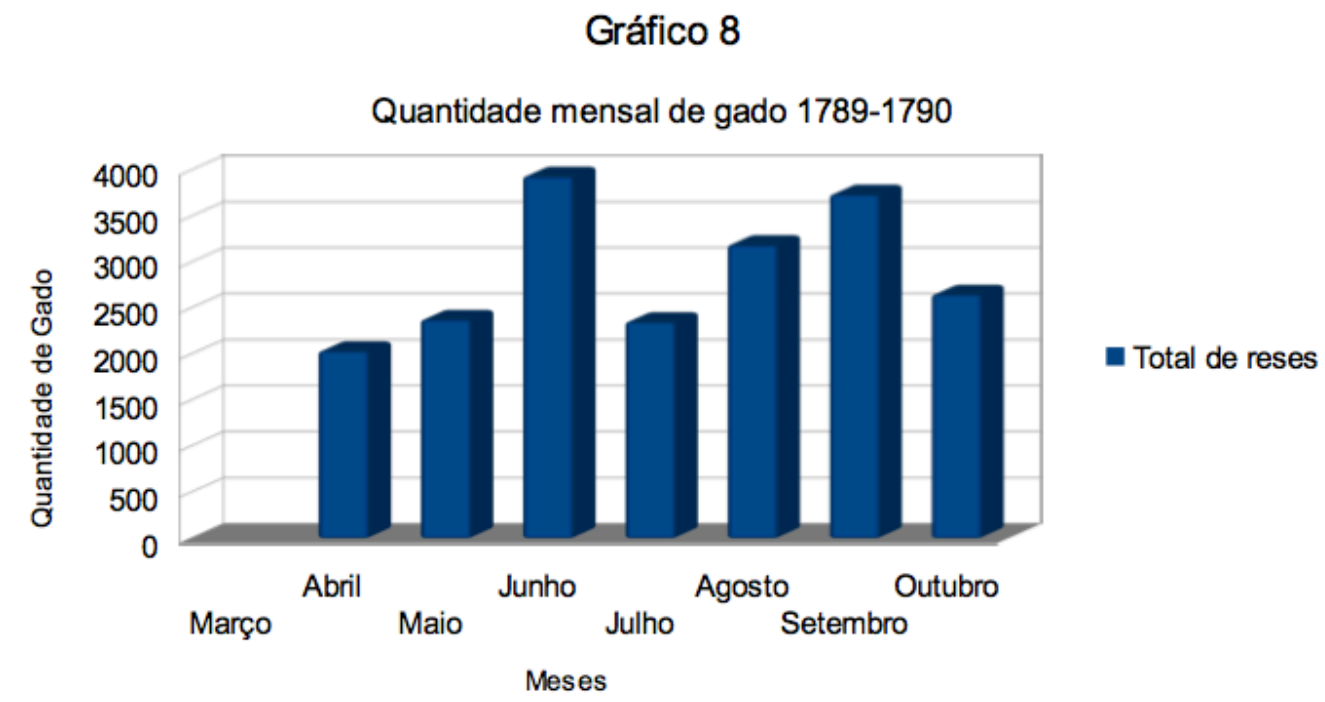

Fonte: "Livros de Registro de Entrada de Gado" da feira de Capuame (1784-1789

Assim como pode ser observado no primeiro gráfico apresentado, os "Livros de Registro de Entrada de Gado" da feira de Capuame traziam sempre como informação de alta relevância para a administração pública o destino final das boiadas sertanejas. Oficialmente os rebanhos poderiam ter três destinos possíveis: a cidade de Salvador, as freguesias suburbanas e as cidade de Recôncavo. Todavia a prioridade era sempre o centro políticoadministrativo da capitania. Outras regiões só receberiam reses que passassem por Capuame caso houvesse um elevado índice de entrada de gado pelo registro atingindo uma somatória acima da necessária para o abastecimento da população soteropolitana.

A primeira informação que chama a atenção nos dados levantados através do "Livro de Registro de Entrada de Gado" da feira de Capuame é a existência de ao menos um mês de pico de encaminhamento das boiadas por ano. Este pico ocorria impreterivelmente nos meses de estação seca. Possivelmente esta época era escolhida pelo fato dos caminhos serem mais facilmente transitáveis, fugindo de atoleiros e grandes trombas d'águas capazes de pegar os condutores e o rebanhos de surpresa na hora da travessia dos rios existentes nos caminhos.

Os momentos de maior chegada das boiadas na feira de Capuame ocorriam em geral na metade do ano. Quando analisados mais detalhadamente os dados da composição dos rebanhos destes momentos de pico de encaminhamento é curioso observar que elas coincidem com a condução dos grandes rebanhos vindos dos sertões do Piauí. Gurguéia, Canindé, Itaim, entre outros foram os sertões citados como os locais de origem das maiores boiadas que chegavam praticamente no mesmo mês em Capuame, formando estes picos de entrada de gado. 
É muito provável que o período de encaminhamento dos bovinos formadores das maiores boiadas fosse seguido por algum momento de estiagem. O mês exatamente posterior ao período anual de maior movimento na feira de Capuame é marcado por uma baixa muitas vezes abrupta, perceptível no gráfico produzido para alguns anos de dados disponíveis. Quando estes meses são observados mais de perto, com base no "Livro de Registro de Entrada de Gado", é possível reparar que não há necessariamente uma diminuição no número de boiadas encaminhadas à Capuame. Em geral, é perceptível que o fator decisivo para marcar a diferença está vinculada a quantidade de reses de cada rebanho encaminhado. Há uma diminuição significativa na composição de cada boiada que inclusive vem menos da região dos sertões além São Francisco, como é o caso dos sertões do Piauí, e passa a vir mais dos sertões de dentro próximos a Tucano, Itapicuru, dentre outros pontos de criação localizados na margem direita do rio São Francisco.

Daqui derivam alguns dados importantes sobre algumas características gerais da pecuária dos sertões baianos. Primeiramente, o padrão para as grandes unidades produtivas era possivelmente o envio de grandes boiadas uma vez ao ano. No caso de fazendeiros que possuíam mais de um grande curral, ocorria do intervalo entre os encaminhamentos ser menor, contando com mais de um rebanho enviado para a feira de Capuame, como era o caso do gado produzido nas fazendas do sertão do Porto da Folha pertencentes ao senhor de engenho Antonio Gomes Ferrão Castelo Branco. ${ }^{128}$ Difícil confirmar se o caso retratado era de fato a regra.

É possível fazer uma média levando em consideração o tamanho dos rebanhos mais bem documentados. Para esta finalidade só temos como parâmetro de comparação as boiadas das fazendas da Administração Real do Piauí - confiscada dos jesuítas no momento da expulsão - que estavam muito longe de ser a regra. Para o ano de 1782 um inventário dos bens certifica que nas três inspeções ${ }^{129}$ havia um total de 50.670 bovinos. No mesmo ano foi registrada a saída de sete boiadas com destino a feira de Capuame, compostas no total por 1.954 reses. Ou seja, 3,8\% do total do rebanho foi deslocado aquele ano para o mercado. Caso levemos este dado em consideração, poderíamos dizer que para enviar anualmente à Capuame uma boiada de 100 reses, um criador precisava ter um rebanho médio de 2.500 reses, o que certamente não era a realidade da maior parte dos sertanejos. Sendo assim, logo de saída já chegamos a conclusão que só era viável aos grandes produtores de gado o encaminhamento anual de boiadas para abastecer o mercado consumidor litorâneo.

Os médios e pequenos produtores que insistiam em vender o seu rebanho, certamente não eram capazes de compor uma boiada somente com o gado criado em sua unidade produtiva ou nas terras de outrem. As longas distâncias, a alta mortalidade dos bois e vacas pelos caminhos tornava

\footnotetext{
128. Antonio Gomes Ferrão Castelo Branco. Borrador em que lanço todas as cartas que escrevo, principiado em agosto de 1742, estando na Babia. São Paulo, Coleção Mindlin. Transcrito por Rosana Gonçalves sob orientação da Profa Dra Mary Del Priore e gentilmente cedido pelo Prof. Dr. Istvan Jancsó

129. Repartições administrativas internas às fazendas do Fisco Real.
} 
impraticável a condução de pequenos rebanhos. Por outro lado, para uma quantidade razoável de criação de um mesmo dono, não vender os animais significava a possibilidade de perda total no momento de uma grande seca. Para tornar praticável o comércio do gado, possivelmente deviam juntar bovinos de mais de um dono e encaminhar sob os cuidados de um vaqueiro ou passador de confiança. As dívidas arroladas em inventários post mortem certificam a existência de acordos entre criadores e boiadeiros de outras unidades produtivas sobre a comercialização de um rebanho encaminhado para o litoral. No livro Borrador de Antonio Gomes Ferrão Castelo Branco também é possível observar que em alguns casos os vaqueiros do Porto da Folha traziam bovinos pertencentes a senhores diferentes. ${ }^{130}$ No próprio "Livro de Registro de Entrada de Gado" da feira de Capuame é possível perceber uma rotatividade enorme do nome daqueles que entravam com as boiadas sertanejas, com exceção dos membros da elite baiana que encaminhavam rebanhos com uma frequência surpreendente, além de serem isentos do imposto cobrado no registro de entrada de gado. Trataremos deste assunto com mais detalhes a seguir.

Os dados dos "Livros de Registro de Entrada de Gado" da feira de Capuame torna observável o baixo encaminhamento de reses no período da Quaresma. Entre os meses de fevereiro e março a quantidade de gado conduzido até Capuame podia ser quase nula. Aqui duas explicações são capazes de dar conta do fenômeno. O primeiro deles está intimamente ligado a uma lógica de sociedade pautada e organizada pelo calendário cristão. Segundo as diretrizes da Igreja Católica, o período de Quaresma era marcado pelo resguardo. Lembrando do período em que Jesus Cristo esteve pelo deserto, passando por momentos de privação de alimentos, era recomendado aos fiéis guardarem o período santo, mantendo o jejum de determinados alimentos, dentre eles a carne. Especificamente na Semana Santa, a ingestão de carne era terminantemente proibida, configurando como pena de sacrilégio àquele que não obedecesse as normas da Santa Igreja. ${ }^{131}$

O segundo motivo para que os meses de fevereiro e março fossem marcados por um baixo encaminhamento de boiadas estava vinculado a questões climáticas. Estes meses coincidiam com o final das estações chuvosas. Levando em consideração que a condução das boiadas demorava algumas semanas ou meses para se efetivar por completo, possivelmente os criadores e trabalhadores preferissem esperar o momento de estiagem. Com certeza, este "cálculo" quanto ao melhor período para o encaminhamento, estava ligado ao aumento abrupto de fluxo entre os meses de junho e setembro. É razoável pensar que depois das chuvas, os criadores preferissem aproveitar os pastos para esperar o boi engordar. As estradas precisavam estar menos úmidas e os rios, menos caudalosos.

130. Borrador em que lanço todas as cartas que escrevo, principiado em agosto de 1742, estando na Babia. São Paulo, Coleção Mindlin. Transcrito por Rosana Gonçalves sob orientação da Profa Dra Mary Del Priore e gentilmente cedido pelo Prof. Dr. Istvan Jancsó

131. Dom Sebastião Monteiro da Vide. Constituições Primeiras do Arcebispado da Babia. (Impressas em Lisboa no ano de 1719, e em Coimbra em 1720. São Paulo): Tip. 2 de Dezembro, 1853. p. 163 
Então, depois de alguns meses aguardando o melhor momento para conduzir os rebanhos sertanejos pelas estradas e caminhos abertos em meio a caatinga, chegava o período ideal para o encaminhamento: aquele subsequente ao primeiro momento de estiagem, mas necessariamente antes dos sertões estarem muito secos a ponto de faltar água para ajudar no deslocamento dos animais. Esta devia ser a regra para os rebanhos criados nas paragens mais distantes, como era o caso do gado dos sertões do Piauí. As paragens mais próximas do litoral conseguiam ter uma certa flexibilidade nos momentos de encaminhamento, podendo executar a viagem em uma época mais extensa. Mas certamente os criadores preferiam aproveitar as condições mais propícias para conduzir a parte da produção que era voltada para o mercado. Não correriam o risco de perder uma boiada inteira caso fossem pegos de surpresa por uma forte estiagem.

Nos "Livros de Registro de Entrada de Gado" da feira de Capuame apareceu algumas vezes a informação sobre o gado vindo "para suprir a cidade". Esta era uma descrição utilizada pelo escrivão para especificar a quantidade de gado que algum militar ou funcionário nomeado havia trazido diretamente das fazendas sertanejas em momento de carestia. Interessante notar que este tipo de informação só apareceu em três momentos específicos da feira. Na semana do dia 20 de fevereiro de 1788 entraram três pequenas boiadas contendo respectivamente oito cabeças conduzidas por Thomé Pereira, sete por Florêncio Rocha e onze encaminhadas por Antonio Cardozo. Na semana do dia 16 de abril de 1788 foi a vez de entrar Roque Pinto com 116 bovinos e por fim no dia 30 de abril de 1788 entrou na feira de Capuame o marchante Manoel JESUS do Bonfim com 79 reses para suprir a cidade. $O$ fato de todos os registros sobre falta de gado serem referentes ao ano de 1788 pode ser um indicativo que naquele ano houve problemas com o abastecimento do gênero.

Calculando somente o número de homens sertanejos vindos juntos com as boiadas que chegavam todas as semanas, era possível contar com uma quantidade média de cem forasteiros todas as quartas-feiras em Capuame. Isso sem falar dos demais comerciantes e viandantes que aproveitavam o grande movimento no local para também fazer eventuais negociações com outros produtos. Toda essa gente reunida criava a necessidade do estabelecimento de lugares para dormir, montar acampamento ou permanecer em pousos, comer e passar o tempo enquanto não recebiam ordens para pegarem novamente a estrada. Daí o motivo de surgimento das vendas, pousos, tavernas e outros pontos comerciais nos arredores da movimentada feira. 
QUADRO 1: Comparação entre a quantidade de reses encaminhadas em cada mês (Safras anuais de 1784-1789)

\begin{tabular}{|l|l|l|l|l|l|l|}
\hline & $\mathbf{1 7 8 4 / 1 7 8 5}$ & $\mathbf{1 7 8 5 / 1 7 8 6}$ & $\mathbf{1 7 8 6 / 1 7 8 7}$ & $\mathbf{1 7 8 7 / 1 7 8 8}$ & $\mathbf{1 7 8 8 / 1 7 8 9}$ & $\mathbf{1 7 8 9 / 1 8 0 0}$ \\
\hline Março & - & 1653 & 328 & 40 & 1628 & 0 \\
\hline Abril & 2646 & 663 & 1957 & 5102 & 2346 & 2034 \\
\hline Maio & 3198 & 1389 & 3160 & 3908 & 3349 & 2375 \\
\hline Junho & 3607 & 3784 & 4292 & 2258 & 2819 & 3934 \\
\hline Julho & 2783 & 2743 & 3397 & 2356 & 4737 & 2351 \\
\hline Agosto & 2873 & 3611 & 5317 & 3787 & 1774 & 3191 \\
\hline Setembro & 6094 & 2297 & 1810 & 1788 & 2312 & 3738 \\
\hline Outubro & 2094 & 2129 & 2162 & 2440 & 3030 & 2648 \\
\hline Novembro & 1465 & 2245 & 1609 & 1953 & 2445 & - \\
\hline Dezembro & 1726 & 2871 & 1388 & 873 & 1759 & - \\
\hline Janeiro & 2385 & 964 & 1814 & 2162 & 522 & - \\
\hline Fevereiro & 509 & 1581 & 1171 & 285 & 569 & - \\
\hline
\end{tabular}

Fonte: "Livros de Registro de Entrada de Gado" da feira de Capuame (1784-1789)

Levando em consideração a quantidade de escravos formadores de cada um dos comboios responsável por encaminhar as boiadas sertanejas e o número de forasteiros e vendedores ambulantes que passavam por aquelas paragens era de se supor que a vigilância das autoridades fosse bem constante. Soldados e homens de patente faziam diariamente a ronda da feira, para evitar que aquela gente pertencente a "ínfima plebe" provocasse algum tipo de desordem em um dos principais pontos de arrecadação da renda da Câmara Municipal de Salvador. ${ }^{132}$

Quando as boiadas chegavam à Capuame, elas ficavam em currais mais ou menos próximos da casa da superintendência e do registro de entrada, dependendo do movimento e número de boiadas que chegassem naquela semana. O registro de entrada do gado só acontecia nas quartas-feiras. Dia oficial de funcionamento da feira, passagem das boiadas e consequente encaminhamento direto para a cidade de Salvador. A casa da superintendência era o prédio público no qual trabalhavam o superintendente, escrivão, tesoureiro e os demais funcionários da feira de Capuame. Segundo o processo criminal aberto em 1806 para averiguar a tentativa de assassinato de André Corcino da Silva (descrito no início do presente capítulo), na casa de

132. Mais detalhes sobre a segurança e a quantidade de homens de patentes que fazia a ronda na feira serão expostos na segunda parte do presente capítulo. 
superintendência funcionava também uma cadeia. Possivelmente lá as autoridades mantinham encarcerados todos os infratores que seriam posteriormente transferidos para a capital. ${ }^{133}$

$\mathrm{Na}$ medida em que a região onde estava localizada a feira de Capuame era cercada por fazendas e sítios, pertencentes na maioria dos casos aos comerciantes locais e até mesmo aos marchantes, era comum que algumas boiadas ficassem "empastouradas" naquelas unidades produtivas circunvizinhas. Isto ocorria somente nos momentos de grande concentração de boiadas na feira ou quando a quantidade de reses estipulada para abastecer a cidade da Bahia de Todos os Santos já tinha sido atingida, ou seja, 250 cabeças de gado semanais para o ano de 1734. ${ }^{134}$ Quando isso acontecia, cabia ao superintendente observar a veracidade da informação e ao escrivão, documentar os dados no "Livro de Registro de Entrada de Gado". Deveria constar a quantidade de reses que ficavam estacionadas fora da feira, o nome da fazenda ou sítio, o dono do local, assim como o nome do dono do gado. Estas rezes "empastouradas" precisavam já ter pago o imposto e tinham preferência para serem conduzidas nos momentos de grande necessidade. Como mencionado anteriormente, elas apareciam nos "Livros de Registro de Entrada de Gado" com os dizeres: "para suprir a cidade."

Antonio Lopes, por exemplo, aparece como marchante nos "Livros do Registro de Entrada de Gado", mas também como possuidor de uma fazenda na Feira de Capuame em que às vezes deixava gado à solta. João do Rego Gomes também era um marchante que possuía a Fazenda do Trapixe na qual deixava gado "empastourado". Outra pessoa bastante mencionada nos documentos referentes à pecuária e comércio de carne é o Capitão Cristovão da Rocha Pitta ${ }^{135}$, que também parece ser proprietário de pastos próximos à região de Capuame. Além destes, ainda temos a Fazenda Quiricó do Tenente Pedro Caetano, Fazenda da Moita de Felix Barboza, Fazenda do Capitão Jozé Maria, Fazenda do Emboassica do Alferes Domingos Dias, Fazenda de Manoel Gonçalvez no Campo, Sítio da Capema, Fazenda de Vasco Marinho, Fazenda de Eugênio Dias na Mata, entre outros. ${ }^{136} \mathrm{Em} 30$ de junho de 1784, foi concedido ao marchante Constantino Alves da Cruz o direito de comprar todo o gado residual que aparecesse na feira para deixar pastando nas fazendas Capuame e Bandeira, onde trabalhava também como administrador, cujo proprietário era João Francisco da Costa. Argumentava que no mês depois de setembro era comum haver falta de reses para abastecer Salvador por não descerem dos sertões quantidade suficiente, pedindo assim a permissão dos funcionários da Câmara Municipal de Salvador para poder manter o gado em

\footnotetext{
133. APEB. Câmara para o Governador, 12 de março de 1806, maço 209-1, doc. 108.

134. Certamente o cálculo do gado necessário para abastecer semanalmente a feira aumentou durante o século XVIII. Todavia, não foi possível localizar a informação para outros momentos. DH. "Portaria para o Capitão Luiz Pereira de Almeida" 11 de outubro de 1734. Vol. 76, p. 13.

135. Membro destacado da elite baiana, o inventário do Capitão Cristovão da Rocha Pitta não foi localizado no APEB embora tivesse sido mencionado e analisado no trabalho de doutorado da Prof. Dra. Maria José Rappassi Mascarenhas. Fortunas Coloniais: elite e riqueza em Salvador (1760-1808). USP, São Paulo, 1999.

136. AMS. "Livro de Registro de Entrada de Gado" da feira de Capuame (1784-1789).
} 
regime de engorda nas fazendas que administrava e descê-lo para capital assim que fosse iniciado o momento crítico da carestia. ${ }^{137}$

Depois das boiadas já instaladas nos currais da feira, lá iam os marchantes ao encontro dos criadores e condutores para tratar de negócios. Separavam as reses que queriam comprar, acertavam o valor com o dono ou representante do dono. Possivelmente, no caso dos condutores, o poder de barganha era menor, na medida em que já deviam sair das fazendas sertanejas com orientações dos donos do gado sobre o valor que os pecuaristas queriam em suas mãos.

Interessante notar que Capuame não era uma feira livre propriamente dita. A peculiaridade da feira de Capuame estava na impossibilidade de haver um livre acesso ao produto lá comercializado. Não era permitido a qualquer pessoa que chegasse à feira comprar tranquilamente uma quantidade determinada de gado em pé e voltar para seu lar puxando uma ou duas vacas amarradas com um pedaço de corda. A compra dos animais era altamente fiscalizada, sendo concedida licença somente aos marchantes que possuíam autorização municipal para poderem atuar no ofício. E mesmo assim, o ato de comprar o gado não era simplesmente baseado na quantidade em dinheiro "de contado" ou em crédito que o marchante possuía no momento da feira, permitindo que levasse ao matadouro público o número de cabeças que bem entendesse. Cálculo difícil (ainda não muito bem compreendido, devido as inúmeras alterações e aos possíveis acordos pessoais feitos entre os marchantes), a quantidade destinada a cada um deles dependia do número de reses que tivessem entrado naquela semana.

Observando os "Livros de Registro de Entrada de Gado" é possível perceber que os marchantes saíam quase sempre com uma quantidade semelhante de animais da feira de Capuame a cada semana. Se a quantidade de reses não fosse semelhante, ela era pelo menos proporcional. A repartição dos talhos, ou seja, a quantidade de reses que o marchante tinha o direito de encaminhar da feira de Capuame aos açougues públicos da cidade para serem abatidos e depois vendidos, nem sempre era feita igualitariamente, apesar do número destinado a cada um ser aproximado. Havia alguns casos em que um marchante ou outro tinha direito a uma quantia maior de bovinos. Fazia parte da negociação algum tipo de jogo de proporção que possivelmente pressupunha acordo prévio entre os marchantes, os funcionários da feira e da Câmara Municipal. Os motivos e as regras dos trâmites são dificilmente mapeados pois certamente baseava-se em acordos internos, feitos de modo informal e não escrito, entre os negociantes que compareciam semanalmente na feira para exercer seu ofício.

Transcrevo a partir de agora o conteúdo de uma carta potencialmente esclarecedora - se não fosse enigmática - sobre o regime de partilha. Evidente que a carta só foi produzida pois na ocasião houve problemas com o tradicional acordo firmado. $\mathrm{O}$ motivo da desavença estava na proteção e

137. APEB. Senado da Câmara de Salvador. Correspondência expedida ao governo (1789). Maço 4851. 30 de junho de 1789, fl. 25. 
benefício corriqueiro que a Câmara dava aos criadores que levassem por conta própria o gado para ser cortado em Salvador, sem intermédio dos marchantes, posto muitos deles não pagarem no tempo hábil o valor acordado pela compra da boiada, causando grande prejuízo aos criadores. ${ }^{138}$ Todavia, os marchantes alegavam que os pretensos criadores eram na verdade afamados atravessadores. Independente da fraude já mencionada anteriormente, aqui importa entender o sistema de partilha das reses na feira de Capuame entre os diferentes talhos da cidade, a ordem e a lógica como era pensado tal procedimento.

"Senhores do Senado,

Dizem José Francisco de Aragão, João Antonio da Fonseca e Ignacio de Santo Antonio marchantes do número desta cidade que da repartição dos talhos que se fez sábado sete do corrente mês de abril resulta aos suplicantes muito prejuízo porque devendo-se dar ao primeiro suplicante três talhos, ao segundo, [um] talho e meio e ao terceiro outros três talhos se conferiram somente dois ao primeiro, um ao segundo e dois ao terceiro além de serem estes dos mais fracos que há na repartição pelo que ficaram lesados como se mostra no extrato junto, a trinta e cinco cabeças para cada um talho dos conferidos e pelo contrário se viu no dos condutores sendo escolhidos dos mais possantes tem para cada um o que no mesmo extrato se mostra e porque esta desigualdade pode ser proveniente de fingir que são criadores legítimos e mereceram por isso preferência mas se mostra o contrário pois os suplicados protegidos não são criadores sim atravessadores que morando uns na Mata de São João e outra na estrada da Jacobina atravessam os gados que vem de primeira ou segunda mão e não achando quem os compre para o Recôncavo, depois de venderem às cabeceiras aos forminas vem a feira [da Capuame] com os que lhe fica na deligência de venderem aos suplicantes [os marchantes] por altíssimos preços e não lhe comprando ainda vendem aos forminas assim como praticaram na semana antecedente dois que venderam um dezoito cabeças que registrou na Feira e outro quarenta e cinco, e voltando para seus domicílios nem apareceram no curral a pagar os direitos nem sabe o administrador de quem os há de haver condição esta que não milita com os suplicantes habilitados por este Senado com fiadores idôneos a responsabilidade dos direitos do Conselho e da Real Coleta e ao produto dos mesmos gados que comprarem na Feira ou fora dela além de rematarem anualmente as faculdades de que tem resultado as rendas avultadas do conselho vinte e tantos contos de réis nos vinte anos que tem corrido como se pode mostrar por conta feita e sendo assim os suplicantes [marchantes] é que devem ser mais atendidos na repartição dos talhos e não os suplicados atravessadores.

Bahia, 14 de abril de 1804.

Para Vossas Senhorias sejam servidos emendar sem [sic] enganando, mandando que na repartição dos talhos sejam mais atendidos os suplicantes dando-se mais talhos para venderem as suas carnes e não os suplicados protegidos que são atravessadores e não criadores como é bem público e muito constante.

Extrato que se mostra a repartição que o Senado fez de 23 talhos para 540 cabeças das quais tem cada indivíduo o número como abaixo vai notado, a saber: 


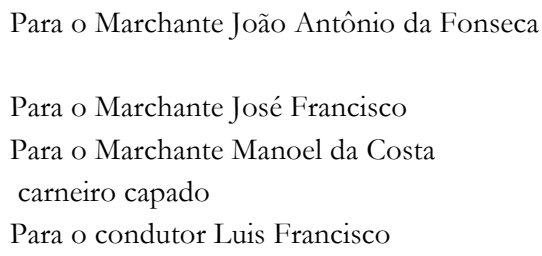

$\begin{array}{ll}5^{\circ} \text { de Santo Antonio } & 3 \\ 1^{\circ} \text { de São Bento } & 3 \\ 2^{\circ} \text { de São Bento } & 3 \\ 6^{\circ} \text { de Santo Antonio } & 35 \\ 3^{\circ} \text { Praya } & 25 \\ 25 & 5 \\ 2^{\circ} \text { Santo Antonio } & 2 \\ 7^{\circ} \text { de Santo Antonio } & 2 \\ \text { Presas }^{\circ} \text { São Bento } & 1 \\ 7^{\circ} \text { São Bento } & 1 \\ 1^{\circ} \text { Praya } & 17 \\ \text { Rell m [sic] } & 22 \\ 2^{\circ} \text { da Praya } & 22 \\ 4^{\circ} \text { Praya } & 22 \\ 5^{\circ} \text { Praya } & 22 \\ 6^{\circ} \text { Praya } & 217 \\ 7^{\circ} \text { Praya } & 21 \\ 8^{\circ} \text { Praya } \\ 1^{\circ} \text { Santo Antonio } \\ 3^{\circ} \text { São Bento } \\ 5^{\circ} \text { São Bento } \\ \text { [total] }\end{array}$

Sendo repartidos os 23 talhos pela regra de proporção como sempre se tem praticado cabe a cada um 23 cabeças e meia e tocaria a 73 talhos e a 35 talhos e meyo."139

De acordo com o documento, as 540 reses foram repartidas em 23 talhos, ou seja, em 23 partes não necessariamente iguais distribuídas entre oito homens destinadas a cinco lugares distintos de comércio da carne abatida e cortada no matadouro público. Neste caso específico, os talhos divididos entre os suplicantes e os pretensos criadores estavam localizados sobretudo nos açougues públicos de São Bento, Santo Antonio e da Praia. Interessante notar a deslocada referência aos carneiros capados. Será que eles também vinham através da feira de Capuame? Será que eram pertencente a produtores sertanejos que aproveitavam a estrutura da feira para comercializar estes animais? Para o século XVII foi possível perceber a existência de contratos de arrematação produzidos exclusivamente para regular e garantir o corte e comércio da carne de porco. ${ }^{140}$ Passavam pela região de Capuame? Eram produzidos nos arrebaldes da cidade? Difícil saber.

O talho da Relação devia ser àquele destinado a abastecer os ministros e desembargadores do Tribunal da Relação da Bahia. O talho das presas possivelmente era alguma referência a um presídio ou clausura destinado a mulheres religiosas. As conjecturas param por aqui. Fora a certeza de que cada açougue era abastecido por mais de um marchante, não sabemos como se dava o jogo da proporção que cabia a cada um. Por que os dois primeiros marchantes arrolados no documento acima citado saíram da feira de Capuame com 70 cabeças de gado e o terceiro marchante somente com a metade, ou

139. APEB. Senado da Camara de Salvador Correspondência recebida (1786 - 1822). aço 485-2. 14 de abril de 1804. fl. 26 e segs.

140. Ver: AMS. Livros de Contratos de Arrematação. 
seja, 35? O documento não explica. Infelizmente, nem tudo nos é facultado entender.

Nas economias de Antigo Regime chama atenção a proibição corriqueira da existência de intermediários e atravessadores. Ou seja, os comerciantes que compravam nas portas das unidades produtivas para venderem a mercadoria por um preço maior nos centros urbanos eram considerados elementos prejudiciais ao bem público e executores de fraude. ${ }^{141} \mathrm{Na}$ feira de Capuame não era diferente: somente os criadores e condutores legítimos podiam trazer as boiadas sertanejas semanalmente. Mas quem conferia a veracidade das declarações orais? Fora o fato de conhecer alguns atravessadores mais persistentes e frequentadores assíduos da feira pessoalmente, era difícil saber se o rebanho pertencia realmente ao criador ou condutor declarado. Poderíamos supor que houvesse algum tipo de registro das marcas de ferro de cada rês, mas o controle sobre este tipo de identificação era praticamente impossível. Muitas dívidas eram acertadas com bois; bovinos pertencentes a mais de um pequeno produtor certamente eram juntados para formar uma boiada viável de ser conduzida por longas distâncias. Encaminhar uma boiada com menos de cem cabeças - dependendo da distância - certamente configurava-se como algo anti-produtivo. No limite, qualquer pessoa que se declarasse condutor ou criador conseguia vender as reses na feira de Capuame. O mesmo não ocorria com a saída do gado em direção a cidade de Salvador. O controle e rigorosidade em relação a venda do gado era enorme. Fora os criadores e condutores que levassem por conta própria o rebanho até o matadouro com autorização prévia do governador, os donos de engenho e religiosos que eram isentos do imposto sobre gado, somente os marchantes licenciados podiam comprar as reses. Daí resulta a diferença observada nos "Livros de Registro de Entrada de gado" entre aqueles que entram com as reses e aqueles que saem com os animais.

Nos "Livros de Registro de Entrada" de Gado da Feira de Capuame para os anos de 1784 e 1789 é curioso reparar primeiramente na divisão esquemática entre as boiadas que entravam e as boiadas que saíam do único espaço em que a comercialização era permitida. O número de cabeças de gado constante em cada um dos dois grupos deveria ser exatamente igual. Tudo deveria ser documentado. O mesmo número de gado que entrasse em uma determinada semana precisava ter o seu destino final muito bem especificado. Se fossem guiados por marchantes até o matadouro, se fossem encaminhados para os engenhos do recôncavo, se iam servir para a matalotagem das Naus das Índias ou dos funcionários da feira: pouco importava, contanto que os dados fossem todos anotados detalhadamente e condissessem com as diretrizes básicas da dinâmica de funcionamento da feira de Capuame.

Das boiadas que entravam semanalmente em Capuame, é fácil notar a variedade de nome de criadores e condutores registrados. Vários podem ser os motivos para tal rotatividade. Um grande produtor em geral mandava à feira

141. Fernand Braudel, Civilização material, economia, capitalismo (séculos XV-XVIII), São Paulo, 2009, vol. 2 (Os jogos das trocas), p. 34. E.P. Thompson, Costumes em Comum. São Paulo, 1998, p. 156. 
um de seus funcionários como condutor responsável pela boiada. Possivelmente nem sempre era o mesmo condutor responsável por assumir a dianteira do trabalho em todas as viagens saídas de uma mesma unidade produtiva. Esse é o caso facilmente mapeável do senhor de engenho e grande fazendeiro Cristovão da Rocha Pitta. Os criadores Vitorio de Souza, João Fereira, o condutor Antonio João do sertão do Rio de São Francisco, o condutor Capitão Domingos Roiz' do sertão do Rio de Baixo, os condutores João Pires, João da Rocha, Antonio Teyxeira do sertão do Itaim, os criadores Dizidério Pereira, Capitão Florentino de Almeida Pereira e o condutor Lauriano de Almeida do sertão do Pajahú [Pajeú], o condutor Jozé de Torre do sertão do Piauí são alguns dos homens mencionados como responsáveis pela condução das boiadas pertencentes ao capitão Cristóvão da Rocha Pitta. ${ }^{142}$ Sabemos quando a boiada pertencia a ele pois em geral o escrivão fazia questão de registrar a informação além de ser comum que um de seus escravos fosse o responsável pelo rebanho. Quando era o escravo o condutorchefe da jornada, fazia-se sempre necessário descriminar nos documentos produzidos pelo escrivão de Capuame qual era o nome do dono do cativo. Possivelmente o escravo apresentava algum documento que comprovasse ser o gado pertencente ao seu dono ou a um fazendeiro que o tivesse contratado, além de algum tipo de identificação pessoal que impedisse o cativo de ser confundido com um fugitivo.

Ainda é necessário fazer um levantamento mais cuidadoso sobre a movimentação de criadores e condutores na feira de Capuame, traçar o perfil dos envolvidos com o comércio do gado em pé. Por ora, é interessante notar que algumas figuras da elite, grandes fazendeiros e criadores aparecem com uma frequência enorme, quando comparados ao número de homens que passaram somente uma vez em Capuame. Certamente muitos dos pequenos produtores não possuíam unidades produtivas voltadas única e exclusivamente para abastecer o mercado, conduzindo reses somente em momentos específicos. É possível também que os pequenos e médios produtores vendessem as reses para terceiros, pedissem para um vaqueiro ou condutor encaminhar seu pequeno rebanho juntamente com a boiada principal ou juntassem mais de um rebanho na hora de comercializar, explicando assim a quantidade múltipla de produtores que passavam esporadicamente como o criador ou condutor responsável pelo rebanho.

A mesma rotatividade não aparece entre os responsáveis pelas boiadas que saíam da feira de Capuame em direção a Salvador. Já foi mencionado que os criadores e condutores podiam eventualmente pedir licença aos funcionários da Câmara Municipal para cortar a carne às suas custas diretamente no açougue, sem precisar negociar as reses com os marchantes, afamados caloteiros. ${ }^{143}$ Fora estas licenças, a regra era a condução e encaminhamento feito pelos marchantes atuantes na feira. E aqui o número é sempre muito reduzido de homens devidamente regulamentados e atuantes no

142. AMS. "Livro de Registro de Entrada de Gado" da feira de Capuame (1784-1789).

143. APEB. Maço 159. Carta do governo a várias autoridades (1787-1802). "Para Dezembargador Ouvidor Geral do Crime." 23 de maio de 1793. 
ofício de negociantes de gado. Para o período de 1784 a 1789, eram quarenta os marchantes licenciados para exercerem o ofício. Nem todos atuaram concomitantemente. Mesmo para os períodos anteriores, o número sempre foi extremamente reduzido. Daí também o fato dos marchantes serem figuras que apareciam semanalmente às feiras. Toda santa quarta-feira lá estavam eles negociando boiadas. Privilégio para poucos.

Mas privilégio mesmo eram as exceções, ou melhor, as concessões feitas à regra geral. Uma parte dos "Livros de Registro de Entrada de Gado" era preenchida exclusivamente com o nome de todas as pessoas que receberam a mercê de não pagarem pelo imposto sobre o gado em pé. O donativo era fixado em $\$ 500$ (quinhentos réis) por cabeça, impreterivelmente quitados na hora do registro da boiada, em dinheiro "vivo". Todavia, uma dúzia de privilegiados conseguiam ser isentos da taxação, mediante a apresentação de uma singela carta de deferimento assinada pelo governador da capitania. Novamente, o nome dos contemplados com a graça eram sempre os mesmos e pouquíssimos, comparados com o universo de moradores e senhores de Salvador e arredores. Todos eles tinham em comum o fato de serem grandes senhores de terras e gente. Tanto no sertão quanto no litoral. Eram donos simultaneamente de engenhos e fazendas de gado vaccum. Casos concretos foram as isenções concedidas aos irmãos Cristovão, Thomé Lançarote e Antonio da Rocha Pitta (citados praticamente em todas as semanas), ao engenho do "Mestre de campo da Torre", aos donos do engenho da Mata, engenho da Pitanga, engenho de São João, engenho de São Paulo, engenho Novo de Cotegipe. Engenhos de Curnubusu, Jacaracanga, Pirajá, Paripe. Para a fazenda de Dona Rita Xavier, engenho de Dona Maria da Vargas, Dona Ana Maria Lacerda. Capitão Vitorino de Argollo, Mestre de Campo Miguel Jerônimo Argollo, Antonio Teixeira Barbosa (senhor do engenho da Passagem) e Antonio Gomes Ferrão Castelo Branco (senhor do engenho Mombaça e herdeiro do solar do Unhão). Senhor de engenho João Francisco da Costa, Capitão José Luis da Roxa Dorea, o fazendeiro Dr. Adriano Antunes, capitão Manuel Oliveira Barrozo ${ }^{144}$, Francisco José Duarte, João Tavares. Vez ou outra também apareciam alguns padres e religiosos, como por exemplo, reses para Senhor do Bonfim, as reses encaminhadas com certa frequência para as religiosas do Convento da Soledade, engenho dos religiosos do Carmo, fazenda do Padre José Ferreira de Andrade ou para o Padre Manoel Rodrigues.

Os pedidos de isenção e licença para encaminhar gado diretamente ao Recôncavo baiano aparecem já nas primeiras décadas do século XVIII e um dos principais argumentos para a licença ser concedida era o solicitante ser um reconhecido dono de unidades produtivas que necessitasse das reses e bois mansos para manter a fábrica funcionando. 145 Motivo "nobre" se não fosse

\footnotetext{
144. Senhor do engenho Aratu, morador da freguesia de Nossa Senhora do Ó de Paripe, no Recôncavo Baiano, teve seis filhos pardos com a escrava jeje Luzia Gomes de Azevedo . Adriana Dantas Reis Alves. As mulberes negras por cima: o caso de Luiza jeje. Escravidão, família e mobilidade social Babia, c.1780 - c.1830 . Niterói, 2010.

145. AMS. Ofícios do governo (1712-1737).
} 
diagnosticado que o critério da concessão não era somente este. $\mathrm{O}$ privilégio era dado preferencialmente à elite de produtores. Possivelmente àqueles que possuíam uma quantidade maior de escravos, maior volume de produção e certamente um sobrenome influente. Sabendo que os Familiares do Santo Ofício também contavam com o privilégio de serem isentos de uma série de impostos, é possível que alguns dos fazendeiros que deixavam de pagar pela entrada do gado na feira de Capuame fossem ligados diretamente à Inquisição. ${ }^{146}$

Religiosos e funcionários régios também possuíam privilégio na hora do acesso à carne verde. Como será visto com maiores detalhes no terceiro capítulo, os religiosos tinham um açougue à parte do restante da população. ${ }^{147} \mathrm{Os}$ ministros do Tribunal da Relação chegaram a solicitar o benefício de terem também um espaço próprio para cortarem a carne que consumiam. ${ }^{148} \mathrm{Nas}$ reclamações sobre os problemas de abastecimento, moradores da cidade de Salvador alegaram que os membros da elite mandavam seus escravos para comprar carne nos açougues e eram atendidos com preferência em relação aos demais. Um açougue particular foi cedido como uma regalia aos Irmãos da Santa Casa de Misericórdia, ${ }^{149}$ reproduzindo até mesmo nas atitudes mais corriqueiras, tais como a compra diária de alimentos, as hierarquias sociais e os privilégios concedidos a um pequeno grupo de homens. Essa é a definição de elite.

Quanto ao comércio executado por poucos marchantes em Capuame, um dos maiores problemas e motivos de conflitos nas feiras semanais era o fato de que nem sempre a venda se liquidava na hora. O que prevalecia de fato na feira de Capuame era o crédito. Possivelmente a forma e o prazo para o pagamento era firmado através de acordos verbais, como era costume entre muitos negociantes da época. ${ }^{150}$ Como "as pessoas felizes não tem história", 151 várias são as reclamações referentes aos marchantes que não pagavam as dívidas contraídas com os criadores de gado, forçando os sertanejos a passarem semanas às suas próprias custas nos arredores da feira ou da cidade

\footnotetext{
146. Eram constantes as reclamações da população e dos vereadores quanto aos privilégios concedidos aos oficiais do Santo Ofício, ficando somente os pobres responsáveis por toda a carga tributária. AMS. Cartas Do Senado (1638-1673), volume 1, p. 35.

147. Camila Teixeira Amaral. As duas Espadas do Poder: As relações de tensão e conflito entre o poder secular e o poder eclesiástico na Babia (1640-1750). UFBA, Salvador, 2012.

148. AMS. Atas da Camara (1700-1718). "Termo de vereação e de resolução que se tomou sobre os talhos dos desembargadores." vol. 7,16 de maio de 1703. p. 161.

149. AMS. Atas da Camara (1700-1718). "Termo por onde se concedeu o açougue Misericórdia”. 11 de agosto de 1706. vol. 7, p. 298.

150. Sobre as noções de crédito para os comerciantes do século XVIII, ver: Raphael Freitas Santos. Devo que pagarei: sociedade, mercado e práticas crediticias na comarca do Rio das Velhas - 1713-1773, UFMG, Belo Horizone, 2005.

151. Frase irônica de Fernand Braudel ao falar sobre o crédito, as bancarrotas, na medida em que os documentos sobreviventes e os processo abertos sobre as transações comerciais serem sempre referentes à dívidas não pagas, calotes. Ninguém escreve ou reclama de um negócio bem sucedido. Fernand Braudel, Civilizaçãa material, economia, capitalismo (séculos XV-XVIII), São Paulo, 2009, vol. 2 (Os jogos das trocas).
} 
de Salvador, esperando por receber o dinheiro e poder voltar satisfeito para o sertão.

Em Ata da Câmara de 10 de abril de 1767, os vereadores comentaram os grandes malefícios que estavam cometendo os marchantes: além de pagarem aos criadores o preço que bem entendiam no gado, não ajustavam as dívidas no tempo acordado, fazendo com que os sertanejos e todos os seus ajudantes passassem semanas na cidade ou em Capuame esperando o dinheiro, colocando esse povo em desespero. Quando cansavam de esperar, voltavam para casa com as mãos abanando, cheios de explicações lamuriosas, gerando um ciclo vicioso: os criadores evitavam vender o gado para os marchantes que por sua vez não conseguiam receber o suficiente para saldar as dívidas, além de padecer a população pela demora no encaminhamento de uma nova boiada. ${ }^{152}$

Em 23 de maio de 1793, por exemplo, dois marchantes foram presos ao tentarem embarcar em uma sumaca na freguesia da Conceição da Praia com destino a capitania de Pernambuco, "após darem o calote nos criadores de gado vindos negociar suas boiadas na feira de Capuame"153 Por essas e outras histórias, muitas foram as licenças concedidas aos criadores para cortar carne nos açougues por conta própria. Nestes casos, eliminava-se o intermédio dos marchantes, fazendo com que os próprios criadores ou condutores seguissem com a boiada registrada em Capuame até o açougue público onde eles mesmos davam entrada no pedido de corte dos talhos. Entre os ofícios e requerimentos da Câmara Municipal de Salvador há uma quantidade significativa de pedidos sem data. Luís da Costa Agra, através de seu passador, Antonio Gomes de Mattos, solicitou a concessão de talhos dos açougues prometidos aos criadores para cortar por conta própria as 290 reses que remetera de suas fazendas do sertão de Rodelas. O mesmo pedido aparece em nome de Mathias Rodrigues Fao do sertão de Itapicuru e do Padre Dom Abade dos Mosteiros de São Bento, também dono de fazenda de gado. ${ }^{154}$

Depois da negociação e venda das boiadas aos marchantes - ou a decisão do criador de encaminhar por conta própria o gado para algum açougue em Salvador - era a vez de esperar pela quarta-feira da semana. Esse era o dia de abertura do registro de entrada de gado da feira de Capuame. A sequência de registro das boiadas respeitava inteiramente a ordem de chegada na feira. $\mathrm{Na}$ casa da superintendência, sob presença do superintendente, escrivão e tesoureiro, o marchante ou o criador declaravam o número de reses que iriam passar para a cidade de Salvador e pagavam a quantia de $\$ 500$ (quinhentos réis) por cabeça. O pagamento deveria ser feito obrigatoriamente em dinheiro. Até o momento não foi possível saber qual das partes envolvidas nos negócios tinha a obrigação de pagar o imposto. Talvez este fosse um ponto de negociação entre os produtores e os comerciantes. ${ }^{155} \mathrm{Na}$ perspectiva da

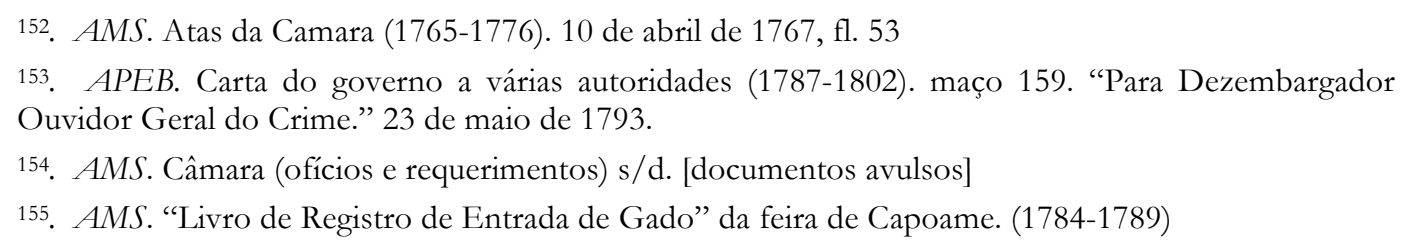


fiscalidade, isso não importava. Saber quem pagaria pelo donativo era o de menos. O importante era que ele fosse pago.

No final do século XVIII e sobretudo durante o século XIX, foram criados outros registros de entrada de gado como mais uma tentativa de inibir ou ao menos diminuir a atuação dos atravessadores e contrabandistas sempre presentes nas estradas e arredores da feira. Os registros de entrada de gado ficavam em Cajueiro ${ }^{156}$, Santana dos Olhos d'Água157, Campina, ${ }^{158}$ Queimadas, Saco de Moura159, Serrinha, Lagoinha, Tamboatá160. Um registro de Passagem também encontrava-se instalado na Passagem do Juazeiro no rio São Francisco. Todos eles foram implementados nos caminhos que ligavam os sertões à feira de Capuame. Em cada um dos registros, o criador ou condutor da boiada deveria mostrar uma guia contendo a quantidade de reses que encaminhava. Não podia faltar nenhuma cabeça. Caso aparecesse uma quantidade menor, era preso pela acusação de desvio e contrabando. Se alguma rês morresse pelo caminho devia apresentar declaração explicando o ocorrido contendo juramento e testemunhas. ${ }^{161}$

Da feira de Capuame até o curral público de Salvador, os criadores, condutores e marchantes iam acompanhados por militares devidamente armados. Seguiam pela Estrada das Boiadas até chegar a uma das portas da cidade. Nos currais e matadouro também precisavam apresentar novamente uma guia assinada pelos funcionários da feira de Capuame constando a quantidade de reses com que saíram do registro.

Não foi para todos os anos de funcionamento da feira que conseguimos fazer um mapeamento (nem mesmo aproximativo) do rendimento do comércio de gado para os cofres públicos da cidade de Salvador, na medida em que ainda não foram localizadas as cartas emitidas pelos superintendentes aos governadores-gerais contendo os róis de entrada das boiadas. Para a década de 1780 e 1790 foi possível montar um quadro com base nas informações constantes nos "Livros de Registro de Entrada de Gado" da feira de Capuame e nas correspondências trocadas entre o governador e os vereadores da Câmara Municipal de Salvador.

O fim do ano fiscal (no que dizia respeito ao comércio de gado) ocorria na Quaresma, fechando o ciclo na semana da Páscoa. Sendo assim, a "safra" de carne era calculada entre uma Semana Santa e outra, ou seja, o cômputo de

\footnotetext{
156. AMS. "Livro de Partes e Ofícios da Administração da Feira". (1801-1810); AMS, Circulares da Camara (1726-1819). 31 de julho de 1805.

157. Na fazenda Santana dos Olhos D'Água, ponto de contrabando, depois transformada em Feira de Santana. AMS. "Livro de Partes e Ofícios da Administração da Feira". (1801-1810)

158. Campina do Pirajá, ficava no atual bairro do Pirajá, no meio da estrada das boiadas. AMS. Posturas Municipais (1829-1859). Lei de 1 de outubro de 1828. Artigo 3.

159. Atual municípo de Serrinha. APEB. Correspondência recebida pelo governo. Senado da Camara da Bahia (1783-1799) maço 201-14. 4 de junho de 1794.

160. Cajueiro, Lagoinhas, Saco de Moura, Serrinha e Tamboatá foram citado como registro existentes em 1792 contando cada qual com a vigilia de um capitão-mor. APEB. Correspondência recebida pelo governo. Senado da Camara da Bahia (1783-1799). 13 de setembro de 1797

161. AMS. Livro de "Justificação de rezes mortas" (1791-1811) sub-secção: Matadouro.
} 
1790 correspondia a todo o imposto coletado depois da Páscoa de 1789 até o período da Quaresma de 1790. Referente aos dados sobre o imposto coletado, há três possibilidades e tipos diferentes de informações que coincidem. Uma delas faz menção à quantidade de gado registrado na feira de Capuame e ao cálculo do pagamento de $\$ 500$ (quinhentos réis) por cabeça de gado entre os anos de 1784 e 1789. O outro cálculo diz respeito à quantidade de reses cortadas nos açougues públicos em cada um dos anos entre 1790 e 1796 pagando o imposto de $\$ 480$ (quatrocentos e oitenta réis) por arroba talhada. Salvo uma rês ou outra que morria no caminho, o cálculo das duas repartições era basicamente o mesmo, tornando-se possível mensurar o movimento de gado entre a feira de Capuame e o açougue a partir da junção dos dois conjuntos de dados, na medida em que somados são capazes de cobrir o período correspondente aos anos de 1785 a 1796. Fora os dois cálculos supracitados, é possível também ter uma base de comparação da movimentação do gado através da "Lista dos manifestos da coleta literária imposta nas carnes" produzida em 4 de setembro de 1799. Esta lista foi usada para mensurar a quantidade de gado para os anos de 1790, 1797 e 1798. No terceiro capítulo será melhor explicado os detalhes sobre a arrecadação do "Subsídio Literário", criado em 1772 com o objetivo de cobrir os gastos com a educação e o pagamento de salários dos professores após a "Reforma dos Estudos" proposta pelo Marquês de Pombal. O importante aqui é saber que o "subsídio literário" era um imposto que incidia principalmente sobre a carne verde cortada nos açougues de Salvador.

Difícil manter uma base de comparação do registro de entrada de gado estabelecido na feira de Capuame em relação aos outros registros espalhados pela América Portuguesa. Primeiramente porque faltam inclusive dados para a quantidade de gado que passava pela feira de Capuame nas primeiras décadas em que funcionou o registro de entrada de gado. Para os anos posteriores a 1795, mesmo que haja documentos sobre a feira, tais como os "Livros de Registro de Entrada de Gado" produzidos na primeira década do século XIX, alguns deles são de difícil sistematização pela sua própria lógica de preenchimento pouco afeita a uma organização mais voltada para a contabilidade dos rendimentos do registro. Muitos dos livros não possuem um cálculo geral do número de bovinos negociados em cada dia da feira. Mesmo que um pesquisador insistisse em arrolar os dados, para alguns anos tal tarefa está integralmente comprometida devido o estado de conservação dos documentos. Eles simplesmente despedaçam conforme são manuseados. 
QUADRO 2: Quantidade de gado em pé conduzido de Capuame à Salvador e Recôncavo(1785-1789)

\begin{tabular}{|c|c|c|c|c|c|}
\hline Data & $\begin{array}{r}\text { Cidade em } \\
\text { guia }\end{array}$ & Freguesias & $\begin{array}{r}\text { Recôncavo } \\
\text { Livre }\end{array}$ & Mortas & Total \\
\hline 9 de março de 1785 & 23.208 & 2.590 & 2.747 & - & 28.545 \\
\hline 6 de abril de 1786 & 22.819 & 1.905 & 1.441 & - & 26.165 \\
\hline 7 de abril de 1787 & 23.990 & 2.043 & 1.566 & 619 & 28.218 \\
\hline 22 de fevereiro de 1788 & 21.453 & 1.864 & 3.909 & - & 27.226 \\
\hline 18 de fevereiro de 1789 & 22.082 & 2.057 & 4.960 & - & 29.099 \\
\hline 3 de março 1790 & $20.068^{*}$ & - & - & - & - \\
\hline 2 de abril de 1791 & 18.772 & - & - & - & - \\
\hline 14 de março de 1792 & 23.269 & - & - & - & - \\
\hline 27 de fevereiro de 1793 & 15.781 & - & - & - & - \\
\hline 29 de março de 1794 & 17.053 & - & - & - & - \\
\hline 17 de fevereiro de 1796 & 17.388 & - & - & - & - \\
\hline 1797 & $16.989 *$ & - & - & - & - \\
\hline 1798 & $20.565 *$ & - & - & - & - \\
\hline
\end{tabular}

Fonte: $A P E B$. Correspondência recebida pelo governo. Senado da Camara da Bahia (17831799). Maço 201-14. 3 março de 1790, 14 de março de 1792, 27 de fevereiro de 1793, 29 de março de 1794, 17 de fevereiro de 1796, 13 de setembro de 1797.

Para as capitanias do sul, há referência dos registros de entrada de mercadorias estabelecidos em Curitiba, Sorocaba, Santa Vitória e Viamão. Segundo Tiago Luís Gil, em 1751 foram registradas 9.502 cabeças de gado em Curitiba. ${ }^{162} \mathrm{O}$ pesquisador cita também as informações constantes no trabalho de Martha Hameister no qual entre “os anos de 1769, 1770 e 1771 registrariam, respectivamente, 9.710, 9.651 e 10.915 cabeças, entre mulas, bois, vacas e cavalos, com notória predominância numérica destes últimos". "Para o ano financeiro de 1779/80, contaram 2.365 cavalos, 6.330 muares e 5.720 vacuns, somando 14.415 animais; 1780/81 registraria 14.945 peças e 1781/82 outras 15.778 , sempre com predomínio vacum, que atingiu $54 \%$ nesta última

*. Os dados para os anos de 1790, 1797 e 1798 foram baseados na "Lista da Manifesto da coleta literária imposta as carnes". 4 de setembro de 1799.

162. Tiago Luís Gil. Coisas do Caminho. Tropeiros e seus negócios do Vaimão à Sorocaba. (1780-1810),Rio de Janeiro, UFRJ, 2009, p. 45. 
leva."163 Lá pagava-se o imposto de \$240 réis por cabeça de gado vaccum. Para a década de 1790, o autor não menciona o número total de bovinos registrados, mas segundo os gráficos há uma nítida preponderância da passagem de muares, estando os bovinos ainda entre o total de 5 a 7 mil animais comercializados. Interessante notar que o trabalho de Martha Hameister demonstra justamente que no século XVIII a maior parte dos animais direcionados a região de São Paulo e Minas Gerais eram mulas e sobretudo cavalos, constando poucos bovinos entre as criações destinadas a abastecer as capitanias mais centrais. ${ }^{164}$

Para a cidade do Rio de Janeiro, conseguimos ter acesso aos dados produzidos pelos responsáveis pelo Matadouro público. Segundo Pedro Henrique Pereira Campos, em 1812 foram mortas 41.600 reses e 50.050 no ano de $1821.165 \mathrm{O}$ gado em pé vindo por terra passava pelos registros de Sorocaba e Lorena. Do Rio Grande do Sul vinham reses vivas, mas principalmente charque ${ }^{166}$. A viagem podia demorar até dois meses, tendo cada boiada uma média de 400 reses no século XIX. Difícil fazer uma comparação direta com a entrada de gado da feira de Capuame pela falta de simultaneidade das informações. Todavia, já era de se supor que após o ano de 1808, com o crescimento vertiginoso da nova capital da América Portuguesa depois da vinda da família Real, o comércio de carne ultrapassasse sem dúvida aquele observado na capitania da Bahia.

Interessante notar que foram localizadas poucas informações sobre o comércio de carne seca para a capitania da Bahia. Através de estudo monográficos é possível saber que havia uma grande produção de carne seca nas capitanias do Norte tais como o Ceará e Rio Grande. Leonardo Cândido Rolim, em "Tempos das carnes" no Siará Grande demonstra a importância das fábricas de carne seca estabelecidas na Vila de Santa Cruz do Aracati, responsáveis pelo abate e salga de 16.000 reses em média por ano, para abastecer Recife e Bahia. ${ }^{167}$ Ao que tudo indica, a Bahia dedicava-se mais a produção de gado em pé dependendo da carne-seca provinda de outras regiões para alimentar parte da população, tais como os escravos. De acordo com o relato do senhor de engenho Antonio Gomes Ferrão Castelo Branco, era preferível alimentar os escravos e trabalhadores livres do Engenho Mombaça com carne seca por ser mais barata que a carne fresca vinda das fazendas sertanejas. O único inconveniente da carne seca é ter de ser comprada

163. Idem, p. 47.

164. Martha Daisson Hameister. O Continente do Rio Grande de São Pedro: os homens, suas redes de relaçoes e suas mercadorias semoventes (c. 1727 - c. 1763). Rio de Janeiro, 2002.

165. Pedro Henrique Pereira Campos. Nos caminhos da acumulação. Negócios e poder no abastecimento de carneverde para a cidade do Rio de Janeiro (1808-1835). São Paulo, 2010, p. 11.

166. Interessante o adendo feito por Leonardo Cândido Rolim sobre o uso do termo charque ser encontrado somente para as capitanias do sul, na medida em que a palavra deriva da língua Quíchua, dos índios ocupantes da região platina. Leonardo Cândido Rolim. "Tempos das carnes" no Siará Grande: dinâmica social, produção e comércio de carnes secas na vila de Santa Cruz do Aracati (c.1690-c. 1802), João Pessoa, UFPB, 2012. , p. 5.

167. Idem. 
mediante o pagamento em dinheiro aos comerciantes que vinham de barco até Salvador. ${ }^{168}$

Mesmo que entre as décadas de 1780 e 1790 houvesse uma nítida preponderância do gado em pé registrado na Feira de Capuame, quando comparado com o montante passado pelos registros das capitanias do Sul, é preciso ter em mente que a virada do século XVIII para o XIX foi decisiva para as partes meridionais da América Portuguesa ultrapassarem a produção e comercialização do gado criado nos sertões baianos. O final da guerra na região platina deu impulso à produção ganadina no sul. A formação dos primeiros rebanhos contou largamente com reses roubadas das estâncias pertencentes aos espanhóis, possibilitando um rápido crescimento em curto prazo.

Faz-se necessário tecer uma comparação mais detalhada sobre a produção das duas áreas especializadas na criação de gado na virada do século XVIII e XIX. Por ora, cabe perceber que a composição média dos rebanhos em ambas as regiões diferenciavam pouco entre si neste mesmo período. Baseada na "Relação dos moradores que possuem campos e animais, 1784", localizada no Arquivo Nacional do Rio de Janeiro e em 240 inventários postmortem do Rio Grande do Sul abertos entre os anos de 1765 a 1815, a historiadora Helen Osório chegou à conclusão de que mais da metade das unidades produtivas possuíam uma média de cem cabeças de gado, enquanto que o número mais representativo e vultuoso dos rebanhos concentrava-se nas grandes e poucas fazendas formadas por mais de 2.000 bovinos. ${ }^{169}$ Possivelmente este padrão possuía uma similaridade com a realidade das fazendas de gado dos sertões baianos. Trataremos deste assunto de modo mais detalhado no segundo capítulo.

Evidente que aqui apontaremos somente as linhas gerais de comparação superficial entre as duas áreas criatórias. Primeiramente, não está sendo levado em consideração a quantidade de boiadas comercializadas em outras praças importantes das capitanias do Norte, tais como o litoral de Pernambuco e as capitanias anexas, exceto os dados referentes ao comércio de carne seca. Também aqui não aparece o cálculo das reses ou charque transportadas pelas embarcações saídas do Rio Grande do Sul em direção à praça comercial do Rio de Janeiro, que passou a demandar ainda mais alimentos após a transferência da capital da América portuguesa em 1763, mas sobretudo com a vinda da família Real em 1808.

Depois da relativa tranquilidade estabelecida nas regiões de fronteira do Rio Grande do Sul, graças à preação de centenas de reses pertencentes aos espanhóis, moradores da banda oriental e colônia de Sacramento, a capitania disparou na produtividade das estâncias destacando-se a formação de enormes rebanhos ${ }^{170}$ e a grande produção de charque baseada na mão-de-obra escrava

\footnotetext{
168. Antonio Gomes Ferrão Castelo Branco. Borrador... fl. 50.

169. Idem, p. 114 e segs.

170. Sobre as estâncias do Rio Grande do Sul, ver: Gabriel Aladren. Sem respeitar fé nem tratados: escravidão e guerra na formação histórica da fronteira sul do Brasil. (Rio Grande do Sul, c. 1777-1835). UFF, Niterói, 2012.
} 
importada exponencialmente a partir de 1807.171 A capitania também foi a grande beneficiada com a seca de 1791 que atingiu parte dos sertões pernambucanos e cearenses, passando a exportar gado e concorrer diretamente com a produção de charque das áreas de indústria mais consolidada. ${ }^{172}$ Interessante observar que para o caso dos sertões baianos, o ano de menor produção foi 1793, possivelmente reflexo da seca generalizada devido ao fenômeno do El Niño. ${ }^{173}$

O final do século XVIII também foi marcado por uma inflexão na produção de gado nas capitanias do norte. As revoluções e guerras ocorridas na Europa e o desmantelamento da produção de gêneros no Caribe e outras partes da América facilitaram o incentivo necessário para que muitos fazendeiros convertessem suas terras antes ocupadas por gado em áreas de produção de algodão e açúcar, além da necessidade de exportação forçada de mandioca para o reino de Portugal devido a uma carestia do gênero na metrópole. ${ }^{174}$

Possivelmente a virada do século XVIII para o XIX pegou de surpresa autoridades e produtores da capitania da Bahia e adjacentes. Acostumadas com o bom andamento do negócio e um volume razoável de gado enviado para uma das principais praças comerciais da América Portuguesa (apesar dos momentos pontuais de carestia causados muito mais pela ação humana do que por fatores naturais), mesmo que a tendência a longo prazo fosse o agravamento da situação, as capitanias mais ao norte passaram por um período de desarranjo. Por mais que a carestia e os problemas de abastecimento fossem sempre citados pelos moradores e autoridades da cidade de Salvador, para o período estudado, não houve um momento com falta mais crônica do que as décadas de 1780 e 1790. A Bahia estava longe de ser a capitania mais atingida com as faltas de chuva. É possível notar nas tabelas produzidas a partir das informações constantes nos "Livros de Registro de Entrada de Gado" da feira de Capuame que não houve uma queda vertiginosa no abastecimento da capital, não sendo razoável pensar portanto, em uma crise catastrófica capaz de justificar a atrofia de toda uma região. ${ }^{175}$

171. Maximiliano Menz. Entre dois Impérios: Formação do Rio Grande na Crise do Antigo Sistema Colonial (1777-1822). São Paulo, USP, 2006. p. 141.

172. Idem.

173. Mike Davis . Holocaustos Coloniais: Clima, fome e imperialismo na formação do Terceiro Mundo. Rio de Janeiro, Record, 2002; Henry Diaz e Vera Markgraf. El Niño Historical and Paleoclimatic Aspects of the Southern Oscillation. London, 1993.

174. Leonardo Cândido Rolim, op. cit.; Guillermo Palacios. Cultivadores Libres, Estado y Crisis de la Esclavitud en Brasil en la Época de la Revolución Industrial. Mexico, 1998.

175. Há um debate ainda não encerrado sobre as características da pecuária nos sertões baianos na passagem do XVIII para o XIX. Se por um lado, autores como Caio Prado Junior, pensavam em uma atrofia generalizada da região na virada do século, trabalhos monográficos demonstram os diferentes impactos não só da seca mais de uma série de fatores que mudou drasticamente os sertões baianos, no decorrer do século XIX, com a diminuição do tamanho das unidades produtivas, a perda de centralidade da pecuária para a economia regional, além da concorrência com a produção crescente de gado no Rio Grande do Sul e charque na capitania de Pernambuco, Ceará e Rio Grande do Norte. Charles Boxer é um dos pesquisadores que menciona os impactos das secas para a produção pecuarista. Em "A Idade de Ouro", o autor afirma que as periódicas secas que ocorreram no nordeste entre o século XVIII pareciam não ter sido tão devastadoras quanto nos séculos seguintes. Charles 
A virada do século XVIII para o XIX sem dúvida foi marcado por dificuldades, disputas políticas acirradas, mas não por um momento de fome generalizada como os sertões baianos presenciariam nos séculos subsequentes. Sendo assim, depois das décadas de turbulência, a pecuária de algumas partes dos sertões de algumas partes (quando a produção não foi amplamente substituída pelo cultivo de algodão) retomou fôlego, mesmo que não chegasse nem aos pés da produtividade exponencial das estâncias sulistas, marcada por um salto qualitativo, tanto nas técnicas, quanto na exploração do trabalho escravo e principalmente após todo o aprendizado acumulado pelo exemplo das regiões de ocupação mais antiga.

Mesmo sendo ultrapassada pela produção sulista, não havia possivelmente ponto de comércio e entrada de gado com movimentação equiparável no restante da colônia. A feira de Capuame mostrou-se no decorrer de todo o século XVIII como o mais importante centro de negociação do gado em pé, mesmo que o comércio não fosse tão livre assim. Marcado por uma lógica comum às sociedades de Antigo Regime, tanto nas colônias quanto nas metrópoles, prevaleceu o controle e a interferência da Câmara Municipal de Salvador sobre as diretrizes e a dinâmica de funcionamento da feira de Capuame, visando sempre à política do bem comum, garantindo que o gênero de primeira necessidade não fosse alvo de especulação e negociata por parte de ambiciosos comerciantes dispostos a desabastecer uma região inteira para garantir o bom andamento de seus negócios. Para uma realidade de livre mercado, a ganância falava mais alto.

Sendo assim, depois da institucionalização da feira de Capuame em 1727, estamos diante de uma registro de entrada de gado que eventualmente possuía um espaço de comercialização de gado, e não o contrário. Desde o primeiro momento, o estabelecimento de Capuame, enquanto ponto de arrebanhamento e posterior local de registro do gado deslocado para Salvador, tinha um caráter vinculado, acima de tudo, a necessidades fiscais e tributárias revestidas com uma preocupação de suprir a necessidade (de fato existente) quanto à composição da matalotagem das Naus e tropas, além da alimentação dos funcionários, religiosos e parte da população. $O$ desenvolvimento do comércio foi uma consequência, um desdobramento impulsionado pela aceleração da cisão entre campo/cidade, rural/urbano. A venda de gado em Capuame antes de ser vista unica e exclusivamente como manifestação da complexidade comercial da colônia em pleno desenvolvimento de suas forças produtivas, positivado pelo surgimento de um mercado interno, deve ser entendido como aprofundamento das contradições de uma sociedade cindida, em que seus habitantes encontravam-se cada vez mais distantes de autoproduzirem suas condições básicas de vida, "condenados as trocas". ${ }^{176}$

Não se tratava certamente de uma feira de gado tal como podemos imaginar, se tivermos por parâmetro as feiras do século XIX e XX, nas quais as reses eram livremente negociadas e encaminhadas sabe-se lá para onde. Ali

Boxer. op. cit., p. 208 e 211. Erivaldo Fagundes Neves. Uma comunidade sertaneja. Da sesmaria ao minifúndio: Um estudo de história regional e local. Feira de Santana, 2008.

176. Fernand Braudel. op. cit. p. 42 e segs. 
definitivamente não funcionava um espaço de livre comércio. Não era portanto, uma feira de gado que eventualmente passou a registrar o gado que por ali passava, por mais que essa seja a sua aparência à primeira vista, devido à ordem cronológica com que os fatos ocorreram. Escolhido inicialmente como ponto de arrebanhamento, tendo como permitida a atuação de marchantes - cujo papel social mudou consideravelmente, diga-se de passagem177 -, por mais que ali se estabelecesse a compra e venda da mercadoria gado antes mesmo da implementação do registro, o comércio nunca foi efetivado de modo livre e desimpedido de regras estabelecidas pela municipalidade. Tal afirmação não diz respeito apenas a regras gerais sobre o andamento do comércio (pesos e medidas, espaço específico para a negociação, proibição de atravessadores), pois como foi bem lembrado por Karl Polanyi, a própria ideia de livre mercado é uma utopia. Refiro-me à limitação do número de agentes mercantis dedicados à negociação do gado, à quantidade de gado comprado por cada um deles depois de todo um esquema de partilha estabelecido pelos funcionários régios. Ora, esta não era uma peculiaridade da América Portuguesa e muito menos da feira de Capuame. Quando falamos de Capuame, estamos nos referindo a uma feira de gado de Antigo Regime.

\subsection{Superintendência e vigilância}

Em 1727 foi criado a superintendência do registro de entrada da feira de Capuame. ${ }^{178} \mathrm{~A}$ superintendência era uma espécie de delimitação jurisdicional circunscrita a uma determinada área geográfica. Ou seja, referia-se a uma dada região sobre a qual funcionava um tipo de repartição da gestão pública vinculada à ideia de suprema administração sobre um assunto específico. Neste caso, a gestão estava relacionada à inspeção do posto de arrecadação fiscal estabelecido no sítio de Capuame, após a decisão de viabilizar o envio do cabedal necessário ao dote dos príncipes de Portugal a partir da taxação do comércio do gado em pé. ${ }^{179}$

A superintendência era um modelo administrativo já conhecido no reino de Portugal. Na América Portuguesa, a experiência mais relevante e lembrada foi a criação da Superintendência do Ouro das Minas Gerais, posta em execução a partir do regimento de 1702, mesmo ano da implementação da Superintendência do Tabaco em Bahia e Pernambuco. ${ }^{180}$

\footnotetext{
177. Esse assunto será melhor analisado na segunda parte do terceiro capítulo dedicado a pensar a atuação dos agentes mercantis envolvidos no comércio do gado. Por ora, cabe adiantar que foi possível perceber a mudança de importância e de posicionamento social dos marchantes entre o século XVII e XVIII. A hipótese inicial é a própria preponderância do comércio e da economia de mercado sobre os diversos aspectos da vida social no período setecentista.

178. DH. "Provisão da serventia do ofício da Superintendência do Registo do Gado da Capuame provido na pessoa do Capitão Luiz Pereira de Almeida ." 15 de março de 1728. Vol. 48, p. 208 .

179. Idem.

180. Gustavo Acioli Lopes. Negócio da Costa da Mina e comércio atlântico: tabaco, açúcar, ouro e tráfico de escravos, Pernambuco (1654-1760). São Paulo, USP, 2008.
} 
O superintendente, portanto, é "aquele que tem suprema autoridade na administração e execução de alguma coisa”. ${ }^{181}$ Refere-se ao ato de inspecionar, vigiar e dirigir aos que entendem em um trabalho. Era esse o mais alto cargo público nomeado para gerir e administrar as atividades efetivadas em Capuame. O superintendente era o grande responsável pela feira, cuidando exclusivamente dos assuntos vinculados ao registro de entrada e ao comércio do gado em pé naquele sítio. Precisava ser necessariamente uma figura de muita confiança tanto do governador general (com quem mantinha constante correspondência) quanto dos vereadores da Câmara Municipal de Salvador (a quem prestava contas semanalmente quanto ao valor total arrecadado). Deveria manter as autoridades sempre informadas dos problemas referentes ao comércio e passagem das boiadas pela região. Qualquer ação de atravessadores e contrabandistas precisava ser informada e coibida com a maior rapidez possível.

O primeiro superintendente nomeado para administrar o registro de entrada de gado estabelecido na feira de Capuame foi o Capitão Luiz Pereira de Almeida. Não havia um período determinado para a validade da serventia no ofício. O capitão permaneceria no cargo até que o governador ou os vereadores dissessem o contrário. ${ }^{182}$

Segundo o que faz crer a provisão do superintendente de Capuame, o Capitão Luiz Pereira de Almeida já exercia um ofício vinculado à vigilância e ao controle do encaminhamento das boiadas da região de Capuame para a cidade de Salvador antes de ser estabelecido o registro de entrada de gado. Trocava cartas com o governador-geral desde pelo menos 1724, momento em que fora nomeado capitão da Companhia de Infantaria da Ordenança do regimento do coronel Garcia D'Avila Pereira:

\footnotetext{
"que compreende desde o extremo da companhia do capitão Marcos de Araujo Aranha até a boca da Mata de São João, sempre pela estrada do sertão da parte do mar que criei de novo em virtude da minha Provisão de vinte de julho do ano de mil setecentos e dezoito por que ordenei àquele governo geral fizesse alistar toda a gente que havia naquela cidade e seu recôncavo capaz de tomar armas e a distribuísse em regimentos e companhias." 183
}

Infelizmente até o momento só foram localizadas as cartas escritas pelo governador tendo o capitão como destinatário e não o contrário. Nelas há sempre a menção do envio semanal de um rol, uma espécie de relatório, em que o capitão Luiz Pereira de Almeida discriminava a quantidade de cabeças de

\footnotetext{
181. Raphael Bluteau. Vocabulario Portuguez \& Latino, aulico, anatomico .... Coimbra, 1728, vol. 7 , p. 788. disponível em : < http://www.brasiliana.usp.br/dicionario/edicao/1.

182. DH. "Provisão da serventia do ofício da Superintendência do Registo do Gado da Capuame provido na pessoa do Capitão Luiz Pereira de Almeida .” 15 de março de 1728. Vol. 48, p. 208 .

183. DH. Cartas, patentes e provisões (1724-1728). "Luiz Pereira de Almeida no posto de capitão da Companhia de Infantaria da Ordenança, à folha 199 verso" . Vol 73, p. 309; DH. "Patente de confirmação por S. M., que Deus Guarde, concedida ao Capitão Luiz Pereira de Almeida" 26 de março de 1725 . vol. 74 , p. 84.
} 
gado que saía de Capuame em direção a Salvador. ${ }^{184}$ Dados de suma relevância para um levantamento do comércio de gado na feira de Capuame nesse primeiro momento de sua institucionalização, mas que não estavam depositados nos fundos documentais dos arquivos brasileiros nos quais restam manuscritos do período colonial.

$\mathrm{Na}$ medida em que foi estabelecido a obrigatoriedade de todo o gado encaminhado à cidade de Salvador passar pelo registro de entrada da feira de Capuame para garantir uma maior arrecadação do imposto, ao superintendente competia então assegurar uma coleta eficiente dos donativos, assim como prestar assistência nos assuntos condizentes ao abastecimento da capital da colônia, enviando o máximo de bovinos possível através dos marchantes. Os marchantes eram os comerciantes de gado que precisavam de licença municipal para poder atuar. Conforme foi proibido o comércio e a passagem dos bovinos por outro lugar que não fosse Capuame, evidentemente os marchantes também passaram a ser impedidos de efetivar o comércio em outro local que não fosse a feira.

Ao superintendente cabia também cuidar para que não houvesse descaminho das boiadas. Era comum que parte do gado fosse enviado para os engenhos do Recôncavo sem autorização do governador. Sabendo da grande necessidade que as unidades produtivas do Recôncavo Baiano tinham do gado de corte e do boi manso para manterem suas lavouras e fábricas funcionando, era de praxe que o governador autorizasse fazendeiros a levar animais diretamente dos sertões para o Recôncavo sem o pagamento do imposto em Capuame. ${ }^{185}$ Para que a isenção ocorresse, era necessário que durante aquela semana houvesse uma quantidade de gado sobejo, ou seja, uma quantidade de gado superior ao estabelecido para ser encaminhado aos currais e açougues de Salvador. Por exemplo, o número satisfatório de bovinos para abastecer a cidade semanalmente era de duzentas e cinquenta reses. ${ }^{186}$ Aquilo que ultrapassasse este montante era considerado gado sobejo e podia ser conduzido sem problemas para as unidades produtivas do Recôncavo. Entretanto, havia um outro detalhe: as cabeças de gado enviadas para o Recôncavo não poderiam ser de uma quantidade tal que as autoridades presumissem que fossem passadas para serem revendidas. ${ }^{187}$

Outro dado importante sobre a isenção e a licença emitida pelo governador general para encaminharem gados sertanejos diretamente para o Recôncavo era que a maior parte dos pedidos deferidos eram feitos por fazendeiros que possuíam simultaneamente currais em algum lugar do sertão e unidades produtivas no Recôncavo Baiano. Dentre eles estavam os membros da família Rocha Pitta (os irmãos Antonio, Cristovão e Thomé Lançarote),

184. DH. “Para o Capitão Luiz Pereira de Almeida" 14 de agosto de 1724, vol. 71, p. 304 ; "Carta para o Capitão Luiz Pereira de Almeida” 21 de agosto de 1724. vol 71, p. 307; "Carta para o Capitão Luiz Pereira de Almeida " 9 de setembro de 1724. vol. 71 p. 321, entre outros.

185. AMS. Ofícios do governo (1712-1737).

186. DH. "Carta para o Capitão Luiz Pereira de Almeida” 14 de janeiro de 1726. vol 72, p. 264.

187. DH. "Para o Capitão Luiz Pereira de Almeida" 14 de agosto de 1724, vol. 71, p. 304 
Antônio Gomes Ferrão Castelo Branco, o Mestre de Campo da Casa da Torre e a família Argollo. ${ }^{188}$

As diretrizes sobre o comércio de gado mudavam com uma relativa frequência, de acordo com a experiência e necessidade dos agentes envolvidos nas transações comerciais. Por muito tempo, a venda de gado nas estradas era terminantemente proibida, na medida em que muitos atravessadores compravam os bovinos pelos caminhos e acabavam por não encaminhá-los para a feira e posteriormente para os açougues públicos. Todas as reses deveriam ser obrigatoriamente enviadas à Capuame, assim como todos os interessados em comprar os "bixanos" deveriam fazer negócio somente naquele espaço. ${ }^{189}$ No sentido de inibir a prática ilegal de compra de boiadas fora da feira, passou a ser competência dos coronéis e demais oficiais dos regimentos de infantaria de cada distrito cuidar para que tal delito não ocorresse em sua jurisdição. Em caso de desobediência e de fazerem vista grossa ao contrabando, deveriam ser remetidos presos até a cadeia da cidade e levados à presença do governador-geral. Foi o que ocorreu com os capitães José Borges e Antonio de Araújo em $1725^{190}$ e com o Capitão João Borges David em $1726 .{ }^{191}$

Enquanto prevaleceu esta diretriz, o superintendente precisava ficar atento e enviar soldados e ordens a outros militares pedindo para averiguar se o gado que chegava até Capuame vinha das fazendas sertanejas dos senhores de engenho e demais produtores ou se os condutores compravam o gado dos criadores existentes nos caminhos. ${ }^{192} \mathrm{O}$ intuito desta medida era impedir que os bovinos chegassem com um preço exorbitante na feira depois de comercializado por passadores, atravessadores e outros intermediários. ${ }^{193}$ Esta mesma proibição visava também dificultar o contrabando e impedir que as reses vendidas pelo caminho fossem direcionadas para outros pontos que não a feira de gado em Capuame. Com o tempo, tal medida se tornou impraticável, visto ser mais interessante, até mesmo para os criadores, nem sempre levar por sua própria conta o gado para Capuame. O mais importante, do ponto de vista da arrecadação e fiscalidade, era impedir que o gado deixasse de passar pelo registro. Todavia, era tarefa da municipalidade garantir um abastecimento eficiente com produto de qualidade e com um preço justo, mesmo que isso

188. AMS. "Livros de Registro de Entrada de Gado" da Feira de Capuame (1784-1789)

189. DH. "Portaria para o Escrivão da Câmara da vila de São João de Água-Fria." 16 de junho de 1734. vol. 75, p. 316; DH. "Carta para o Coronel Domingos Borges de Barros" 11 de maio de 1726 , vol. 72 , p. 324.

190. DH. "Carta para o Capitão Luiz Pereira de Almeida." 9 de abril de 1725. vol. 72, p. 92.

191. DH. "Carta para o Coronel Domingos Borges de Barros" 11 de maio de 1726 , vol 72, p. 324.

192. DH. "Para o Capitão Luiz Pereira de Almeida" 13 de outubro de 1724, vol. 71, p. 335.

193. Segundo Fernand Braudel, a venda (ou melhor, a revenda) de produtos pelos caminhos era considerado crime na Europa. A prática de comerciantes irem ao encontro dos produtores para comprar as mercadorias antes delas chegarem às feiras era considerado fraude grave. Mesmo assim a prática era comum em todas as cidades, desde Londres à Paris. Fernand Braudel, op. cit, p. 34; No caso da América Portuguesa, Flávio Marcus Silva observa a mesma política no abastecimento das Minas Gerais. "Nas Minas setecentistas, qualquer pessoa que comprasse mantimentos e os revendesse fora das regiões onde, pela lei, deviam ser comercializados, sem que para isso tivesse licença das autoridades, era considerada um atravessador." Flávio Marcus Silva, op. cit. , p. 98. 
nem sempre acontecesse, segundo as constantes reclamações da população. A solução foi a criação de outros registros de entrada de gado pelo caminho, como já citado anteriormente.

Dos registros estabelecidos entre o último decênio do século XVIII e o início do seguinte, de certo os mais importantes e movimentados eram os de Cajueiro, Saco de Moura e Santana dos Olhos D'Água. Este último registro, localizado na freguesia de São José de Itapororocas ficava próximo a fazenda de Santana dos Olhos D'Água, conhecido ponto de entroncamento de várias estradas e excelente ponto de contrabando. A criação do registro ali, entre 1800 e 1801, tinha o objetivo óbvio de impedir o descaminho e comércio irregular de gado na região. Todavia, as encruzilhadas da Fazenda de Santana Olhos D'Água ganharam tanta importância no princípio do século XIX que na década de 1830, a feira de Capuame foi transferida para lá: Feira de Santana. ${ }^{194}$

As cartas escritas pelo governador ao Capitão Luiz Pereira de Almeida dão a entender que o superintendente enviava notícias, tais como o nome e a região em que moravam os contrabandistas atuantes nos arredores da feira, repassando ordens de prisão entregues aos coronéis e capitães dos regimentos que respondiam pelas regiões nas quais circulavam os infratores. ${ }^{195}$ Esse tipo de ordem foi expedida com certa frequência, como por exemplo no pedido de prisão do atravessador Francisco Rodrigues. ${ }^{196}$ O Coronel Manuel de Brito Casado foi um dos responsáveis pela prisão de Miguel Rodrigues, "homem que vive de atravessar gado pela beira do Itapicuru e Tucano"197

Ao que tudo indica, o capitão Luiz Pereira de Almeida residia nas proximidades da feira e por lá permanecia na maior parte do tempo. Quem encaminhava pessoalmente ao governador-geral o rol contendo a quantidade de gado registrado e a correspondência referente à Capuame era um dos marchantes. Estes, por sua vez, não pestanejavam em fazer chegar aos ouvidos do governador queixas quanto às ações e negligências supostamente cometidas pelo capitão. Muitos deles diziam que o capitão Luiz Pereira de Almeida não se dava nem ao trabalho de sair de sua casa, deixando os cuidados com o sítio de Capuame ao "Deus dará". ${ }^{198}$ Outros diziam haver erros no número de reses que apareciam nos róis entregues ao governador. Tais denúncias geraram a criação de uma nova norma: a obrigatoriedade de todos os documentos serem acompanhados com a assinatura do capitão e dos marchantes envolvidos para não haver desculpas de erro na contabilidade por ambas as partes. Mesmo diante das acusações, o governador parecia acreditar mais no capitão, demonstrando confiança e evidenciando que tais queixas não passavam de conversa sem fundamento por parte dos marchantes, como demonstra em carta de 9 de setembro de 1724:

\footnotetext{
194. Rodrigo Freitas Lopes. Nos currais do matadouro público: o abastecimento de carne verde em Salvador no século XIX. (18 30-1873), Salvador, UFBA, 2009, p. 37

195. DH. "Carta para o Capitão Luiz Pereira de Almeida." 21 de agosto de 1724. vol. 71, p.312

196. DH. "Carta para o Capitão Luiz de Almeida." 31 de agosto de 1725. vol. 72, p. 163.

197. DH. "Carta que se escreveu ao Coronel Manuel de Brito Casado" 10 de dezembro de 1725. vol.

72 , p. 242.

198. DH. "Para o Capitão Luiz Pereira de Almeida" 13 de outubro de 1724, vol. 71, p. 335.
} 
"importam pouco as arguições dos marchantes ou seus parciais, porque nenhumas bastarão sem uma exata informação para me fazer formar diferente conceito, em cujos termos o que importa é executar as minhas ordens e que venha muito gado para sustento do povo, e como no que até agora tem obrado tem procedido muito à minha satisfação e às ordens que tem distribuído se devem executar, se me não oferece de novo que dizer-lhe." 199

As rivalidades entre os marchantes e o capitão Luis Pereira de Almeida, mesmo antes da institucionalização da feira, parecem ter tomado proporções ainda maiores devido à interferência do futuro superintendente nos negócios de compra e venda do gado, fazendo com que em 15 de dezembro de 1724, depois de uma enxurrada de reclamações envidas ao governador, a autoridade decidisse suspender o bando (uma espécie de decreto afixado nos lugares públicos) que proibia a compra de gado pelos marchantes fora de Capuame. A ordem foi suspendida no sentido de permitir que os marchantes fossem negociar as boiadas diretamente com os criadores em qualquer parte dos caminhos e sertões mais próximos, contanto que as boiadas fossem encaminhadas diretamente e integralmente para Capuame e tivessem por destino final sucessivamente o curral do conselho e um dos açougues públicos de Salvador. ${ }^{200}$ A proibição/permissão do comércio do gado pelas estradas oscilou muito durante o funcionamento da feira de gado. As diretrizes tendiam a mudar constantemente conforme as disputas de interesses eram colocadas em debate motivados pelos conflitos existentes entre as partes envolvidas com o comércio e a fiscalização do gado em pé.

Mas as acusações por parte dos marchantes em relação à autoridade máxima da feira não pararam e a confiança aparentemente inabalável do governador parece entrar em uma fase de declínio. Através das denúncias feitas pelos frequentadores de Capuame, o governador ficou sabendo da quantidade a mais de gado que o superintendente permitiu que as pessoas de status levassem para seus engenhos no Recôncavo Baiano sem autorização prévia, além da informação de que um dos filhos do capitão passou a se envolver com as negociações do gado, abalando a imparcialidade e o desinteresse no cargo. ${ }^{201} \mathrm{~A}$ fartura e o contentamento com o abastecimento da cidade e principalmente com a abundância de gado enviado para as Naus das Índias e demais embarcações das frotas estacionadas nos meses seguintes, fizeram com que o governador possivelmente esquecesse as denúncias e elogiasse abertamente o capitão Luis Pereira de Almeida. ${ }^{202}$ Tanto foi assim que todos os episódios acima relatados ocorreram antes da nomeação do capitão para o cargo de superintendente, demonstrando mais uma vez a confiança do governador mesmo em meio a tantas acusações.

199. DH. "Carta para o Capitão Luiz Pereira de Almeida" 9 de setembro de 1724, vol. 71, p. 321.

200. DH. "Carta que se escreveu ao Capitão Luiz Pereira de Almeida" 15 de dezembro de 1724. vol. 72. p. 6.

201. DH. “Carta para o Capitão Luiz Pereira de Almeida." 9 de abril de 1725. vol. 72, p. 92

202. DH. "Para o Capitão Luiz Pereira de Almeida" 12 de maio de 1725. , vol. 72, p. 117; "Carta para o Capitão Luiz Pereira de Almeida" 4 de junho de 1725. vol. 72, p. 125. 
A estima do Conde de Sabugosa com relação ao superintendente era diretamente proporcional à bonança e fartura na hora da abastecer de carne verde a cidade. $\mathrm{O}$ contentamento da autoridade oscilava tanto quanto o total arrecadado pelos donativos e impostos cobrados na feira de Capuame.

Em 1732, a situação começou a ficar trágica para o lado do capitão Luiz Pereira de Almeida. O valor enviado pelo tesoureiro do donativo à Câmara Municipal de Salvador foi de "trezentos e tantos mil réis". O governador-geral tinha certeza que o total arrecadado era muito superior ao montante declarado, fazendo com que intimasse o superintendente a enviar o restante do valor em até quinze dias e o alertando sobre os riscos de "deixar parado dinheiro na mão", além dos problemas que a cobrança não-imediata em "dinheiro de contado" e o estabelecimento de créditos e dívidas em relação à cobrança do imposto poderia acarretar para a arrecadação do donativo. ${ }^{203}$

A partir deste episódio, a prática [ou o hábito, etc.] do superintendente de deixar passar na frente as boiadas pertencentes às figuras da elite baiana ou pessoas de alguma influência e prestígio social (sem a prévia aprovação da autoridade máxima da capitania) passou a ser extremamente mal vista pelo governador que não mais tolerou tais atitudes. O capitão Luis Pereira de Almeida foi repreendido severamente na ocasião em que permitiu aos padres da Companhia de Jesus passarem dois lotes de boiadas (possivelmente vindas das fazendas de gado do Piauí) sem declarar no registro de entrada. O governador fez referência à idade avançada do capitão e o ameaçou declarando que "se estes [muitos anos] o impossibilitam para não satisfazer a sua obrigação, nomearei pessoa que o substitua e execute as minhas ordens."204

Finalmente, em outubro de 1734, o governador emitiu uma portaria ao superintendente acusando-o de faltar com suas obrigações e com a observância necessária ao ofício para o qual fora nomeado. Segundo as diretrizes da Câmara Municipal de Salvador, só poderia ser enviado para as vilas do Recôncavo o gado manso e sobejo, ou seja, o gado direcionado a servir de força motriz nas lavouras e engenhos ou as reses que passassem do número estipulado para serem encaminhadas à Salvador. O capitão Luiz Pereira de Almeida fora acusado na ocasião de permitir que o Padre Matias de Albuquerque e o Capitão Antônio da Cunha levassem gado sem autorização do governador e sem passar pelo registro de entrada de gado da Feira de Capuame, não cobrando o imposto e não anotando no livro dedicado a documentar as ocorrências. ${ }^{205}$

Depois de tantas acusações e por decisão do governador-geral, em 5 de novembro de 1734, o Capitão Luiz Pereira de Almeida deixou o cargo de superintendente que passou a ser ocupado por Antonio Gonçalves Guimarães. Responsável pela administração do registro de entrada de gado na Feira de Capuame, o novo superintendente receberia de vencimento o mesmo valor de trezentos mil réis por ano pago ao seu antecessor dez anos atrás, assumindo

203. DH. "Portaria para o Capitão Luiz Pereira de Almeida" 18 de novembro de 1732. vol. 75, p. 112.

204. DH. "Portaria para o Capitão Luiz Pereira de Almeida" 18 de novembro de 1732. vol. 75, p. 112.

205. DH. "Portaria para o Capitão Luiz Pereira de Almeida" 11 de outubro de 1734. Vol. 76, p. 13. 
todas as responsabilidades deixadas. ${ }^{206}$ Não foi encontrada nenhuma referência sobre Antonio Gonçalves Guimarães. É ignorado se possuía patente e qual o cargo que ocupava antes da nomeação.

Depois da experiência de Capitão Luiz Pereira de Almeida por quase dez anos no cargo de superintendente da feira de Capuame foi possível mapear sucessivamente a passagem do ofício para outros funcionários. Depois dos quatro anos de ofício exercido por Antonio Gonçalves Guimarães, Caetano de Araújo $\mathrm{Lasso}^{207}$ (heterônimo de um poeta bucólico lisboeta) ${ }^{208}$ foi nomeado para o cargo de confiança. Permaneceu no ofício somente três anos e foi sucedido pelo capitão Inácio Gomes de Sousa, ocupante do posto entre os anos de 1741 a 1753.209

Para a segunda metade do século XVIII foi mais complicado continuar o arrolamento dos nomes dos ocupantes do cargo de superintendente da feira de Capuame. Sabe-se que em 1753, Francisco Xavier de Faria constava como a autoridade que mantinha correspondência privada com o sargento-mor e senhor de engenho Antonio Gomes Ferrão Castelo Branco, herdeiro do morgado do Porto da Folha, referente ao encaminhamento de gado em pé vindo de suas fazendas sertanejas para alimentar seus familiares e escravos, além dos bois mansos para serviço de fábrica. ${ }^{210}$

Para a passagem do século XVIII para o século XIX, merece destaque a atuação do tenente Manoel Henriques de Carvalho. Sua presença na feira de Capuame como funcionário é documentada a partir de 1784, tanto nas cartas enviadas pelo governador quanto pelos "Livros de Registro de Entrada de Gado". ${ }^{211}$ Mesmo não ficando evidente se ocupava o cargo de superintendente, em muitas ocasiões foi tratado como uma espécie de

206. APEB. Tribunal da Relação. Provisões e serventia de ofícios (1733-1735). Seção de Arquivo Colonial e Provincial. n. 511. fl. 254 f-v.

207. AHU. AHU_CU_005, Cx. 62, D. 5267.[ant.1738, Julho, 17] "Requerimento de Caetano de Araújo Lasso ao rei [D. João V] solicitando provisão para servir no ofício de Superintendente da Feira da Capuame". Anexo: certidão. Documentos Avulsos. Capitania da Bahia. Projeto Resgate .

208. Não foi possível saber se eram a mesma pessoa. O poeta Caetano de Araujo Lasso publicou duas éclogas em 1759; uma pela Oficina de Francisco Luis Ameno e outro pela Oficina de Manuel Antonio Monteiro. Innocencio Francisco da Silva. Diccionário Bibliographico Portuguez aplicados a Portugal e ao Brasil, Lisboa, 1859, Segundo Tomo, p. 6.

209. AHU_CU_005, Cx. 71, D. 6020 [ant. 1741, Dezembro, 4] "Requerimento de Inácio Gomes de Sousa ao rei [D. João V] solicitando ordem para que se lhe dê posse no cargo de superintendente da feira da Capuame, na cidade da Bahia, e que o procurador do Conselho pague da sua bolsa o ordenado que o suplicante deveria vencer no tempo que foi impedido." Documentos Avulsos. Capitania da Bahia. Projeto Resgate; AHU_CU_005, Cx. 116, D. 9050. [ant. 1753, Outubro, 5, Bahia] "Requerimento de Inácio Gomes de Sousa, ao rei [D. José] a pedir certidão de que foi provido na Superintendência do donativo dos Gados.” Documentos Avulsos Capitania da Bahia. Projeto Resgate.

210. Antonio Gomes Ferrão Castelo Branco. Borrador em que lanço todas as cartas que escrevo, principiado em agosto de 1742, estando na Babia. São Paulo, Coleção Mindlin. Transcrito por Rosana Gonçalves sob orientação da Profa Dra Mary Del Priore e gentilmente cedido pelo Prof. Dr. Istvan Jancsó, fl. 25.

211. APEB. Senado da Camara de Salvador. Correspondência expedida para o governo (1789). Maço 485-1. Portaria de 2 de julho de 1789. fl. 25; APEB. Carta do governo para várias autoridades (17871802). Maço 159. Carta para Desembargador Antonio Feliciano da Silva Carneiro. 18 de março de 1793; APEB. Correspondência recebida pelo governo. Senado da Camara da Bahia (1783-1799). Maço 201-14. 15 de março de 1792. 
autoridade máxima sobre os assuntos referentes à Capuame, assumindo a dianteira do registro interinamente. São várias as referências dos encaminhamentos de gado diretamente realizado por Manoel Henriques de Carvalho, certamente destinado a alguma diligência especial não mencionada nos "Livros". Em algumas semanas o tenente recebia uma rês para a sua matalotagem e a de seus soldados. Possivelmente, era uma referência direta ao boi que seria abatido na feira para alimentar todos os militares que estavam de ronda e faziam a segurança da feira. ${ }^{212}$ Era Manuel Henriques Carvalho o responsável por levar todo o valor arrecadado na feira de gado de Capuame todas as semanas até os cofres públicos da Câmara. Na representação escrita por moradores da cidade de Salvador endereçada aos vereadores, Manoel Henriques Carvalho foi apontado como sendo o administrador da feira de Capuame, ou seja, ocupava em 1797 o cargo semelhante ao de superintendente mesmo que sua atuação não fosse vista com bons olhos por alguns de seus contemporâneos. ${ }^{213}$

$\mathrm{Na}$ acusação feita contra o superintendente Antonio Xavier de Brito, em 1806, a respeito da tentativa de assassinato de André Corcino da Silva, Manoel Henriques de Carvalho aparecia como possuidor da patente de sargento-mor e era apontado como alguém que servia na feira de Capuame nos momentos de impedimento do superintendente responsável pelo local. ${ }^{214}$ Tudo indica que começou a atuar na freguesia de Mata de São João ainda muito jovem, crescendo na hierarquia militar, chegando a responder interinamente pela superintendência da feira de Capuame, ostentando a patente de tenentecoronel no momento de elaboração de seu testamento, em 1828. ${ }^{215}$ É razoável pensar que, como homem de armas, Manoel Henriques de Carvalho tivesse atuado de algum modo na Guerra de Independência do Brasil, sob o comando do general Labatut no momento do cerco à cidade de Salvador e principalmente quando parte considerável das tropas estavam estacionadas em Capuame, devido sua localização estratégica. ${ }^{216}$

Assim como foi mencionado anteriormente, era comum que os superintendentes tivessem patente militar. O primeiro ocupante do cargo, Luis Pereira de Almeida, já era capitão nos arredores da Mata de São João mesmo antes de ser nomeado para a função de superintendente do registro de entrada de gado da Feira de Capuame. Participava do regimento do coronel Garcia D'Avila Pereira desde pelo menos 1724 e já possuía um papel importante na vigilância da região.

212. AMS. "Livro de Registro de Entrada de Gado (1784-1789). fl. 158.

213. APEB. Maço 201-14. Correspondência recebida pelo governo. Senado da Camara da Bahia (17831799). 8 de fevereiro de 1797.

214. APEB. Câmara para o Governador, 12 de março de 1806, maço 209-1, doc

215. Segundo o testamento de 1828, possuía o escravo José Henriques de Cavalho, natural da Costa da Mina. Depois de conquistar a liberdade concedida pelo ex-dono, o preto forro foi padrinho de vários dos escravos de Manoel Henriques Carvalho. Ver: APEB, LRT, n⿳ 19, fls. 244v-250 (11/12/1828). "Maria Ines Cortes de Oliveira. Viver e morre no meio dos seus. Nações e comunidades africanas na Bahia do século XIX.” Revista USP, São Paulo (28): 174-193, dez fev 95/96. p. 186.

216. Richard Graham. Alimentar a cidade: das vendedoras de rua à reforma liberal (Salvador, 1780-1860). São Paulo, 2013. p.225. 
Vale lembrar que o coronel Garcia D'Avila e seus parentes foram por muitos anos os responsáveis pela vigilância militar dos termos e sítios da região interiorana à Torre de Tatuapara, incluindo a feira de Capuame, ${ }^{217}$ sendo apontado pelo memorialista Pedro Calmon como o grande fundador da primeira feira colonial .218 O problema desta afirmação não é a sua plausibilidade em si, mas a conotação (com que tal ideia foi propagada até nossos dias graças ao esforço de memorialistas baianos) de engajamento estritamente privado do grande sertanista. Sem dúvida, os primeiros Dias D'Avila tiveram papel importante no estabelecimento de Capuame enquanto ponto de arrebanhamento e primitivo comércio por alguns motivos. O primeiro está vinculado ao domínio que possuíam sobre aquela região desde fins do século XVI, como bem lembrou Fernão Cardim no relato sobre sua visita às aldeias dos jesuítas localizadas na região. ${ }^{219} \mathrm{O}$ segundo é que estamos falando de um dos maiores potentados produtores de gado da história colonial. Suas fazendas e sesmarias espalharam-se pelos sertões atingindo até mesmo o sul do Piauí. Certamente possuíam interesse em fazer com que o gado escoasse para as regiões consumidoras, facilitando a abertura de estradas e o acesso dos sertões ao litoral. ${ }^{220} \mathrm{O}$ terceiro motivo é o de que a família teve um papel importante na guerra contra os holandeses ${ }^{221}$, além de estarem dentre os possíveis responsáveis pelo abastecimento de tropas que passavam pela região, mantendo guardado alimentos na casa fortificada. Sendo assim, é de se supor que os membros da Casa da Torre tiveram papel fundamental para o funcionamento de Capuame enquanto espaço de arrebanhamento. Não como grandes fundadores da primeira feira de gado, cuja memória deve ser resguardada no ilustríssimo papel de benfeitores da primitiva nação, como queria Pedro Calmon, 222 mas sim como homens cujos interesses como proprietários/sesmeiros imbricados com o papel de funcionários régios promoveram de fato a dinamização de alguns pontos auxiliadores do fluxo de mercadorias em um momento de montagem do sistema colonial.

As boiadas vindas dos sertões baianos possuíam um número médio de duzentas cabeças de gado cada. Possivelmente eram conduzidas por cerca de sete a dez homens (entre livres e escravos) devidamente armados.223 Os

217. DH. "Carta para o Coronel Garcia de Ávila Pereira com a ordem abaixo registada sobre a Companhia que exprime. " 25 de fevereiro de 1723. vol. 45, p. 54.

218. Percorrendo as notas de roda pé e referências sobre tal informação, chegamos a Pedro Calmon que por sua vez não menciona a fonte da qual retirou tal informação. O ocultamento do local em que as informações foram encontradas era comum entre os escritores do início do século XX. Pedro Calmon. História da casa da Torre, uma dinastia de pioneiros. Rio de Janeiro, 1939.

219. Fernão Cardim. Tratados da terra e gente do Brasil. Rio de Janeiro, 1925, p. 397.

220. Sobre a abertura da Estrada até Jaguaripe, ver: AMS. Atas da Camara (1718-1731). Volume 8. "Ata do dia 1 de outubro de 1718", p. 8.

221. Angelo Emílio Pessoa. As ruínas da tradição: a casa da Torre de Garcia D'Avila - família e propriedade no nordeste colonial, USP, São Paulo, 2003, p. 71.

222. Pedro Calmon, op. cit.

223. Esta estimativa baseia-se na documentação produzida pela Inspeção das Fazendas da Administração Real localizadas na capitania do Piauí. As fazendas foram confiscadas dos jesuítas no momento em que foram expulsos das possessões portuguesas. Eles tinham recebido as propriedades 
condutores, passadores e tangedores deviam impedir que o gado saísse da estrada ou se destacasse dos demais "bixanos". Manter o rebanho unido era um desafio requeredor de atenção e vigilância constante sobre as reses. Mas, por enquanto, o importante de fato é lembrar que o valor médio de uma cabeça de gado para meados do século XVIII era de $5 \$ 000$. Se pensarmos em um rebanho contendo duzentas reses, estamos diante de um montante de 1:000\$000 (um conto de réis) ambulante, quantia avultada para a época.

Evidente que os assaltos pelas estradas ocorriam com uma frequência muito maior daquela desejada pelos proprietários, funcionários das fazendas, comerciantes e autoridades régias. Vários são os casos documentados de quadrilhas atuantes nos caminhos. ${ }^{24}$ Mas não era somente a possibilidade de assaltos nas estradas e encruzilhadas o fator capaz de manter alerta os homens envolvidos diretamente com o comércio de gado. A autoridade régia, personificada na figura de oficiais e soldados das companhias espalhadas pelos sertões baianos, tinha que concentrar esforços no impedimento do contrabando e descaminhos efetivados muitas vezes por comerciantes e marchantes soteropolitanos.

Era considerado descaminho ou contrabando de gado o ato de desviar as boiadas para outros centros consumidores que não fosse a cidade de Salvador, deixar de passar pelo registro de entrada e, portanto, não efetuar o pagamento do donativo real em Capuame após o momento de institucionalização da feira no ano de 1728. Para evita-lo, era preciso assegurar que o abastecimento ocorresse de acordo com o ideal estabelecido. Isso nem sempre era possível. E portanto, a necessidade de vigilância e cuidado nos caminhos e em Capuame era uma das preocupações capazes de ocupar as autoridades régias com seguidas ordens aos militares atuantes nos arredores do trajeto percorrido pelas boiadas sertanejas.

Depois de uma denúncia de contrabando executado por marchantes que compravam gado no "sítio da Capuame" - antes da institucionalização da feira - e depois repartiam os bois para distintos "arrebaldes" da cidade, o governador ordenou ao ajudante Francisco Luiz que fosse até Capuame, acompanhado por quatro sargentos de infantaria, mais alguns sargentos do Terço dos Henrique Dias e seus soldados. Deveriam arrebanhar todas as reses que encontrassem em Capuame e pelos caminhos. Depois de remeter presos os contrabandistas, as boiadas seriam encaminhadas para o açougue público de Salvador acompanhadas pelos criadores "e negros que as costumam conduzir e pastorar". ${ }^{225}$ Durante a diligência, o ajudante receberia cinco tostões ( $\$ 400$ ) por dia, os sargentos da Infantaria a pataca $(\$ 320)$, os sargentos do terço de

como herança de Domingos Afonso Sertão. AHU. Piauí, caixa 7. "Consulta ao Sr. Martinho de Mello e Castro a respeito do que fazer com as boiadas das Fazendas dos Jesuítas" 7 de janeiro de 1790.

224. Esse assunto será abordado com mais detalhes e análise de casos concretos no segundo capítulo.

225. DH. "Portaria que levou o ajudante Francisco Luiz para a diligência a que foi da prisão dos marchantes e condução dos gados." 8 de outubro de 1718. vol. 55, p. 114. 
Henrique Dias, doze vinténs (\$240) e os soldados do terço dos homens pretos, meia pataca $(\$ 160) .226$

Em carta de 11 de outubro de 1718, endereçada novamente ao ajudante Francisco Luiz, o governador agradeceu a atuação do destinatário no encaminhamento das boiadas (visto a cidade já estar passando por um momento de carestia considerável de carne) e principalmente pelo papel que exerceu durante a prisão, em Capuame, dos marchantes acusados de desvio e contrabando. Pediu para o ajudante se recolher, terminando ali a sua tarefa, e deixar que os oficiais e soldados de Henrique Dias continuassem o trabalho de conduzir as reses que se encontravam "incontinenti". 227

Depois de institucionalizada, a feira de Capuame contou sempre com uma quantidade significativa de homens armados dispostos a garantir a continuação de sua finalidade comercial e tributária. Fora o superintendente, muitas vezes possuidor de patente tal como a de capitão do regimento da Torre, sabe-se que nas primeiras décadas de funcionamento da feira de gado, a vigilância era feita pelos homens pretos do terço dos Henrique Dias. Não sabemos muitos detalhes da atuação destes homens; segundo as Instruções da Feira de Capuame um sargento e quatro soldados do terço dos Henrique Dias passaram a assistir oficialmente naquela feira logo no momento de institucionalização, mesmo já sendo constantemente recrutados para diligências específicas desde no mínimo uma década. ${ }^{228}$ Passariam a receber o soldo do mesmo modo e na mesma quantia que os soldados atuantes na feira antes da chegada dos membros do Terço. Deveriam fazer assento ao escrivão do dia em que chegaram na feira, significando a possibilidade de não serem naturais daquele local. Interessante observar que o contrato firmado em 1731 estipulava que os soldados pretos do terço dos Henrique Dias receberiam a mesma quantidade de pagamento que os soldados anteriores, visto ser comum em muitas operações o pagamento de uma quantidade menor para os oficiais e soldados do antigo terço. 229

Sabe-se, através do relato de 1759 produzido por José Antonio Caldas, que o terço dos Henrique Dias na Bahia contava com doze companhias compostas por um capitão-mor, sargento-mor, dois ajudantes do número, dois ajudantes supra[numerários], doze capitães, doze alferes, doze sargentos do número, doze sargentos supra[numerários], doze tambores e trezentos e trinta e um soldados, totalizando 397 homens armados. 230 Tanto em Pernambuco como na Bahia não era costume nomear pretos não-naturais da terra para postos de oficiais. A exceção eram os pretos "Angola", gerando conflitos

226. Convertendo tudo em réis: uma pataca era igual a 320 réis, um vintém valia 20 réis e um tostão era 80 réis.

227. DH. "(Carta para o ajudante Francisco Luiz)" 11 de outubro de 1718. vol. 43, p. 146.

228. BN. Catálogo 68. 130A: Registro das cartas que expediram para a Cidade, vilas, capitanias e sertão (1726-1728). "Instrução que há de observar o capitão Luiz Pereira de Almeida a quem tenho encarregado a remessa do gado da feira da Capuame para esta cidade.” 7 de julho de 1727.

229. APEB. Maço 151. Carta do Governo (à várias autoridades) 1730-1734. Carta do Capitão Luis Pereira, 16 de abril de 1731.

230. José Antonio Caldas, op. cit. p.225. 
internos especialmente com libertos de origem "mina", vistos pelos oficiais do terço como "infectos" e "inimigos capitais dos brancos". 231

Não se sabe o nome e a origem dos soldados destacados para vigiar a feira de Capuame a partir de 1727. Não é possível verificar também como ficava a questão das hierarquias nos momentos de envio de ordens aos soldados atuantes na feira, mas podemos supor que respondiam diretamente ao superintendente, o capitão Luiz Pereira de Almeida, mesmo sendo da companhia de outro regimento, posto ser apontado como o responsável pelo pagamento dos soldados enquanto trabalhou no registro de entrada de gado, além de ser a autoridade máxima do local. ${ }^{232}$ Mas ao que tudo indica, os homens pretos do terço de Henrique Dias não serviram por muito tempo na feira de Capuame. Possivelmente, o Capitão Luiz Pereira de Almeida apresentou alguma queixa ao governador referente a atuação dos soldados. Sendo assim, no ano seguinte à chegada de novos homens pretos ao local da feira, foi tomada a decisão de mandá-los embora e contratar outros homens da escolha do superintendente e capitão. Provavelmente a preferência do superintendente era por soldados brancos, mesmo que eles recebessem um ordenado maior do que seus antecessores.

"Como a experiência tem mostrado que nos soldados de Henrique Dias não há que escolher, procurará o capitão Luis Pereira homens brancos que substituam a sua falta dando se lhe mais dois vinténs por dia e ao Senado da Camara mando fazer esta advertência para que fique entendendo a resolução que tomei"233

Reparem que mais uma vez os soldados brancos receberam um soldo maior se comparados ao pagamento efetuado aos homens pretos do terço de Henrique Dias. Todavia, os serviços prestados por eles eram estimados por uma parte considerável dos funcionários régios que reconheciam suas qualidades e peculiaridades na hora da ação. Em 1739, o conde de Galveas não economizou elogios ao citar a importância de continuidade e manutenção do terço que por muitas vezes passou por dificuldades financeiras para pagar o soldo de seus quadros. Na ocasião, o governador frisou a capacidade deles em se enfiar nos matos na captura de presos pelo Recôncavo e sertões, executando tarefas que somente eles seriam capazes de finalizar com sucesso. Ao que tudo indica, estes homens eram encaminhados para as diligências mais perigosas e arriscadas. Fica também evidente na documentação o papel dos soldados do Terço dos Henrique Dias em limpar e manter o asseio das fortalezas de Salvador, tarefa considerada de menor prestígio e possivelmente desprezada pelos demais militares brancos ou tidos como brancos. ${ }^{234}$

\footnotetext{
231. Luiz Geraldo Silva. "Sobre a 'etnia crioula': o Terço dos Henriques e seus critérios de exclusão na América portuguesa do século XVIII." Renato Pinto Venâncio (org.) Administrando Impérios. Portugal e Brasil nos séculos XVIII e XIX. Belo Horizonte, 2012, vol.1, p. 71-96.

232. APEB. Carta do Governo (à várias autoridades) 1730-1734. Carta ao Capitão Luis Pereira de Almeida. Maço 151. 16 de abril de 1731

233. APEB. Carta do Governo (à várias autoridades) 1730-1734. Carta ao Capitão Luis Pereira de Almeida. Maço 151. 10 de novembro de 1732.

234. "Carta do Conde de Galveas. Bahia, 28 de setembro de 1739”. In: Ignácio Accioli de Cerqueira e Silva. Memórias históricas e politicas da província da Babia, Bahia, 1836, Vol. 3-4, p. 69.
} 
Por algumas vezes o terço foi ameaçado de extinção fazendo com que os oficiais dele enviassem uma petição em 1736 ao vice-rei. Naquele momento, o capitão Miguel de Sousa de Crasto [sic] esforçava-se para manter o terço ainda em atividade, depois de ter passado mais de noventa e sete anos servindo no presídio da cidade, levando cartas à Pernambuco, Minas Novas, Jacobina, Vila de Mocha (na capitania do Piauí). Foram os responsáveis pela segurança do comboio dos quintos reais da capitania da Bahia, auxiliaram na construção da casa de fundição do ouro em Jacobina, desmantelaram um levante ocorrido no forte do Morro [de São Paulo] e por último (porém mais importante para esta dissertação), "assistiram por alguns anos na feira para conduzirem os gados que pagam os quintos de Sua Majestade.”235

Mesmo depois da saída dos soldados pertencentes ao terço dos Henrique Dias de Capuame, a vigilância no momento da feira e condução das boiadas até as portas da cidade de Salvador era feita por homens de patente. Em geral, tenentes, alferes e soldados são mencionados como responsáveis por garantir a reprodução semanal da feira sem o perigo de assaltos e possíveis desvios. $\mathrm{O}$ valor arrecadado pelo donativo cobrado no registro de entrada de gado era sempre encaminhado ao cofre do Senado da Câmara sob a guarda de um militar. ${ }^{236}$ Semanalmente pelo menos uma rês era morta na feira de Capuame para servir de matalotagem ao tenente, soldados e camaradas estacionados naquele sítio.

É inegável - dentro da perspectiva do senhor/proprietário e do Estado a necessidade constante de vigilância sobre as distintas atividades econômicas da colônia com o sentido de garantir a reprodução das condições básicas para viabilizar a exploração da terra e do trabalho. Em todos os ramos e setores produtivos, a vigilância sobre o trabalho (em especial àquele efetivado por homens e mulheres em condição de cativeiro) ocupava uma quantidade significativa de mão-de-obra. Seja interno às unidades produtivas (personificado na figura do feitor sempre atento aos movimentos dos trabalhadores escravizados), seja nas ruas das cidades (através de seus meirinhos, quadrilheiros e militares constantemente à procura de vagabundos e grupos de trabalhadores fazendo "corpo mole" pelas vias públicas), seja os capitães em alto-mar (vigiando de perto os marujos e marinheiros escravizados ou não). $\mathrm{O}$ trabalho improdutivo de policiamento convertia-se paulatinamente em trabalho socialmente necessário na medida em que sem a constante vigilância dos agentes capazes de garantir o mínimo de normatização social, o boicote e a não execução das tarefas estava sempre na eminência de ser um problema para o patrão dos homens livres ou para o senhor dos escravos. Sem a vigilância não haveria trabalho produtivo na colônia, não existiria doutrinamento dos corpos que necessitavam se acostumar a um ritmo árduo e exaustivo de trabalho. Sem a quantidade surpreendente de destacamentos e tropas espalhadas pelas distintas capitanias da América Portuguesa a perambular e fazer sentinela nos caminhos e estradas, a punir os vadios e

235. DH. "Petição que fizeram os oficiais do terço da gente preta desta cidade ao excelentíssimo senhor conde vice-rei" 18 de fevereiro de 1736. vol. 76, p. 345 e segs.

236. AMS. "Livro de Registro de Entrada de Gado" da feira de Capuame (1784-1789). 
andarilhos, a cuidar das cobranças de impostos e arrecadação nos registros de passagem, não haveria exploração econômica viável e muito menos sistema colonial.

\subsection{Cotidiano, sociabilidade e conflito}

As feiras são por excelência os espaços das trocas. Nas mais distintas sociedades, eram notórias enquanto ponto temporário de compra e venda de mercadorias, mas também lugar de troca de saberes e vivências entre pessoas de culturas diferentes, vindas de longe para intercambiar de tudo, inclusive experiências. Ali, a mercadoria tornava-se um mediador evidente das relações sociais. Mas também, na feira fica subentendido que seu papel extrapola os limites da economia. ${ }^{237}$ Os atores deixam de ser momentaneamente meros agentes mercantis para adentrarem um novo universo de sociabilidade. Essa sensação era possivelmente mais perceptível em contextos rurais nos quais muitas pessoas acabavam tendo suas trajetórias cruzadas pelas feiras, estradas e caminhos, eventualmente sentidas como uma quebra do cotidiano. ${ }^{238}$ Mesmo assim, é necessário ter em mente: por mais múltiplas que sejam as vivências e experiências com relação às feiras em diferentes contextos sociais, a mediação necessária, ou pelo menos o seu pretexto último, é a troca de mercadorias. ${ }^{239}$

Enquanto local institucionalizado, a feira garante que a troca tenha um espaço determinado para ocorrer, facilitando assim o encontro entre produtores e consumidores. No caso de uma feira de gado como Capuame, a sua periodicidade religiosamente semanal permitia o mínimo de programação por parte de criadores e marchantes. Todos sabiam que às quartas-feiras a sua demanda pelo comércio daquele gênero especificamente seria atendida, com exceção dos momentos marcados por dificuldades naturais tais como os períodos de grande seca ou as enchentes e interdições de estradas nos momentos de grandes chuvas ou pelos impedimentos impostos pelo calendário litúrgico, tais como a semana da Páscoa.

É comum no Brasil a referência às feiras como espaços de comércio arcaico ainda participantes do cotidiano da população em geral. Todavia, mais folclóricas que as feiras-livres, são as feiras nordestinas. Das feiras mais tradicionais e largamente conhecidas por sua abrangência supra-regional às feiras rurais de caráter local, muitas delas iniciaram a sua trajetória graças ao comércio de gado. Se traçarmos o histórico das feiras nordestinas, é possível perceber que a maior parte delas teve início no século XIX, transformando-se posteriormente em cidades de grande e médio porte. Esse foi o caso de Feira de Santana (Bahia), Feira Grande - conhecida como Mocambo até meados do

\footnotetext{
237. E. P. Thompson. op. cit. p. 201.

238. Fernand Braudel, Civilização material, economia, capitalismo (séculos XV-XVIII), São Paulo, 2009, vol. 2 (Os jogos das trocas), p. 65 e segs.

239. Para um debate sobre os estudos referentes às feiras ainda continua constando como a maior referência a tese de Luiz Mott. Feira do Brejo Grande: estudo de uma instituição econômica num município sergipano do baixo São Francisco. Campinas, Unicamp, 1975.
} 
século XX - (Alagoas), Campina Grande (Paraíba), Areia, Icó (Ceará), Caruaru, Limoeiro, Timbauba de Mocós, Capoeiras (Pernambuco) ${ }^{240}$.

Mesmo que diversos pesquisadores evoquem o passado desta instituição no Brasil como pertencente ao período colonial, com exceção da feira de Capuame e da feira de Goiana, em Cruz das Almas, Pernambuco (ainda não estudada devidamente) ${ }^{241}$, parece não haver mais registros de feiras de gado nas capitanias do norte até as primeiras décadas do século XIX. Pelo fato de muitas delas serem sempre mencionadas de modo vago e sem nenhum embasamento documental, não seria por ora correto afirmar que as feiras nordestinas de gado (adjetivo carregado de significados) tiveram suas raízes inteiramente fincadas no passado colonial. Pelo menos não por um passado marcado pela ampla e pulverizada comercialização de gado vaccum, na medida em que este comércio era fortemente regulado e controlado pelo governo municipal do centro das respectivas capitanias. No caso da capitania da Bahia, todo o gado comercializado fora da feira de Capuame era considerado contrabandeado. Talvez a única exceção seja a das reses vindas dos sertões da Ressaca e regiões próximas ao rio Jequié e Jequiriçá com destino às Vilas de Cachoeira e Santo Amaro. Mesmo nesses casos, o controle era exercido pelas respectivas vilas receptoras dos rebanhos; todavia, faltam pesquisas sobre o abastecimento do Recôncavo para sustentarmos tal afirmação. ${ }^{242}$

Podemos imaginar sim um passado no qual as feiras-livres ou as feiras rurais tiveram um papel importante. Mesmo sem muitas referências documentais, é razoável pensar que praticamente todas as vilas e freguesias mais movimentadas dos sertões possuíam feiras com uma certa periodicidade, ao menos para o final do século XVIII. As vilas do Recôncavo certamente contavam com estes espaços de comércio. ${ }^{243}$ Salvador possuía no século

240. Giovanna de Aquino Fonseca Araujo. Continuidade e descontinuidade no contexto de globalização: um estudo de feiras em Portugal e Brasil (1986-2007). Minho/ Salvador, 2011, p. 39.

241. Não há salvo engano, estudos sobre a feira de gado de Goiana. Por ora, não foi possível precisar a data de estabelecimento da feira. Luiz Mott, "Subsídios à história do pequeno comércio no Brasil", Revista de História. São Paulo, USP, 1976, v. LIII, n. 105. p. 89; AHU. Pernambuco, caixa 28, 20/7/1785 e AHU. Pernambuco, 17 de maio de 1786. Carta do [governador da capitania de Pernambuco], José César de Meneses, à rainha [D. Maria], sobre as providências da Junta da Fazenda referente à feira de gados de Goiana. Há menção da necessidade de transferência da feira para o sítio das Tabatingas, no sentido de manter um maior controle e impedir que os criadores vendessem o rebanho fora da feira. DH. 6 de agosto de 1802. vol. 92, p. 170.

242. No incidente envolvendo o marchante Sebastião de Aragão, atuante na feira de Capoame, e portanto licenciado para exercer a atividade pela Câmara Municipal de Salvador, demonstra a existência de um comércio de gado também nas Vilas de Santo Amaro e Cachoeira. Em junho de 1798 o litoral passava por um momento de carestia da carne-verde devido ao longo período de chuvas que assolara a capitania. Havia uma dificuldade generalizada de transportar o gado no inverno com pontes quebradas, rios cheios, lamaceiros. A falta de carne também era sentida na feira de Cachoeira. O marchante, então, disse às autoridades municipais que "costuma ir comprar gado no lugar chamado Curralinho e conduzí-los para os currais desta cidade. Há 15 dias comprou um lote de gado e passando pela Vila de Santo Amaro e depois estando no distrito de São Francisco, foi parado pelo Juiz Ordinário daquela vila que o queria obrigar a voltar para lá cortar a carne." APEB. Correspondência recebida pelo governo. Senado da Câmara da Bahia (1783-1799). 11 de junho de 1798.

243. Idem. 
XVIII uma feira no Terreiro de Jesus. ${ }^{244}$ Não foi possível localizar a antiguidade da feira do Sete em Salvador, mas pesquisadores afirmam que na enseada de Águas de Menino (para onde a feira do Sete foi transferida no começo do século XX) funcionava desde o século XVII uma feira móvel. Depois do incêndio criminoso que destruiu as barracas da feira de Águas de Menino, ela foi levada definitivamente para São Joaquim. ${ }^{245}$ Fora as eventuais feiras, a cidade de Salvador foi sempre percorrida pelas famosas escravas de ganhos, quitandeiras e outras vendedoras e vendedores ambulantes, responsáveis por boa parte do comércio a retalho feito abertamente nas ruas da primeira capital, como bem retratou Richard Graham. ${ }^{246}$

$\mathrm{Na}$ própria região de Capuame foram encontradas menções à feira de Aramary ${ }^{247}$ e à feira da Bandeira. ${ }^{248}$ Ambas foram citadas somente uma vez em documentação esparsa sendo difícil um mapeamento do caráter e das atividades estabelecidas nos respectivos locais. Devido à proibição da existência de outro ponto de venda de gado em pé concorrente à feira de Capuame, tudo nos leva a crer que nenhuma delas comercializava os "bixanos", sendo possivelmente feiras-livres e pontos de venda de artigos diversos e produtos agrícolas. Era comum que as feiras nordestinas dos séculos XIX e XX fossem divididas internamente em mais de uma feira: a feira de gado e a feira-livre funcionando em locais próximos, mas separadamente. No caso da Feira de Santana, a comercialização do gado em pé, por exemplo, só podia ocorrer no campo da Gameleira, um pouco mais distante da capela de Santana, espaço central da feira durante o século XIX. ${ }^{249} \mathrm{Na}$ medida em que Aramary aparece como uma feira pertencente à intendência de Capuame, é razoável pensar na hipótese de ser uma feira-livre próxima à feira de gado.

Em carta de 3 de abril de 1798 os oficias da Câmara Municipal de Salvador, justificaram a falta de carne pela abominável ação dos atravessadores. Os infratores deixaram de ir para além do registro de Cajueiro comprar gado pelas estradas, uma vez que passaram a negociar os rebanhos na própria feira de Cajueiro. O mesmo comércio ilícito podia ser facilmente verificado segunda-feira na feira-livre de Santana de Catú, terça-feira em Pojuca e quarta-feira na feira da Mata de São João. Sendo assim, o gado, quando chegava à Capuame já teria passado pelas mãos de quatro ou cinco atravessadores com preços finais exorbitantes. Foi solicitado pelas autoridades municipais que ao menos dois soldados andassem pelo interior, indo de feira

244. DH. "Portaria que se remeteu ao Senado da Câmara sobre se fazer feiras alguns dias da semana no Terreiro de Jesus.” 17 de fevereiro de 1719. vol. 87, p.138.

245. Marcia Regina da Silva Paim. Do Sete a São Joaquim: o cotidiano de "mulheres de saia" e homens em feiras soteropolitanas (1964-1973). Salvador, 2005.

246. Richard Graham. op. cit.

247. APEB. Livro de Notas. Livro 83. "Procuração bastante que faz Manoel Fernandes Xaves soldado da feira de Aramary, intendência da Capuame." 1747, fl. 218v.

248. Os funcionários da Câmara em 1767 reclamam das inúmeras irregularidades cometidas pelos marchantes, dentre elas o costume de fazer irregularmente uma feira de gado no sítio da Bandeira. AMS. Atas da Camara (1765-1776). 10 de abril de 1767, fl. 53.

249. Rollie Poppino. Feira de Santana. Salvador, 1969, p. 57. 
em feira para evitar tais trâmites comerciais. ${ }^{250}$ Impossível dizer se a medida surtiu o efeito desejado.

Para as capitanias do Sul, é conhecida a informação da existência de uma feira colonial no Rio de Janeiro. Na Fazenda Santa Cruz, importante ponto de abastecimento da segunda capital colonial, havia um registro de entrada de gado onde atuavam os marchantes, mas em nenhum momento os pesquisadores mencionam a existência de uma feira de gado no local. De lá, as boiadas seguiam pela "Estrada Intendente Magalhães" até chegarem no Largo do Campinho. ${ }^{251} \mathrm{Na}$ região do Campinho (compreendendo hoje Morro do Dendê, Cascadura e Madureira), havia no século XVIII uma feira de gado. ${ }^{252} \mathrm{~A}$ feira de São Cristóvão foi criada em 1813 como ponto exclusivo da venda dos animais.$^{253}$ A feira de muares de Sorocaba talvez seja a única do período colonial devidamente estudada. Por lá também era feito o comércio do gado vaccum. ${ }^{254}$ Salvo engano, não há (estranhamente) menção a feira alguma na extensa e movimentada capitania das Minas Gerais para o século XVIII. 255

É comum a ideia de que os moradores das áreas rurais iam no máximo uma vez por semana e no mínimo uma vez ao ano à vila mais próxima fazer eventuais compras dos artigos que não produziam em suas terras. Era também a ocasião para assistirem à missa ou participarem de algum festejo (muitas vezes religioso). A ida até o centro da vila ou freguesia podia ser aproveitada também para comercializar uma parte da safra que excedesse ao necessário para o sustento da família. A venda de excedente da produção agrícola certamente ganhou uma forma mais generalizada com a ampliação da necessidade do pagamento de impostos ou do arrendamento da terra, caso não fosse permitida a contribuição em gêneros. Talvez por intermédio de atravessadores ou por conta própria, o certo é que, querendo ou não, a necessidade de monetarização crescia, mesmo a passos lentos no meio rural. Todavia, não esqueçamos: dentre as formas de negociação das transações comerciais, prevalecia o sistema de crédito. ${ }^{256}$

A imagem de uma feira eventual criada em um ambiente cuja população ainda não era obrigada a consumir a ponto de justificar a existência de uma centro comercial permanente, com armazéns e lojas de portas constantemente

250. APEB. Correspondência recebida pelo governo. Senado da Camara da Bahia (1783-1799). 3 de abril de 1798.

251. Georgia da Costa Tavares. A atuação dos marchantes no Rio de Janeiro colonial. Estratégias de mercado e redes de sociabilidade no comércio de abastecimento de carne verde (1763-1808). Rio de Janeiro, 2012. p. 65

252. Ronaldo Luiz Martins. Mercadão de Madureira: caminhos de comércio. Rio de Janeiro, 2009, p. 26

253. Pedro Henrique Pedreira Campos. Nos Caminhos da Acumulação: negócios e poder no abastecimento de carnes verdes para a cidade do Rio de Janeiro, 1808-1835, UFF, Niterói, 2007, p. 37.

254. Aluísio de Almeida. Tropeirismo e a feira de Sorocaba. Sorocaba, 1986; Carlos de Almeida Prado Bacellar. Viver e sobreviver em uma vila colonial: Sorocaba, séculos XVIII e XIX. São Paulo, 2001.

255. O trabalho de Flávio Marcus da Silva sobre abastecimento na Capitania de Minas Gerais durante o século XVIII não menciona nenhuma vez a existência de feiras de nenhum tipo no espaço estudado. Flávio Marcus da Silva. Subsistência e poder. A política de abastecimento alimentar nas Minas Setecentistas. UFMG, Belo Horizonte, 2002.

256. Raphael Freitas Brito. "Devo que pagarei": sociedade, mercado e práticas creditícias na comarca do Rio das Velhas (1713-1773). UFMG, Belo Horizonte, 2005. 
abertas, talvez faça sentido para o caso dos sertões baianos. Fora as grandes e movimentadas vilas sertanejas, tais como Jacobina, Rio de Contas mas principalmente Juazeiro, há poucas evidências documentais sobre a existência de um mínimo centro comercial permanente em muitas vilas até o final do século XVIII.257 Para esse fenômeno, temos várias explicações plausíveis, dentre eles o óbvio da população residir majoritariamente em fazendas e sítios, além de produzirem largamente aquilo que consumiam, sem criação (muitas vezes cultural) da necessidade de uso de produtos alheios. ${ }^{258}$ Segundo Fernand Braudel, até o século XVIII, boa parte da vida rural mantinha-se fora ou parcialmente fora do mercado. Àqueles que iam eventualmente à vila ou à feira comprar ferro para a charrua, vender ovos para pagar impostos, mas mantinham-se majoritariamente com o que produziam ou com o que trocavam com o vizinho "não está verdadeiramente associado às trocas do mercado". 259

O comércio de modo geral ocorria nas estradas ou em algumas movimentadas paragens específicas que justificavam o estabelecimento de vendas sem qualquer especialização no comércio de produtos determinados. Era comum unidades produtivas situadas nas beiradas dos caminhos mais frequentados possuírem armazéns ou pousos como a Fazenda Brejo do Campo Seco, localizada na região do Rio de Contas. ${ }^{260}$ Tropeiros, mascates, caixeiros e todo o tipo de vendedores ambulantes, sacoleiros que iam de porta em porta, deviam ser frequentemente avistados pelas estradas sertanejas. ${ }^{261}$ Viandantes ${ }^{262}$, andarilhos e $\operatorname{ciganos}^{263}$ certamente estavam entre os responsáveis por este comércio informal, quase invisível aos olhos

257. APEB. Antonio José Viera Araujo 08/3359/01 Joazeiro 1806 dentre outros.

258. A auto-suficiência era comum a muitas das grandes propriedades rurais nas quais os fazendeiros possuíam escravos especializados em diversos ofícios, além do acesso facilitado a matéria-prima para confecção de inúmeros produtos por contra própria. Não são muitos os documentos para o século XVIII que nos permitem analisar sistematicamente tal informação. Todavia, o caso dos fazendeiros do Campo Seco, estudados por Lycurgo do Santos Filho parece ser um bom exemplo da economia interna a uma grande fazenda de gado. Curioso notar também que desde meados do século XVIII possuíam também um armazém na propriedade. Lycurgo do Santos Filho. op. cit.

259. Fernad Braudel, op. cit. , p. 42.

260. Interessante notar que o roteiro produzido por Joaquim Quaresma Delgado levando em conta o trajeto da cidade de Salvador, até Minas Novas, passando por Jacobina e Rio de Contas possuí várias referências diretas à existência de pontos de comércio de mantimentos pelos caminhos. "Roteiro de Joaquim Quaresma Delgado”. Erivaldo Fagundes Neves e Antonieta Miguel (org.). Caminhos do sertão: ocupação territorial, sistema viário e intercâmbios coloniais dos sertões da Babia, 2007.

261. Laura de Mello e Souza. "Formas provisórias de existência: a vida cotidiana nos caminhos, nas fronteiras e nas fortificações." Fernando Antonio Novais (org.) História da vida privada no Brasil. Vol. 1: Cotidiano e vida privada na América Portuguesa. São Paulo, 1997. p. 41- 81; Antonio Otaviano Vieira Junior. "Das Minas ao Cariri: trajetória de uma família no Ceará (séc. XVIII)." XVI Encontro Nacional de Estudos Populacionais. Caxambu, 2008.

262. No inventário post-mortem do comerciante estabelecido na Passagem do Joazeiro chama a atenção a quantidade de viandantes que apareceram em seus Livros de Conta como devedores. APEB. Antonio José Viera Araujo 08/3359/01 Joazeiro 1806.

263. Erivaldo Fagundes Neves. "Mouros, Judeus, ciganos: origens portuguesas de famílias do Alto Sertão da Bahia”. Erivaldo Fagundes Neves (org.) Sertões da Babia: formação social, desenvolvimento econômico, evolução política e diversidade cultural. Salvador, 2011. 
contemporâneos sempre mediados por aquilo que foi documentalmente registrado.

Neste cenário, as feiras rurais figuravam como o momento de quebra da monotonia cotidiana. Dia de ir para a vila, assistir missa, acompanhar eventualmente uma cerimônia de casamento ou batizado, uma festa dedicada a um dos muitos santos e santas do universo católico e comprar um pedaço de tecido, ferramentas, algum metal necessário aos concertos domésticos e da fazenda. Oportunidade de vender farinha de mandioca, rapadura, cachaça, fumo de rolo, algum doce em conserva feito com açúcar, leite, queijo, requeijão, ${ }^{264}$ sal $^{265}$, comidas preparadas, cuscuz, mugunzá, carne-seca, paçoca, tapioca e artigos fabricados com couro e madeira (oratórios, bancos), redes e artigos religiosos ${ }^{266}$. Brincos, esporas, louças, roupas, selas e até mesmo armas aparecem frequentemente nos inventários post mortem das mulheres e homens sertanejos. Quem sabe também não eram comprados eventualmente nas feiras?

Ali também poderia ser a oportunidade para fechar alguns acordos comerciais $^{267}$ e até mesmo negociar safra de produtos agrícolas, contratar carretos de mercadorias ou a condução de alguma boiada que seria encaminhada para outras regiões. A feira se transforma em modo geral no ponto de encontro de comerciantes e clientes. É o momento das dívidas serem saldadas, dos contratos serem firmados e as transações, realizadas. Quase tudo na base do crédito.

A mobilidade dos moradores sertanejos do século XVIII ainda precisa ser melhor estudada, mas tudo leva a crer que eram em geral homens e mulheres das estradas e dos caminhos, cujo deslocamento facilitava ainda mais a interação de mundos distintos e o intercâmbio cultural, contribuindo para a formação de sertões verdadeiramente mestiços. ${ }^{268}$ Certamente uma análise mais detalhada tendo por base as "Dispensas e Processos Matrimonial"269,

264. São vários os pesquisadores que afirmam a inexistência do hábito de consumir manteiga ente os sertanejos no período colonial. A argumentação em geral segue o relato de alguns viajantes e o evidente calor e problemas no eventual amarzenamento do preparado. A dificuldade de acesso ao sal também seria uma evidência. Todavia, é comum nos sertões atuais encontrar a famosa manteiga de garrafa. Sobre a inexistência de consumo de manteiga até fins do século XIX, ver: Lycurgo dos Santos Filho, op. cit. e Manuel Correia de Andrade. Áreas de domínio da pecuária extensiva e semi-intensiva na Babia e Norte de Minas Gerais. Recife, 1982,p. 74.

265. O sal era considerado estanco Real até 1801. Teoricamente só poderia ser consumido e comercializado o sal que vinha das regiões de extração localizadas em Portugal. Todavia, a existência de lambedouros e pontos de extração do sal tornavam a população em alguns locais menos dependente do caro produto cuja quantidade ínfima importada não dava conta de fornecer a todos. Myriam Ellis. O contrato do sal no Brasil Colonial. São Paulo, USP, 1955.

266. É interessante reparar na quantidade de imagens de Santas e Santos que aparecem nos inventários. Este assunto será retomado com maiores detalhes na terceira parte do segundo capítulo.

267. Fernand Braudel, op. cit., p. 72 e segs.

268. Isnara Pereira Ivo. Homens de caminho: trânsito, comércio e cores nos sertões da América Portuguesa. Século XVIII. UFMG, Belo Horizonte, 2009.

269. Este tipo de fonte documental é comumente localizado entre os manuscritos guardados nos Arquivos das Cúrias Metropolitanas. Com base no acervo vinculado à cidade de São Paulo, Maria Aprecida Menezes Borrego conseguiu reconstruir a trajetória de vários comerciantes estabelecidos na 
guardado nos arquivos eclesiásticos, seria capaz de dar uma dimensão da constante itinerância à qual estiveram submetidos diversos homens e mulheres sertanejos. Miguel Lourenço de Almeida, por exemplo, era natural de Portugal, morou na vila da Barra no sertão de Rodelas, voltou a Portugal para finalmente se estabelecer na fazenda Brejo do Campo Seco, na vila do Rio de Contas, em 1755. ${ }^{270}$ Casou-se com Ana Francisca da Silva, natural do porto e freguesia do Urubu. O neto do primeiro dono da fazenda, por sua vez, morou no norte da capitania de Minas Gerais, na região do rio Jequitinhonha, marcando assim um perfil possivelmente generalizado sobre a caráter móvel das famílias dos sertões setecentistas.

Era comum que os fazendeiros e comerciantes tivessem dívidas com moradores de vilas distantes (até mesmo de outras capitanias) mostrando assim o frequente deslocamento desta população. Os agentes, produtores e comerciantes formadores de verdadeiros circuitos mercantis tinham certamente como ponto de encontro eventuais as feiras. E visto o intenso movimento de criadores, condutores e todo tipo de agente mercantil por Capuame, é razoável supor que os homens sertanejos aproveitavam a situação para firmar acordos comerciais. Podemos observar a quantidade de dívidas ativas e passivas de pecuaristas e donos de armazéns com moradores e comerciantes da região onde ficava a feira de Capuame.

Segundo o inventário post-mortem do criador de gado Antonio João da Silva, aberto em 1804, quase toda a família do finado morava no sítio da Barrinha, localizado na Missão da Passagem do Juazeiro termo da Povoação de São José da Barra do Sento Sé (vila de Jacobina). Possuíam onze escravos e uma quantidade considerável de gado na Fazenda das Lajes. Somente um filho do inventariado morava fora: Eugênio Furtuoso da Silva, residente em Mata de São João. Dentre as dívidas ativas, três foram contraídas por crédito à moradores de Mata de São João: Manoel Martins de Carvalho, Manoel Lopes da Conceição (marchante), Francisco Machado de Souza. As demais eram devidas a moradores de fazendas próximas ou localizadas na freguesia de Xique-Xique. Muitas delas contabilizadas em boi. ${ }^{271}$ Certamente o falecido circulava pela freguesia onde estava a feira de Capuame, local de morada de um de seus filhos, para comercializar parte do gado que produzia.

Paulino Pereira e Rosa Barbosa eram naturais da freguesia de Santo Antonio do Pambu. Moravam na Fazenda Pancarahy, na comarca de Jacobina. Certamente o casal foi envolvido com criação de gado, todavia, o inventário foi aberto quando os dois já tinham morrido e possivelmente com bastante idade, visto o filho mais velho de Rosa, fruto do primeiro casamento, ter mais de quarenta anos. Ficou órfão um filho de tenra idade. Certamente não era cria legítima de Rosa. Deixaram algum dinheiro de contado, ouro, mas somente dois escravos e doze cabeças de gado. Entretanto, o mais importante aqui é notar as dívidas: Antônio de Abreu devia um cavalo ao casal. Pegou o animal

antiga capitania. Maria Aaprecida Menezes Borrego. A teia mercantil: negócios e poderes em São Paulo colonial (1711-1765). São Paulo, USP, 2006.

270. Lycurgo dos Santos Filhos. op. cit.

271. APEB. Antonio João da Silva 08/3406/04 Jacobina 1804 
para ir até a cidade da Bahia. José Martins da Cruz, vaqueiro da Fazenda das Lajes também tinha de pagar uma determinada quantia em dinheiro aos herdeiros do casal. Será que a dívida era resultante de alguma negociação de rebanho? $\mathrm{O}$ mais interessante são as dívidas que o casal tinha com figuras da freguesia da Mata de São João: Padre Francisco Machado, Caetano de tal e o marchante Francisco Pereira. ${ }^{272}$

Outro morador no Pancarahy possuía dívidas nos arredores da feira de Capuame. Desta vez se tratava do dono da fazenda Pancarahy, Pedro José de Souza. Senhor de onze escravos, tinha mil cabeças de gado, doze cavalos e sessenta potros em sua propriedade. Devia uma quantidade não especificada a Domingos Dias de Andrade, residente em Mata de São João. Por tratar-se de dívidas entre 3:100\$000 a 300\$000, é de se imaginar que a quantia devida também estava entre estes dois valores. ${ }^{273}$ Segundo os "Livros de Registro de Entrada de Gado", Domingos Dias de Andrade era alferes. Entre os dias de feira no qual aparece seu nome, foi possível diagnosticar a presença de duas situações distintas. A primeira diz respeito às vezes em que Domingos Dias de Andrade aparece somente com o qualificativo alferes, encaminhando gado que ficava solto em alguma propriedade da região da feira de Capuame, tais como a fazenda de Vasco Marinho, Emboacica, Moita ou na sua própria fazenda. $\mathrm{Na}$ segunda situação, o alferes Domingos Dias de Andrade era designado como o responsável por levar gado a cidade de Salvador com os dizeres "para suprir a cidade". Possivelmente era o responsável por socorrer a capital em momentos de carestia e conduzir as reses em período de necessidade, na medida em que não era nem marchante e nem aparecia como um mero criador.274 Certamente, enquanto homem de patente, o alferes fosse o militar responsável por tomar bois nos sertões baianos para abastecer a capital nos momentos de falta do mantimento.

Um certo Francisco Martins da Cruz, possivelmente parente próximo do vaqueiro da Fazenda das Lajes, José Martins da Cruz, também devia ao fazendeiro Pedro José de Souza o valor de 730\$000. A informação consta declarada em uma parte destacada, não estando junta com as demais dívidas arroladas. Será que se tratava de alguma boiada recentemente negociada? Por enquanto, não há como saber.

O casal Rita Maria da Conceição e Francisco Gomes da Cruz eram grandes produtores de gado, além de comerciantes. Possuíam doze escravos e três fazendas: da Aldeia e do Porteiro na Ribeira do Salitre e a fazenda das Manissobas na beira do Rio São Francisco. Tinham uma casa na missão do Juazeiro e mais alguns imóveis que não constam no inventário por faltar uma página do documento manuscrito. Ao que tudo indica, o casal atuava também na extração de sal visto estar entre os bens arrolados no documento uma barca e uma bomba de cobre de desaguar barca, "30 couros de rês crus para ensacar

\footnotetext{
272. APEB. Paulino Pereira e Rosa Barbosa 08/3406/08 Jacobina 1814

273. APEB. Pedro José de Souza 08/3507/04 Jacobina 1797.

274. AMS. "Livros de Registro de Entrada de Gado" da feira de Capuame.
} 
o sal". Das dívidas arroladas, aparece um certo José de Castro, morador em Mata do São João. ${ }^{275}$

Antonio Alves de Lemos era comerciante em Mata de São João. Seu inventário menciona a existência de dois livros de assento contendo várias informações sobre dívidas, mas infelizmente um se achava queimado no momento em que morreu. Um dos livros, segundo descrição do próprio inventário, possuía transcritas as dívidas arroladas que algumas pessoas contraíram com ele pelo comércio de "carne de açougue". Por falta de mais indicativos, é difícil saber com qual tipo de negociação o comerciante estava envolvido. Não aparecia como um dos marchantes da feira de Capuame, mas certamente participava ao seu modo das negociações envolvendo gado, carne e couro. Dentre as pessoas que contraíram dívida com o comerciante, estava Manoel Lopes da Conceição (citado também no inventário de Antônio João da Silva) e o marchante Floriano do Rego (seu compadre já falecido) a quem emprestou um cavalo de 25 mil réis e nunca mais foi devolvido. Dentre os bens arrolados no documento, é possível notar a grande quantidade de couros, solas de boi, meias de sola, além da balança de arame do armazém usada para pesar ouro e a quantidade de vinte e sete oitavas de "galam de prata".,276

Antonio Alves de Lemos possuía não só o armazém, mas também quartos de aluguel na região. Talvez os alugasse para viandantes que passassem temporadas na feira de Capuame, ou para os marchantes que viviam entre idas e vindas da cidade de Salvador à freguesia da Mata de São João. Era irmão da Santa Casa de Misericórdia, participante das irmandades das Almas e São Gonçalo. Materializou sua devoção na construção de uma casa de oração, próxima as outras casas de aluguel, junto a sua morada. $\mathrm{Na}$ capela continha uma imagem de Bom Jesus da Piedade com dois palmos ou mais de altura e os aparelhos de prata, uma imagem de Nossa Senhora da Piedade aos pés da cruz e um Santo Antonio. Tanta devoção não impedia que guardasse com muito cuidado suas propriedades e bens materiais: em meio a sua rede de tanga feita de corda, tamborete, canastra, talha de barro e os artigos de couro, havia também uma espingarda Lazarina e um bacamarte. ${ }^{277}$

Mas nem só de comerciantes e feira de gado fez-se os arredores de Capuame. $\mathrm{Na}$ freguesia da Mata de São João havia uma quantidade significativa de sítios, fazendas, mas principalmente engenhos. Ao norte do engenho da Mata - já apontado como propriedade da Casa da Ponte, onde eventualmente ficava pastando gado da feira de Capuame - havia o engenho do Coqueiro. A propriedade era do português natural do arcebispado do Porto, Capitão Manoel dos Santos Vieira Pais. Na fazenda localizada na estrada que ia para a Igreja do Bonfim da Mata trabalhavam setenta e seis escravos. A sede era uma casa avarandada, com sete quartos e demais cômodos, ricamente mobiliada. Quarenta e cinco bois mansos se revezavam no movimento das moendas. Os bois, assim como os garrotes e vacas paridas

\footnotetext{
275. APEB. Rita Maria da Conceição 08/3507/02 Jacobina 1791.

276. APEB. Antonio Alves de Lemos 03/1141/1610/07 Mata de São João 1812.

277. Idem.
} 
certamente eram originários de uma de suas sete fazendas de gado localizadas na vila de Itapicuru de Cima. Tinha como procurador no sertão o sargentomor João Dantas dos Reis Portátil, estudado por Monica Dantas em "Fronteiras Movediças". ${ }^{278} \mathrm{O}$ capitão possuía uma casa em frente à Igreja Matriz do Nosso Senhor do Bonfim da Mata, possivelmente mais perto da feira de Capuame, bem como uma fazenda de cana arrendada no Engenho da Mata com tarefas de cana caiana, além de casa de farinha e alambique. ${ }^{279}$

O inventário de Mariana Ferreira de Souza foi o único da freguesia da Mata de São João a citar diretamente a feira de Capuame como local de morada. Era natural da Mata, foi casada com o falecido comerciante português Antonio Silva. Certamente morreu com idade bem avançada e sem muitos bens materiais, na medida em que possuía somente uma escrava já idosa, uma ovelha, um caixão usado e uma caixa de jacarandá no momento de sua morte. ${ }^{280}$

Para a feira de Capuame não iam somente os homens ligados diretamente ao comércio de gado, sendo possivelmente frequentada por pessoas que viam na movimentação semanal uma oportunidade de vender mercadorias ou prestar serviços. É razoável supor que as boiadas vindas dos sertões baianos não chegavam pontualmente na quarta-feira, dia em que ocorria o registro do gado e o encaminhamento das boiadas para a cidade de Salvador. Sendo assim, os arredores da feira possivelmente passaram a ganhar com o tempo uma estrutura mínima para receber uma quantidade significativa de pessoas que permaneciam no máximo uma semana no local. Evidente que estamos falando de homens acostumados a montar acampamento e pousar em qualquer lugar, sob qualquer condição. Para aqueles adaptados a dormir com um olho aberto e outro fechado nas paragens à beira de estradas, sempre com o risco de assalto, ataque indígena ou presença de onças e outros animais, dormir em um lugar movimentado e vigiado como uma feira já seria sinônimo de relativo momento de "baixar a guarda". Mas certamente, comerciantes aproveitavam a ocasião para oferecer aos viajantes algum tipo de conforto atípico para o descanso dos trabalhadores depois de semanas na estrada. A existência de pousos é frequentemente citada na região da feira de Capuame desde pelo menos a década de $1730 .{ }^{281}$ As tavernas e casas de jogos também são mencionadas pelas fontes documentais, aparecendo em especial nos processos criminais. ${ }^{282}$ Lojas e armazéns, espaços de venda de alimentos preparados, negras de ganho e até mesmo prostitutas deviam circular com frequência por aquelas bandas, assim como em qualquer lugar no qual parasse

\footnotetext{
278. Monica Duarte Dantas. Fronteiras Movediças: a comarca de Itapicuru e a formação do arraial de Canudos (relações sociais na Bahia do século XIX), São Paulo, 2007.

279. APEB. Custodia Maria Moreira. 03/1141/1610/01 Mata de São João 1818.

280. APEB. Mariana Ferreira de Souza 03/1141/1610/05 Mata de São João 1827.

281. Erivaldo Fagundes Neves. "Mouros, Judeus, ciganos: origens portuguesas de famílias do Alto Sertão da Bahia”. Erivaldo Fagundes Neves (org.) Sertões da Babia: formação social, desenvolvimento econômico, evolução política e diversidade cultural. Salvador, 2011, p. 68.

282. APEB. Câmara para o Governador, 12 de março de 1806, maço 209-1, doc. 108.
} 
uma quantidade significativa de homens que viviam em constante deslocamento.

Manoel Felix da Veiga era um marchante, comerciante, além de dono da fazenda de gado Boqueirãozinho, localizada no sertão de Sento Sé, com uma quantidade grande de reses. "Estabelecido em mercancia, tinha muitas correspondências para o Recôncavo e sertões desta Bahia e Capitania, assistindo muitos engenhos." Possivelmente aproveitava as redes mercantis conquistadas através do comércio de gado para negociar outros tipos de mercadorias que constavam também em seu armazém localizado na cidade de Salvador. ${ }^{283}$

Possivelmente os arredores de Capuame era tomado por estabelecimentos em que distintos produtos eram negociados tendo por pretexto a movimentação existente na feira. É razoável pensar que comerciantes estabelecidos em Salvador, cidade portuária e ponto de entrada de distintas mercadorias, utilizassem de algum modo a estrutura da feira de Capuame para comercializar ou até negociar o frete e transporte de produtos ou encomendas para os sertões, uma vez que os condutores e demais trabalhadores voltavam desimpedidos para suas terras. Importante lembrar que muitos fazendeiros também eram negociantes e contraíam corriqueiramente dívidas com comerciantes da praça de Salvador, veremos alguns casos destes circuitos mercantis no decorrer do segundo capítulo.

O trânsito colonial era decerto bem intenso. Percorrendo estradas e caminhos, vivenciando experiências provisórias e momentâneas, muitos eram os negócios e acordos firmados por pessoas das mais diferentes partes da colônia. Trataremos deste assunto com mais detalhes no segundo capítulo. No momento o que importa é pensar na feira de Capuame como quebra temporária do cotidiano, assim como ponto constituidor de laços mercantis estabelecidos entre comerciantes que negociavam mercadorias para além do gado em pé.

A feira de Capuame certamente era o ponto de comércio semanal mais movimentado para além das ruas de Salvador. A mais importante feira de gado da colônia e quiçá, a primeira feira da América Portuguesa. Poucos foram os espaços desse porte no século XVIII. Talvez algumas feiras nas vilas e freguesias mais movimentadas. Ainda falta muita pesquisa sobre este espaço tão folclórico quanto as feiras brasileiras, em especial as feiras nordestinas. Conhecidas pelo seu falatório, discussões acaloradas, preços sendo barganhados em meio a brincadeiras e frases prontas. $O$ fato é que pouco sabemos sobre como eram esses espaços no século XVIII. Não temos nem ao menos um levantamento que faça estimativa do número de feiras rurais para o período setecentista em contexto sertanejo, exceto a contribuição do Prof. Dr. Luiz Mott em artigo escrito na década de 1970. 
Já no século XIX, com um maior adensamento populacional e a diminuição do tamanho das pequenas e médias unidades produtivas 284 , decerto o comércio sertanejo cresceu. $\mathrm{E}$ a testemunha deste processo é um sem-número de feiras cuja origem data deste período. Daí em diante as feiras nordestinas são mais facilmente mapeadas. Os produtos comercializados são visualizados com mais facilidade pelo pesquisador. Artigos de couro, manteiga de garrafa, farinhas, tipos diferentes de feijões e leguminosas eram encontradas com facilidade nas feiras. Talhos de carne verde cortados na hora, carne-seca, couro e certamente o gado em pé fazia parte da paisagem das muitas feiras nordestinas inauguradas no decorrer do século XIX. Talvez a mais bem estudada seja Feira de Santana, local para onde a feira de gado abastecedora da cidade de Salvador foi transferida na década de 1830.285 Espaço constantemente movimentado, contando com a passagem semanal de três a quatro mil pessoas vindas de diferentes lugares, sua posição geográfica estratégica permitiu que fosse sem dúvida a maior feira de gado do nordeste. Por ela passavam quatro estradas diferentes que ligavam os sertões ao litoral.286 Não foi à toa que lá se desenvolveu o mais vultuoso ponto de contrabando do século XVIII.287 E evidentemente, não foi por um acaso que as autoridade provinciais fizeram questão de deixar de lado a feira de Capuame para transferi-la para uma encruzilhada tão movimentada.

Espaço de espera, a feira é o ponto aglutinador por excelência. E assim como qualquer lugar no qual há uma quantidade significativa de pessoas circulando, a possibilidade de desavença é eminente. Pensando especificamente no caso da feira de Capuame, muitos dos conflitos ali travados tinham relação direta ou indireta com o comércio do gado: principal produto e leitmotiv de existência daquele espaço de comércio. Seja os litígios entre funcionários e marchantes referente às proibições impostas ao comércio, seja os desacordos entre criadores e marchantes sobre o preço do gado e o prazo para o pagamento do lote, nem sempre respeitado pelos compradores do gado em pé.

Importante lembrar que a feira de Capuame não era um espaço de comércio livre propriamente dito no que diz respeito à compra das boiadas, visto só poderem ser vendidas aos marchantes licenciados. Ali, o gado em pé poderia ser vendido por qualquer criador ou condutor vindo diretamente da unidade produtiva, mas não era qualquer pessoa que podia comprar as reses e sair com elas da feira. Muitos foram os debates sobre a inviabilidade de todos os criadores levarem por sua própria conta as boiadas até Capuame, sendo

\footnotetext{
284. Sobre o processo de diminuição das fazendas, ver: Erivaldo Fagundes Neves. Uma comunidade sertaneja. Da sesmaria ao minifúndio: um estudo de história regional e local. Feira de Santana, 2008.

285. Rodrigo Freitas Lopes. Nos currais do matadouro público: o abastecimento de carne verde em Salvador no século XIX. (18 30-1873), UFBA, Salvador, 2009, p. 37

286. Rollie Poppino. Feira de Santana. Salvador, 1969.

287. A ação dos atravessadores era tão intensa que próximo ao ano 1801 foi instalado um registro de entrada de gado em Olhos D'Agua só para as autoridades poderem garantir que as reses que ali passassem fossem diretamente para Capuame, tamanho o número de estradas e caminhos passiveis de conduzir facilmente as boiadas certamente desviadas sem muito pudor. AMS. "Livro de Partes e Ofícios da Administração da Feira. (1801-1810)”
} 
observado em alguns anos de existência da feira a permissão para que os marchantes pudessem ir até o sertão comprar gado; até mesmo em momentos de carestia era comum que militares, sob o comando dos capitães dos distritos sertanejos fossem os responsáveis por encaminhar as boiadas até a feira de Capuame.288 Não devemos descartar a possibilidade e viabilidade desta norma ser burlada a ponto de facilitar ainda mais o contrabando e a nãopassagem das boiadas pelo registro, na medida em que era absurdamente difícil a fiscalização dos caminhos. Havia uma dificuldade principalmente em garantir a veracidade das informações sobre a origem do gado que chegava na feira sendo comum a notícia de atravessadores se dizerem criadores de gado. ${ }^{289}$

Desta maneira, por mais que qualquer criador, condutor ou pessoa, autorizada ou não, pudesse ir até Capuame e vender o gado, o controle era muito mais rigoroso em relação aos compradores. Só podia comprar gado na feira de Capuame os marchantes licenciados que tivessem autorização da Câmara Municipal de Salvador para atuar. Entre os anos de 1784 e 1789, ou seja, o período correspondente ao primeiro "Livro de Registro de Entrada de Gado" da feira de Capuame, temos uma relação de quarenta marchantes, nem sempre atuantes todos simultaneamente. Eles apareciam toda a semana pela feira e eram os únicos que podiam comprar o gado sertanejo. ${ }^{290}$

Fora os marchantes, as únicas pessoas que podiam sair da feira de Capuame após registrar devidamente a quantidade de gado na casa da superintendência eram os criadores e condutores que provassem ir cortar por sua própria conta os bovinos nos currais da cidade ou os criadores que encaminhassem gado sobejo para o Recôncavo; todos com autorização prévia do governador. ${ }^{291}$ Ou seja, sem autorização dos vereadores ou do governador não saía uma rês sequer da feira de Capuame. Pelo menos teoricamente.

Pelo número limitado de marchantes atuantes no comércio e pela quantidade de criadores e condutores que precisavam voltar à Capuame de tempos em tempos para saldar as dívidas com os compradores à crédito das boiadas, a maior parte dos conflitos certamente envolviam pessoas que em geral se conheciam relativamente bem por passarem com uma certa frequência por Capuame, gerando rivalidades de longa data entre as partes envolvidas nos quiproquós.

Esse foi o caso concreto das desavenças entre o capitão Joseph Luis da Silva e o escrivão do da feira de Capuame, João Moreira Velho. Era terminantemente proibido aos criadores de gado vender qualquer boi depois de lançá-los nos "Livros do Registro de Entrada". Ao produtor ou condutor, havia duas alternativas: ou ele vendia a boiada para um dos marchantes

\footnotetext{
288. Em geral quando havia falta de carne em Salvador, os militares entravam com o gado trazidos dos sertões aparecendo nos documentos o número de reses e o termo "Para suprir a cidade". AMS. "Livros de Registro de Entrada de Gado" da feira de Capuame (1784-1789)

289. APEB. Senado da Camara de Salvador Correspondência recebida (1786 - 1822). aço 485-2. 14 de abril de 1804. fl. 26 e segs.

290. AMS. "Livros de Registro de Entrada de Gado" da feira de Capuame (1784-1789)

291. AMS. Ofícios do governo (1712-1737); AMS. "Livro de Registro de Entrada de Gado" da feira de Capuame (1784-1789)
} 
presentes na feira ou ia até a cidade de Salvador com licença concedida pelo Senado para cortar a carne por conta própria em um dos açougues públicos espalhados pela capital. Nem sempre as normas eram respeitadas pelos frequentadores de Capuame. $\mathrm{Na}$ primeira feira de abril, no dia 6 do ano de 1752, o capitão Joseph Luis da Silva foi um dos homens responsáveis pela infração. Ele e seus sócios compraram gado do criador Alexandre de Carvalho depois do registro nos livros da superintendência. Percebendo a infração, o escrivão foi pessoalmente interferir na transação comercial.

O capitão Joseph Luis da Silva, considerando a interferência um desaforo vindo de um escrivão (cuja função não era regular sobre as vendas na feira) descompôs o funcionário com "postura petulante e injuriosa." Entre as várias trocas de xingamentos e acusações ficou evidente que a briga tornou pública uma antiga rixa pessoal. O escrivão João Moreira Velho era o sucessor do tio da mulher do capitão. Joseph Luis da Silva, por sua vez, considerava que o cargo havia sido roubado, gerando grande mágoa e descontentamento com o fato de João Moreira Velho ocupar o ofício antes vinculado a seu parente. Houve também alguma história anterior com relação as chaves da casa da superintendência e os cuidados com o registro, mas o episódio não foi bem relatado no documento produzido pelo próprio escrivão. ${ }^{292}$

Todavia, de todos os conflitos documentados envolvendo frequentadores da feira de Capuame, o mais intrigante foi a acusação dos moradores da região de Mata de São João contra os disparates e desmandos corriqueiramente efetuados pelo superintendente Antonio Xavier de Brito, tornando o caso público após a tentativa de assassinato do mulato André Corcino da Silva, relatado no início do capítulo. No episódio, põe-se em questão o policiamento na região e a tentativa de controle para além da âmbito estritamente comercial, na medida em que os perseguidos eram homens cuja única "infração" eram ser pobres e desocupados. ${ }^{293}$

Frequentada por pessoas que permaneciam somente alguns dias da semana pelas redondezas em instalações precárias aguardando a hora de fecharem o negócio e poderem voltar para o seu lugar de origem, a feira mostrava-se como mais um dos pontos criados pela itinerância característica tanto dos homens sertanejos, quanto do comércio volante do período setecentista. Todavia, o constante vai e vem estava vinculado sobretudo ao incessante deslocar imposto pela atividade criatória das regiões de produção extensiva. Mesmo permanecendo como traço cultural vinculado fortemente à realidade e formação dos sertões baianos, a pecuária deixou marcas indeléveis em boa parte do interior das capitanias da América Portuguesa. Empurrando fronteiras, preparando o terreno para a efetivação do domínio colonial, sem dúvida foi uma das atividades econômicas mais importantes para a formação da sociedade setecentista. Espaço de trânsito, assim como os caminhos e

\footnotetext{
292. AMS. "Registro da carta do escrivão da feira de Capuame João Moreira Velho" 6 de abril de 1752 e "Registro de uma carta ao superintendente da Feira que faria pelo escrivão da Camara desta Cidade." 19 de abril de 1752 fl. 37.

293. APEB. Câmara para o Governador, 12 de março de 1806, maço 209-1, doc. 108.
} 
estradas que cortavam o território, a feira de Capuame sem dúvida permitia a efetivação de mais uma forma provisória de existência. ${ }^{294}$

294. Laura de Mello e Souza. "Formas provisórias de existência: a vida cotidiana nos caminhos, nas fronteiras e nas fortificações." Fernando Antonio Novais (org.) História da vida privada no Brasil. Vol. 1: Cotidiano e vida privada na América Portuguesa. São Paulo, 1997. p. 41- 81; Gloria Kok. O sertão itinerante. Expedições da Capitania de São Paulo no século XVIII. São Paulo, 2004. 


\title{
CAPÍTULO 2: OS SERTÕES BAIANOS
}

\author{
"Eu venho de muito longe \\ Eu venho cortando a estrada \\ Com meu laço na garupa \\ Levando a minha boiada" \\ Ponto de boiadeiro. Domínio Público. \\ "Quando matar o boi o mocotó é meu \\ Qué pra pagar o trabalho, ô baiano, que esse boi me deu" \\ Ponto de boiadeiro. Domínio Público. \\ "A liberdade é assim, movimentação" \\ Guimarães Rosa. Grandes sertões: Veredas.
}

Vila de São João da Água Fria, 1771. Uma quadrilha especializada em roubar gado nas estradas e fazendas sertanejas passou a ser investigada pelo Juiz Ordinário da comarca. Segundo as testemunhas arroladas no processo - a maior parte composta por homens brancos, criadores de gado da região próxima a freguesia de São José das Itapororocas, termo da vila de Cachoeira o bando causador do pânico na região era formado por escravos fugidos e forros residentes nos arrebaldes da movimentada vila do sertão. ${ }^{1}$

Manoel Gonçalves (moço, morador na Fazenda Cipipira), Manoel Carvalho (escravo da administração de Santa Bárbara do poço do Capim), João da Costa (mestiço forro) e Gonçalo (criolo que fugiu das Galés da cidade da Bahia) estavam unidos para furtar bovinos, éguas e cavalos que passassem em uma das principais estradas dos sertões em direção a cidade de Salvador, atravessando a feira de Capuame. $^{2} \mathrm{O}$ bando composto por negros escravizados ou forros andava sempre fortemente armado com espingardas, catanas, facas de arrasto e facas de ponta. Eram publicamente conhecidos pelos delitos cometidos, especialmente um certo Luis Francisco, homem forro, morador na Borda da Mata de Baixo. Eram temidos pelos viandantes,

1. APEB. Secção Colonial. Maço 201-1. Correspondência recebida pelo Governo da Bahia diversas autoridades. Correspondência para o governo da Capitania do Juiz ordinário da Vila de S João da Agua Fria (13/03/1771) doc. 13

2. A Estrada das Boiadas que ligava os sertões baianos desde o Piauí, rio São Francisco até a feira de Capuame passava obrigatoriamente pela região de São José das Itapororocas e Água Fria desde o início do século XVIII. Sua posição chave desde o período colonial foi ressaltada por Rollie Poppino. Feira de Santana, Salvador, 1969, p. 68. 
comboieiros e moradores das redondezas pela ousadia e valentia com que agiam. Apesar de ser público e notório o nome e o local de morada dos autores das desordens executadas nas fazendas e estradas, ninguém era capaz de enfrentar os bandidos. Nem mesmo as autoridades locais.

Dentre os crimes estava o costume de roubarem alguns escravos das fazendas - especialmente as escravas - que passavam a acompanhá-los durante as andanças. O caso mais escandaloso e conhecido foi o sequestro da negra pertencente à Francisco Alvares Pinheiro. A cativa ficou escondida temporariamente na casa de Manoel Gonçalo. Sua morada parece ter servido muitas vezes como esconderijo de escravos fugidos. João da Costa (mestiço forro) era morador da fazenda chamada dos Vermelhos, possivelmente uma referência à presença indígena na região. Também foi acusado de roubar uma escrava e um cavalo à Luis Teixeira de Carvalho. Testemunhas descreveram também o roubo do cavalo do filho de José de Souza Araújo, morador no sertão de Paramirim, executado pelo cabra Manoel de Carvalho. Leandro de Almeida Pamplona (pardo casado) e Manoel Paiva (crioulo forro) moravam nos arrebaldes da vila e também foram apontados como afamados ladrões de gado da região.

Sempre acompanhados por escravos para cujas fugas contribuíram, costumavam passar na porteira da fazenda Canabraba, segundo relato de Felix Pereira de Araújo, com bois e vacas de outras pessoas, estando soltos, amarrados com uma corda ou puxados pelos cavalos. Não possuíam mais nenhum ofício do que roubar o gado e ir vender em outras regiões distantes.

Mais um bando atuava na região. Desta vez um dos envolvidos era homem branco: Francisco Gonçalves Oliveira (moço, filho de Joana Maria Rodrigues) atuava junto com seu sócio, José Soares de Almeida (pardo, forro, morador nos arrebaldes da vila), e o pardo Bento da Cruz que era morador no Engenho do Bom Jardim e servia de condutor do gado furtado. Os três tinham fama pela valentia com que atuavam. Roubavam os bovinos, iam ao encontro do dono do rebanho para ameaçá-lo de morte caso se atrevesse a fazer qualquer tipo de denúncia. Andavam sempre armados e não temiam justiça alguma, nem a divina e muito menos a mundana. Francisco Gonçalves Oliveira já tinha sido preso, mas logo foi solto "por empenho". Este "por empenho" constante no documento não explica muito sobre o modo como Francisco conquistou a liberdade.3 Só é possível saber por enquanto que viviam juntos às suas amásias e podiam facilmente ser observados tirando os sinais e marcas das reses furtadas, para dificultar a localização do verdadeiro dono do rebanho.

De acordo com o testemunho dado por Felipe de Magalhães Cerqueira, 31 anos, morador na Fazenda Apriada, foi possível ver mais de uma vez o bando dos negros forros e escravos negociar gado com comerciantes nas

3. Agradeço a observação de André Nicácio sobre o fato de que nas constituições dos Estados liberais do século XIX o termo "por empenho" equivaler a uma espécie de "fiança". Todavia, esta fiança também não tinha um carater unicamente vinculado ao pagamento de uma quantidade determinada em dinheiro. 
portas da fazenda do Salgadinho. Disse que todo o trâmite era feito com pagamento em bois, sendo um dos principais da quadrilha o escravo Manoel Carvalho que não prestava a menor obediência ao administrador da fezanda de Santa Bárbara do poço do Capim, de onde era cativo. Certa vez, o vaqueiro mulato de Felipe Magalhães fez comentários sobre os furtos de Manoel Carvalho, provocando a ira do escravo que foi até a porta da casa do vaqueiro ameaçá-lo de morte com uma faca de ponta. Não fosse o vaqueiro correr imediatamente para dentro de sua morada, teria sido morto por cutiladas.

Os moradores da fazenda Mombaça também observavam com frequência o trânsito dos escravos e forros assaltantes das estradas. José Martins Valverde viu passar pela cerca de seu sítio várias vezes o escravo Manoel Carvalho conduzindo bois e vacas amarrados até o sítio de Manoel Gonçalves, moço, em Cipipira, onde cortavam clandestinamente talhos de carne. Lá, o pai Manoel Gonçalves, velho, ajudava a refugiar muitos escravos. O local foi referido pela testemunha como se tratasse de um mocambo. Segundo o mesmo relato, era comum avistar o criolo Gonçalo, fugido das Galés, pois costumava andar pelas estradas roubando com duas escravas fugidas.

Luiz Teixeira de Carvalho, pardo, forro, criador de gado e lavrador na fazenda Rio do Peixe foi o único a enfrentar um membro do bando. No episódio em que teve seu cavalo roubado por João da Costa, chamou mais dois homens que seguiram e intimaram o ladrão até fazer com que ele devolvesse o animal furtado. Reparem que esta foi a única testemunha parda e forra arrolada no processo. Luiz Teixeira disse possuir Manoel (cabra) dois cachorros bravos, além de morar escandalosamente com o mulato Dizidério, escravo de Sebastiana, residente na fazenda da Formiga. O pai do cabra Manoel de Carvalho, escravo da administração de Santa Barbara do Poço do Capim, era Francisco da Costa, homem vermelho, ou seja, indígena. Certamente a mãe de Manoel era cativa. Francisco da Costa também morava no Poço do Capim e usava "de matar reses no mato e fazer moquem para secar a carne e trazer para casa para comer". ${ }^{4}$

Visto grande parte das reses roubadas estar com um pedaço suspeito do couro faltando por ser necessário retirar a marca da ferra do verdadeiro dono do rebanho para despistar supostos curiosos ou investigadores, é provável que os bovinos frutos de roubo não passassem por Capuame, mesmo que fosse sob a guarda de um criador falso. Certamente um rebanho inteiro com as marcas faltando levantaria de imediato suspeitas. Ninguém arriscaria passar por um local altamente vigiado como a feira de gado. Deviam seguir em descaminho até o Recôncavo, entrando para a capital de barco. ${ }^{5}$ Podiam ser também vendidos em outras unidades produtivas e engenhos (como disse uma das testemunhas) que consumiriam os animais prontamente para apagar as pistas sobre o crime. Provavelmente uma parte das reses era consumida pelo

4. APEB. Maço 2010-1. Correspondência para o governo da Capitania do Juiz ordinário da Vila de $\mathrm{S}$ João da Água Fria (13/03/1771) doc. 13

5. APEB. Maço 485-1. Senado da Câmara de Salvador Correspondência recebida (1786 - 1822), 11 de março de 1801, fl. 13. 
próprio bando ou talvez vendida nas imediações em forma de carne-seca, como relatou Luiz Teixeira de Carvalho.

Não é de se estranhar que o bando de cativos e forros contasse com uma quantidade tão grande de membros. Possivelmente era necessário muitos homens para render os comboios de boiadas sertanejas compostos por aproximadamente sete a dez homens armados. Será que as diversas mulheres escravas presentes no bando serviam também para distrair os viandantes e facilitar os assaltos?

O distrito de Água Fria já era conhecido desde o início do século XVIII como lugar de contrabando e descaminho de gado, sempre destino final de diligências militares obstinadas a prender ladrões, atravessadores e contrabandistas. ${ }^{6} \mathrm{Na}$ década de 1790 a região próxima à fazenda Santana de Olhos D'água, na freguesia de São José das Itapororocas (ainda termo da vila de Cachoeira), começou a despertar a atenção das autoridades pela quantidade de ocorrências de furtos e por ser reconhecidamente ponto de contrabando, devido à facilidade de fuga pelos muitos caminhos que entrecortavam aquelas paragens. Não foi à toa que lá decidiram estabelecer o registro de entrada de gado de Santana destinado a inibir os descaminhos e para lá transferiram, na década de 1830, a feira de gado responsável pelo abastecimento de Salvador. ${ }^{7}$

Certamente as paragens mais próximas à vila de Água Fria e a freguesia de São José das Itapororocas deveriam requerer atenção redobrada dos criadores e condutores do gado sertanejo que passassem por aquelas bandas. Era ponto obrigatório de travessia para muitos viandantes, por ser entroncamento de ao menos quatro estradas vindas de pontos diferentes dos sertões. ${ }^{8}$ Qualquer perda no rebanho equivaleria ao prejuízo aproximado de 1:000\$000 (um conto de réis), similar a quase um ano de produção pecuarista para as fazendas de médio e grande porte. Se os cuidados para com o gado estivessem sob a supervisão de um trabalhador livre ou escravo, a situação poderia ser ainda mais complicada. Como justificar ao patrão o prejuízo correspondente a uma ano de trabalho de muitos cativos e homens livres?

\footnotetext{
6. DH. "Carta que se escreveu ao Capitão-mor Baltasar Vanhique, e ao Capitão João de Seixas Ferraz para fazerem vir todas as boiadas, que àquele distrito da Água Fria chegarem, para esta cidade. " 18 de setembro de 1705, vol. 41, p. 131; DH. "Carta que se escreveu ao Capitão-mor Baltasar Vanique sobre fazer vir boiadas para sustento do Povo desta cidade" 2 de junho de 1706 , vol. 41, p. 183; DH. "Ordem para o Capitão-mor Belchior Vanique para fazer conduzir para esta cidade todo o gado que chegar a Água Fria ” 23 de outubro de 1711. vol. 53, p. 101; DH. "Carta que se escreveu ao Capitão de Cavalos Pedro de Araújo Vilas Boas para mandar preso o Tenente da sua tropa " 4 de janeiro de 1713 , vol. 42, p. 93; DH. “Carta que se escreveu ao Capitão-mor do distrito de Água Fria " 10 de outubro de 1718. vol. 43, p. 141; DH. "Carta para o Tenente Coronel José de Toar de Ulhoa, sobre mandar prender a Manuel de Oliveira, morador em Maragogipe." 11 de dezembro de 1724, vol. 72, p. 5; DH. "Portaria para o Escrivão da Câmara da vila de São João de Água Fria." 16 de junho de 1734, vol. 74, p. 316. DH. "Portaria para os oficiais da Câmara da vila de São João de Água Fria " 30 de janeiro de 1734 , vol. 74 , p. 257 ;

7. Rodrigo Freitas Lopes. Nos currais do matadouro público: o abastecimento de carne verde em Salvador no século XIX. (18 30-1873), UFBA, Salvador, 2009, p. 37.

8. Rollie Popino. op. cit. p. 68.
} 
Fortemente armados, protegidos pelas orações e mandingas materializadas em patuás ${ }^{9}$, balangandãs, escapulários e santinhos, iam os condutores por longas estradas repletas de perigos e surpresas. Atravessando rios caudalosos em épocas de chuva; enfrentando dias de ausência completa de água nos momentos de seca; dormindo de modo altamente improvisado, com "um olho aberto e o outro fechado"; permanecendo por semanas ou meses fora de casa; assumindo as estradas como lar e os companheiros de viagem como familiares, seguiam passadores, condutores, vaqueiros e boiadeiros. Livrando-se de possíveis assaltos, acertos de contas, animais ferozes e ataques indígenas, continuavam a reproduzir a sociedade colonial sertões adentro rumo à Capuame.

\subsection{Pecuária e territorialidade colonial}

É inegável e já bem versada a importância da pecuária enquanto atividade econômica através da qual foi possível o processo de territorialização colonial, "definido pela generalização de relações sociais de produção voltadas para possibilitar a acumulação de capital "10, por intermédio da expansão das fazendas de gado assentadas nas terras apropriadas em forma de sesmarias ${ }^{11}$, depois de estarem livres dos indígenas sistematicamente exterminados ou aldeados. $^{12}$

Considerada sempre como atividade subsidiária, estrela de segunda grandeza quando comparada à mineração e à grande lavoura, a pecuária auxiliou a conversão do vasto território em área produtiva (na perspectiva da Coroa), condição básica para a confirmação das sesmarias, além de ter papel imprescindível para a dinâmica de acumulação primitiva de capital ( não conquistada com base no entesouramento ou por vias naturais, mas graças à coerção e exploração violenta da terra e do trabalho ${ }^{13}$ em contexto

9. Luiz Mott. "Quatro mandingueiros do sertão da Jacobina nas garras da Inquisição". Babia: Inquisição e Sociedade. Salvador, 2010, p. 121-169.

10. Ana Carolina Gonçalves Leite. A modernização do V ale do Jequitinhonha mineiro e o processo de formação do trabalhador "bóia-fria" em suas condições regionais de mobilização do trabalho . USP, São Paulo, 2010. p. 16. Ver também: Renata Santos Rente. Região Geográfica e o regional na literatura brasileira: a representação do sertão em Guimarães Rosa e os debates sobre a formação do Brasil, São Paulo, USP, 2013, p. 51.

11. Sobre as condições e o sistema de doação de sesmarias, ver: Marcia Maria Menendes Motta. "Sesmeiros e posseiros nas malhas da lei." Nas Fronteiras do poder: conflitos de terra e direito agrário no Brasil de meados do século XIX. Unicamp, Campinas, 1996. p. 150 e segs.

12. Pedro Puntoni. A Guerra dos Bárbaros: povos indígenas e a colonização do sertão Nordeste do Brasil, 16501720. São Paulo, 2002.

13. Falando sobre o processo de territorialização colonial do interior através da pecuária, Ana Carolina Gonçalves Leite estabelece a relação deste movimento com a acumulação primitiva de capital: "tais relações de produção, embora se organizem de maneira a permitir a acumulação de capital, se estabelecem num contexto particular, e não-autonomizado, de articulação entre terra, trabalho e capital, determinado pela colonização. São relações que não aparecem como propriamente capitalistas - ou ainda, especificamente capitalistas, como quer Martins (2004) - porque as condições para que a reprodução ampliada do capital se estabeleça com base na mais-valia relativa ainda não estão postas, embora tais relações cumpram o papel de promover a acumulação primitiva metropolitana. O longo processo de autonomização entre a terra, o trabalho, o capital e o Estado, e, por sua vez, entre os agentes que personificam tais categorias, corresponde, desta forma, à acumulação primitiva, na medida em que esta é também processo de acumulação categorial das formas autonomizadas da relação- 
mundializado, na medida em que trouxe as condições básicas para a ocupação e exploração econômica do solo interiorano transformado em região cujas relações sociais e de produção se davam em grande medida nas unidades produtivas de caráter extensivo, mediado pela mercadoria gado necessária para a reprodução diária da colônia. ${ }^{14}$

O papel da pecuária na frente de expansão das colônias do Novo Mundo pode ser observado tanto nos domínios ingleses dos Estados Unidos e Jamaica ${ }^{15}$, quanto no interior das colônias espanholas substancialmente ocupadas por fazendas de gado ${ }^{16}$; cada qual com sua particularidade, mas todos envolvidos dentro da mesma lógica de conversão das terras recémconquistadas, após conflitos e expulsões dos indígenas, em possessões europeias coloniais. ${ }^{17}$

Facilitado pela criação extensiva e pela necessidade de pouca mão-deobra, o processo de montagem das fazendas de gado requeria poucos recursos a depender mais da expulsão dos primeiros habitantes autóctones e do alargamento das fronteiras coloniais em relação aos terrenos em que ainda não podiam penetrar devido a supremacia indígena preponderante em vários pontos dos sertões baianos entre os séculos XVII e XVIII.

A tendência geral no período estudado foi uma ampliação da soberania lusitana; todavia, o domínio por parte da Coroa portuguesa não era algo dado e em vários pontos foi configurado muito mais por retrocessos do que por avanços na expansão. É necessário lembrar que até o século XVII a colonização era categorizada pela sua reversibilidade, ${ }^{18}$ consolidando-se somente com a mineração e o final da guerra dos bárbaros. Com suas fronteiras abertas, foi somente graças a muito derramamento de sangue e

capital. ” p. 82-83. Em nota sobre o conceito de mais-valia, referindo-se ao debate sobre o estatuto do trabalho escravo no Antigo Sistema Colonial, continua: "Contudo, convém precisar que o fundamento da relação na qual Marx (vol. I, t. I) enxerga a extração de mais-valia é a igualdade formal dos indivíduos livres que promovem a troca de coisas que lhes pertencem como propriedade, oferecendo o vendedor/trabalhador sua mercadoria força de trabalho por um período determinado, em troca do capital variável pago a ele na forma de salário. Por sua vez, a relação mediada por coisas no escravismo colonial é a que se processa no tráfico, no qual se equiparam possuidor do escravo e possuidor de capital dinheiro, os únicos que apresentam igualdade formal e que são sujeitos das mercadorias que personificam. Deste modo, para qualificar o excedente produzido no emprego do escravo como fator de produção, a mais-valia não se apresenta como o conceito mais preciso. Ainda assim, cabe considerar que a produção de mercadorias fundada na utilização do trabalho escravo implica na produção de "fortuna monetária" (Marx, vol. IV, cap. XX), que aparece como lucro." Ana Carolina Gonçalves Leite, op. cit., p. 106.

14. Renata Santos Rente, op. cit. , p. 57.

15. Douglas Hall. In Miserable Slavery: Thomas Thistlewood in Jamaica, 1750-86. London, 1989 e Trevor Burnard. "The sexual life of an Eighteenth-Century Jamaican Slave Overseer." Mastery, Tyranny, and Desire: Thomas Thistlewood and His Slaves in the Anglo-Jamaican World, 2004.

16. Interessante notar que o mesmo discurso sobre um solo não muito propício para a agricultura também aparece nos estudos sobre as possessões da América espanhola. Sobre a expansão das estâncias no México, ver: François Chevalier. La formacion de los latifundios em México. Haciendas y sociedad em los siglos XVI, XVII e XVIII. México, Fondo de Cultura Econômica, 1976, p. 171 e segs.

17. Stuart Banner. How the indians lost their land: law and power on the frontier. London, 2007

18. Márcio Roberto Alves dos Santos. Fronteiras do sertão baiano : 1640-1750, São Paulo, USP, 2010. p. 24 e 393. 
concentração de recursos e esforços neste sentido que a soberania europeia se efetivou. ${ }^{19}$

A ocupação dos sertões baianos pelas fazendas de gado vaccum, portanto, não ocorreu de modo contínuo. ${ }^{20}$ Assemelhando-se muito mais a manchas esparsas pontilhando as vastas terras interioranas, penetrando apenas onde era permitido pelas circunstâncias, só foram estabelecidas unidades produtivas nas áreas gradualmente desembaraçadas da presença indígena ou com o solo mais próximo a rios e regiões menos escarpadas, com condições mais favoráveis para a exploração econômica. Aqui vale pontuar algumas considerações sobre o processo de territorialização colonial e a formação dos sertões baianos. Em primeiro lugar, é necessário ter em mente que o interior da capitania da Bahia e adjacentes sofreram diversas alterações no decorrer dos anos. Os sertões baianos do século XVII não eram iguais aos do século XVIII e muito menos àqueles descritos para o período oitocentista. Isso dito, equivale a afirmar que a região jamais pode ser caracterizada como um local a-histórico, pautado por uma estrutura econômica e social estagnada, como querem alguns historiadores. ${ }^{21}$

Se no século XVII eram majoritariamente dominados pelos múltiplos grupos indígenas que se deslocavam constantemente pela hinterlândia, ${ }^{22}$ no século XVIII, com a nova configuração imposta pela presença portuguesa, os sertões baianos foram rearranjados de acordo com o novo contexto no qual foram formados. ${ }^{23}$ Fazendas de gado foram estabelecidas, áreas indígenas mantiveram-se sempre que possível. Quilombos e comunidades rurais formadas por posseiros permaneciam em terras de difícil acesso ou ainda não devidamente esquadrinhadas pelos funcionários régios e sesmeiros ${ }^{24}$.

As fronteiras abertas permitiam a reprodução de modos de vida distintos daquele imposto pelo domínio colonial. Mas não duraram muito. Conforme avançava o processo de territorialização, as unidades produtivas da mercadoria gado se multiplicavam. Todavia, até mesmo sobre a disseminação das fazendas

\section{Pedro Puntoni, op. cit.}

20. Marcio Santos. op. cit.

21. Dentre todos os estudiosos, talvez aquele que tenha influenciado mais a historiografia dedicada aos sertões no sentido de propagar uma imagem de economia atrofia e sertão a-histórico tenha sido Caio Prado Junior. Formação do Brasil Contemporâneo. São Paulo, 1986.

22. Há um vasta literatura sobre a movimentação indígena pelo o interior da América nos séculos iniciais: Pedro Puntoni, op. cit:; Jonh Manuel Monteiro. Negros da Terra: indios e bandeirantes nas origens de São Paulo. São Paulo, 2000; Nadia Farage. As muralbas dos sertões: os povos indígenas no Rio Branco e a colonização. São Paulo, 1986; Maria Hilda Boqueirão Paraíso. O tempo da dor e do trabalho: a conquista dos territórios indigenas nos sertões do Leste. São Paulo, 1998, entre outros.

23. Sobre a formação dos sertões ver sobretudo os trabalhos de Erivaldo Fagundes Neves, em especialmente, Estrutura fundiária e dinâmica mercantil: alto sertão da Babia, séculos XVIII e XIX. Salvador, Feira de Santana, 2005.

24. Interessante traçar uma história retrospectiva sobre os quilombos e comunidades fundos de pastos existentes aos montes no território baiano para pensarmos criticamente na permanência destes espaços de sombra mesmo diante do processo de modernização a qual os sertões estão submetidos desde o século XX. Faz-se necessário ainda um trabalho que pretenda mapear todos os quilombos, aldeias indígenas e comunidades de fundo de pasto da Bahia e arredores. Muito nesse sentido tem sido feito pelo Laboratório Geografar vinculado à UFBA. Para uma análise crítica ao processo de modernização, ver: Ana Carolina Gonçalves Leite, op. cit.; Renata Rente, op. cit. 
de gado vaccum, vale uma adendo. Nem todos os currais eram convertidos absolutamente em centros produtores voltados para o mercado. Foram várias as pequenas comunidades que se reproduziam através do uso coletivo da terra ocupada de múltiplas maneiras. Os grandes sesmeiros não conseguiam ocupar por conta própria todas as terras que recebiam. Eram obrigados a delegar a terceiros tal função. Seja através de foreiros, rendeiros ou posseiros, muitos dos efetivadores diretos da ocupação territorial foram as pessoas mais pobres, aquela "gente menos importante," sem títulos e patentes. ${ }^{25}$ A pressão sobre estes homens da "ínfima plebe", ex-moradores pobres das vilas litorâneas, membros menos destacados das tropas e "jornadas do sertão", fugitivos e degredados só se efetivaria de modo irreversível depois da década de 1850, com a pressão após a abolição do tráfico negreiro e principalmente a conversão da terra em capital. Antes disso, a abundância de terra (em especial nos sertões baianos) não havia promovido um fechamento completo das fronteiras, encerrando o ciclo de longa duração caracterizado pelo processo de territorialização da região.

É possível esquematizar e periodizar o processo de ocupação paulatina de algumas regiões pelos primeiros sertanistas e missionários que foram seguindo os principais rios perenes. A finalidade de apresentar este esquema está para além de um mero didatismo. O processo de territorialização respeitou uma lógica que deixou marcas indeléveis sobre a dinâmica de produção e de abastecimento de carne aos principais centros consumidores do século XVIII. Este esquema nos ajudará a entender quais eram as áreas que mais abasteciam a feira de Capuame e por quê. Até mesmo os motivos de ocupação em cada uma das distintas paragens sertanejas se deram por fatores diferentes, mantendo coerência e sentido vinculado aos demais elementos que impulsionaram o processo de interiorização em cada um dos sertões.

Primeiramente, faz-se necessário definir o conceito de sertões baianos, para além da acepção do termo "sertão" enquanto sinônimo de interior ou como mera contraposição à paisagem geográfica do litoral. Sem entrar no mérito de toda a carga pejorativa e preconceituosa que a ideologia do progresso trouxe sobre a ideia de "sertão" e do "ser sertanejo", 26 neste estudo o conceito é sempre pensado no plural ( ou seja, estamos falando dos sertões) para frisar seu caráter múltiplo enquanto regiões distintas e historicamente construídas. Fora alguns traços capazes de dar coerência e aparência de formação de um conjunto, os sertões se diferenciavam muito entre si. Tirando a predominância da pecuária enquanto atividade econômica mais disseminada e a distância em relação ao litoral, o sertão do Jequitinhonha, da Ressaca, da Jacobina e do Piauí, possuíam menos semelhanças entre si nos séculos XVII e XVIII do que podemos imaginar. $\mathrm{E}$ as distinções estavam para muito além das diferenças meramente naturais.

\footnotetext{
25. Kalina Vanderlei Silva. Nas solidões vastas e assustadoras: a conquista do sertão de Pernambuco pelas vilas açucareiras nos séculos XVII e XVIII. Recife, 2010; Guilhermo Palacios. Cultivadores libres, Estado y crisis de la sclavitud em Brasil em la epoca de la Revolución Industrial. México, 1998.

26. Para uma abordagem crítica, ver: Renata Rente, op. cit.
} 
Os sertões baianos eram, portanto, as distintas áreas historicamente constituídas, fruto do processo de apropriação das terras em forma de extensas sesmarias, cuja ocupação partiu do centro da capitania da Bahia. Ou seja, considera-se "baiano" o adjetivo que qualifica o movimento de interiorização partindo da cidade de Salvador e seu Recôncavo. Sendo assim, são considerados sertões baianos desde o atual norte de Minas Gerais até o sul do Piauí, tendo como partes integrantes faixas dos atuais estados do Pernambuco, Sergipe e Alagoas. Assim, é possível perceber que a área de influência extrapolava os limites da capitania da Bahia, alterados constantemente. O norte de Minas Gerais, por exemplo, até as primeiras décadas do século XVIII pertenciam a jurisdição da Capitania da Bahia. O caso de Piauí também é emblemático. Colonizada inicialmente por homens vindos em geral da Capitania da Bahia, seu território, por exemplo, entre 17151718 era administrativamente subordinado ao Estado do Maranhão, eclesiasticamente estava vinculado ao Bispado de Pernambuco (com sede em Olinda), mas judicialmente respondia pelo Tribunal da Relação de Salvador na Bahia. ${ }^{27}$ "Era uma rosa-dos-ventos, típica daquelas paragens." $28 \mathrm{O}$ interior da capitania de Pernambuco também foi ocupado por sertanistas saídos da região de Salvador. Mesmo que os limites e fronteiras entre as duas distintas áreas administrativas estivessem em constante alteração e litígio, segundo Capistrano de Abreu, no momento de guerra dos holandeses o movimento de interiorização partindo do litoral da capitania de Pernambuco foi abandonado, tornando obsoleto os caminhos que só voltaram e ser frequentados décadas depois, quando a região já havia sido pisada há muito por baianos. ${ }^{29}$

Talvez a única diferença substancial entre a utilização do conceito sertões baianos enquanto categoria espacial e recorte geográfico adotado na investigação e o termo sertão baiano utilizado por Márcio Santos em "Fronteiras do sertão baiano: 1640-1750", ${ }^{30}$ seja a admissão no presente estudo do caráter múltiplo e plural das distintas partes que formam como síntese o conjunto dos sertões abordados; enquanto no estudo de Márcio Santos admite-se o sertão baiano como unidade cuja área é delimitada por fronteiras marcadas por disputas intrínsecas ao domínio lusitano, mesmo que reconheça e leve em conta o caráter heterogêneo e descontínuo de sua ocupação.

Como será observado mais a frente, as distintas partes do interior da Bahia e adjacentes eram mencionadas pelas autoridades e pelos próprios sertanejos sempre acompanhados pelo qualificativo que denunciava sobre qual sertão especificamente estavam falando. Ou seja, o gado não vinha simplesmente do sertão, ele tinha origem em um sertão determinado: sertão do

27. Charles Boxer. A Idade de ouro do Brasil. São Paulo, 1963, p. 211.

28. Sérgio Buarque de Holanda (direção). História Geral da Civilização Brasileira. Tomo I: A época colonial. Segundo Volume: Administração, economia, sociedade. São Paulo, 1981.

29. Capistrano de Abreu. Capitulos da História Colonial (1500-1800) \& Os caminhos antigos e o povoamento do Brasil. Brasília, 1963, p. 259.

30. Em nenhum momento a distinção visa negar o caráter inovador do trabalho de Márcio Roberto Alves dos Santos que apontou de modo exemplar o caráter múltiplo da ocupação descontínua do interior da capitania da Bahia e adjacentes. A única diferença aqui é a necessidade de reforçar esta variedade através do uso do termo no plural. 
rio São Francisco, sertão do Pajeú, sertão do Jeremoabo e assim por diante. Dito isso, a ideia de pensar os sertões sempre no plural não visa somente frisar uma concepção teórica pautada na observação de documentos sobre os distintos movimentos de ocupação e consolidação de cada uma das partes formadoras da categoria-síntese sertões baianos. O uso no plural condiz também com a visão que os próprios contemporâneos tinham sobre a particularidade de cada uma das regiões. Cada um dos qualificativos trazia consigo diversas referências transmitidas ao interlocutor. Seja o óbvio discernimento sobre a distância ou posição geográfica que estava em jogo, seja as características sociais e históricas compartilhadas pelo sertão específico.

Considerando então os sertões baianos como uma síntese categórica fictícia (criada a posteriori - como todo conceito - para dar inteligibilidade ao conjunto), mas possuidora de uma coerência no que diz respeito à similaridade em relação aos processos históricos de ocupação partindo do centro da capitania da Bahia (e mantendo-se por muito tempo sobre sua influência política, cultural e econômica), podemos dividir a ocupação dos sertões baianos em quatro movimentos distintos, porém sem dinâmicas estanques e rigorosamente sequenciais:

A parte primeiramente apropriada em nome do poder lusitano foi o norte do sertão de dentro, seguindo os rios Real, Inhambupe, Itapicuru, Vaza Barris até chegar ao rio São Francisco. ${ }^{31}$ Devido a constante atuação de missionários e sertanistas que logo cedo se estabeleceram ao norte da cidade da Bahia de Todos os Santos, formando pontos de apoio para a penetração territorial, ${ }^{32}$ até pelo menos metade do século XVII aquela região já se encontrava relativamente mapeada, contando com uma quantidade significativa de fazendas $^{33}$ e aldeamentos ${ }^{34}$ pontilhando o território ainda em processo de expulsão, redução e extermínio de indígenas. Grande parte deste movimento se deve a ação dos primeiros membros da Casa da Torre que tiveram entre seus parentes religiosos responsáveis também pela redução dos indígenas, tais

31. AMS. Atas da Camara (1649-1659), vol. 3. "Termo de juramento que se deu a Bernardo Correa Leitão e Antão de Oliveira para se fazer a repartição do gado do Inhambupe até o Rio de São Francisco da banda dela." 26 de maio de 1651, p. 149; Monica Duarte Dantas. "Povoamento e ocupação do sertão de dentro baiano". Penélope, Oeiras, v.23, p. 9-30, 2000; Felisbello Freire. Historia Territorial do Brazil, vol. 1, (Babia, Sergipe e Espirito Santo), Rio de Janeiro, 1906. Em carta escrita ao Rei em 11 de março de 1595, os governadores mencionam o reconhecimento do Rio São Francisco, a melhor navegabilidade de lá até a cidade de Salvador devido a existência da Torre de Garcia D'Ávila, mas fazem questão de frizar a impossibilidade de penetrarem naquelas partes do território devido a presença beligerante dos indígenas naquele momento. "Sobre as causas do Estado do Brasil". Apêndice I: Biblioteca da Ajuda, códice 44-XIV-6, fl. 179-197v. Diogo Ramada Curto. O Atlântico Sul no século Barroco (1580-1720). 2014 (no prelo).

32. Márcio Roberto Alves dos Santos. op. cit. , p. 286 e segs; Fabrício Lyrio Santos. Da catequese à colonização. Colonização e povos indígenas na Babia (1750-1800). UFBA, Salvador, 2012.

33. AMS. Atas da Câmara (1649-1659), vol. 3, "Cópia da carta do Mestre de Campo General deste Estado." 26 de maio de 1651, p. 144.

34. Os primeiros aldeamentos dos sertões baianos foram estabelecidos inicialmente na parte mais ao norte da cidade da Bahia e foram disseminadas até atingirem o Rio São Francisco sobretudo pelos padres jesuítas. Fabricio Lyrio Santos. op. cit., p. 50 e segs. 
como o Padre Antonio Pereira. Sesmeiro, ${ }^{35}$ possuidor de terras no rio São Francisco, "prático do sertão", mantinha os índios das sesmarias de seus familiares sempre aldeados. Seguia acompanhado por seus escravos e silvícolas percorrendo os sertões, rearranjando espacialmente os aldeias e expandindo a presença da cruz pari passu à da espada. ${ }^{36}$ Permitia que os índios sob sua vigilância fossem utilizados nas expedições e guerras, além de colaborar no desmantelamento de mocambos tais como em Jeremoabo no ano de 1669.37

$\mathrm{Na}$ outra margem do rio São Francisco os sertanistas e sesmeiros seguiam até o sul do Piauí, estando aquelas paragens já relativamente ocupadas, em nome da Coroa portuguesa, em finais do século XVII. De acordo com o relato escrito por Padre Miguel de Carvalho, em 1697, o sertão do Piauí já encontrava-se dividido em freguesias, tomado por fazendas de gado pertencentes majoritariamente a sertanistas vindos da Bahia e entrecortada por estradas que o ligavam também a Maranhão e a Serra de Ibiapaba no Ceará. ${ }^{38}$ Francisco Dias D'Ávila, Bernardo Pereira Gago ( irmão de Francisco Dias D'Ávila), Domingos Rodrigues de Carvalho, Domingos Afonso Sertão e seu irmão Julião Afonso Serra foram os primeiros sertanistas a efetivar o domínio português no território e a conseguir se apropriar das terras em forma de sesmarias depois do extermínio dos índios anaiós no Rio São Francisco e auxílio na redução dos gurguéias. ${ }^{39}$ Todavia, esta primeira investida no sentido de estabelecer fazendas e freguesias no interior do Piauí foi abalado em 1712 por um levante dos indígenas da região, resultando em ataques às fazendas de gado. ${ }^{40} \mathrm{~A}$ investida autóctone não garantiu, todavia, o desmantelamento das unidades produtivas, apesar de uma das características da região ter sido a ocorrência de constantes disputas até o final do século XVIII, tendo por protagonistas os índios pimenteiras e gueguês. ${ }^{41}$

De acordo com Capistrano de Abreu, o avanço baiano pela região dos rios Pajeú e imediações (depois integradas à capitania de Pernambuco) ocorreu simultaneamente ao período em que as vilas litorâneas de Recife e Olinda encontravam-se sob domínio holandês. Pelo fato das estradas rumo ao interior estarem bloqueadas, não havia a partir do litoral daquela capitania um grande movimento sertanista no século XVII. Os caminhos foram deixados livres

\footnotetext{
35. DH. "Registro de uma carta de sesmaria do Padre Antonio Pereira petição que fez a este Governo, e confirmação delle. " vol.19, p. 447.

36. DH. "Regimento, que se passou ao Ajudante Luís Alvares para ir passar as Aldeias da Jacobina para a Serra do Orobô." 21 de dezembro de 1657. vol. 4, p. 58.

37. DH. “Regimento que levou Fernão Carrilho que foi por Capitão para fazer entradas aos mocambos de Geremoabo.” 21 de maio de 1669. vol.4, p. 192.

38. Leonardo Rolim. "Tempo das carnes no Siará Grande": dinâmica social, produção e comércio da carnes secas na vila de Santa Cruz do Aracati (c. 1690-c. 1802). João Pessoa, 2012, p. 62 e 68.

39. Odilon Nunes. Pesquisas para a bistória do Piaui. Vol. 1. Rio de Janeiro, 1975.

40. Charles Boxer. A Idade de Ouro do Brasil (das dores de crescimento de uma sociedade colonial). São Paulo, 1963, p. 209.

41. AHU. Piauí. Caixa 1. 29 de março de 1751. Caixa 5 (1800-1823) Devassa contra os índios Pimenteiras (1804)
} 
para o avanço das tropas e militares baianos ${ }^{42}$, responsáveis inclusive por se apropriar das terras do Porto da Folha, pertencente atualmente ao estado das Alagoas, adquirido e mantido em forma de morgadio pelo patriarca da família Gomes Ferrão Castelo Branco. O sertanista e mestre de campo Pedro Gomes recebeu inúmeras mercês por sua participação direta na guerra contra os holandeses, fazendo com que os neerlandeses perdessem em uma ocasião "uma Companhia de Cravinas, e uma casa forte com trinta flamengos, e quarenta e três índios, e três mil cabeças de gado" na região do rio São Francisco. 43

O segundo fluxo de reconhecimento e ocupação dos sertões baianos partiu do interior das vilas do Recôncavo, na segunda metade do século XVII, no sentido de conter a resistência indígena e os constantes ataques às unidades produtivas da região depois dos desmantelamentos provocados pelas expedições apresadoras de índios para forçá-los ao trabalho compulsório nos engenhos. ${ }^{44} \mathrm{~A}$ guerra dos Bárbaros permitiu aos colonizadores ampliar a área de domínio português, além de garantir o controle sobre a terra circunvizinha ao cinturão já convertido em área produtora de gêneros agrícolas. O curso do Médio Paraguaçu foi um dos primeiros focos da ação das tropas articuladas pelas "jornadas do sertão" para destruir e reprimir duramente a organização dos índios maracás, kiriris, paiaiás, topins e xocós da região. As investidas muitas vezes foram iniciativas de membros das famílias do recôncavo possuidores de patentes. Merece destaque o papel das famílias Adorno e Rodrigues enquanto destacados sertanistas que se embrenharam nas matas dos sertões ainda no século XVI em busca de metais, exterminando e apresando índios para servirem de trabalhadores compulsórios às unidades produtivas no Recôncavo. ${ }^{45}$

Nomeados administradores das aldeias existentes nas sesmarias pertencentes às duas famílias, conseguiram utilizar muitos dos indígenas sob seu poder na guerra travada contra os grupos beligerantes e opositores ao avanço colonial. As próprias guerras foram muitas vezes impulsionadas para garantir a mão de obra necessária depois do assalto dos holandeses a Angola, motivo limitador da continuidade do tráfico atlântico de africanos escravizados. ${ }^{46}$

As guerras no vale do rio Paraguaçu, considerado a "porta do sertão", tiveram início em 1651, a partir da nomeação de diferentes militares para a empreitada. Dentre eles estavam Gaspar Rodrigues Adorno, Agostinho

\footnotetext{
42. João Capistrano de Abreu. Capitulos de história colonial, 1500-1800 \& Os caminhos antigos e o povoamento do Brasil. Brasília, 1963. p. 257-310. p. 259.

43. DH. "Registro de patente de sargento-mor Pedro Gomes Provido de Tenente de Mestre de Campo General deste Estado. ” 23 de fevereiro de 1657. vol. 19, p. 118.

44. Juliana Brainer Barroso Neves. Colonização e resistência no Paraguaçu - Babia, 1530-1678. UFBA, Salvador, 2008.

45. Idem.

46. Wolfgang Lenk. Guerra e Pacto Colonial: exército, fiscalidade e administração colonial da Babia (1624-1654). Unicamp, Campinas, 2009. Luis Felipe de Alencastro. O trato dos viventes: formação do Brasil no Atlântico Sul, século XVI e XVII. São Paulo, 2000.
} 
Pereira, Brás Rodrigues Arzão, Estevão Ribeiro Baião Parente. Avançando pelos sertões de Aporá, Orobó, assaltando as aldeias do Camisão e Maracás, margeando o rio Jequiriçá, garantiram o domínio português em mais uma faixa territorial, abrindo e estruturando caminhos em direção ao interior. ${ }^{47}$

Consolidando a ocupação dos sertões de Itapororocas e as áreas próximas ao rio Jacuípe foram reduzidos os últimos grupos de paiaiases sob administração do dono das terras pertencentes ao grande sesmeiro, criador de gado e enigmático João Peixoto Viegas. ${ }^{48} \mathrm{Na}$ mesma época, diversas foram as investidas para livrar os sertões dos mocambos que se espalhavam pelas regiões mais distantes ou de difícil acesso. ${ }^{49}$

No final do século XVII e sobretudo no início do século XVIII, o processo de interiorização se intensificou após o anúncio da descoberta de ouro nas Minas de São Paulo, inaugurando o terceiro movimento de ocupação dos sertões. O fluxo de homens almejando tirar a sorte grande com a mineração, garimpo ou comércio de gêneros necessários ao trabalho e alimentação dos novos frequentadores da zona aurífera, provocou um constante fluxo pela região que ligava o Recôncavo Baiano à Vila de Sabará. Caminhos foram abertos, indígenas exterminados ou aldeados, mocambos liquidados para permitir uma travessia relativamente livre por aquelas paragens, sempre passíveis de testemunhar conflitos, acertos de contas e assaltos. Não havia somente uma estrada que ligava a Bahia às regiões de mineração para além do Jequitinhonha. ${ }^{50}$ Eram vários os caminhos, picadas e atalhos passando pelo sertão do rio das Piranhas, sertão dos índios Maracás (reduzidos no início do século XVIII), seguindo pelo Alto sertão e pelo planalto do sertão da Ressaca, dominado pelos índios mongoiós, pataxós e os imborés (botocudos) até pelo menos as décadas de 1730 e $1740 .{ }^{51}$ A região entre os rios de Contas e Pardo foi conquistada pela bandeira do mestre de campo João da Silva Guimarães, tendo como figura destacada o capitão-mor João Gonçalves da Costa, ${ }^{52}$ seguindo no encalço das trilhas percorridas pelo sertanista, coronel e superintendente Pedro Leolino Mariz, responsável por

47. Juliana Brainer Barroso Neves. op. cit.

48. DH. "Registo da Provisão por que se concedeu a João Peixoto Viegas a Administração do Gentio Payayá " vol 25, p. 397. Utilizado o qualificativo enigmático para descrever João Peixoto Viega na medida em que a origem de sua fortuna nunca foi muito bem explicada pela historiografia especializada, apesar de diversos esforços no sentido de traçar a história deste homem, possivelmente cristão-novo que conseguiu ocupar importantes cargos administrativos, receber enorme quantidade de terras, além de acessar os círculos da nobreza da terra (composto inclusive por membros da Inquisição) através do casamento.

49. Juliana Brainer Barroso Neves fez um belo quadro contendo referências feitas à expedições destinadas ao extermínio dos mocambos dos sertões. op. cit. p. 85-86.

50. Raphael Freitas Santos. Minas com Babia: mercados e negócios em um circuito mercantil setecentista. UFF, Niterói, 2013. p. 64 e segs.

51. Sobre o trânsito naquela região, ver: Isnara Pereira Ivo. Homens de caminho: trânsito, comércio e cores nos sertões da América Portuguesa - século XVIII. UFMG, Belo Horizonte, 2009.

52. Maria Aparecida Silva e Sousa. A Conquista do Sertão da Ressaca: povoamento e Ocupação de terra no interior da Babia. Vitória da Conquista, 2001, p. 48; Idelma Aparecida Ferreira Novais. Produção $e$ Comércio na Imperial Vila da Vitória (Babia, 1840-1888). UFBA, Salvador, 2008, p. 18. 
investigar a incidência de pedras e metais preciosos em Rio de Contas, Paramirim, Rãs, até as Minas Novas de Araçuaí. ${ }^{53}$

As descobertas de ouro em Rio de Contas, Jacobina e Caetité também contribuíram para ampliar a vazante do fluxo em direção aos centros mineratórios. Apesar do vestígio de existência de metais na região de Jacobina ser conhecido pelos portugueses desde o início do século XVII, não houve exploração imediata, passando a ser "objeto de preocupações econômicas" somente em fins do período seiscentista, em meio as constantes proibições de exploração das minas existentes na capitania da Bahia. As inúmeras expedições enviadas para reconhecimento e prospecção da área resultaram em um maior fluxo e abertura de caminhos por aquelas bandas desde cedo contando com a nomeação de militares das mais diversas patentes. ${ }^{55}$ Verdadeiros "práticos dos sertões", muitos foram os homens formadores das primeiras expedições que acabaram por ser estabelecer pelas redondezas, montando fazendas já existentes nos sertões próximos ao Rio de Contas e Jacobina quando foi autorizada à exploração a partir da Carta Régia de 5 de agosto de 1720.56

A busca e exploração do salitre também auxiliou na aceleração do processo de devassamento dos sertões. O minério era utilizado para a fabricação da pólvora e despertava grande cobiça e ansiedade nas autoridades régias, visto o produto ser importado do Oriente para sanar as necessidades das tropas. A experiência mais bem documentada foi a busca e identificação das minas de Salitre localizadas em Monte Alto, na região do Rio de Contas, mas ao que tudo indica, não chegou a existir uma ampla exploração do minério devido à baixa qualidade. ${ }^{57}$

Evidente que as áreas mineradoras existentes nos sertões baianos possuem uma particularidade quando comparadas com as demais regiões estudadas. Diferente das fazendas de gado caracterizadas pela ocupação extensiva e pela baixa densidade demográfica, as zonas auríferas tem por definição um perfil possibilitador da formação de grandes aglomerações populacionais. Isto se deve muito ao fato do sistema de distribuição das catas e à grande quantidade de trabalhadores necessários para exploração intensiva da área. Fora o trabalho direto exigido por um regime exaustivo de exploração humana e natural, as regiões mineradoras atraíam uma quantidade significativa de homens e mulheres dedicados a prestar serviços e abastecer as áreas de extração. ${ }^{58}$ Rio de Contas e Jacobina foram testemunhas deste processo.

53. Maria Aparecida Silva de Sousa. op. cit. p. 31.

${ }^{54}$. Albertina Lima Vasconcelos. Ouro: conquistas, tensões, poder, mineração e escravidão- Babia do século XVIII. Unicamp, Campinas, 1998, p. 62.

55. Idem.

56. Idem, p. 75.

57. AHU. "Ofício do Vice-rei Conde dos Arcos para o Desembargador João Pedro Henriques da Silva, em que lhe transmite as instruções necessárias para o desempenho da sua comissão à Serra dos Montes Altos, a que outros documentos se referem." Bahia, 5 de maio de 1758. c. 19, doc. 3474.

58. Sobre as regiões de mineração da capitania da Bahia, ver: Albertina Lima Vasconcelos. op. cit. ; Kátia Lorena Novais Almeida. Escravos e libertos nas Minas do Rio de Contas - Babia, século XVIII. Salvador, 2012. 
Formaram grandes povoações, tornando-se rapidamente vilas movimentadas e cabeças de comarca, com grande influência nas paragens vizinhas. Mesmo com o fim da mineração nas duas vilas, sua importância continuou perceptível, sendo consideradas regiões promissoras na criação do gado vaccum.

A última e quarta região ocupada foram os sertões próximos aos rios Pardo, Verde Grande e São Mateus, pertencentes em grande medida às capitanias de Ilhéus e Porto Seguro, genericamente identificados por Maria Hilda Paraíso como "sertões do Leste". ${ }^{59}$ Muitas das tribos ali estabelecidas foram parar naquelas bandas por deslocamento forçado após sobreviverem a combates e devastamento de suas terras nas regiões ocupadas pelos sertanistas e sesmeiros. Lá estava boa parte dos índios aimorés. ${ }^{60}$ Contraditoriamente entendida como zona tampão, a região tinha por característica simultânea a proximidade estratégica em relação às Minas Gerais ao mesmo tempo em que atraía poucos investimentos. Contou com esparsos pontos de ocupação efetiva até o final do século XVIII devido à resistência indígena. ${ }^{61} \mathrm{~A}$ abertura de estradas e a maior ocupação das partes interioranas próximas ao sertão da Ressaca e à margem direita do Rio de Contas, após os sucessivos massacres, promoveram uma maior integração da região recém-conquistada com o restante da capitania da Bahia, à qual estas partes haviam sido recentemente anexadas. ${ }^{62}$

\section{Divisão dos sertões}

O abastecimento das Minas Gerais foi um problema enfrentado pelas autoridades régias nas primeiras década do século XVIII, gerando muitos conflitos e instabilidade em paragens tão distantes dos centros de decisão do poder colonial. É necessário lembrar que um dos motivos de eclosão da guerra dos Emboadas no ano de 1708 foi a tentativa do frei português Francisco de Meneses de monopolizar o comércio de carne na região. ${ }^{63}$ Manuel Nunes Viana, famoso pelos desmandos cometidos nos sertões, causou tumultos quando decidiu que somente o gado vindo de suas fazendas seria cortado e consumido por aquelas bandas. A situação só começou a mudar com a nomeação de Antônio de Albuquerque Coelho e Carvalho, então governador do Rio de Janeiro para assumir a administração da nova capitania de São Paulo e Minas do Ouro criada no ano de 1710. Os habitantes logo perceberam que era de competência do novo governador gerir assuntos condizentes ao

\footnotetext{
59. Maria Hilda Baqueiro Paraíso. O tempo da dor e do trabalbo: a conquista indígena nos sertões do leste. USP, São Paulo, 1998

60. Idem

61. Caio Figueiredo Fernandes Adan. Colonial Comarca de Ilhéus: soberania e territorialidade na América Portuguesa (1763-1808). Salvador, 2009; Marcelo Henrique Dias. Economia, sociedade e paisagens da capitania e comarca Ilhéus no período colonial. UFF, Niterói, 2007.

62. Caio Figueiredo Fernandes Adan. op. cit., p. 138.

63. Flávio Marcus Silva. Subsistência e poder: A politica do abastecimento alimentar nas Minas setecentistas . UFMG, Belo Horizonte, 2002, p. 41. Ver também relato de Bento Fernandes Furtado sobre os primeiros descobertos de ouro (meados de 1750). Códice Costa Matoso. p. 192-193.
} 
abastecimento e controlar os abusos da elite local, sendo a ele direcionadas todas as reclamações dos desmandos cometidos por grandes fazendeiros e potentados que não pestanejavam em aproveitar a grande procura pelo gado em pé para cobrar preços extorsivos pelo produto. ${ }^{64}$

Desde muito cedo o movimento migratório para as Minas Gerais partindo da capitania da Bahia - tornou-se um problema para as autoridades régias. Tentaram de todos os modos regular a migração de homens e mulheres para a região, mas principalmente, concentraram esforços para pensar nos meios de coibir o fluxo de mercadorias e abertura de novas estradas facilitadoras do contrabando do ouro escoado pelo porto de Salvador, de acordo com a Carta Régia de 07 de fevereiro de 1701. Todavia, por mais que houvesse um intuito de provocar a diminuição do fluxo de pessoas pelos caminhos da Capitania da Bahia em direção à vila de Sabará e arredores, era necessário abastecer de víveres e mercadorias básicas as áreas auríferas, especialmente nas primeiras décadas, quando ainda não havia se consolidado uma produção local voltada para o suprimento do exército de mineradores livres e escravos necessários para os trabalhos de extração do ouro. ${ }^{65}$

Mesmo que o abastecimento das Minas via Bahia fosse muito mais eficiente e até racional (devido a maior proximidade e facilidade de acesso a regiões de produção de gêneros alimentícios mais consolidadas), a opção por proibir as estradas que ligavam Minas com Bahia foi uma decisão tomada em meio a disputas políticas, mas também sob o argumento prático da dificuldade em vigiar os inúmeros caminhos e possíveis atalhos abertos para facilitar o contrabando de ouro em um espaço tão vasto. ${ }^{66}$

Apesar da proibição ser muito mais formal do que prática, o fato é que os caminhos passaram a contar com um aparato de segurança capaz de coibir a ação de contrabandistas e teimosos comboieiros que cismavam em passar pelos caminhos proibidos. A substituição dos caminhos da Bahia pela Estrada Real que ligava as regiões mineradoras ao porto do Rio de Janeiro só se consolidou na década de $1730 .{ }^{67}$ Certamente as perdas justificavam os riscos, assim como em toda atividade ilegal. ${ }^{68}$

Para além da proibição formal, foi criado todo um esquema de denúncia para facilitar a prisão dos comerciantes que continuavam a utilizar os caminhos da Bahia. A apreensão de mercadorias e escravos, registrados pelos

\footnotetext{
64. Idem.

65. Há um debate historiográfico quanto ao caráter da economia mineira no século XVIII. Angelo Alves Carrara. Minas e Currais: Produção rural e Mercado Interno de Minas Gerais (1674-1807). Juiz de Fora, 2007.p. 13-75.

66. Sobre a maior comodidade dos caminhos das boiadas vindas da Bahia, ver: Minas com Bahia. Angelo Alves Carrara. op. cit. , p. 124 e segs.

67. Idem.

68. Sobre o contrabando, ver: Paulo Cavalcante de Oliveira Junior. Negócios de Trapaça: caminhos e descaminhos na América Portuguesa (1700-1750). USP, São Paulo, 2002.
} 
autos de tomadia, foi uma política deliberada para reprimir os contraventores. ${ }^{69}$ Funcionava com uma espécie de delação premiada em que o responsável por denunciar a entrada dos comboios pela região da vila de Sabará, considerada a porta das Minas Gerais, receberia como prêmio parte da carga apreendida, resultando em uma verdadeira caça aos comerciantes, facilitando muito os abusos por parte dos oficiais responsáveis pela operação. Em 1724, alguns deles passaram a ser investigados por cometer excessos nos sertões, além de deixarem de declarar parte da carga confiscada. ${ }^{70}$

A única exceção para a política de caminho único da Estrada Real com destino ao porto do Rio de Janeiro e a concomitante proibição do transporte de mercadorias da capitania da Bahia em direção às Minas Gerais foi a condução do gado em pé. ${ }^{11}$ Alguns fatores beneficiaram a decisão das autoridades responsáveis pelo rearranjo dos caminhos e pelo abastecimento da região mineradora durante as primeiras décadas. Primeiramente, contou muito a proliferação de fazendas de gado pelos sertões baianos próximos ao rio de São Francisco, não muito distantes do sertão de Jequitinhonha ainda pertencente à capitania da Bahia. A paisagem relativamente plana e com acidentes geográficos facilmente transponíveis ajudava a condução das boiadas não muito afeitas a terrenos montanhosos, como era o caso da região ao sul da Serra da Mantiqueira, onde inclusive ainda não havia uma produção pecuária nos moldes dos sertões baianos. ${ }^{72}$ Não foi por falta de tentativa das autoridades régias que as partes mais ao sul não se tornaram abastecedoras de gado já no início do século XVIII. Desesperado por causa das encrencas causadas por Manuel Nunes Viana - após ter sido impedido de participar da arrematação dos contratos de carne e proibir ( como represália) que entrasse boiadas pelas suas fazendas, onde costumavam engordar antes de seguir para abate - , o Conde de Assumar chegou a averiguar a viabilidade do sul do Brasil enviar cerca de 20.000 cabeças de gado para a comarca do Rio das Velhas em 1718. Evidente que tal demanda era impossível de ser atendida na ocasião, restando somente a opção do gado em pé vindo da Bahia. ${ }^{73}$

Todavia, o que pareceu (em um primeiro momento) uma solução para abastecer as regiões mineradoras e garantir a felicidade dos fazendeiros que viam no novo mercado consumidor uma possibilidade de altos lucros, mostrou-se um problema para a primeira capital da América Portuguesa e seus

69. Os autos de tomadia localizados na Biblioteca Nacional correspondem principalmente ao período em o confisco foi regularmente feito, ou seja, entre os anos 1704 a 1711. Angelo Carrara, op. cit., p. 125.

70. AHU. Documentos Avulsos. c.19 d. 1709. Carta do desembargador da Relação da Bahia João Veríssimo da S. Torres Cordeiro ao rei sobre a devassa que se lhe mandou tirar dos oficiais da Fazenda responsáveis pela arrecadação das tomadias das Minas.” 16 de junho de 1724.

71. DI. "Carta de D. Álvaro da Silveira de Albuquerque ao mestre de campo Domingos da Silva Bueno ordenando-lhe que prendesse vários transgressores da lei proibitiva de comunicações entre as Minas e a Bahia, pelo, sertão, avisando-o de que só permitisse por ali a entrada do gado vaccum e reiterando-lhe a recomendação para que expelisse das Minas os soldados fugidos de lá. Rio de Janeiro, 13 de março de 1703. vol. 51, p. 157.

72. Segundo carta de 1702, as embarcações vindas do Rio de Janeiro eram abastecidas no porto de Salvador. AMS. 27 de setembro de 1702, p. 119, vol. 7.

73. Flávio Marcus Silva. op. cit., p. 96. 
habitantes. Com a concorrência das Minas Gerais iniciou-se uma série de reclamações e descontentamentos referentes à falta de carne na praça de Salvador. Em todas as queixas o motivo da carestia era unânime: a ida de boiadas para as regiões mineradoras por preferência dos criadores que viam lá uma saída melhor para o seu produto. ${ }^{74}$

Foi necessário a intervenção do poder público para que a falta de carne fresca não se tornasse motivo de revolta e tumultos na capital. Em meio a muitos debates, surgiu uma proposta apresentada em 1716. Elaborada pelos oficiais da Câmara de Salvador, enviada ao rei com detalhadas justificativas, a ideia era relativamente simples: dividir os sertões em duas grandes áreas produtoras e abastecedoras dos distintos mercados consumidores. A divisão proposta era de que o gado vaccum criado na altura do rio São Francisco para a parte da serra do Pimentel ${ }^{75}$ em direção às Minas Gerais fosse encaminhado para as regiões auríferas. A serra fazia fronteira com a propriedade do desembargador José de Sá, localizada nas terras observadas por Antonio da Silva Pimentel, genro de Antonio Guedes de Brito $^{76}$. Destas terras até os sertões de baixo e sertões do Piauí, as boiadas deviam ser encaminhadas para a cidade da Bahia de Todos os Santos no sentido de remediar a população e compor a matalotagem das frotas e embarcações da Costa da Mina e "outras muitas que entram neste porto". A povoação de Jacobina também deveria ser abastecida com as reses produzidas naquelas bandas dos sertões baianos. ${ }^{77}$

Vale ressaltar que a decisão da Câmara Municipal de Salvador teve como pano de fundo questões políticas evidentes, admitindo como pressuposto básico que não há dissociação entre política e economia. ${ }^{78}$ Como será demonstrado no próximo capítulo, toda a carne comercializada na cidade da Bahia de Todos os Santos era controlada pela Câmara Municipal de Salvador. $\mathrm{Na}$ medida em que a Câmara era a grande instituição responsável por regular o abastecimento da cidade e era da renda dos talhos (renda vinculada ao direito de cortar a carne verde nos açougues públicos) que auferia a maior parte dos seus ganhos, parece evidente as preocupações e insistência dos vereadores em atrair para a capital a maior parte possível de gado disponível. No entanto, para os produtores da região mais ao sul da capitania da Bahia mostrava-se muito mais interessante e lucrativo (pensando especialmente nos grandes fazendeiros, cuja produção era majoritariamente voltada para o mercado)

\footnotetext{
74. DH. "Carta que se escreveu ao Capitão-mor Manuel Nunes Viana ". vol. 70, 20 de setembro de 1715. p. 262; DH. "Carta para o Conde de Assumar, Governador das Minas" 2 de abril de 1719. vol. 71, p. 57; $A M S$. Cartas do Senado (1710-1730)"Registro da carta escrita a SM sobre os gados do sertão."14 de janeiro de 1719, vol. 6. p. 91.

75. Serra do Pimentel ficava possivelmente na extensa sesmaria de Antonio da Silva Pimentel. Segundo termo de vereação de 1703 estava sempre pela cidade da Bahia e muitas das vezes que fazia-se necessário a representação dos criadores de gado para tomar resoluções que diziam respeito aos interesses da categoria, era um das pessoas consultadas ao lado de Leonor Pereira Marinho e Domingos Afonso Sertão, por serem "senhores da maior parte do sertão". AMS "Termo de vereação" 1 de setembro de 1703 , p. 173. vol. 7.

76. Marcio Roberto Alves dos Santos. op. cit, p. 195.

77. AMS. "Registro da carta escrita a SM de sobre a divisão dos gados do sertão." 28 de julho de 1716. vol. 6. Cartas do Senado (1710-1730) p. 63.

78. Renata Rente, op. cit. p. 8 e segs.
} 
deslocar suas boiadas e boiadeiros para as Minas Gerais. Seria impossível às autoridades proibir totalmente a condução de rebanhos para as regiões mineradoras, além de provocar o descontentamento de muitos homens de negócio, criadores influentes, quando não eram eles mesmos as autoridades régias. ${ }^{79}$ Merece destaque o fato da família do mestre de campo Antonio Guedes de Brito (vereador da Câmara Municipal de Salvador, diga-se de passagem) manter sob controle (através de seus administradores e procuradores) boa parte dos sertões baianos com ocupação direcionada às Minas Gerais, partindo sobretudo do rio São Francisco. ${ }^{80}$

Permitir o fluxo livre de gado para as zonas auríferas significava que a cobrança seria feita então em território de mineração, principalmente na vila de Sabará, considerada a "porta das Minas Gerais", fazendo não só com que diminuísse a arrecadação de Salvador como também aumentasse as competências e funções atribuídas aos responsáveis pelos registros das mercadorias que entravam nas Minas, ou seja, os superintendentes e contratadores estabelecidos nas Gerais. Não que a proposta de divisão dos sertões baianos fosse de total agrado e conveniência para os funcionários e administradores da cidade de Salvador, mas de todos os males este era o menor. Ninguém correria o risco de fazer a população mineira sofrer com carestia de carne, incentivando (indiretamente) ainda mais o contrabando através de proibições totais de fluxo das boiadas e trazendo em descontento os potentados e grande produtores de gado com influência inquestionável nas decisões da Câmara, quando não eram eles mesmos os vereadores. ${ }^{81}$ Além disso, talvez fosse razoável pensar que a divisão significava também um limite para a quantidade de gado encaminhado para as Minas. Tornando-se proibido o encaminhamento de reses produzidas nos sertões do rio São Francisco próximo à Juazeiro e outras regiões de criação mais consolidada e com maior produção que as recentes fazendas estabelecidas nos sertões do Jequitinhonha e no Alto Sertão, garantia-se que a maior parte da produção dos sertões baianos das primeiras décadas do século XVIII continuasse sendo encaminhada para Salvador.

Não se sabe ao certo se a proposta de divisão dos sertões escrita em 1716, tendo como ponto de referência a serra do Pimentel, foi prontamente posta em prática; mas é possível observar nos anos seguintes e até 1789 que as boiadas sertanejas encaminhadas até a feira de Capuame e direcionadas à Salvador tinham como pontos de origem os sertões cujos oficiais da Câmara

79. Vários são os historiadores que acentuam a importância econômica e política dos criadores de gado em contexto colonial. Ver Stuart Schwartz. Burocracia e sociedade no Brasil colonial: a suprema corte na Babia e seus juizes (1609-1751). São Paulo, 1979.

80. Erivaldo Fagundes Neves. op. cit.

81. Dentre os vários fazendeiros e sertanistas que já foram vereadores em Salvador, merece destaque Lopo de Albuquerque da Camara, envolvido inclusive com a busca de minerais. "Termo de vereação e de novo vereador por eleição digo alvará do Desembargo do Paço” 24 de setembro de 1698.p. 361. Ver nota 12, p. 216 de Antonil com anotações de Mansuir. O grande sesmeiro João Peixoto Viegas foi eleito em 1686 o Juiz Ordinário, depois de já ter exercido o ofício de provedor-mor. Ver: Juan Lopes Sierra; Stuart Schwartz; Alcyr Pécora. As excelências do governador: o panegírico fúnebre a D. Afonso Furtado (Babia, 1676). São Paulo, 2002, p. 309. AMS. 16 de fevereiro de 1686. p. 48, vol. 6; Antonio da Rocha Pitta e Coronel Pedro Barbosa Leal eleitos vereadores em 1696. AMS. 4 de fevereiro de 1696, p. 306. 
Municipal haviam delimitado para abastecer a capital da Bahia na proposta de 1716. Aqui cabe somente duas observações, por ora: ou a proposta enviada ao rei pelos oficiais da Câmara de Salvador foi prontamente acatada e obedecida por décadas a fio ou a proposta sugeria uma divisão que já tinha operabilidade no campo prático, visto os sertões mais ao sul já serem majoritariamente destinados a produzir para abastecer Minas Gerais enquanto os sertões mais ao norte tinham uma ligação mais consolidada com a capital da América Portuguesa devido ao seu histórico de formação.

Esta hipótese ganha sentido também quando reparamos que há uma certa similaridade entre a divisão proposta pelos funcionários da Câmara de Salvador em 1716 e o primeiro movimento de ocupação e expansão das fronteiras sertanejas descritas no início deste capítulo. Tal coincidência possivelmente está relacionada a vários fatores a partir de agora elencados.

Mesmo que as duas regiões não fossem totalmente ocupadas pelos dois grandes potentados pertencentes respectivamente a família de Garcia D'Ávila e aos descendentes de Guedes de Brito, havia uma quase total divisão dos sertões baianos em duas áreas de influência devido às grandes sesmarias entregues aos primeiros membros de cada família por serem funcionários régios no século XVII. Mesmo que as terras fossem ocupadas somente a longo prazo, que as doações tivessem sido feitas tendo por objeto doado uma região que não conheciam efetivamente, o certo é que as margens do Rio São Francisco na altura de Xique-Xique em direção ao Rio Jequitinhonha pertencia majoritariamente aos membros da futura casa da Ponte, enquanto do rio Pojuca ao São Francisco até o Piauí pertencia largamente a Casa da Torre.

Os sertanistas responsáveis pela efetivação do primeiro movimento de ocupação interiorana em direção ao rio São Francisco tinham uma ligação visceral com a praça de Salvador, não necessariamente compartilhada por outros sertanistas vinculados, por exemplo, com o segundo movimento partindo das vilas do Recôncavo. Muitos dos sertanistas que foram nomeados e cumpriram a tarefa de expandir os domínios portugueses através da guerra dos bárbaros possuíam ligação com a elite açucareira do Recôncavo Baiano e abriram depois fazendas de gado nas sesmarias adquiridas no interior. Certamente estas unidades dedicadas à criação do gado vaccum deviam encaminhar a produção das fazendas para os engenhos e população das vilas de Cachoeira, Santo Amaro, Camamu, Cairu e Boipeba, mais próximas daquelas em vários sentidos. Fortalece esta ideia o fato de haver vestígios do controle exercido por cada uma das Câmaras das vilas do Recôncavo sobre o comércio da carne verde necessária ao abastecimento das unidades produtivas e funcionários. ${ }^{82}$ Depois de 1701 foi expedida uma sequência de ordens

82. DH. "Carta para os oficiais da Câmara de Cachoeira, sobre os atravessadores dos gados" 22 de julho de 1713 , vol. 43, p. 140; DH. "Ordem que se remeteu ao Juiz Ordinário da Vila da Cachoeira, para ir tirar devassa do caso que representaram Antônio da Rocha, e João Vieira da Costa moradores no sertão da Grugaia " 30 de outubro de 1717. vol. 54, p. 274; DH. "Ordem para os Oficiais da Câmara da Vila de Jaguaribe sobre o preço por que se corta a carne " 7 de março de 1719. vol. 55, p. 205; DH. "Carta que se escreveu aos oficiais da câmara da vila da Cachoeira esôbre o povo de Jaguaripe não pôr em maior preço o gado que se cortar no seu açougue senão pelo preço que os ditos oficiais da Câmara da vila da Cachoeira puserem na sua ordem citada, está registada no livro delas a 
impedindo a criação de gado nas regiões próximas às fazendas dedicadas ao cultivo de gêneros agrícolas, tais como a mandioca. ${ }^{83}$ Levando em consideração o fato da região estar totalmente tomada por roças de mandioca, tabaco e cana, certamente todo o gado necessário para alimentação, força motriz e transporte vinha das fazendas sertanejas cada vez mais distantes, próximas aos rios Paraguaçu e Contas, depois da insistente decisão de impedir os moradores de criarem gado nas vilas próximas ao litoral. ${ }^{84}$

A única exceção é o caso da ocupação dos sertões de Itapororocas por João Peixoto Viegas. Mesmo estando vinculado a um movimento de interiorização mais próximo cronologicamente e contextualmente àquele iniciado pelos senhores das vilas do recôncavo, o grande sesmeiro teve toda sua trajetória vinculada à cidade de Salvador. As terras nas quais deitou extensas fazendas de gado - na região intermediária entre as partes mais interioranas ao rio Paraguaçu e os sertões de dentro - também tinham por destino final abastecer a primeira capital da América Portuguesa. Mesmo que a freguesia de São José das Itapororocas pertencesse à comarca de Cachoeira, ${ }^{85}$, a proximidade com a estrada das boiadas foi um fator a mais para unir as terras do sesmeiro João Peixoto Viegas à Salvador. Interessante notar que dentre os vários sesmeiros e sertanistas do século XVII, o suposto cristãonovo figura como um dos únicos que não possuía patente militar. Sua ascensão meteórica foi marcada pelo ofício de provedor-mor, que era um cargo de alta confiança, pelo casamento com a filha de um abastado senhor de engenho e ex-vereador da Câmara Municipal, pela união de sua família com a dos herdeiros de Bernardo Ravasco através do casamento de seu filho com Ângela Bezerra ${ }^{86}$ tornando-se ainda um enigma para a historiografia como acendeu tão rápido na hierarquia social da colônia. Sabendo do alto retorno econômico que o contrabando e o descaminho traz, é possível conjecturar que o sesmeiro estivesse envolvido com alguma atividade ilícita. Resta saber se a hipótese se confirma e qual era a sua participação na reprodução da sociedade colonial.

Os sertões separados para abastecer preferencialmente as regiões das Minas Gerais na proposta de 1716 eram aqueles ocupados e desembaraçados da presença de indígenas em momento concomitante à própria descoberta das zonas de extração. Salvo alguns caminhos abertos e poucas fazendas

folhas 102" ,7 de março de 1719. vol. 73, p. 35; DH. "Para os oficiais da Câmara da Vila de Jaguaripe" 26 de junho de 1719. vol. 73, p. 129, entre outros.

83. Caio Prado Junior. Formação do Brasil Contemporâneo. São Paulo, 1986, p. 188.

84. DH "Carta para os oficiais da Câmara da Vila de Boipeba sobre pedirem lhes concedam o poderem criar gados no termo da mesma Vila" 24 de novembro de 1704. vol. 40, p. 251; DH. "Carta para o Sargento-maior da Vila de Boipeba, sobre mandar notificar aos Padres Vigário e Coadjutor, e aos mais moradores da mesma Vila que tiverem gados os retirem para parte onde não prejudiquem a lavoura." 30 de janeiro de 1705. vol.40, p. 307; DH. "Carta para os Oficiais da Câmara da Vila da Cachoeira, sobre a execução do bando no que toca aos gados, e que nos lugares do Capoeyrosú, Pinguella, Varse e Freguezia de São Pedro não haja mais plantas que as de mandioca " 1 de julho de 1705 , vol. 41 , p. 75.

85. Rollie Poppino. Feira de Santana, Salvador, 1969, p. 19.

86. Juan Lopes Sierra; Stuart Schwartz; Alcyr Pécora. As excelências do governador: o panegírico fúnebre a $D$. Afonso Furtado (Babia, 1676). São Paulo, 2002, p. 309-10 
pertencentes aos primeiros sertanistas, a região ao sul do rio de Contas só foi devidamente apropriada e convertida maciçamente em área produtiva no decorrer do século XVIII. ${ }^{87}$ Fora o movimento de expansão da pecuária margeando o alto rio São Francisco, algumas fazendas esparsas pertencentes aos Guedes de Brito e mais meia dúzia de sertanistas, o fator decisivo para ocupar os sertões em direção às Minas Gerais foi o movimento migratório em direção às zonas de extração aurífera. ${ }^{88}$

Já nas primeiras décadas do século XVIII tornou-se perceptível o fluxo do gado para a comarca do Rio das Velhas vindo de fazendas próxima aos sertões do Rio de Contas, Alto Sertão e alto rio São Francisco. Casos concretos são os relatos sobre as boiadas pertencentes ao potentado Manuel Nunes Viana, administrador das fazendas dos Guedes de Brito, encaminhados à Vila de Sabará. ${ }^{89}$ Certamente uma análise mais detalhada dos autos de tomadia e registro de entrada das boiadas encaminhada para as Gerais poderá reforçar quais eram os sertões de maior proveniência do gado.

\section{Sertões abastecedores de Capuame}

Através dos "Livros de Registro de Entrada de Gado" da feira de Capuame, foi possível mapear todas as áreas produtoras e abastecedoras da cidade de Salvador. Evidente que o recorte limitado aos anos de 1784-1789 não permite uma análise seriada que possa mostrar talvez as flutuações no abastecimento do gênero, as mudanças na recorrência de algumas regiões em detrimento de outras, a alternância de fluxos da mercadoria gado e outras informações só possivelmente observáveis caso estivéssemos diante de uma série documental mais abrangente. No entanto, por mais que sejam poucos os anos mapeados, já é possível tirar algumas conclusões e montarmos um quadro sobre algumas características gerais do abastecimento do gado em pé.

Particularmente o "Livro de Registro de Entrada de Gado" de 17841789 possui uma organização mais metódica e de fácil sistematização dos dados anotados pelo escrivão Camilo..$^{90}$ De um capricho e didatismo exemplar, em todos os dias de feira foram anotados esquematicamente o nome dos criadores ou condutores do gado, o sertão de onde o rebanho era originário e o número de reses de cada boiada. ${ }^{91}$

\footnotetext{
87. Idelma Novais, op. cit., Maria Aparecida Silva de Sousa, op. cit.; Isnara Pereira Ivo. op. cit.

88. Aqui é interessante notar que de fato a importância da descoberta do ouro enquanto fator de ocupação territorial mostra-se relevante para as regiões próximas ao Alto Sertão e não necessariamente para a maior parte das partes ocupadas pelo primeiro movimento de territorialização aqui descrito.

89. Marcus Flávio Silva. op. cit.

90. Não foi possível compreender qual era o nome completo do escrivão responsável pelo primeiro "Livro de Registro de gado" da feira de Capuame (1784-1789).

91. Interessante reparar que o livro é contemporâneo à proliferação de escolas de contabilidade na América Portuguesa e simultâneo a uma mudança na sistematização dos dados coletados para uma gerência mais ilustrada das contas públicas e também privadas.
} 
Para facilitar a pesquisa foi feito um Banco de Dados com todas as informações constantes no documento. Foram no total 1945 entradas de gado durante os cinco anos de abrangência da fonte. Destas entradas, foi possível calcular a aparição de sessenta e um sertões diferentes. Ou seja, o local de origem das boiadas era sempre anotado tendo primeiramente o substantivo "sertão" seguido pelo qualificativo mais específico quanto a localidade. Em ordem alfabética, os sertões mencionados nos "Livros de Registro de Entrada de Gado" foram:

Sertão do Caatingas, Cafucá, Calindé (ou Canindé), Canabraba, Caraíbas, Carioca, Contendas, Cupança, Curimatâ, Curuçá, Goaribas (ou Guaribas), Gruguea, Guinguinge, Inhambupe, Itabaiana, Itaim, Itapicuru, Jacobina, Jacobina Nova, Jacorissy (ou Jacurissê), Jaguaribe (ou Jaguaripe), Japaratuba, Jeremoabo (ou Geremuabo), Lagarto, Inhamuns (ou Manhuns, Hiamuns), Ituassú, Massacará, Monte Santo, Morro do Chapéu, Mundo Novo, Natuba, Pajahú (ou Pajeú), Pancaroy, Paramirim, Parnaguá (ou Parauhá, Parnahuá), Parnauba, Patamute, Piauí, Porció Ponto, Porto da Folha, Queimadas, Quiricó, Riacho da Brigida, Rio Abaixo (ou Rio de Baixo), Rio do Peixe, Rio Grande, Rio Real, Rio São Francisco, Rodelas, Saco do Moura, Sento Sé, Serra Vermelha, Serrinha, Sifra, Tacarissé, Tarâ, Tocós, Tucano, Urubu, Urubu Grande, Vaza Barril.

Tirando as boiadas resgatadas ou confiscadas por militares nos caminhos com a descrição "para suprir a Cidade" em épocas de carestia e as informações ilegíveis ou que não possuíam referência do local de origem das reses, foi possível levantar 1409 localidades especificadas no "Livro de Registro de Entrada de Gado".

É inegável a preponderância na feira de Capuame do gado com procedência do Piauí. Se for levado em consideração que o sertão do Itaim, Canindé, Riacho de Brigida faziam parte da capitania do Piauí, então chegamos a um total de 313 boiadas enviadas. A supremacia dos bovinos de origens piauiense tem motivos certamente históricos. $O$ primeiro deles está relacionado ao próprio movimento de ocupação e apropriação das terras do sul do Piauí por iniciativa de sertanistas vindos da capitania da Bahia. ${ }^{92}$ Os maiores exemplos deste processo foram Domingos Afonso Sertão e a família dos Garcia D'Ávila. Inclusive, é interessante destacar que o Piauí consta como a única capitania cujo movimento de ocupação partiu do interior sentido litoral e não o contrário.

92. Sobre as fazendas de gado da capitania do Piauí, ver: Luiz Mott. Piauí Colonial: população, economia e sociedade. Teresina, 1985. 
QUADRO 3: Origem do gado da Feira de Capuame (1784-1789)

\begin{tabular}{|c|c|c|}
\hline REFERÊNCIA & SERTÃO & OCORRÊNCIA \\
\hline 1 & Rio São Francisco & 237 \\
\hline 2 & Piauí & 193 \\
\hline 3 & Tucano & 190 \\
\hline 4 & Morro do Chapéu & 88 \\
\hline 5 & Jacobina & 86 \\
\hline 6 & Itapicuru & 78 \\
\hline 7 & Vaza Barril & 65 \\
\hline 8 & Itaim & 55 \\
\hline 9 & Canindé & 50 \\
\hline 10 & Curussá & 42 \\
\hline 11 & Jeremoabo & 35 \\
\hline 12 & Pajeú & 22 \\
\hline 13 & Lagarto & 18 \\
\hline 14 & Jacorissy & 14 \\
\hline 15 & Rio Real & 14 \\
\hline 16 & Sento Sé & 14 \\
\hline 17 & Administração Real (Piauî) & 12 \\
\hline 18 & Massacará & 12 \\
\hline 19 & Riacho da Brigida & 11 \\
\hline 20 & Inhamuns & 10 \\
\hline 21 & Paranaguá & 10 \\
\hline 22 & Natuba & 9 \\
\hline 23 & Patamute & 9 \\
\hline 24 & Porto da Folha & 9 \\
\hline 25 & Caatingas & 8 \\
\hline 26 & Cafucá & 8 \\
\hline 27 & Tocós & 8 \\
\hline 28 & Itabaiana & 7 \\
\hline 29 & Gruguéias & 6 \\
\hline 30 & Jaguaribe & 6 \\
\hline 31 & Monte Santo & 6 \\
\hline 32 & Rodelas & 6 \\
\hline 33 & Guaribas & 5 \\
\hline 34 & Guinguinge & 5 \\
\hline 35 & Quiricó & 5 \\
\hline 36 & Rio de Baixo & 5 \\
\hline
\end{tabular}




\begin{tabular}{|c|c|c|}
\hline 37 & Rio do Peixe & 4 \\
\hline 38 & Jacobina Nova & 3 \\
\hline 39 & Mundo Novo & 3 \\
\hline 40 & Queimadas & 3 \\
\hline 41 & Tacarissê & 3 \\
\hline 42 & Caraíbas & 2 \\
\hline 43 & Pancarahy & 2 \\
\hline 44 & Parnaúba & 2 \\
\hline 45 & Saco do Moura & 2 \\
\hline 46 & Canabraba & 1 \\
\hline 47 & Carioca & 1 \\
\hline 48 & Contendas & 1 \\
\hline 49 & Cupança & 1 \\
\hline 50 & Curimatâ & 1 \\
\hline 51 & Inhambupe & 1 \\
\hline 52 & Ituassu & 1 \\
\hline 53 & Japaratuba & 1 \\
\hline 54 & Paramirim & 1 \\
\hline 55 & Porció Ponto & 1 \\
\hline 56 & Rio Grande & 1 \\
\hline 57 & Serra Vermelha & 1 \\
\hline 58 & Serrinha & 1 \\
\hline 59 & Sifra & 1 \\
\hline 60 & Tarâ & 1 \\
\hline 61 & Urubu & 1 \\
\hline 62 & Urubu Grande & 1 \\
\hline
\end{tabular}

Fonte: AMS. "Livro de Registro de Gado" da feira de Capuame (1784-1789)

Durante muito tempo foi fruto de debate entre as autoridades o destino final do gado produzido nas paragens formadoras dos sertões da capitania do Piauí. Além da proposta de encaminhar as reses para a capital piauiense mas principalmente para o Maranhão ( distante noventa léguas, com quem mantinham comércio no qual as reses eram trocadas por redes, panos de algodão e cuias) ${ }^{93}$ estava em debate manter como centro de atração das

93. "Descrição do Sertão do Piauí remetida ao Ilmo. Revmo. Sr. Frei Francisco de Lima, Bispo de Pernambuco, de autoria do padre Miguel de Carvalho." Transcrito e publicado com atualização da linguagem de época, pelo padre Cláudio Melo. Padre Cláudio Melo. Descrição do Sertão do Piaui comentários e notas do Pe. Cláudio Melo. Teresina: Instituto Histórico e Geográfico Piauiense, 1993, p.16 apud: Luiz Mott. Piaui Colonial: população, economia e sociedade. Teresina, 1985. 
criações a capital da América Portuguesa: a cidade de São Salvador da Bahia de Todos os Santos. ${ }^{94}$

Por motivos políticos, pela influência de grandes fazendeiros ligados à praça de Salvador, mais também por fatores vinculados à maior procura, necessidade de carne verde e consolidação dos caminhos, optou-se por incentivar a ida das criações para uma das principais cidades e portos do hemisfério sul no século XVIII. Esta medida foi respeitada por todo o período setecentista. Quando do confisco das fazendas de gado vaccum dos jesuítas (doada aos religiosos em testamento pelo sertanista Domingos Afonso Sertão), no momento de sua expulsão das possessões portuguesas, toda os bovinos criados nas unidades produtivas passaram a ser propriedade do Fisco Real. Segundo documento de 1790, "Fora o Ministro do estado Francisco Xavier de Mendonça Furtado que propôs ser conveniente praticasse nas faẓendas o mesmo sistema dos jesuitas expulsos, mandando as boiadas a vender-se na Babia." "95 Era obrigatório o encaminhamento de todas as reses diretamente para a feira de Capuame, acompanhadas com uma quantidade significativa de passadores e condutores além de trabalhadores escravos portando todos os documentos sobre o carregamento Real.

As boiadas vindas das propriedades anteriormente pertencentes aos jesuítas aparecem no "Livro de Registro de Entrada de Gado" especificadas com o termo "Gado da Administração Real". Tiveram doze entradas durante os cinco anos de abrangência da documentação analisada. Em 26 de maio de 1784, o condutor Lourenço de Souza Pinto registrou 200 reses; Em 26 de março de 1788 foram 154 reses conduzidas por Martinho da Costa. Na semana seguinte ( 2 de abril de 1788) foi a vez do condutor Manoel Alves com 215 reses; 17 de abril de 1788, Dimiciano de Vasconcelos registrou 170 reses; 14 de maio de 1788 entrou José Fernandes com 206 reses. Na semana seguinte (21 de maio de 1788) Manoel Rodrigues Monção conduziu 190 reses; Na outra quarta-feira (28 de maio de 1788) foi a vez do registro de três boiadas: Antonio José da Rocha com 162 reses; Joaquim Marques com 203 reses e Antonio Ferreira acompanhado de 160 cabeças de gado. Em 18 de junho de 1788 entraram 155 reses da Administração Real do condutor com nome ilegível; 25 de junho de 1788 José Felix da Silva chegou com 186 bovinos e 3 de julho de 1788 registrou Manoel da Silva Estrela a condução de 164 reses.

Interessante reparar que só foi especificado o termo gado da Administração Real para as boiadas vindas em 1784 e 1788. Pelo que consta na documentação das fazendas administradas pelo Fisco Real não houve interrupção no envio das reses. Deve ter acontecido uma falta de especificação mais minuciosa da origem do gado, possivelmente identificado genericamente como vindo do sertão do Piauí. Com certeza a mesma falta de especificação ocorreu no registro de mais boiadas vindas das Fazendas da Administração Real na medida em que o encaminhamento anual era muito mais numeroso do

94. AHU. Piauí. Caixa 4. Maranhão, 4 de setembro de 1784.

95. AHU. Piauí, caixa 7. "Consulta ao Sr. Martinho de Mello e Castro a respeito do que fazer com as boiadas das Fazendas dos Jesuítas" 7 de janeiro de 1790. 
que o anotado nos "Livros de Registro de Entrada de Gado" da feira de Capuame. Em carta do governador interino do Piauí, de 27 de setembro de 1786, é possível constatar que o envio do gado ocorreu normalmente para a feira de Capuame. Naquele ano foram passadas treze boiadas cada qual com 260 bovinos. Daqui também podemos avaliar as perdas por morte das reses nos caminhos. Se a média de reses que chegavam à Capuame era algo em torno de 200 cabeças, pode ser razoável pensar que uma quantidade incrível de bois e vacas ficavam pelos caminhos durante a longa jornada de 300 léguas. Fora as reses usadas para alimentação dos passadores e escravos, outros "bixanos" certamente morriam, atolavam ou ficavam pelos caminhos devido a doenças ou fraqueza para seguir viagem. ${ }^{96}$ As autoridades responsáveis pela condução das boiadas vindas das Fazendas da Administração Real pediam constantemente para que fosse investigado o motivo de tantas perdas e quais deveriam ser as providências cabíveis para diminuir drasticamente as baixas que podiam chegar a quase $50 \%$ do rebanho. Exagero ou não, a mortandade das reses pelos caminhos era bem conhecida dos criadores e condutores setecentistas. No caso do gado vindo das Fazendas da Administração Real, era possível fazer estudos e tomar medidas que impedissem tal prejuízo. Uma das soluções foi deixar parte das reses "estrupiadas" sob o cuidado de alguns procuradores nomeados pelos caminhos. Certamente eram homens de confiança, possivelmente grandes fazendeiros, com quem o gado ficaria temporariamente sob a guarda e cuidado até a recuperação e engorda. ${ }^{97}$

A partir de 1770 há informações sobre as boiadas criadas nas Fazendas da Administração Real. Segundo inventário de 1782, havia nas fazendas um total de 489 escravos, 1.010 cavalos, 1.860 éguas e 50.670 cabeças de gado vaccum. Tudo se avaliava em 179:787\$000. As fazendas eram divididas em Inspeções: Santo Ignácio do Canindé, São João do Piauí e Nossa Senhora do Nazareth. O gado de cada uma das capelas tinha uma marca de ferra específica. Cada uma delas aparecia desenhada na lateral da documentação que os passadores conduziam até Capuame.

96. AHU. Piauí, Caixa 4. 27 setembro 1786.

97. Idem. 
QUADRO 4: Gado das fazendas da Administração Real (Piauí) conduzidos para Capuame / Inspeção: Santo Ignácio do Canindé (1770-1788)

\begin{tabular}{|l|r|r|r|}
\hline ANO & BOIADAS & TOTAL DE RESES & PRODUTO LÍQUIDO \\
\hline 1770 & 3 & 920 & $1: 713 \$ 240$ \\
\hline 1771 & 3 & 943 & $1: 940 \$ 720$ \\
\hline 1773 & 3 & 791 & $1: 341 \$ 700$ \\
\hline 1772 & 3 & 926 & $2: 291 \$ 020$ \\
\hline 1774 & 4 & 1143 & $2: 307 \$ 320$ \\
\hline 1775 & Não saiu boiada & & \\
\hline 1776 & 6 & 1676 & $3: 800 \$ 920$ \\
\hline 1777 & 3 & 916 & $2: 147 \$ 220$ \\
\hline 1778 & 2 & 596 & $1: 383 \$ 280$ \\
\hline 1779 & 3 & 889 & $2: 672 \$ 820$ \\
\hline 1780 & 4 & 1158 & $2: 539 \$ 200$ \\
\hline 1781 & 1 & 306 & $790 \$ 960$ \\
\hline 1782 & 3 & 811 & $2: 979 \$ 620$ \\
\hline 1783 & 3 & 909 & $2: 424 \$ 680$ \\
\hline 1784 & 2 & 627 & $1: 685 \$ 720$ \\
\hline 1785 & 19 & 200 & $554 \$ 800$ \\
\hline 1786 & 6 & 1560 & $5: 663 \$ 540$ \\
\hline 1787 & 1 & 205 & $420 \$ 620$ \\
\hline 1788 & 6 & 1500 & $2: 940 \$ 37$ \\
\hline & & & \\
\hline
\end{tabular}

Fonte: AHU. Piauí, AHU_CL_CU_016, cx.11, d. 646, d. 656, d. 666, d. 669, d. 693, d. 700. 
QUADRO 5: Gado das fazendas da Administração Real (Piauí) conduzidos para Capuame /Inspeção: São João do Piauí (1770-1788)

\begin{tabular}{|c|c|c|c|}
\hline ANO & BOIADAS & TOTAL DE RESES & PRODUTO LÍQUIDO \\
\hline 1770 & 2 & 419 & $529 \$ 740$ \\
\hline 1771 & 2 & 492 & $827 \$ 640$ \\
\hline 1772 & 2 & 505 & $926 \$ 460$ \\
\hline 1773 & 2 & 504 & $895 \$ 720$ \\
\hline 1774 & 2 & 547 & $951 \$ 340$ \\
\hline 1775 & - & - & - \\
\hline 1776 & 2 & 511 & 1:173\$920 \\
\hline 1777 & 1 & 255 & $465 \$ 840$ \\
\hline 1778 & 2 & 497 & $889 \$ 120$ \\
\hline 1779 & - & - & - \\
\hline 1780 & 2 & 569 & $1: 186 \$ 280$ \\
\hline 1781 & 1 & 302 & $703 \$ 040$ \\
\hline 1782 & 2 & 546 & $1: 982 \$ 620$ \\
\hline 1783 & 2 & 783 [??) 560] & $1: 207 \$ 120$ \\
\hline 1784 & 2 & 270 & $901 \$ 360$ \\
\hline 1785 & - & - & - \\
\hline 1786 & 4 & 971 & $2: 499 \$ 720$ \\
\hline 1787 & - & - & - \\
\hline 1788 & 3 & 752 & $1: 774 \$ 170$ \\
\hline
\end{tabular}

Fonte: AHU. Piauí, AHU_CL_CU_016, cx.11, d. 646, d. 656, d. 666, d. 669, d. 693, d. 700. 
QUADRO 6: Gado das fazendas da Administração Real (Piauí) conduzidos para Capuame / Inspeção: Nossa Senhora do Nazaré (1770-1788)

\begin{tabular}{|l|r|r|r|}
\hline ANO & $\begin{array}{r}\text { NÚMERO DE } \\
\text { BOIADAS }\end{array}$ & TOTAL DE RESES & PRODUTO LÍQUIDO \\
\hline $\mathbf{1 7 7 0}$ & 2 & 552 & $959 \$ 420$ \\
\hline $\mathbf{1 7 7 1}$ & 2 & 617 & $1: 163 \$ 200$ \\
\hline $\mathbf{1 7 7 3}$ & 1 & 326 & $585 \$ 560$ \\
\hline $\mathbf{1 7 7 2}$ & 2 & 543 & $1: 041 \$ 880$ \\
\hline $\mathbf{1 7 7 4}$ & 2 & 579 & $844 \$ 080$ \\
\hline $\mathbf{1 7 7 5}$ & - & - & $1: 754 \$ 360$ \\
\hline $\mathbf{1 7 7 6}$ & 3 & 854 & $1: 294 \$ 200$ \\
\hline $\mathbf{1 7 7 7}$ & 2 & 642 & $1: 005 \$ 240$ \\
\hline $\mathbf{1 7 7 8}$ & 2 & 568 & $1: 647 \$ 440$ \\
\hline $\mathbf{1 7 7 9}$ & 2 & 591 & $1: 258 \$ 320$ \\
\hline $\mathbf{1 7 8 0}$ & 2 & 590 & $646 \$ 160$ \\
\hline $\mathbf{1 7 8 1}$ & 1 & 305 & $1: 916 \$ 800$ \\
\hline $\mathbf{1 7 8 2}$ & 2 & 597 & $1: 183 \$ 000$ \\
\hline 1783 & 2 & 595 & $1: 817 \$ 460$ \\
\hline $\mathbf{1 7 8 4}$ & 2 & 627 & $641 \$ 200$ \\
\hline $\mathbf{1 7 8 5}$ & 1 & 237 & $1: 475 \$ 320$ \\
\hline $\mathbf{1 7 8 6}$ & 3 & 725 & $546 \$ 760$ \\
\hline $\mathbf{1 7 8 7}$ & 1 & 250 & $773 \$ 580$ \\
\hline $\mathbf{1 7 8 8}$ & 2 & 513 & \\
\hline & & & \\
\hline
\end{tabular}

Fonte: AHU. Piauí, AHU_CL_CU_016, cx.11, d. 646, d. 656, d. 666, d. 669, d. 693, d. 700.

Todas as boiadas que iam das fazendas da Administração Real do Piauí para feira de Capuame seguiam acompanhadas por uma guia contendo informações valiosas tais como o nome do condutor ou passador principal, aquele responsável por toda a travessia das boiadas, a quantidade de cavalos e homens encarregados de trabalhar na condução do rebanho. Havia uma hierarquia bem estabelecida entre os trabalhadores. Em um primeiro lugar estava colocado o condutor ou passador principal, depois estavam os tangedores (em geral homens livres ou forros alugados), seguidos pelos guias e por último os cargueiros (muitas vezes escravos das próprias fazendas da Administração Real do Piauî).

Com base nas trinta e seis guias restantes contendo as informações sobre as boiadas encaminhadas para a feira de Capuame durante a década de 1770, foi possível montar um breve quadro da etnia e condição jurídica dos 
trabalhadores responsáveis pela condução dos rebanhos até o litoral da capitania da Bahia.

TABELA 1: Etnia e condição jurídica dos trabalhadores das fazendas da Administração Real do Piauí (década de 1770)

\begin{tabular}{|c|c|c|c|c|}
\hline & Escravo & Livre & Forro & Liberto \\
\hline Angola & 1 & - & - & - \\
\hline Branco da terra & - & 1 & - & - \\
\hline Crioulo & 12 & 1 & 2 & - \\
\hline Índio & - & 46 & 2 & - \\
\hline Mameluco & - & 1 & - & - \\
\hline Mestiço & 10 & 5 & 1 & - \\
\hline Mulato & - & 5 & 2 & - \\
\hline Pardo & - & 2 & 1 & - \\
\hline Preto & 9 & 4 & 4 & 1 \\
\hline Não identificado & 117 & 66 & 14 & - \\
\hline TOTAL & 149 & 131 & 26 & 1 \\
\hline
\end{tabular}

Fonte: AHU. Piauí, AHU_CL_CU_016, cx.11, d. 646, d. 656, d. 666, d. 669, d. 693, d. 700.

Chama atenção entre os dados arrolados a quantidade de homens escravizados empregados nos ofícios vinculados ao auxilio no transporte dos bovinos piauienses. Cada boiada contava com uma média de seis cativos ocupando os cargos mais baixos, tais como guias e cargueiros. A quantidade de indígenas ocupados no lide com o gado também chamam atenção. Certamente, para o período recortado pelo documento, esta era uma exceção se comparado a maioria das fazendas de gado, visto tratar-se de fazendas pertencentes a jesuítas conhecidos catequizadores e administradores de aldeamentos. 99

Em levantamento feito através da consulta ao Sr. Martinho de Mello e Castro sobre as fazendas do Fisco Real em 1790, foi proposto que deixassem de encaminhar gado diretamente à Capuame para vendê-las nas próprias fazendas. Nos 18 anos em que abasteceram a cidade Salvador, saiu das fazendas piauenses confiscadas dos jesuítas o total de 33.532 cabeças correspondentes ao lucro líquido de 40:945\$926. Se nestes anos o rendimento médio foi de 4:274\$773, com a arrematação das boiadas nas fazendas da Administração Real a serem comercializadas diretamente nas fazendas era possível atingir o montante de 8:328 $\$ 500$, praticamente o dobro do lucro

99. Para um debate sobre a presença indígena e africana nas fazendas de gado vaccum, ver resumidamente o trabalho de: Antonio Roberto Alves Vieira. Família escrava e pecuária: revisão historiográfica e perspectivas de pesquisas. São Paulo, 2011. 
obtido no envio das reses para Capuame. ${ }^{100}$ Não se sabe ao certo se foi decidido dar continuidade ao envio de gado à Capuame depois de 1790, mas certamente o Piauí continuou sendo um grande fornecedor de bovinos para Salvador ainda no século XIX.

Depois dos sertões pertencentes à capitania do Piauí, o sertão mais mencionado como local de origem das boiadas na feira de Capuame era as imediações do Rio São Francisco. Isoladamente, o gado vindo do rio São Francisco ocupava o primeiro lugar como fonte de abastecimento. O termo genérico de sertão do Rio São Francisco trás uma dificuldade na precisão dos pontos específicos onde estavam as unidades produtivas, pois devido a extensão do rio, podiam ser várias as paragens agregadas igualmente pelo termo como se fosse uma área próxima e contígua. Tudo leva a crer que o sertão do Rio São Francisco correspondia a região próxima ao seu curso médio e baixo em ambas as margens.

A travessia do rio provavelmente não se caracterizava enquanto um problema para os condutores de gado visto ser feita pela Passagem do Juazeiro, ponto tradicional onde trabalhavam barqueiros e demais profissionais especializados em auxiliar no cruzamento de uma margem para outra. Lá era cobrado um espécie de direito de passagem administrado por um arrematador. ${ }^{101}$ A região da Passagem do Juazeiro foi inicialmente ocupada pelos membros da Casa da Torre, depois de exterminados e apresados muitos índios guaisquais e galaches com auxílio do mestre de campo Guedes de Brito. O pedido de sesmaria pelos "práticos do sertão" causou rivalidade e desavença entre as duas famílias que almejavam igualmente receber as terras da região. ${ }^{102}$ A missão da Passagem do Juazeiro foi estabelecida em 1706 por padres franciscanos, impulsionando a circulação e consolidando a ocupação da movimentada região que ligava a Bahia ao Piauí. ${ }^{103}$

O sertão do Rio São Francisco mostrou-se desde a século XVII como um ponto de referências aos sertanistas, missionários e tropas ${ }^{104}$. Em suas margens foram várias as unidades produtivas construídas ainda nos primeiros momentos de ocupação dos sertões. ${ }^{105}$ As sesmarias de mais de dezesseis léguas próximas ao rio das Cabaças doadas ao sargento-mor Damião da Rocha, ao capitão Francisco de Brá, Antonio de Soutto de Macedo e a Theodósio da Rocha, possivelmente aparentados entre si e pertencentes as primeiras expedições de reconhecimento do território, discriminam a razão de

\footnotetext{
100. AHU. Piauí, caixa 7. "Consulta ao Sr. Martinho de Mello e Castro a rspeito do que fazer com as boiadas das Fazendas dos Jesuítas" 7 de janeiro de 1790.

101. AHU. Piauí Caixa 4.27 setembro 1786.

102. Mônica Sepúlveda Fonseca. Viúvas na corte do sertão: família, gênero e riqueza em Juaz̧eiro (1850-1890), UFBA, Salvador, 2011. p. 25.

103. Idem

104. Diogo Ramada Curto. op. cit.

105. Sobre a ocupação do sertão do rio Sã Francisco, ver: Gabriela Amorim Nogueira. "Viver por si", viver pelos seus: família, comunidades de escravos e forros no "certam de sima do Sam Francisco"( 1730-1790). UNEB, Santo Antônio de Jesus, 2011.
} 
ser das propriedades: "povoar e aproveitar com seus gados".106 Segundo o documento de 1658, eles já eram moradores e criadores de gado no distrito do rio São Francisco e pediam as terras confrontantes com as sesmarias do mestre de campo Nicolau Aranha Pacheco ${ }^{107}$ e dos capitães Francisco de Brá, Damião da Rocha e Balthazar Faria por estarem devolutas "por serem desertas e de ruim serventia". ${ }^{108}$

Antonio Guedes de Brito, seu filho Antonio de Brito e Correia ${ }^{109}$ e o exgovernador Bernardo Vieira Ravasco ${ }^{110}$ eram alguns dos membros da elite baiana que possuíam sesmarias no sertão do Rio São Francisco. Próximo ao alto São Francisco, nas margens do rio Verde foram estabelecidas as fazendas de gado do mestre de campo paulista Mathias Cardoso, seguido por seu filho Januário Cardoso de Almeida Brandão e os demais participantes de expedições e jornadas destinadas à exterminar e reduzir os indígenas dos sertões que também receberam terras na região. ${ }^{111}$

Com a mesma quantidade de referências que o sertão do Piaú isoladamente (sem levar em consideração as outras partes da capitania piauiense) aparece o sertão de Tucano. De acordo com relato deixado por Antonil, o sertão de Tucano distanciava-se da cidade de Salvador cinquenta léguas. ${ }^{112}$ A freguesia de Santo Antonio do Tucano foi ocupada primitivamente por um aldeamento jesuíta de índios cariris. As terras pertenciam genericamente a Casa da Torre, mas parte da sesmaria foi doada no início do século XVIII a João Rodrigues Barroso. ${ }^{113}$ Próxima ao rio Itapicuru, a região inteira é dominada pelo Aquífero Tucano, conhecido até hoje pela fertilidade e a multiplicidade de leguminosas típicas da região de caatinga produzidas há muito nos arredores. ${ }^{114}$ Talvez devido a alta umidade e quantidade de aguadas, o sertão do Tucano figure entre um dos locais de maior produção do gado direcionado à feira de Capuame entre os anos de 1784 e 1789.

O sertão do Morro do Chapéu é citado em quarto lugar como região de origem das boiadas comercializadas na feira de Capuame, com menos da metade de ocorrências do terceiro lugar na lista. Ali foram descobertas minas

106. Tatiana da Cunha Peixoto. Os mandarins do sertão: os criadores de gado do São Francisco. UFMG, Belo Horizonte, 2006, p. 37. DH. 20 de novembro de 1658, vol. 19, p. 422.

107. O terço de Nicolau Aranha Pacheco nomeou vários militares para distintas patentes no ano de 1758. Ver: DH. Vol. 19. "Registro da patente de capitão Francisco Lob o", p. 10; "Registro da patente de capitão Manoel Homem Tellis na Companhia de que o foi Pedro de Araújo”, p. 95, entre outros.

108. DH. 20 de novembro de 1658, vol. 19, p. 422.

109. DH. Vol. 18, p 346-347.

110. DH. Vol. 21, p. 185.

111. Tatiana da Cunha Peixoto, op. cit., p. 62.

112. André João. Cultura e Opulência do Brasil por suas drogas e minas etc. [1711] (Introdução e notas de Andrée Mansuy Diniz Silva). São Paulo, 2007, p. 287.

113. Jadilson Pimentel dos Santos. "Igreja de Santana de Tucano: uma joia Barroca dilapidada." II Encontro Baiano de Estudos em Cultura. Feira de Santana, 2009.

114. Domingos Benício Oliveira Silva Cardoso, Luciano Paganucci de Queiroz. "Diversidade de leguminosae nas caatingas de Tucano, Bahia: implicações para a fitogeografia do semi-árido do Nordeste do Brasil." Rodriguésia (Impresso), v. 58, p. 379-391, 2007. 
de Salitre em 1704. ${ }^{115}$ O sertão de Jacobina teve a ocupação impulsionada após a descoberta de ouro, facilitando o estabelecimento de fazendas de gado vaccum além de pontos comerciais próximos a vila. Certamente foi um ponto importante e de grande movimentação sertaneja no período setecentista.

O sertão de Itapicuru aparece em sexto lugar dentre os pontos de onde saiam as boiadas sertanejas. Com ocupação iniciada ainda no século XVII, foi devidamente estudado por Monica Duarte Dantas em "Fronteiras Movediças". ${ }^{116}$ Próximo de lá estava o rio Vaz̧a Barris, dando nome ao sertão produtor da mercadoria gado localizado em um dos pontos mais emblemáticos da história baiana do século XIX: a formação do Arraial de Canudos.

Os sertão de Itaim e Canindé apareceram na lista respectivamente em oitavo e nono lugar. Para o cálculo final eles foram incluídos no sertão do Piauí visto estarem todos localizados na capitania do Piauí e pela provável imprecisão com que a origem das boiadas eram registradas na feira de Capuame. Certamente o termo sertão do Piaui abarcava inúmeras regiões distintas mesma que referenciadas com o mesmo adjetivo. $\mathrm{O}$ mesmo deveria acontecer com o sertão do Rio São Francisco, abarcando muitas localidades distintas sobre o mesmo nome.

O sertão de Gurguéia recebeu este nome ainda no século XVII fazendo referência a aldeia indígena dos gurguéias na região, reconhecida pelos sertanistas no episódio de guerra de extermínio anaios na região do rio São Francisco. Próximo a Barra do Salitre foi de lá que os militares nomeados (Francisco Dias de Ávila, Domingos Rodrigues de Carvalho e Domingos Afonso Sertão) para a "guerra do rio São Francisco" contra os tapuías seguiram em direção ao Piauí. ${ }^{117}$

Com dez ocorrências de entrada de gado em Capuame figurava o sertão de Inhamuns. Localizado na ribeira do rio de mesmo nome, pertencia a capitania do Ceará. Lá havia uma caminho que ligava o Ceará ao sul do Piauí, figurando como espaço dos tradicionais litígios de famílias sertanejas. ${ }^{118}$

Todas as outras localidades elencadas na tabela abaixo tiveram entre oito e uma ocorrência nos "Livros de Registro de Entrada de Gado" para os anos de 1784 a 1789. O baixo índice de aparições no documento não significa necessariamente tratar-se de parte com produção de gado inexpressiva. Talvez uma das explicações seja a baixa quantidade de unidades produtivas que estivessem voltadas majoritariamente para a comercialização dos animais ali criados. Todavia esta hipótese requer um olhar mais atento sobre a

\footnotetext{
115. Isnara Pereira Ivo, op. cit., p. 89.

116. Monica Dantas, op. cit.

117. Marcio Roberto Alves dos Santos, op. cit., p. 69 ; Francisco Augusto Pereira da Costa. Cronologia bistórica do estado do Pianí. Rio de Janeiro, 1974; Odilon Nunes. Pesquisas para a história do Piauí. Rio de Janeiro, 1975, vol. 1, p. 71.

118. Nathália Maria Montenegro Diniz. Um sertão entre tantos outros: Fazendas de gado nas Ribeiras do Norte. USP, São Paulo, 2013, p. 189. Billy James Chandler. Os Feitosas e o Sertão dos Inhamuns: a história de uma comunidade no nordeste do Brasil (1700-1930). Fortaleza, Rio de Janeiro, 1981.
} 
documentação restante capaz de trazer uma melhor compreensão sobre o processo de produção e condução das boiadas sertanejas espalhadas pelas abundantes fazendas interioranas do século XVIII.

\subsection{As unidades produtivas}

As fazendas de gado vaccum sempre foram descritas como unidades produtivas montadas e estabelecidas com uma certa facilidade. Baseado principalmente no Roteiro do Maranhão a Goiaz pela capitania do Piaubi, vários foram os pesquisadores que citaram a célebre frase como prova coeva do pouco esforço exigido para a reprodução da sociedade sertaneja:

"Nele pouco se muda na superfície da terra, tudo se conserva quase no seu primeiro estado. Levantada uma casa coberta pela maior parte de palha, feitos uns currais, e introduzidos os gados, estão povoadas três léguas de terra, e estabelecida uma fazenda."119

Até certo ponto a afirmação possivelmente condizia com a realidade dos criadores de gado, principalmente quando comparado com as fazendas dedicadas ao cultivo de produtos agrícolas tais como a cana, tabaco, entre outros. Todavia, a reprodução da afirmação tomada ao pé da letra pode reforçar uma imagem do homem sertanejo como aquele ser associado à natureza, pertencente a uma sociedade a-histórica na qual a desenvolvimento lento das técnicas demonstraria o seu atraso e atrofia nata. ${ }^{120}$

Os currais, metonímia utilizada corriqueiramente nos documentos coevos para caracterizar a parte pelo todo, contavam de fato com a necessidade de pouca mão de obra. Cerca de cinco a seis trabalhadores livres ou escravizados davam conta de cuidar do rebanho e dos lides com a criação em unidades produtivas de médio porte. As maiores fazendas, às vezes de tamanhos desproporcionais, contavam com uma maior quantidade de escravos. Todavia, é difícil discernir, para as propriedades sertanejas, qual era de fato o número de vaqueiros e outros profissionais dedicados exclusivamente ao lide com o rebanho, visto em várias delas haver atividades de cultivo que também requeriam o trabalho de um certo número de cativos, mesmo que as roças não fossem exatamente grandes plantações monocultoras com produção voltada para o mercado.

Nos documentos condizentes às Fazendas da Administração Real localizadas na capitania do Piauí, há várias referências a existência de escravos nas unidades produtivas. No inventário dos bens das propriedades foram arrolados, no ano de 1782,489 escravos para 50.670 cabeças de gado vaccum. ${ }^{121}$ A média seria algo em torno de um escravo para cada centena de bovinos. A

119. "Roteiro do Maranhão a Goiaz pela capitania do Piauhi". RIHGB, Rio de Janeiro, v. LXII, p. 88.

120. Para uma visão crítica sobre o assunto, ver: Renata Santos Rente. Região Geográfica e o regional na literatura brasileira: a representação do sertão em Guimarães Rosa e os debates sobre a formação do Brasil. USP, São Paulo, 2013.

121. AHU. Piauí. Caixa 7. "Consulta ao Sr. Martinho de Mello e Castro a rspeito do que fazer com as boiadas das Fazendas dos Jesuítas". 7 de janeiro de 1790. 
quantidade proporciona é próxima àquela observada nos inventários postmortem analisados. Mas nos dois casos, vale ressaltar: é sempre necessário ter em mente que as unidades não eram exclusivamente dedicadas à pecuária. Por mais que as fazendas fossem caracterizadas como sendo criatórios de gado vaccum, outras atividades produtivas também era realizadas mesmo que em geral fosse pouco documentadas por não serem voltadas para o mercado, como será abordado ainda neste capítulo.

Outro detalhe sobre os inventários post-mortem devem ser levados em consideração logo no início da pesquisa. E para isso tomarei um exemplo coevo. No inventário de Maria Teresa do Bonfim aberto em Caetité no ano de 1814 há uma briga judicial entre os herdeiros devido a uma das partes alegar que o inventariante, o viúvo Capitão José Antonio dos Santos, estava negligenciando informações às autoridades competentes. Afirma, por exemplo, que o número de cabeças de gado avaliado e declarado era muito menor do que de fato haviam nas fazendas da família. Segundo José Ignacio da Silva, genro da falecida, seu sogro omitira a existência de mais de 400 reses na Fazenda Olhos D'Água, prontificando-se a ir até a propriedade, ferrar as crias e trazer em juízo os papéis da "contagem da ferra do gado". Mas as acusações contra o viúvo Capitão José Antonio dos Santos não pararam por aí. Os genros também alegaram que o inventariante mentiu sobre o valor pelo qual vendeu as reses existentes nas fazendas, declarou um valor maior daquele pago ao capitão do mato responsável pela captura de um escravo fugido, Gonçalo e por fim afirmaram que as dívidas de João Paulo de Souza, Francisco José da Silva, Antonio Aulerio de Mourais tinham sido recebidas pelo sogro que não as havia declarado alegando ser difícil receber o valor dos herdeiros por estarem já todos mortos. ${ }^{122}$

Ora, já era de se esperar que nem todos os bens arrolados condizessem de fato com as propriedades das famílias que entravam em litígio devido a morte de um dos membros. Certamente, aquilo que podia ser negligenciado, para inclusive diminuir as custas com o inventário, o seria. Isso acontece até hoje. É possível que familiares dos defuntos buscassem esconder dinheiro vivo ou vender boiadas inteiras antes dos bens serem avaliados, na medida em que era fácil negociar as reses rapidamente. Já a posse de escravos é um dado mais confiável na medida em que havia uma dificuldade em sonegar um bem tão valioso. Diante disso, nossa única conclusão é que os dados sobre as fazendas de gado vaccum não são nem um pouco confiáveis. Todavia,como nos lembra a máxima judaica: "é o que temos para hoje". 
TABELA 2: Relação entre produção pecuarista e posse de escravos (século XVIII)

\begin{tabular}{|l|r|r|r|}
\hline & $\begin{array}{r}\text { De 01 a 04 } \\
\text { escravos }\end{array}$ & $\begin{array}{r}\text { De 05 a 09 } \\
\text { escravos }\end{array}$ & $\begin{array}{r}\text { Acima de 10 } \\
\text { escravos }\end{array}$ \\
\hline Pequena: 1 a 99 reses & 10 & 3 & 1 \\
\hline Média: 100 a 499 reses & 2 & 3 & 4 \\
\hline Grande: $\mathbf{5 0 0}$ a 1000 reses & 2 & 4 & 3 \\
\hline
\end{tabular}

Fonte: APEB. Secção Judiciário. Inventários post-mortem.

De acordo com o quadro que foi possível montar com base nos dados arrolados a partir dos inventários post-mortem restantes de pessoas envolvidas diretamente com o comércio de gado das unidades produtivas até a feira de Capuame ${ }^{123}$ há uma evidente preponderância das pequenas propriedades rurais, com criação pecuarista de pequeno porte, acompanhada pelo trabalho de poucos homens e mulheres escravizadas.

Certamente as fazendas que possuíam um pequena quantidade de criação de gado e apareciam com mais de cincos escravos contavam com a produção agrícola de mercadorias ou outros produtos que empregavam a maior parte do trabalho escravo. Assim como as fazendas pecuarista de grande porte que possuíam poucos escravos certamente contratava uma quantidade significativa de trabalhadores livres que dessem conta de todos os afazeres que uma grande produção de gado requeria. Estes trabalhadores livres podiam ser tanto uma espécie de assalariado que recebia uma parte da produção como forma de remuneração de seu trabalho, como podia ser um "agregado" que retribuia um "favor" do fazendeiro, ou seja, uma relação pautada na troca do acesso a terra tendo como contrapartida a disponibilização de sua força de trabalho para fins diversos. ${ }^{124}$

Ao contrário do que pode parecer, a pecuária requer constante vigilância dos trabalhadores sobre o rebanho, em especial nas regiões de criação extensiva em que muitas vezes não havia cerca de nenhum tipo que salvaguardasse as reses das propriedades nas décadas iniciais. Muros feitos de pedra, cercas construídas com paus ou plantas espinhosas só fariam parte do

123. Vale relembrar que o critério para a seleção dos inventários foi a busca por documentos daqueles criadores e condutores que tiveram o nome arrolado nos "Livros de Registro de Entrada de Gado" da Feira de Capuame (1784-1789).

124. Para uma discussão sobre o papel do agregado e a sutiliza com que o termo esconde uma relação de trabalho e dependência, ver: Renata Rente, op. cit, p. 107-109. 
cenário sertanejo em finais do século XVIII. ${ }^{125}$ As vacas prenhas e paridas precisavam ser observadas atentamente para não se embrenharem em matos ou passarem por dificuldades durante o trabalho de parto. Depois de nascidos, os novilhos (juntamente com as vacas paridas) ficavam em uma parte específica da fazenda, o curral. Coberto de palha, com estrutura de madeira, ali todos os dias um funcionário precisava tirar o leite da fêmea, observar o comportamento ou os possíveis cuidados necessários com os bezerros.

O restante do rebanho ficava sob constante vigilância dos trabalhadores que percorriam a propriedade à cavalo para conseguirem localizar todas os bovinos pertencentes à fazenda. Segundo o quadro elaborado a partir dos dados dos inventários post-mortem, foi possível verificar a quantidade de montarias existente em cada fazenda. A regra geral quanto as montarias era uma proximidade entre o número de cativos e o número de gado cavalar. Isso não significa que a montaria era destinada a servir aos escravos. Certamente os cavalos só eram utilizados pelos vaqueiros especializados que podiam ser livres ou escravizados. O mais curioso sobre o gado cavalar foi a localização de inventários com grande quantidade de cavalos, éguas e potros. Nove fazendas sertanejas contavam com mais de vinte cavalos, sendo duas delas com mais de quatrocentos animais, certamente unidades produtivas especializadas na reprodução das montarias. ${ }^{126}$

Cuidar das bicheiras, espantar animais peçonhentos e ferozes era uma das muitas tarefas dos vaqueiros e boiadeiros dedicados aos múltiplos cuidados com o rebanho. Carrapatos, bernes, sarnas e outros problemas recorrentes no gado bovino podem ocasionar não só lesões no couro dos animais (diminuindo o seu valor), mas também provocar perda de peso devido ao desgaste e incômodo do animal com a presença parasitária. ${ }^{127}$

A idade média do gado para chegar ao ponto de abate era de quatro anos. Esta também era a faixa etária em que a vaca estava pronta para dar a cria pela primeira vez. ${ }^{128}$ A gestação da vaca leva nove meses, tendo por intervalo médio entre uma cria e outra o período aproximado de vinte e dois meses. Depois de nascido, o bezerro permanece por volta de três meses confinado no curral. ${ }^{129}$ Internamente ao rebanho há uma diferença entre o bezerro, novilho e garrote, marcada sobretudo pela idade em que a cria se encontra. Dado a quantidade de chocalhos arrolados nos inventários postmortem, vários deles certamente andavam com os instrumentos pendurados no pescoço, sobretudo aqueles em condição mais vulnerável que precisavam ser vigiados com mais atenção.

\footnotetext{
125. Edison Rodrigues de Souza; Walter Fagundes Morales. Prospeçãa Arqueológica e Educação Patrimonial para a linha de transmissão 230 KVI Igaporã - Bom Jesus da Lapa II. Ilhéus, 2013; Caio Prado Junior. História do Brasil Contemporâneo. São Paulo, 1986, p. 199. p.226

126. O inventário contendo fazendas que possuíam acima de 400 cabeças de gado cavalar pertenciam a Antonio Pereira Pinto. APEB. Seção Judiciário. 02/728/1194/05. Carinhanha 1815.

127. Danilo Gusmão de Quadros. Sistemas de produção dos bovinos de corte. UNEB, Salvador, 2005.

128. Maximiliano (Príncipe de Wied-Neuwied). Viagem ao Brasil. São Paulo, 1989 [1816], p. 383.

129. Lycurgo do Santos Filho. Uma comunidade rural no Brasil Antigo (aspectos da vida patriarcal na sertão da Babia nos séculos XVIII e XIX). São Paulo, 1956, p. 209.
} 
Ao que tudo indica, não era costume fazer grandes melhorias na forragem das terras destinadas à pastagem dos animais. $\mathrm{O}$ capim mais comum, pelo que aponta os pesquisadores, era o braquiária ou capim Angola. ${ }^{130} \mathrm{Na}$ caatinga, a forragem podia ser também encontrada durante a estação seca graças a presença abundante de tipos distintos de cactos na região. $O$ mandacaru e o xique-xique resistem a períodos prolongados de escassez de água e servem de alimento para os animais. O caule do coqueiro também podia servir como fonte de nutriente para o rebanho em momentos de estiagem. Com ele era possível produzir uma farinha. ${ }^{131} \mathrm{Nas}$ grandes unidades produtivas, podia acontecer dos pastos serem utilizados em uma espécie de sistema de rotatividade, ou seja, parte do pasto ficava fechado durante o período de chuva para manter-se verde e forrado por um período maior durante as secas, momento em que o rebanho seria então direcionado para o pasto não consumido, garantindo que o índice de mortalidade dos bovinos fosse o menor possível, acarretando menos prejuízos. Evidente que este esquema só se mostrava viável nas grandes fazendas cuja quantidade de terra nunca foi um problema.

Para os proprietários dos pequenos rebanhos prevalecia o uso comunal dos pastos. Mesmo nas fazendas de médio a grande porte, podia ocorrer do proprietário permitir que os moradores dos arredores ou até mesmo trabalhadores da fazenda e agregados deixassem o gado pastando junto com o rebanho principal. ${ }^{132}$ Esta prática era bem difundida, sendo comum nos inventários post mortem a localização de informações sobre rebanhos empastourados em sítios ou fazendas de outras pessoas que não o dono da boiada.

A fazenda Pancarahy pertencente a Pedro José de Souza e Florinda da Costa, tinha por vaqueiro Eugenio Machado, mas nela também morava o casal Paulino Pereira e Rosa Barbosa, natural de Pambu ${ }^{133}$. Entre as dívidas arrolada no inventário de Rosa Barbosa e Paulino Pereira aparece Pedro Leite (morador na Vila de São João, mas presente na fazenda Pancarahy no momento de abertura do inventário), Geraldo Soares, Nicolau Pereira moravam na mesma fazenda. Em Pancarahy também habitavam Manoel José de Carvalho, Paulo Pereira ( casado com Rosa Maria, filha de Antonio Pereira da Costa), Silvestre Gonçalves Feitoza, Atanasio Nunes. Antonio Pereira da Costa e sua esposa Isabel Ferreira moravam na mesma fazenda com o filho Manoel Pereira, casado com Silvana Ferreira, mais dois filhos menores de 25 anos e três

\footnotetext{
130. Manuel Correia de Andrade. A terra e o homem no nordeste: contribuição ao estudo da questão agrária no nordeste. São Paulo, 2005.

131. Lycurgo do Santos Filho, op. cit., p. 209.

132. Sobre as comunidades de fundo de pasto na Bahia, ver: Andréa Alves de Sá. Território de uso comum das comunidades tradicionais: uma visão jus socioambiental do criar, faz̧er e viver dos fundos de pasto da Babial Brasil. UFPR, Curitiba, 2010.

133. APEB. Paulino Pereira e Rosa Barbosa 08/3406/08 Jacobina 1814.
} 
escravos, ${ }^{134}$ assim como seus parentes Maria Ferreira de Araujo e Antonio Ferreira Pedrosa. ${ }^{135}$

Na fazenda das Lajes, sertão do Caetité, morava o casal Maria Bernarda de Jesus e Manuel Fernandes da Cunha, ${ }^{136}$ João Martins da Cruz e Bento José de Souza (parentes de Manuel Fernandes da Cunha). ${ }^{137}$ Antonio João da Silva possuía 100 cabeças de gado na mesma fazenda. ${ }^{138} \mathrm{O}$ vaqueiro da fazenda das Lajes era João Martins da Cruz e possuía dívidas com o casal Paulino Pereira e Rosa Barbosa, moradores da fazenda Pancarahy. ${ }^{139}$

As primeiras fazendas, de modo geral, foram estabelecidas próximo a rios, córregos e lagoas. Certamente a localização privilegiada dos currais cabia aos sesmeiros e sertanistas responsáveis pela frente de expansão dos domínios portugueses e seus descendentes. ${ }^{140}$ Aos agregados, membros menos destacados das primeiras expedições sertanejas ou sitiantes cabiam as regiões menos favoráveis, nem sempre com acesso direto à água, precisando depender da "boa vontade" grandes proprietários para conseguirem chegar aos rios, quando não fosse possível cavar poços ou cacimbas. O controle sobre recursos naturais e meios de produção significava poder concentrado nas mãos dos grandes fazendeiros com quem favores e trabalho podiam ser trocados por acesso a terra e suprimentos básicos especialmente em momentos de carestia.

Entretanto, é necessário ter em mente que os sertões baianos não formavam uma paisagem homogênea composta por um tipo singular de relação social. Pelo menos enquanto a territorialização colonial ainda não havia se espraiado por completo. Lembremos que a própria ideia de "fertilidade da terra" também é historicamente construída. ${ }^{141}$ Muito mais múltiplo do que a imagem estereotipada constantemente reproduzida, certamente os sertões setecentistas eram ainda menos parecidos com esta ideia de um solo castigado no qual predominava única e exclusivamente o mandonismo de coronéis. Evidente que esta forma social tendia a se generalizar na medida em que as fronteiras foram sendo fechadas e o acesso a terra tornou-se cada vez mais

\footnotetext{
134. APEB. Antonio Pereira da Costa 07/3224/01 Joazeiro 1800.

135. APEB. Maria Ferreira de Araujo e Antonio Ferreira Pedrosa. 08/3474/01 Joazeiro, 1777

136. APEB. Maria Bernarda de Jesus ; 07/3186/05 Rio de Contas 1796 e 02/578/1030/03. Caetité 1800.

137. Idem

138. APEB. Antonio João da Silva (Jacobina 1804) 08/3406/04.

139. APEB. Paulino Pereira e Rosa Barbosa 08/3406/08. Jacobina 1814.

140. Este foi o caso de Mathias Cardoso. O sertanista paulista ocupou primeiramente as terras entre os rios São Francisco e rio Pardo e Doce, deixando aos outros participantes menos destacados das jornadas do sertões as terras menos favoráveis. Marcio Santos, op. cit. , p. 211.

141. Maria Yedda Leite Linhares. "A pecuária e a produção de alimentos na colônia”. Tamás Szmrecsányi (org.) Históra Econômica do Periodo Colonial. São Paulo, 2002. p. 116. ; Ester Boserup. The conditions of agricultural growth. The economics of agrarian change under population pressure. London, 1965, p. $9 \mathrm{e}$ segs; Charles Tilly (ed.) Historical studies of changing fertility. Princenton, 1978.
} 
difícil. ${ }^{142}$ Todavia, os sertões baianos do século XVIII ainda permitiam a reprodução de espaços de sombra nos quais o poder colonial, personificado pela figura dos "práticos dos sertões" possuidores de patentes militares e grandes sesmeiros, ainda não havia penetrado inteiramente por diversos motivos. Por ora, vale lembrar que os sertões (de modo geral) configuravam-se como o espaço privilegiado para a montagem de quilombos ${ }^{143}$, viabilizando o deslocamento e manutenção de zonas dominadas por índios brabos ${ }^{144}$, possibilitando a itinerância dos ciganos e eremitas ${ }^{145}$. Permitia ainda a permanência de posseiros em terras de difícil acesso, o estabelecimento de comunidades de fundo de pasto, ${ }^{146}$ além de outros tipos de apropriação da terra capazes de permitir a reprodução de outros modos de vida com relativa independência em relação aos grandes sesmeiros, mesmo que isso fosse momentâneo. Vale lembrar, como bem demonstrou Marcio Santos que a ocupação sertaneja não ocorreu de modo contínuo e contíguo. ${ }^{147}$

No que diz respeito a imagem dos sertões totalmente identificados por suas condições naturais, podemos logo de início anunciar que possivelmente nem todas as partes interioranas eram compostas por caatingas brabas, solos constantemente rachados pelo calor escaldante e distantes de rios perenes e aguadas. Evidente que há características que permaneceram pelos séculos, todavia, estudiosos são enfáticos em apontar a constante ação do homem através de derrubadas e queimadas de vegetação para abrirem pastos como um dos fatores mais relevantes para a deterioração paulatina dos solos sertanejos. ${ }^{148}$ O próprio pisoteio do gado sobre o mesmo espaço por séculos tem um impacto ambiental tremendo, impedindo a recomposição da vegetação. ${ }^{149}$ A situação tende a piorar devido ao baixo índice pluviométrico a qual a região encontra-se submetida. ${ }^{150} \mathrm{E}$ na medida com que há desmatamento e uma baixa quantidade de plantas para facilitar o processo de evaporação, a situação de falta de chuvas ficava ainda mais drástica. Este é o fenômeno conhecido como processo de desertificação que afetou durante séculos outros lugares do globo além dos sertões baianos. O sul dos Estados

142. Acompanhando o raciocínio de Renata Rente, cabe como hipótese desta dissertação a necessidade contextualizar os fenômenos do coronelismo e mandonismo dos sertões, não sendo possível generalizar estas relações sobretudo para o período colonial por mais que evidentemente os grandes sesmeiros e homens de patentes tivessem o monopólio sobre a terra e exercessem um poder irrestrito, condizente com o seu papel de reptesentante régio no interior.

143. Flávio dos Santos Gomes. A hidra e os pântanos: mocambos, quilombos e comunidades de fugitivos no Brasil ( séculos XVII-XIX). São Paulo, 2005, p. 405.

144. Maria Hilda Baqueiro Paraíso. O tempo da dor e do trabalbo: a conquista indígena nos sertões do leste. USP, São Paulo, 1998.

145. José D'Oliveira China. Ciganos do Brasil: subsidios históricos, ethnographicos e linguísticos. São Paulo, 1936; Alexandre José de Moraes Mello. Os ciganos no Brasil e o cancioneiro dos ciganos. Belo Horizonte, 1981.

146. Andréa Alves de Sá. op. cit.

147. Marcio Santos, op. cit.

148. Marta Celina Linhares Sales. Estudos climáticos, morfo-pedológicos e fito-ecológicos no núlceo de desertificação de Iraucuba-CE. USP, São Paulo, 2003.

149. Larissa Giroldo. Terracetes de pisoteio de gado mudanças morfo-pedológicas em vertente amostral na bacia bidrogŕofica do rio Jacareí, Serra da Mantiqueira - SP. USP, São Paulo, 2013.

150. Marta Celina Linhares Sales, op. cit. 
Unidos, também dedicado majoritariamente à pecuária, possui uma paisagem muito semelhante, apesar das condições históricas e políticas abissalmente distintas. ${ }^{151}$

De modo geral, durante o século XVIII as fazendas de gado tendiam a ficar distantes uma das outras, com exceção dos locais mais concorridos, tais como as margens dos rios perenes ou as beiras das Estradas Reais ou Estradas das Boiadas mais movimentadas, sendo possível andar por um dia inteiro sem avistar vestígio de morada ou ser humano, segundo alguns relatos. ${ }^{152} \mathrm{O}$ testemunho pode parecer exagerado, mas levando em consideração o tamanho das propriedades, a quantidade de grandes pastos separados por matas, garantidoras do constante fornecimento de lenha, as zonas de expansão das unidades produtivas e a ocupação descontínua dos sertões no período setecentista, é possível de fato que as sedes fossem distantes umas das outras. As casas dos agregados, trabalhadores, sitiantes talvez fossem mais próximas até mesmo por uma questão de segurança e rearranjo espacial. Tudo leva a crer que o círculo de convivência das mulheres e homens sertanejos, no que diz respeito a sua vizinhança mais próxima, era relativamente reduzido se não fosse o tamanho das famílias estendidas. Todavia tal realidade no século XVIII não era uma peculiaridade dos moradores dos sertões baianos. ${ }^{153}$ Exceto as regiões de mineração e as vilas litorâneas, de certo a baixa densidade demográfica era uma realidade da zona rural, quadro preponderante na colônia.

Assim como foram as elites que deixaram majoritariamente registros documentais sobre sua história, a maior parte dos vestígios, relatos e exemplares de moradias nos sertões baianos se refere a sede e as construções mais opulentas. Há trabalhos de relevo sobre as fazendas sertanejas, tais como a dissertação e a tese de Nathália Maria Montenegro Diniz referentes respectivamente ao sertão do Seridó $(\mathrm{RN})$ e aos sertões do norte do século XIX.154 Ainda faz-se necessário um estudo que leve em consideração as alterações que as estruturas arquitetônicas sertanejas tiveram no decorrer dos séculos, respeitando em grande medida o contexto histórico e social no qual estavam inseridas, diacrônica e sincronicamente. Por ora, será somente levantado uma hipótese a ser melhor argumentada e embasada por estudos futuros sobre as construções e moradias nas fazendas de gado vaccum dos sertões baianos.

151. Mike Davis . Holocaustos Coloniais: Clima, fome e imperialismo na formação do Terceiro Mundo. Rio de Janeiro, 2002; Henry Diaz e Vera Markgraf. El Niño Historical and Paleoclimatic Aspects of the Southern Oscillation. London, 1993.

152. Ver em especial Roteiro do Maranbão, além do Roteiro de Quaresma Delgado e os documentos sobre a exploração do salitre no interior da Capitania da Bahia. AHU. "Ofício do Vice-rei Conde dos Arcos para o Desembargador Jão Pedro Henriques da Silva, em que lhe transmite as instruções necessárias para o desempenho da sua comissão à Serra dos Montes Altos, a que outros documentos se referem." Bahia, 5 de maio de 1758. c. 19, doc. 3474; "Roteiro de Joaquim Quaresma Delgado." Erivaldo Fagundes Neves (org.). Caminhos do sertão. Salvador, 2007.

153. Este tema será melhor analisado no terceiro tópico do presente capítulo.

154. Nathália Montenegro Diniz. Velhas fazendas da ribeira do Seridó. USP, São Paulo, 2008; Nathália Montenegro Diniz. Um sertão entre tantos outros. Fazendas de gado nas Ribeiras do Norte. USP, São Paulo, 2013. 
Entre o século XVII e início do século XVIII é comum encontrarmos ainda algumas informações sobre a construção de abrigos semelhantes a casas-fortes. ${ }^{155}$ A própria ideia de uma casa-forte nos remete a um contexto de guerra, como foi o caso do momento de expansão do domínio português sobre as terras ocupadas inicialmente pelos indígenas. A carta endereçada aos oficiais da Câmara da Bahia em 1657 diz:

"para se evitar a descida dos bárbaros às freguesias se façam algumas casas fortes nas paragens mais convenientes do sertão com infantaria bastante a conservar as aldeias amigas, reduzir ou desbaratar as contrárias e segurar aquela campanha, e com tanta provisão de mantimentos que esteja sempre adiantada para seis meses e tão certa que não haja em seu efeito a menor falência que na suposição de haver eu de mandar trezentos infantes ao menos com o cabo e oficiais necessários vejam Vossas Mercês as petições e façam cômputo do dinheiro que é necessário para a Infantaria, mantimentos, resgates e todos os mais aderentes de que pende a jornada e fábrica das casas-fortes e a conservação delas" 156

Durante o processo de abertura da estrada que ligava a vila de Cachoeira a Borda da Mata da Serra de Orobó ${ }^{157}$, em 1657, foi recomendado ao Sargento-mor Pedro Gomes a construção de uma casa-forte na qual deveria permanecer infantaria bastante para destruir as aldeias contrárias que cismassem em descer dos sertões. ${ }^{158} \mathrm{O}$ regimento do capitão Bartholomeu Aires menciona a "compra" de gado nos currais que havia pelos caminhos para alimentar a infantaria. O capitão deveria tomar de algum destes currais um vaqueiro e negros para assim conduzir a boiada até a casa-forte que havia na passagem do Paraguaçú. ${ }^{159}$ Chegando na casa-forte, matavam os bois necessários para a jornada prosseguir e as demais cabeças ficariam por lá pastando sob a vigilância de um soldado. ${ }^{160}$

Em 16 de setembro de 1672, o ajudante Manuel Fernandes Ferreira pediu aos oficiais da Câmara da Bahia o pagamento de três meses de serviço para cinco soldados seus que foram enviados ao Rio das Piranhas para "fazer uma casa-forte e Armazén para a conducção dos mantimentos da Conquista do Sertão e roçar mattos donde ha de ter algum trabalho" . ${ }^{161}$

155. Márcio Santos reparou acertadamente no papel fundamental das casas-fortes enquanto ponto de apoio e consolidação das fronteiras do Império Português. Márcio Roberto Alves dos Santos, Fronteiras do sertão baiano: 1640-1750. USP, São Paulo, 2010, p. 187 e segs.

156. DH. "Carta fará os oficiais da câmara desta cidade acerca das casas-fortes que se hão de fazer no sertão." 10 de setembro de 1657. vol. 86, p. 138.

157. Segundo nota produzida por Marcio Roberto Alves dos Santos, a Serra do Orobó ficava a 35 léguas a oeste da cidade da Bahia, no extremo norte do atual município de Rui Barbosa. Marcio Santos, op. cit., p. 154.

158. DH. "Regimento que levou o Sargento-mor Pedro Gomes para abrir a estrada desde a Cachoeira té o Orobó”. Bahia, 3 de outubro de 1657. p. 56, vol. 4.

159. DH. "Regimento que levou o Capitão Bartholomeu Aires, que foi por Cabo de quatro Companhias fazer guerra ao Gentio do Sertão ." p. 64, vol. 4

160. DH. "Regimento que levou o Capitão Francisco de Brá jornada do Sertão, e casa forte delle aonde ha de assistir." p. 75 vol. 4

161. DH. "Portaria que se passou aos officiais da Camara para dar três mezes de soccorro ao Ajudante Manuel Fernandes Ferreira e a cinco soldados que leva consigo." 16 de setembro de 1672. p. 109 vol . 8. 
Através da carta patente do sargento-mor Pedro Gomes, promovido a “ Tenente de Mestre de Campo General deste Estado” em 1657, sabemos inclusive de sua rendição a uma casa-forte em poder dos flamengos, no qual o assalto resultou no prejuízo do inimigo que perdeu na ocasião "uma companhia de cravinas ${ }^{162}$, e uma Casa forte com trinta flamengos, e quarenta e três índios, e três mil cabeças de Gado. "163

O motivo da construção das casas-fortes é evidente: em um contexto hostil, localizado no território em conflito, os ataques indígenas eram extremamente comuns e fazia-se necessário a construção de abrigos resistentes, feitos especialmente de pedra, com observatório e se possível andar subterrâneo. Além disso as casas-fortes acabavam por marcar posição no território. ${ }^{164}$ Eram vistos como pontos estratégicos para servir de base de apoio para outros grupos de sertanistas que passassem pelo local. Constantemente guardadas, as casas-fortes eram rodeadas por roças e pastos para arrebanhar o gado confiscado pelos caminhos. Além de abrigar os membros das expedições, podiam armazenar munição e mantimentos em seu interior por um longo período. Visto que muitos dos primeiros sesmeiros e demais ocupantes dos sertões foram participantes das guerras dos bárbaros é razoável pensar que as casas-fortes poderiam servir como moradia das fazendas de gado vaccum estabelecidas após o término dos conflitos. $\mathrm{Na}$ medida em que mesmo após a consolidação das unidades produtivas era comum os ataques dos indígenas em muitas regiões, é possivelmente imaginar que as primeiras sedes de fazenda assemelhavam-se em muitos aspectos às casasfortes militares. Esse foi o caso da povoação de Santo Antônio da Conquista, no médio Paraguaçu, iniciada em torno de uma casa-forte. ${ }^{165}$

Na segunda metade do século XVII, possivelmente na década de 1680, quando Francisco Machado Peçanha prendeu Luis Albuquerque, por ordem do rei, devido a algumas mortes e outros crimes cometidos, o sertanista "aparentado com os mais poderosos da terra" - foi encontrado em uma casaforte subterrânea, acompanhado por mulatos e negros facinorosos. ${ }^{166}$

$\mathrm{Na}$ medida em que as tensões foram sendo apaziguadas, de acordo com a consolidação do domínio português no século XVIII e com o avançar do processo de apropriação das terras convertidas em unidades produtivas, as fazendas foram ganhando estruturas mais práticas e mais condizentes com as necessidades ambientais da região pacificada, tais como as casas térreas, sedes das fazendas de gado.

162. A companhia de cravinas foi atuante na Guerra de restauração. Podia ser equiparado a algo semelhante a cavalaria.

163. DH. "Registro de patente do sargento-mor Pedro Gomes Provido de Tenente de Mestre de Campo General deste Estado. ” 23 de fevereiro de 1657. vol. 19, p. 118. Mesmo que os números pareçam exagerados, o importante aqui é observar a existência da casa-forte como ponto estratégico de abastecimento nas guerras.

164. Marcio Santos, op. cit., p. 103.

165. Idem, p. 103.

166. DH. "Para a Companhia que vagou por fallecimento do Capitão Manoel Jorge Zambuge ao Ajudante Francisco Machado Peçanha, e ao Alferes reformado D. João Barjon. " 9 de julho de 1691. " vol. 33 p. 414. 
Construídas em geral de pau a pique, taipa de mão, taipa de pilão ${ }^{167}$ ou adobe ${ }^{168}$, podendo ser também de pedra ou material abundante no sertão que estava localizada. Geralmente as melhores casas eram cobertas por telhas de barro ${ }^{169}$ sobre estruturas de carnaúbas ou caibro roliço ${ }^{170}$, ficando a cobertura de palha reservada às casas mais humildes, morada de agregados, trabalhadores livres e escravos. Eram telhadas com duas, três ou quatro águas [caídas]. Possuíam um reboco rudimentar, algumas eram caiadas, ou seja, pintadas com tinta feita a base de água e cal.

Do total de 65 inventários post-mortem de homens envolvidos com a produção ou comércio de gado vaccum, mencionados no "Livro de Registro de Entrada de Gado" da feira de Capoame entre 1784-1789, somente 23 possuíam referência direta às casas localizadas em fazendas de gado entre os bens arrolados. A baixa ocorrência de descrição das moradias tem algumas explicações: a primeira delas diz respeito ao costume de alguns avaliadores em fazer o cálculo do valor da fazenda de "porteira fechada", ou seja, avaliar a unidade produtiva como um todo: as terras e benfeitorias. No inventário do Alferes Francisco Ferreira, morador no sertão do Sento Sé foram arrolados 83 cabeças de gado situadas na Fazenda da Barra, 36 cabeças de gado na Fazenda do Urcú, mais 6 cavalos, 9 escravos, $500 \$ 000$ em dinheiro contado e diversos outros bens. Porém não há menção nem mesmo se a posse de alguma destas fazendas era dele, visto a casa de morada do Capitão José Ferreira Campos ( irmão o Alferes Francisco Ferreira) ser na Fazenda da Barra, além de possuir gado também na Fazenda do Brejo. ${ }^{171}$

O casal Joaquim Maria da Fonseca e Anastacia Barbosa Leite era moradores no sertão de Jeremoabo em 1813. Possuíam três fazendas de gado vaccum e cavalar na região da Ribeira. Nas fazendas Etuâ, Barriguda e Alagoas não foi arrolado mais nenhum bem ou benfeitoria para além da quantidade de bovinos, cavalos e escravos. Devido a quantidade de roupas, joias e louças é razoável pensar que o casal possuía uma moradia própria que simplesmente não foi especificada. ${ }^{172}$

Em outros inventários mostra-se evidente o fato da moradia principal não estar localizada na fazenda criatória e sim no centro da vila e até mesmo na cidade de Salvador. O comerciante Antonio José Viera Araújo possuía um armazém da venda na Missão do Juazeiro coberta de pindoba no Beco do Arruda com cinco portas e uma janela avaliado em $60 \$ 000$ e três casas (uma coberta de telha com paredes de barro com treze portas e três janelas avaliada em 140\$000, a segunda no beco da Rua da Beira do Rio com nove portas e

\footnotetext{
167. Taipa de pilão é uma técnica de construção baseada no uso de terra proveninente de solo argiloso. Era empregada por portugueses e africanos sem indícios de uso da terra para a construção pelos indígenas. Márcia Helena Yamamoto Sato. Análise de estruturas em taipa de pilão. São Paulo, USP, 2011.

168. Tijolo cru, seco ao sol.

169. Gustavo Barroso. Terra do sol: natureza e costumes do norte. Rio de Janeiro, Livraria São José, 1956, p. 191.

170. Nathália Montenegro Diniz. Um sertão como tantos outros. USP, São Paulo, 2013, p. 158.

171. APEB. Alferes Francisco Ferreira 06/2699/08 Sento Sé 1825.

172. APEB. Joaquim Maria da Fonseca 08/3415/14 Jeremoabo 1790.
} 
duas janelas avaliada em $50 \$ 000$ e a última na Rua de Fora coberta de pindoba com duas portas e duas janelas avaliada em 40\$000) no centro da Passagem do Juazeiro. Entre seus muitos bens estava a Fazenda Tapera, no sertão de Cabrobó em Pernambuco com gado e roças além de 98 cavalos e mais bovinos espalhados nas fazendas Alagoa do Boi e Fazenda do Rodiadouro. Nenhuma delas com referência à casas e moradias. ${ }^{173}$ Já as fazendas de gado do Capitão-mor Gonçalo Cerqueira de Couto aparecem todas com a referência de ao menos uma casa de palha e currais. ${ }^{174}$

Por último, muitos dos homens cujos inventários foram compulsados não eram os donos dos currais, tratando-se de posseiros, sitiantes que só tiveram o inventário aberto por deixarem filhos menores de idade e possuírem algumas cabeças de gado, móveis e escravos. Visto não serem os proprietários da terra, talvez também não fossem os donos da própria morada que dividiam com outros parentes e, quem sabe, com seus escravos.

Antonio Pereira da Costa e Isabel Ferreira possuíam quatro filhos maiores de 20 anos. Moravam na Fazenda Pancarahy, na região do Juazeiro com a escrava Maria, nação Angola com 50 anos e seus dois filhos: Miguel de 16 anos e Idwirge de 13 anos. ${ }^{175} \mathrm{O}$ viúvo José Bezerra da Costa, antes de sua morte, morava com o filho Bonifácio, de treze anos na missão da Passagem do Juazeiro do julgado de Santo Sé (comarca de Jacobina). Possuía somente um escravo mestiço de 23 anos chamado Luiz, uma sela ( mas não tinha cavalo), capote, chambre, um par de botas e uma canastra, além de 12 cabeças de gado situadas na Fazenda de São Fidelles. ${ }^{176}$

José Felix de Andrade e sua esposa Ana Maria de São Pedro moravam na fazenda da Tábua, na Serra da Conceição, comarca de Cachoeira, com seus seis filhos (de idade entre 3 e 22 anos) e mais seis escravos. ${ }^{177} \mathrm{O}$ casal Ana Maria Pinto e Pedro Coelho de Sá, moravam em um sítio de terra nas caatingas do povoado de São Peregrino, localizado na povoação de São José da Barra de Sento Sé (Vila de Jacobina). Mesmo que o sítio fosse avaliado em $10 \$ 000$, surpreende o número de escravos: cinco mulheres e sete homens com idade entre dois e 43 anos. Apesar das cangalhas, não foi avaliado nenhum bovino, somente uma besta, além das enxadas, machados e teares, denotando que os escravos possivelmente dedicavam-se a lavoura e até mesmo ao feitio de tecidos de algodão. ${ }^{178}$ Ana Rosalina, moradora no sertão de Jeremoabo, tinha somente entre os bens um par de brincos, sete cabeças de gado e uma escrava Gêge chamada Rita. ${ }^{179}$

Para os casos em que foi possível entrever algumas informações sobre as moradias das fazendas de gado vaccum espalhadas pelos sertões baianos

\footnotetext{
173. APEB. Antonio José Viera Araujo 08/3359/01 Joazeiro 1806.

174. APEB. Capitão mor Gonçalo Cerqueira de Couto Cachoeira 1789.

175. APEB. Antonio Pereira da Costa 07/3224/01 Juazeiro 1800.

176. APEB. José Bezerra da Costa 07/3042/15 Juazeiro 1794.

177. APEB. Ana Maria de São Pedro 02/777/1243/06 Cachoeira 1813.

178. APEB. Ana Maria Pinto 08/3507/03 Jacobina 1791.

179. APEB. Ana Rosalina 07/2869/10 Jeremoabo 1813.
} 
nota-se o costume de registrar o número de portas e janelas como parâmetro para a avaliação do tamanho e valor do imóvel. O material com que era fabricada também aparece com certa frequência, assim como a existência ou não de fechadura nas portas. Segue lista de todas as descrições presente nos inventários:

QUADRO 7: Descrição das moradias das fazendas de gado vaccum dos sertões baianos (século XVIII)

\begin{tabular}{|c|c|c|c|c|}
\hline DONA/O & LOCAL & FAZENDA & DESCRIÇÃO & VALOR \\
\hline $\begin{array}{l}\text { Antonio João da } \\
\text { Silva }\end{array}$ & Juazeiro & Sítio da Barrinha & $\begin{array}{l}\text { coberta de Peridoba (?) } 5 \text { portas e } 2 \\
\text { janelas }\end{array}$ & $30 \$ 000$ \\
\hline $\begin{array}{l}\text { Capitão Antonio } \\
\text { Rodrigues Martins }\end{array}$ & Barra do Salitre & & $\begin{array}{l}\text { Uma casa de morada e oficina de } \\
\text { fazer farinha e roça }\end{array}$ & \\
\hline $\begin{array}{l}\text { Francisco Xavier da } \\
\text { Motta e Sá }\end{array}$ & $\begin{array}{l}\text { São José de } \\
\text { Itapororocas }\end{array}$ & Sítio do Morro & $\begin{array}{l}\text { casa de taipa coberta com telha, uma } \\
\text { porta, } 2 \text { janelas na frente, } 9 \text { portas } \\
\text { no interior e } 1 \text { janela }\end{array}$ & $80 \$ 000$ \\
\hline $\begin{array}{l}\text { Lucas Fagundes } \\
\text { dos Passos }\end{array}$ & Jeremoabo & Gameleira & $\begin{array}{l}\text { terrea coberta de telha taipa de } \\
\text { barro, } 3 \text { portas nessa casa da roça }\end{array}$ & $12 \$ 000$ \\
\hline $\begin{array}{l}\text { Maria Teresa do } \\
\text { Bonfim }\end{array}$ & Caetité & $\begin{array}{l}\text { Fazenda Olhos } \\
\text { d'Agua }\end{array}$ & $\begin{array}{l}1 \text { casa coberta de palha com quatro } \\
\text { portas, } 3 \text { com fechaduras }\end{array}$ & $16 \$ 000$ \\
\hline & & & $\begin{array}{l}1 \text { casa coberta de palha com uma } \\
\text { porta e fechadura } \\
1 \text { casa com paiol coberto de palha } 6 \\
\text { portas com fechadura }\end{array}$ & $\begin{array}{r}3 \$ 000 \\
18 \$ 000\end{array}$ \\
\hline $\begin{array}{l}\text { Custodia Maria } \\
\text { Moreira }\end{array}$ & Itapicuru & $\begin{array}{l}\text { Fazenda } \\
\text { Jabucunam }\end{array}$ & $\begin{array}{l}\text { casa coberta de telha, currais, } \\
\text { cercados e tudo o mais }\end{array}$ & $100 \$ 000$ \\
\hline $\begin{array}{l}\text { Pascoal Correia de } \\
\text { Souza }\end{array}$ & Carinhanha & $\begin{array}{l}\text { Brejo dos } \\
\text { Catulés }\end{array}$ & $\begin{array}{l}1 \text { casa coberta de casca (?), } 4 \text { portas, } \\
3 \text { fechaduras }\end{array}$ & $18 \$ 000$ \\
\hline $\begin{array}{l}\text { Paulino Pereira e } \\
\text { Rosa Barbosa }\end{array}$ & Jacobina & $\begin{array}{l}\text { Fazenda do } \\
\text { Pancarahy }\end{array}$ & $\begin{array}{l}\text { taipa coberta de palha com seis } \\
\text { portas e uma janela }\end{array}$ & $6 \$ 000$ \\
\hline $\begin{array}{l}\text { Alferes Francisco } \\
\text { Pereira da Silva }\end{array}$ & $\begin{array}{l}\text { Santana do } \\
\text { Camisão }\end{array}$ & $\begin{array}{l}\text { Fazenda do Rio } \\
\text { Seco }\end{array}$ & 1 sobrado & $250 \$ 000$ \\
\hline $\begin{array}{l}\text { Manoel Vaz da } \\
\text { Costa }\end{array}$ & Caetité & $\begin{array}{l}\text { Sítio do Brejo } \\
\text { do Cercado }\end{array}$ & $\begin{array}{l}\text { coberta de telhas, } 3 \text { portas com } \\
\text { fechadura, } 2 \text { sem elas }\end{array}$ & $25 \$ 000$ \\
\hline $\begin{array}{l}\text { Antonio Pereira } \\
\text { Pinto }\end{array}$ & Carinhanha & Fazenda Pituba & $\begin{array}{l}\text { coberta de telhas, } 7 \text { portas, } 2 \text { janelas } \\
\text { Casa de telhas }\end{array}$ & $60 \$ 000$ \\
\hline $\begin{array}{l}\text { Capitão mor } \\
\text { Gonçalo Cerqueira } \\
\text { de Couto }\end{array}$ & $\begin{array}{l}\text { São Gonçalo } \\
\text { (Cachoeira) }\end{array}$ & $\begin{array}{l}\text { Fazenda do } \\
\text { Carro quebrado }\end{array}$ & $\begin{array}{l}\text { casa com } 6 \text { milheiros de telha com } \\
\text { dez portas e nove janelas e um } \\
\text { oratório de pedras } \\
\text { Casa de palha }\end{array}$ & $85 \$ 000$ \\
\hline
\end{tabular}




\begin{tabular}{|c|c|c|c|c|}
\hline $\begin{array}{l}\text { Maria Bernarda de } \\
\text { Jesus }\end{array}$ & Caetité & $\begin{array}{l}\text { Fazenda das } \\
\text { Quebradas }\end{array}$ & $\begin{array}{l}\text { coberta de telha com } 2 \text { milheiro, } 7 \\
\text { portas, } 1 \text { janela }\end{array}$ & $30 \$ 000$ \\
\hline $\begin{array}{l}\text { José Antonio de } \\
\text { Farias Lima }\end{array}$ & Geremoabo & $\begin{array}{l}\text { Fazenda Saco } \\
\text { do Capim }\end{array}$ & $\begin{array}{l}\text { morada de casa de telha com } \\
\text { feitorias de curral }\end{array}$ & $30 \$ 000$ \\
\hline Pedro José de Souza & Sento Sé & $\begin{array}{l}\text { Fazenda } \\
\text { Pancarahy }\end{array}$ & coberta de telha & $10 \$ 000$ \\
\hline $\begin{array}{l}\text { Maria Teresa do } \\
\text { Bonfim }\end{array}$ & Caetité & $\begin{array}{l}\text { Fazenda Olhos } \\
\text { dAgua }\end{array}$ & $\begin{array}{l}\text { Coberta de palha } \\
\text { casa com uma porta }\end{array}$ & $\begin{array}{r}16 \$ 000 \\
3 \$ 000\end{array}$ \\
\hline $\begin{array}{l}\text { Constantino Dias } \\
\text { do Vale }\end{array}$ & Caetité & - & Morada de casa & $12 \$ 000$ \\
\hline \multirow[t]{2}{*}{$\begin{array}{l}\text { Capitão Antonio } \\
\text { Rodrigues Martins } \\
\text { dos Santos }\end{array}$} & Jacobina & $\begin{array}{l}\text { Fazenda do } \\
\text { Sargento }\end{array}$ & $\begin{array}{l}1 \text { casa de enchimento coberta de } \\
\text { palha barreado com uma porta com } \\
\text { sua fechadura de ferro }\end{array}$ & $6 \$ 000$ \\
\hline & & & $\begin{array}{l}1 \text { morada de casas novas e grandes } \\
\text { coberta de palha com duas portas, } 1 \\
\text { com fechadura, } 1 \text { janela }\end{array}$ & $30 \$ 000$ \\
\hline \multirow[t]{2}{*}{$\begin{array}{l}\text { Valentim Rodrigues } \\
\text { Teixeira }\end{array}$} & Jacobina & $\begin{array}{l}\text { Fazenda do } \\
\text { Pontal }\end{array}$ & Morada de casa & $50 \$ 000$ \\
\hline & & & $\begin{array}{l}\text { Casa pequena de palha com duas } \\
\text { portas }\end{array}$ & $6 \$ 000$ \\
\hline $\begin{array}{l}\text { João Martins } \\
\text { Santiago }\end{array}$ & Jacobina & $\begin{array}{l}\text { Fazenda da } \\
\text { Juiaca }\end{array}$ & $\begin{array}{l}\text { Morada de casa de telha da ponta da } \\
\text { ilha do Miradouro na beira do Rio } 7 \\
\text { portas com feixaduras }\end{array}$ & $40 \$ 000$ \\
\hline
\end{tabular}

Fonte: $A P E B$. Secção Judiciário. Inventários post-mortem.

Para o fim do século XVIII e sobretudo no século XIX começaram a surgir referências da construção de sobrados pertencentes aos maiores fazendeiros dos sertões, apesar da maior parte das ocorrências ainda ser as imensas casas térreas, sendo muito mais comum a construção de casas assobradadas nos centros das vilas e freguesias. ${ }^{180}$ A residência do Alferes Francisco Pereira da Silva e Maria Angelica do Sacramento na fazenda Gongâ na freguesia de Santo Estevam do Jacuípe era um sobrado avaliado em $250 \$ 000 .{ }^{181}$ No sertão do Seridó, mais especificamente na fazenda Serra Negra, havia em 1813 um sobrado avaliado em 400\$000. ${ }^{182} \mathrm{Na}$ ribeira do Paraíba estava a fazenda do Sobrado, composta por sede opulenta. As fazendas do Recreio e Santa Bárbara são exemplares de unidades produtivas

180. Na pesquisa de Damião Esdras Araújo Arraes é corriqueira a presença de sobrados nas vilas sertanejas. Curral de reses, Curral de almas: urbanização do sertão nordestino entre os séculos XVII e XIX. USP, São Paulo, 2012. Ver também: Junia Motta Antonaccio Napoleão do Rego. Dos sertões aos mares: história do comércio e dos comerciantes de Parnaíba (1700-1950). UFF, Niterói, 2010, p. 48.

181. APEB. Alferes Francisco Pereira da Silva 09/3702/01 Cachoeira 1795.

182. Nathália Mntenegro Diniz. Um sertão entre tantos outros. USP, São Paulo, 2013, p. 91. 
com sobrado nas ribeiras do Rio São Francisco e Alto Sertão Baiano. ${ }^{183}$ Uma casa de sobrado também foi construída na fazenda Canadá, pertencente à Francisco Pinto da Rocha Bastos em meados do século XIX. ${ }^{184}$ A fazendeira dona Helena Genebra de Santa Quitéria morava em um sobrado avaliado em $800 \$ 000$ na fazenda Rosário, freguesia das Itapororocas, quando ditou o seu testamento no ano de $1852 .{ }^{185}$ O capitão Deoclécio Barbosa de Souza também possuía um sobrado na fazenda denominada Boa Vista em Camisão. ${ }^{186} \mathrm{Na}$ fazenda Bom Retiro, pertencente ao capitão Manoel Ferreira havia um sobrado fotografado com toda a pompa, deixando entrever a fonte de riqueza da família: o gado vaccum. ${ }^{187}$

Sobre as casas dos agregados, sitiantes e moradores pobres, há poucos exemplares ainda em pé. Consegue-se fazer uma estimativa do tipo de construção comumente levantada para servir de morada à população mais pobre através das descrições constantes nos inventários post-mortem. É difícil precisar qual era a casa dos agregados e funcionários dos currais somente com base nos bens arrolados, mas podemos deduzir que se a propriedade contava com mais de uma casa e se houvesse uma diferença de padrão entre elas certamente a casa menor e com material menos resistente era a casa dos subalternos devido a hierarquização social reproduzida em todas as esferas de convivência e do cotidiano.

$\mathrm{Na}$ fazenda Olhos D'Água dos criadores Maria Teresa do Bonfim e o capitão José Antonio dos Santos no sertão de Caetité, possuidora de cinco léguas de comprimento e três léguas de largura foram descritas três casas. Certamente em nenhuma delas morava o casal e seus filhos, visto possuírem também uma casa de morada coberta de telha na vila de Rio de Contas. As três casas eram cobertas com palha, sendo uma delas composta por paiol e seis portas com fechadura valendo $18 \$ 000$, a outra contava com quatro portas, sendo três delas com fechadura $(16 \$ 000)$ e por último uma pequena casa com uma porta e fechadura por $3 \$ 000$. É difícil saber em qual delas morava os 14 escravos pertencentes ao casal, dedicados também a plantação de algodão e outros gêneros. De certo a fazenda contava com alguns trabalhadores livres. Todavia esta informação não consta no inventário. ${ }^{188}$

No sítio Quixaba, havia uma casa de palha além da "casa com 6 milheiros de telha com dez portas e nove janelas e um oratório de pedras". 189 $\mathrm{Na}$ fazenda Pedras Brancas de Valentim Rodrigues Teixeira no sertão de Jacobina, arrendada à casa do Mestre de Campo Garcia Dias D'ávila Pereira, existia uma casa de morada do falecido avaliada em 50\$000, sem nenhuma

183. Idem, p. 268.

184. Wlisses Estrela de Albuquerque Abreu. Senhores e escravos do sertão: espacialidades de poder, violência e resistência, 1850-1888. UFCG, Campina Grande, 2011. p. 59

185. Luiz Cleber Moraes Freire. Nem tanto ao mar, nem tanto à terra: agroecuária, escravidão e riqueza em Feira de Santana, 1850-1888. UFBA, Salvador, 2007. p. 116.

186. Idem, p. 127.

187. Eurico Alves Boaventura. Fidalgos e vaqueiros. Salvador, 1989, Ilustrações.

188. APEB. Maria Teresa do Bonfim: 02/566/1018/02 Cetité 1814.

189. APEB. Capitão mor Gonçalo Cerqueira de Couto 02/703/1164/04 Cachoeira 1789 
especificação e mais uma casa pequena de palha com duas portas pelo valor de $6 \$ 000$. Será que era nesta casa pequena de duas portas que moravam os dez escravos do fazendeiro, dentre eles Domingos, mestiço, 30 anos, bem avaliado por se tratar de um bom vaqueiro? Difícil saber. ${ }^{190}$

Através dos inventários é possível encontrar algumas informações sobre as benfeitorias existentes nas fazendas sertanejas. Nem sempre o tamanho das unidades produtivas era mencionado nos documentos compulsados. As informações sobre a produção de alimentos para consumo próprio dos moradores também dificilmente encontra-se arrolado por não ser fonte de renda dos habitantes e também por não ser em uma quantidade absurdamente grande que fosse configurado como uma produção voltada para o mercado e passível de venda, tendo de receber um valor específico. Seguindo esta lógica, as referências à produção agro pastoril arroladas nos inventários diz respeito a benfeitorias que aumentassem o valor da propriedade, assim como as máquinas e utensílios ligados a alguma produção ou manufatura.

Há exceções, como por exemplo a fazenda Olhos D'Água. Lá foram encontrados muitas cabeças de gado vaccum, alqueires de feijão, além de mangueiras, bananeiras, "carboredos de espinho" e "uma extensa cerca que divide uma covada." 191 A fazenda dos Abreus pertencente ao Capitão Antonio Rodrigues Martins dos Santos, localizada em Vila Nova da Rainha, na comarca de Jacobina, contava com "um cercado com seu bananal com algumas árvores de espinho e manga de cerca de pau" avaliado em $30 \$ 000$. Na fazenda do Sargento, o capitão possuía "mangas cercadas de pau" avaliada em $13 \$ 000 .{ }^{192}$ As jaqueiras e bananais também faziam parte da paisagem da Fazenda do Rio Seco na Freguesia de Santana do Camisão. ${ }^{193}$ Será que a produção das frutas em uma grande quantidade era destinada ao mercado ou foram mencionado apenas por tratar-se de áreas cercadas?

Criação de pequenos animais também era comum nas fazendas sertanejas. Nem sempre eram citados entre os bens avaliados nos inventários post-mortem, talvez pela sua quantidade ou valor. Foram arroladas vinte cabras e vinte ovelhas na fazenda do Saco do Capim, ${ }^{194}$ doze cabras na Fazenda Pancarahy, ${ }^{195}$ quarenta na fazenda em que morava Maria Martins da Encarnação, ${ }^{196}$ um chiqueiro de cabras com 60 cabeças do criador Valentim Rodrigues Teixeira ${ }^{197}$, vinte cabeças de cabra pertencentes ao vaqueiro Antonio Ferreira Silva, ${ }^{198}$ entre outros. Ovelhas são citadas nos inventários de

\footnotetext{
190. APEB. Valentim Rodrigues Teixeira 08/3482/12 Jacobina 1795.

191. APEB. Maria Teresa do Bonfim 02/566/1018/02 Caetité 1814.

192. APEB. Capitão Antonio Rodrigues Martins dos Santos 08/3482/38 . Jacobina 1810.

193. APEB. Alferes Francisco Pereira da Silva 09/3702/01 Cachoeira 1795.

194. APEB. José Antonio de Farias Lima 08/3415/01 Jeremoabo 1792.

195. APEB. Florinda da Costa 07/3042/17 Joazeiro 1808.

196. APEB. Maria martins da Encarnação 07/3182/14 Juazeiro 1797

197. APEB. Valentim Rodrigues Teixeira 08/3482/12 Jacobina 1795.

198. APEB. Antonio Ferreira Silva 04/1462a / 1931a/01 Joazeiro 1771.
} 
Paulino Pereira e Rosa Barbosa, ${ }^{199}$ Raimunda Maria e Antonio Pereira Pinto. Interessante observar a inexistência de menções às galináceas, certamente consumidas com frequência pelos sertanejos, mas em nenhum momento arroladas.

Outro animal que não aparece nos inventários, pelo evidente fato de não ser configurado como uma mercadoria mas que certamente abundava nas fazendas sertanejas eram os cachorros. Dentre os documentos compulsados há pelo menos duas referências aos cães. Uma delas é o processo crime aberto na Vila de Água Fria em 1771, citado logo no início do presente capítulo. Um dos acusados de roubar gado pelas estradas que passavam pela freguesia de São José das Itapororocas, Manoel cabra, andava sempre acompanhado de dois cachorros bravos. Mais três cães e uma cadela bons de caça foram citados por Antonio Gomes Ferrão Castelo Branco na descrição de seu escravo vaqueiro fugido. O negro costumava andar pelos sertões guiando boiadas, levando dinheiro e correspondência, sempre montado em seu cavalo e acompanhado pelos animais. ${ }^{200}$ Os cachorros eram comuns nas fazendas de gado. Corriam atrás do rebanho, acostumados a morder o calcanhar das reses para fazer com que se movimentassem. Como pastores ou caçadores, sempre foram lembrados como bons animais para auxiliar na vigilância sobre a propriedade. O latido anunciava a chegada de alguém ou a presença de algum animal que representasse perigo.

Nem só de pecuária viveram os sertanejos. A Fazenda Olhos D'Água, pertencente ao capitão José Antonio dos Santos, localizada no lugar chamado Muguengue era um exemplo de propriedade dedicada a produção de diversas mercadorias. Nas cinco léguas de comprido e três léguas de fundo, próximo a nascente do Rio de São João e ao Riacho Seco, havia inicialmente 400 cabeças de gado em seus pastos, 16 escravos e possuía três arrobas de algodão, roças de mandioca e vinte alqueres de feijão. Além do paiol onde possivelmente estocava os produtos agrícolas, havia na propriedade roda, ferro de secar e "desencaroçar" algodão.201

O rico comerciante e criador de gado Antonio José Viera Araújo, morador na Passagem do Juazeiro, também tinha investimentos em algodão. $\mathrm{Na}$ fazenda Tapera, no sertão pernambucano de Cabrobó, além das centenas de cabeças de gado vaccum e cavalares, possuía um banco com duas moendas de "desencaroçar" algodão, além de mais roças cujo produto cultivado não foi especificado. ${ }^{202}$ No inventário de Maria Bernarda de Jesus, falecida em 1796 na fazenda das Lajes em Caetité , aparece dados sobre a produção de algodão na fazenda das Quebradas, "terras foreiras a casa do Ilustríssimo Manoel de Saldanha", Casa da Ponte, além da criação dos bovinos. ${ }^{203}$

\footnotetext{
199. APEB. Paulino Pereira e Rosa Barbosa 08/3406/08

200. Antonio Gomes Ferrão Castelo Branco. Borrador em que lanço todas as cartas que escrevo, principiado em agosto de 1742, estando na Babia. São Paulo, Coleção Mindlin. Transcrito por Rosana Gonçalves sob orientação da Profa Dra Mary Del Priore e gentilmente cedido pelo Prof. Dr. Istvan Jancsó.

201. APEB. Maria Teresa do Bonfim 02/566/1018/02 Caetité 1814.

202. APEB. Antonio José Viera Araujo 08/3359/01 Joazeiro 1806.

203. APEB. Maria Bernarda de Jesus 02/578/1030/03 Caetité 1796.
} 
No sítio do Brejo do Cercado, localizado no Arraial de Santo Antonio da Barra na Vila de Nossa Senhora do Livramento das Minas do Rio de Contas, morava o casal Manoel Vaz da Costa e Maria Vitoria Conceição e mais três escravos de "campo e roça". Nas terras do casal, havia um engenho de moer cana descoberto, além de uma roda de ralar mandioca. ${ }^{204} \mathrm{O}$ sargento mor José de Pinna também possuía um engenho no sertão da vila de Urubu. ${ }^{205}$ Pascoal Correia de Souza, morador no sertão do Carinhanha contava uma roda d'água de ralar mandioca, 206 assim como Antonio Francisco Sacramento de Lacerda e Pedro José de Souza que também tinham entre seus bens uma casa de farinha e Valentim Rodrigues Teixeira dono de "um casa de farinha coberta de palha com sua roda de moer mandioca e prensa e um coxe".

Mesmo para as unidades produtivas dedicadas majoritariamente à criação do gado vaccum, somente algumas avaliações transcreviam detalhes sobre a propriedade e local em que o rebanho ficava pastando. Por exemplo, para algumas fazendas há descrição detalha das currais existentes na propriedade. Feitos de pau à pique ou coivara, cobertos de telha ${ }^{207}$ ou palha, alguns contavam inclusive com chiqueiro de bezerros ${ }^{208}$. Algumas também possuíam coxo, local em que ficava armazenado água ou algum tipo de ração ou alimento dado aos animais. Dependendo da fazenda, os chiqueiros e coxos eram sempre mencionados no plural como no caso da fazenda das Quebradas em que há referência a dois currais de pau a pique com "chiqueiros de amansar". Próximo aos currais estava a senzala.

Poucas foram as referências encontradas nos inventários compulsados sobre este tipo de moradia exclusiva dos escravos, comum às unidades produtivas agrícolas, porém pouco citadas para as fazendas dedicadas à pecuária. Os três exemplos de referência às senzalas como espaço de moradia dos cativos reforça a ideia: todas eram unidades produtivas mistas, em que a produção das reses era compartilhada com a produção e beneficiamento de algodão ou tabaco.

$\mathrm{Na}$ fazenda Rio Seco na Freguesia de Santana do Camisão (quarenta e quatro léguas distante da vila da Cachoeira), o Alferes Francisco Pereira da Silva possuía quatro senzalas de palha. Certamente, a maior parte dos escravos da propriedade trabalhavam no cultivo e benfeitoria do fumo plantado na fazenda, repleta de acessórios e casa de fumo, visto o trabalho de vaqueiro e feitor ser executado por homens livres a quem os herdeiros deviam os salários. $^{209}$ O Capitão-mor Gonçalo Cerqueira de Couto também possuía fazendas de gado nas freguesias de São Gonçalo dos Campos e Santana do Camisão. Em uma delas, a fazenda do Carro Quebrado, havia não só gado

\footnotetext{
204. APEB. Manoel Vaz da Costa 02/583/1035/06 Caetité 1807.

205. APEB. Juiz Ordinário de Vila de Santo Antonio do Urubu (05/11/1762) Doc. 03

206. APEB. Pascoal Correia de Souza 04/1454/1923/01 Carinhanha 1829.

207. APEB. José Antonio de Farias Lima 08/3415/01 Jeremoabo 1792.

208. APEB. Capitão Antonio Rodrigues Martins dos Santos 08/3482/38. Jacobina 1810.

209. APEB. Alferes Francisco Pereira da Silva 09/3702/01 Cachoeira 1795.
} 
vaccum, como também uma casa de palha de fabricar tabaco e duas senzalas e uma cerca avaliada em $10 \$ 000.210$

De fato, em todos os inventários analisados é possível encontrar referência a escravos trabalhadores e moradores das unidades produtivas sertanejas. Nas fazendas de criação de gado o número de cativos tendia a ser bem reduzido, variando conforme o nível de produção, o tamanho da propriedade e a existência ou não de outras atividades econômicas que demandassem o serviço dos homens, mulheres e crianças escravizadas. Todas elas moravam em casas pequenas feitas certamente em condições precárias. Não é possível saber se as moradias eram divididas por unidades familiares ou se todos os cativos das fazendas costumavam partilhar o mesmo pouso. A tendência da historiografia atual é pensar na formação de núcleos familiares, constituição de casais e laços de parentesco entre a comunidade escravizada. O estímulo vinha inclusive dos fazendeiros e da Igreja que viam na formação de famílias um modo de controle social, dificultando fugas individuais, além de solicitar maior estabilidade dos cativos que talvez pensassem muito mais antes de cometerem alguns deslizes. ${ }^{211}$

Para o caso das fazendas de gado dos sertões baianos, é possível garantir que, mesmo diante da reprodução social das hierarquias impostas por fatores tais como cor, condição jurídica e origem, a situação dos homens escravizados (quando exerciam o ofício altamente especializado de vaqueiro) tendia a ser marcada pelo livre deslocamento espacial, situação muitas vezes oposta aos inúmeros homens e mulheres, submetidos ao controle dos feitores e limitados a percorrer somente os arredores da fazenda em dias específicos. Esta mesma amplitude e maior maleabilidade na condição de cativo foi observada pela historiadora Gabriela Amorim Nogueira na dissertação de mestrado "Viver por si". Analisando o cotidiano da população escrava e forra do sertão de cima do Rio São Francisco, próximo a Bom Jesus da Lapa e a freguesia de Santo Antonio do Urubu de Cima, percebeu os modos de sociabilidade e autonomia da população vinculada a condição de cativeiro. ${ }^{212}$

Várias são as referências aos escravos vaqueiros acostumados a cuidar de unidades produtivas inteiras e conduzir boiadas e quantias avultadas de dinheiro para seus senhores. Para o caso do lide cotidiano nas fazendas, é difícil saber através dos inventários post-mortem quantos eram os escravos vaqueiros responsáveis por toda a produção, devido não constar neste tipo de documentação informações sobre a existência de outros trabalhadores livres dos currais, exceto nos casos em que o inventariado deixou alguma dívida por pagamento de salário. Ora, se há uma quantidade significativa de referência a escravos vaqueiros percorrendo por conta própria os sertões baianos conduzindo boiadas, levando correspondências, entregando dinheiro de contado ( atividade muito mais arriscada e requeredora de confiança por parte

210. APEB. Capitão mor Gonçalo Cerqueira de Couto 02/703/1164/04 Cachoeira 1789.

211. Esta é a hipótese central da dissertação de mestrado elaborada por Antonio Roberto Alves Vieira. Família escrava e pecuária. Revisão historiográfica e perspectivas de pesquisas. USP, São Paulo, 2011.

212. Gabriela Amorim Nogueira. "Viver por si", viver pelos seus: família e comunidades de escravos e forros no "certam de Sima do Sam Francisco" (1730-1790). UNEB, Santo Antonio de Jesus, 2011. . 
do dono) é razoável pensar que algumas unidades produtivas também fossem deixadas totalmente aos cuidados dos vaqueiros escravizados.

No livro de Luiz Mott "Inquisição e Sociedade" há referência a alguns dos processos inquisitoriais mais interessantes abertos pelo Santo Ofício contra moradores da capitania da Bahia do século XVIII. Dentre eles aparece a acusação feita contra quatro moradores do sertão de Jacobina na década de 1740 por perambularem pelas estradas carregando consigo patuás com oração de São Cipriano, pedaços de hóstia consagrada e mandingas para evitar os perigos e as constantes ameaças e assaltos existentes nos caminhos. ${ }^{213}$

Antonio Gomes Ferrão Castelo Branco, senhor de engenho e das fazendas de gado que compunham o morgado do Porto da Folha no sertão do Lagarto, escreveu em outubro de 1753 uma carta sobre a fuga de seu escravo vaqueiro de confiança, Damaso Gomes da Cruz. O cativo teria fugido levando consigo uma cavalo de estribaria, três cães e uma cadela bons para caça, além de gado vaccum.

O mulato se chama Damaso Gomes da Cruz; de idade de 40 para 50 anos [...] filho de branco com preta [...] pé e perna sem tortura; um lobinho em uma coxa pela parte de dentro que do andar à cavalo o tem machucado em forma de pasta pendurada; sabe ler, escrever e contar, não bem; toca viola peças do sertão e dança as mesmas peças; bebe fumo; toma tabaco; conta histórias do Trancoso; aplica algumas mesinhas caseiras; é doente de hemorroidas; entende de barbeiro, seleiro, sapateiro, curtir peles e fazer queijos: é bom vaqueiro; conversado; tem astúcia e disfarce de modo que está tão longe de ser fardeiro que antes quem o não conhece, parece um mulato de propósito consigo. Ninguém se fie nas suas promessas primorosas; tem lábia em tr.os. [...]Andou algum dia para Jaguaribe e Piaguhy cobrando gados para seu senhor: porém bom é buscar-se por mais partes. ${ }^{214}$

Há muitas referências nos "Livros de Registro de Entrada de Gado" na feira de Capuame de escravos condutores que eram os grandes responsáveis por encaminhar as reses de seus senhores ou de outrem. Apesar de representarem somente $7,1 \%$ do total de entradas para o período, a própria existência de escravos responsáveis por um trabalho requeredor de tanta confiança e habilidade já trás consigo o questionamento sobre as condições de cativeiro da América Portuguesa. Dentre os condutores que passavam com certa frequência por Capuame estavam os escravos pertencentes aos herdeiros da Casa da Ponte tais como os condutores Ignácio e Antonio do Vale, o condutor Pedro Nunes da Silva, Antonio da Silva, Adriano de Souza do Sertão do Tucano, o escravo condutor Luis Pereira do Sertão da Jacobina . Há também referência a Amaro, escravo de Lourenço Barboza do Sertão do Morro; os escravos Gonçalo e Felix Gonçalves pertencentes ao Sargento Mor Luis de Almeida do Sertão do Itapicuru; Bernardo e Felício, escravos de Antonio Pereira do Sertão do Piauí; Ilario do Sertão de Curassá; Manoel,

213. Luiz Mott. "Quatro mandigueiros do sertão da Jacobina nas garras da Inquisição". Inquisição e Sociedade. Salvador, 2010, p. 121-169.

214. Antonio Gomes Ferrão Castelo Branco. Borrador em que lanço todas as cartas que escrevo, principiado em agosto de 1742, estando na Babia. São Paulo, Coleção Mindlin. Transcrito por Rosana Gonçalves sob orientação da Profa Dra Mary Del Priore e gentilmente cedido pelo Prof. Dr. Istuan Jancsó. 
escravo do Capitão Pedro Caetano do Sertão do Tocôs; Roque, escravo de Jozé Ferreira do Sertão do Piauí; Felipe Roiz', escravo de Floriano do Rego do Sertão do Piauí; Manoel, escravo de Jozé Pires de Carvalho do Sertão do Rio de São Francisco; Jozé, escravo das religiosas da Soledade do Sertão do Itapicuru. ${ }^{215}$ Evidente que a verificação da existência de escravos vaqueiros perambulando livremente pelos sertões não devem propor de imediato a interpretação de uma relação mais "suave" de cativeiro.

Mesmo com a presença de vaqueiros e campeiros escravos, também era comum em algumas propriedades o emprego de vaqueiros livres. No inventário de Thomé Lançarote, membro da família Rocha Pitta, é possível perceber que todas as suas fazendas de gado espalhadas nos sertões pertencentes a Capitania do Pernambuco estavam sobre a administração de vaqueiros livres. Devido a distância das propriedades em relação à Comarca de Salvador - onde o inventário foi aberto - cada uma das fazendas foi avaliada pelo seu respectivo vaqueiro. $\mathrm{O}$ mais curioso do documento é o cuidado com que os currais foram descritos, havendo inclusive uma distinção interna ao rebanho. Se na maior parte dos inventários, os animais aparecem com a genérica descrição "gado vaccum de toda a sorte", sendo calculado um valor médio por cabeça de gado, no inventário post-mortem de Thomé Lançarote foram especificados os garrotes, novilhos, bois, vacas, vacas parideiras. Tudo isso porque cada um deles equivalia a uma valor distinto e evidentemente não podiam ser tratados da mesma maneira por um exíguo conhecedor do assunto: o vaqueiro. ${ }^{216}$

No inventário de Thomé Lançarote não há especificação sobre o sistema de partilha, mas em outros documentos aparece os desenhos e anotações que representam o modo de pagamento dos vaqueiros pelo trabalho realizado. Segundo a historiografia, a remuneração era feita através do sistema de quarta ou quinta. Ou seja, de cada quatro ou cinco crias nascidas no ano, uma cabia ao vaqueiro, conforme o acordo firmado com o dono do gado. ${ }^{217}$

Apesar do sistema de "sorte" (outro nome dado ao modo de remuneração dos vaqueiros, visto a escolha das crias que lhe cabiam ser feito através de uma espécie de jogo de sorte) ter sido interpretado por muitos estudiosos como uma brecha no regime de exploração do trabalho, permitindo em tese uma acumulação de pecúlio por parte dos escravos ou, no caso dos homens livres, uma possibilidade de montarem por conta própria o seu rebanho e tornarem-se facilmente donos de fazenda, esta certamente não era uma realidade para todos os sertanejos.

Entretanto, não há como negar que alguns vaqueiros possuíam rebanho próprio, chegando mesmo a montar a sua própria fazenda de gado, como nos faz crer o relato de Manoel Lopes, morador na Serra Limpa, freguesia de São Miguel, nas Alagoas. Foi vaqueiro do Capitão Bernardo Vieira de Mello,

215. AMS. "Livro de Registro de Entrada de Gado" da feira de Capuame (1784-1789)

216. APEB. Thomé Lançarote Pitta. Capital 03/1035/1504/01.

217. Lycurgo dos Santos Filho. Uma comunidade rural no Brasil Antigo (aspectos da vida patriarcal na sertão da Babia nos séculos XVIII e XIX). São Paulo, 1956 , p. 211. 
“porém já hoje [ no ano de 1732] está com sua fazenda". ${ }^{218}$ É possível também pensar que a viabilidade de constituir o próprio rebanho fosse mais fácil nas primeiras décadas do século XVIII quando ainda havia uma quantidade grande de terras não doadas em forma de sesmarias ou não ocupadas por fazendeiros e posseiros. Mal comparando, talvez seja possível pensar em um paralelo com os caixeiros viajantes. Membros mais jovens de famílias de negociantes, assumiam primeiramente uma posição menor nos trâmites comerciais, mas logo eram incentivados para seguir os seus próprios negócios. ${ }^{219}$ De acordo com as cartas de sesmarias e as múltiplas referências às terras doadas as mesmas pessoas, talvez somente uma família não desse conta sozinha de ocupar as muitas léguas destinadas a montar as fazendas de gado vaccum. Era comum as terras serem repartidas entre os membros mais distantes das famílias ou até mesmo serem arrendadas para outros possíveis ocupantes interessados em se estabelecer nas terras sertanejas. Talvez daí resulte que um vaqueiro pudesse começar a sua empreitada subordinado inicialmente ao sesmeiro e depois conseguisse montar a própria fazenda arrendando um pedaço de terra. Pelo menos para o início do século. Na Fazenda do Brejo Seco, caso convenientemente sempre lembrado pela historiografia, o vaqueiro também era um homem aparentado ao dono do rebanho, conseguindo posteriormente montar a sua própria unidade produtiva. ${ }^{220}$ Sendo assim, a relação entre o vaqueiro e o dono do rebanho certamente era fundamental para determinar a sorte do trabalhador.

É possível perceber que na hierarquia social consolidada nos sertões baianos pari passu ao avanço do processo de territorialização que trouxe consigo uma sociedade pautada crescentemente por relações sociais baseadas na produção pecuarista e mediada majoritariamente pela mercadoria gado, o topo da escala cabia aos grandes proprietários de terras e homens de patentes. Os herdeiros direto dos primeiros "práticos dos sertões", responsáveis pela expansão das fronteiras do domínio português passaram a controlar amplamente a terra e o trabalho, através do exercício de seu poder baseado no uso indiscriminado da violência direta e indireta. A onipresença de alguns homens da elite sertaneja é perceptível através da análise dos documentos que ainda restam sobre os sertões baianos. O juiz de paz, juiz dos órfãos, escrivão, entre outros, comumente possuíam patentes e sobrenomes bem conhecidos, além de pertencerem ao reduzido grupo dos homens mais ricos da região. Não raras vezes acumulavam mais de um cargo público, eram coletores de impostos, além de serem ligados diretamente com a produção e comércio de

218. AHU. Caixa 1 doc. 8-9. Carta do Conde de Sabugosa, remettendo a D. João V os documentos seguintes. Bahia, 29 de maio de 1734. Carta do Coronel Francisco Alves Camello , morador nos Campos da Comarca de Alagoas, para o capitão Bernardo Vieira de Mello, morador no Engenho de Pindoba, freguesia de Ipojuca, relatando uns acontecimentos extraordinários e de pura phantasia, que Manuel Lopes Cabral, morador na Serra Limpa, dizia terem sido observados por suas filhas. S. D. (1734).Tem anexa a declaração feita por M. Lopes Cabral e escripta pelo Alferes Manuel Abreu de Lima.

219. Junia Furtado. Homens de negócio: a interiorização da metrópole e do comércio nas Minas setecentistas. São Paulo, 1999.

220. Lycurgo do Santos Filho. op. cit. 
gado. Não é de se surpreender que também figurassem como os maiores credores da população livre e pobre da área em que atuavam.

\subsection{Sociabilidade sertaneja}

Assim como os escravos vaqueiros que trabalhavam de tempos em tempos como condutores das boiadas em direção à feira de Capuame, a maior parte dos sertanejos eram verdadeiros homens dos caminhos. ${ }^{221}$ Não só pela própria característica de ocupação da região, cuja itinerância era a marca chave do movimento de abertura de fronteiras e frente de expansão da pecuária e dos domínios portugueses. O constante deslocamento é um dos traços comuns a todas as atividades pastoris desde a Antiguidade. Muitas das comunidades nômades espalhadas pelo globo tinham como atividade primordial não o sedentarismo requerido pela agricultura, mas o constante vai e vem imposto pela atividade criatória. Seja pela busca de novos pastos em um mundo cujas fronteiras administrativas dos Estados e das propriedades privadas ainda não estavam definidas como elemento limitador do movimento populacional, seja pelo moderno e generalizado encaminhamento dos rebanhos (transformados em mera mercadoria) aos centros consumidores e aos polos de atração de todos os recursos e cabedais tais como as florescentes cidades.

No caso dos sertões baianos, marcado pela produção pecuarista extensiva, não podia deixar de ser diferente. Primeiramente, vale destacar que os primeiros fazendeiros eram por excelência homens dos caminhos: aventureiros, os sertanistas eram aqueles que (independente de juízo de valor) tinham ganância e ambição suficiente para enfrentar o desconhecido, se embrenhar nos matos e viabilizar (bem ao gosto das diretrizes impostas pela metrópole) a exploração econômica de terras tão distantes com o auxílio de índios e africanos escravizados. Faziam o reconhecimento do novo território, deparavam-se e interagiam (ao seu modo) com os indígenas que esbarravam pelo interior. Inclusive, é importante lembrar que os primeiros caminhos percorridos pelos colonizadores tratavam-se de picadas e atalhos traçados e frequentados primeiramente por gerações de comunidades indígenas, também afeitas ao nomadismo. ${ }^{222}$ Com elas, os sertanistas aprenderam a localizar os rios, os animais e plantas comestíveis e fortaleceram a prática de orientação pelo sol e as estrelas já exercida na travessia do Atlântico. ${ }^{223}$ Aprenderam a preparar a carne de moquem, técnica usada inicialmente para o preparo do peixe, consistindo em defumá-la para mantê-la conservada por mais tempo, depois substituída pelo processo de salga para produção de carne-seca ou carne de sol. ${ }^{224}$

\footnotetext{
221. Isnara Pereira Ivo. op. cit.

222. Sérgio Buarque de Holanda. Caminhos e fronteiras. São Paulo, 2008.

223. Jaime Cortesão. Raposo Tavares e a Formação Territorial do Brasil. Lisboa, 1966.

224. DH. "Regimento que levou o Capitão Bartholomeu Aires, que foi por Cabo de quatro Companhias fazer guerra ao Gentio do Sertão ." p. 64 vol. 4
} 
Não fosse a interação com os indígenas e os conhecimentos apropriados em uma lógica totalmente desproporcional ( condição básica da dominação), os primeiros sertanistas de certo não atingiriam os objetivos almejados. ${ }^{225} \mathrm{Com}$ o auxílio de guias e línguas, acompanharam o constante deslocamento já praticado pelos indígenas estabelecidos no Novo Mundo. Interessante notar que depois do esquadrinhamento dos sertões e a menor dependência que tinham em relação aos serviços prestados (compulsoriamente ou não) pelos autóctones, uma das primeiras diretrizes da Coroa era promover o mais rápido possível a sedentarização das tribos pacificadas.

Em 1662, foi entregue ao Capitão Manuel da Costa uma determinada quantidade de gado que deveria ser encaminhada para as terras dos índios estabelecidos na Serra do Gayrarú. Esta concessão fazia parte da política de "pacificação", depois de muita negociação, após inúmeros conflitos na região interiorana do Recôncavo Baiano. Com o intuito de que os indígenas dos sertões não descessem para as regiões produtoras de açúcar, fazia-se necessário mantê-los "contentes" e por isso prometeram aos principais desta aldeia da Serra do Gayarú bois para montarem currais, além das cavalgaduras que pediram, "[as]segurando sua permanência por meio de terem bens que os obrigue a não usar de sua natural inconstância."226 Mantê-los ligados a um espaço determinado através da sedentarização necessária para a produção agropecuária era uma das estratégias de controle sobre esta população com quem muitas vezes a paz negociada mostrava-se como única alternativa para garantir a sobrevivência.

Mesmo depois de consolidadas as fazendas de gado vaccum, o deslocamento dos sertanejos continuava: rumo aos núcleos populacionais mais movimentados, como as Minas Gerais ou o litoral baiano, lá iam criadores e condutores trocar o rebanho pelo equivalente universal (ouro), por moedas, outras mercadorias ou por crédito. Percorrendo longas distâncias até chegar à feira de Capuame, a vida sertaneja continuava a se reproduzir nas estradas e caminhos setecentistas. Até as próprias vilas e sedes de fazendas vez por outra mudavam de lugar. A antiga vila de Nossa Senhora do Livramento das Minas do Rio de Contas, antes localizada onde atualmente fica Vila Velha, (na margem esquerda do Rio Brumado) foi transferida em 1745 para um sítio mais alto, na região mais elevada da Serra das Almas $^{227}$ devido a uma série de epidemias que afetou parte da população. ${ }^{228} \mathrm{Na}$ ocasião em que as Minas de Jacobina foi elevada à vila, no ano de 1724, também houve um deslocamento da população para outro sítio. A medida, tomada pelo coronel Pedro Barbosa Leal, não foi vista com bons olhos pelo Coronel Garcia D'Ávila ( a quem a fundação da vila foi delegada, mas por motivos de saúde, teve de deixar a

225. Para pensar a mestiçagem e o sistema de colonização de modo crítico e como um processo assimétrico, ver: Serge Gruzinski. O pensamento mestiço. São Paulo, 2001.

226. DH. "Ordem que levou o Capitão Manuel da Costa indo a entregar o gado que se prometteu aos Índios da Serra do Gayrarú. ” 2 de junho de 1665. vol. 5 p. 408.

227. Maria Aparecida Silva de Sousa. A conquista do sertão da Ressaca: povoamento e posse da terra no interior da Babia. Vitória da Conquista, 2001, p. 30.

228. Lycurgo dos Santos Filho. op. cit. p. 5. 
tarefa para seu rival). O episódio causou grande desconforto e demonstração de poder do descendente da Casa da Torre, deixando evidente a rivalidade entre os dois afamados sertanistas, possivelmente inimigos de longa data. ${ }^{229}$ As sedes de fazendas, por motivos variados também sofriam alteração de sua localização, mas nenhuma mereceu registro e informações documentais nos moldes das vilas mineradoras do interior da capitania da Bahia, por motivos evidentes. Os aldeamentos indígenas, administrados por padres ou pelos donos das terras onde estavam fixadas, tinham maior instabilidade ainda: bastava a necessidade de construir um novo pasto, abrir ou mudar o curso de uma estrada para rapidamente os índios terem de "levantar acampamento" e mudarem para outras paragens mais ou menos próximas da localização anterior. Esse foi o caso e um dos motivos das brigas entre Pedro Barbosa Leal e Garcia D'Ávila no episódio de fundação da vila de Jacobina. Não só a nova vila estaria situada nas terras da Casa da Torre, resultando na diminuição da propriedade, como também requeria o deslocamento dos índios da missão de Nossa Senhora das Neves, desdobrando-se em reclamações do vigário da Igreja Matriz de Santo Antonio de Jacobina. A aldeia Jagoarari, localizada na Barra do Salitre, próximo ao rio São Francisco, foi deslocada, resultando na fuga de muitos índios, dentre eles o capitão mor da aldeia administrada por Garcia D'Ávila. Por lá passava, segundo o relato, a estrada que vinha do Piauí em direção à Bahia para condução das boiadas. Pedro Barbosa Leal ordenou o fechamento da antiga estrada e sua remoção para que a nova via passasse por dentro da vila de Jacobina, " com rodeio de dois ou três dias de viagem". 230

Acostumados a se embrenhar nos matos também eram os homens dedicados à mineração e principalmente ao garimpo. $O$ trabalho de prospecção exigia muito caminhar, paciência e escavação. Passando de serra em serra, observando bem os aluviões e bateias à procura de pontos possivelmente exploráveis, paravam em lugares de difícil acesso, como por exemplo a Chapada Diamantina, entre os distritos de Rio de Contas e Jacobina, localizada na Serra do Sincorá, só efetivamente explorado no século XIX. ${ }^{231}$

Afeitos à itinerância também eram os mascates, tropeiros e todo o tipo de negociante e viandante que não só tinha a coragem de largar uma vida inteira no reino de Portugal (onde possivelmente levavam uma vida nada luxuosa quando não era degredados, evidentemente), mobilizados pelo trabalho e pelo sonho de fazerem fortuna. Embarcavam para uma colônia na América, onde ainda resolviam adentrar o território e percorrer centena de léguas firmando contratos, vendendo mercadorias, negociando escravos, explorando o trabalho dos não-brancos. ${ }^{232}$

229. AHU. c. 20 doc. 1770. "Requerimento do coronel Garcia de Ávila pereira ao rei solicitando que mande examinar a desordem causada pelo coronel Pedro Barbosa Leal por ocasião da fundação de uma vila no sítio da lagoa. 16 de outubro de 1724. Documentos Avulsos.

230. Idem.

231. Carlos Almeida Toledo. A região das Lavras Baianas. USP, São Paulo, 2008, p. 40.

232. Ver: Isnara Pereira Ivo, op. cit.; Erivaldo Fagundes Neves, op. cit. 
Em um mundo dominado pelos brancos (ou quase brancos), ser negro significava viver marcado por um estigma social carregado cotidianamente pelos libertos cuja cor os remetia de alguma maneira ao passado no cativeiro. Muitos homens e mulheres conquistaram a liberdade no decorrer do século XVIII. E já que muitas vezes liberdade era sinônimo de não-trabalho, ou pelo menos trabalho não-alienado, alguns tentaram a sorte viajando para o interior como tropeiros e vaqueiros, exercendo ofícios que contassem com o mínimo de vigilância possível. ${ }^{233}$ Todavia, a livre circulação da população liberta incomodava os membros brancos da sociedade, chegando ao ponto de pedirem ao rei a edição de uma Ordem Régia impedindo as viagens executadas por comerciantes mulatos e negros. ${ }^{234}$ Ao que tudo indica, a solicitação não foi posta em prática, continuando a vagar pelos sertões baianos todo o tipo de gente indesejada que causava pânico à elite branca. Dentre eles estavam os ciganos.

Não é a toa que uma hora ou outra o historiador dedicado ao período colonial esbarra, em meio aos documentos compulsados, com informações sobre a existência de ciganos circulando pela América Portuguesa. ${ }^{235}$ Ainda faltam pesquisas dedicadas exclusivamente a presença de povos marcadamente itinerantes pelas estradas e caminhos interioranos, especialmente pelos sertões baianos. Todavia, devido a quantidade de degredados e as inúmeras reclamações, tudo leva a crer que a presença cigana foi uma constante. Segundo José D' Oliveira China, a América Portuguesa foi um dos destinos principais dos ciganos que vieram para o Novo Mundo. Uma lei do Reino de Portugal, do ano de 1708, proibia a existência de pessoas que andassem com roupas e "geringonças" de ciganos. Os acusados não precisavam ter cometido qualquer outro delito. Em geral, sofriam a pena de açoite e degredo as galés ou eram enviados ao Brasil. ${ }^{236}$ A lei de 11 de abril de 1718 fala sobre a proibição de que eles usassem sua língua e as ensinem aos filhos. ${ }^{237}$

Os ciganos eram vistos com desconfiança e sempre acusados por crimes de roubo, especialmente de cavalos, visto a familiaridade que tinham com este tipo de animal sendo mais de uma vez retratados como comerciantes de gado cavalar e escravos. Eram também identificados como infratores que andavam pelas estradas portando armas de fogo. ${ }^{238}$

Pelas bandas do arraial do Tijuco (Minas Gerais), em 1730, começaram a aparecer denúncias de crimes cometidos por grupos e bandos que agiam nas estradas. Dentre os acusados estavam os ciganos que foram colocados no

\footnotetext{
233. Russell-Wood. Escravos e libertos no Brasil colonial.[1982]. Rio de Janeiro, 2005, p. 63.

234. APEB. "Ordens régias", Cartas dos vereadores de Mariana ao rei, 5 de maio de 1755, vol. 54, fl. 99.

235. Erivaldo Fagundes Neves. "Mouros, judeus e ciganos: origens portuguesas de famílias do Alto Sertão da Bahia”. Erivaldo Fagundes Neves (org.). Sertões da Bahia: formação social, desenvolvimento econômico, evolução política e diversidade cultural. Salvador, 2011. p. 63 e segs.

236. José D'Oliveira China. Ciganos do Brasil: subsídios históricos, ethnographicos e linguísticos. São Paulo, 1936, p. 59 .

237. Idem, p. 62.

238. Idem, p. 59.
} 
mesmo patamar dos vagabundos, desocupados e quilombolas. ${ }^{239}$ As mulheres ciganas também recebiam atenção especial das autoridades coloniais pelo seu modo escandaloso de vida, sendo recomendado em alvará de 1760, manterem vigilância sobre estas mulheres para que se comportassem e permanecessem recolhidas como as demais mulheres da colônia, ${ }^{240}$ indicando possivelmente $\mathrm{O}$ costume de estarem sempre perambulando pelas ruas, muitas vezes desacompanhadas de homens.

Assim como os indígenas, os ciganos praticavam um tipo de itinerância que não condizia com aquela desejada pela Coroa. Diretrizes elaboradas pelo poder central orientavam os governantes da América Portuguesa a cuidarem para que os ciganos tomassem "vida civil". Tinham costume de deixar suas casas em bairros apartados para fazerem trocas e vendas pelos sertões. A carta de 1 de agosto de 1761, mandava ordens a todos os capitães mores, juízes de fora e ordinários para prendê-los e obrigá-los a uma residência fixa, não os deixando viver nos matos. Alguns dos ciganos mais velhos pediram autorização para arrendar fazendas onde teriam lavoura. Só seria concedido o direito caso trouxessem em vida regrada todos os membros da família. Os jovens e pequenos deviam ser entregues a mestres que lhes ensinassem serviços mecânicos e os adultos deviam sentar praça,

“[...] de sorte que nunca estejam muito juntos em um mesmo presídio [...] Proibindose a todos poderem comerciar bestas e escravos e andarem em ranchos: que vivão em bairros separados[...] Que os velhos e casados e as mulheres se firmem em lojas de venda onde terão despacho e guia"241

Não interessava às autoridades régias o deslocamento que não fosse mobilizado pelo trabalho nas zonas de mineração ou pelo trabalho do comércio executado pelos cristãos quase brancos. Assim como os negros e mulatos indesejados como efetivadores das atividades mercantis, os ciganos também eram cada vez mais cerceados de andar em grupo pelos sertões baianos e atuarem em uma das atividades que desempenhavam historicamente em todos os cantos por onde passavam: o comércio. ${ }^{242}$

Os sertões baianos abrigavam a itinerância dos bandos de ladrões e assaltantes, perseguidos, fugitivos, degredados e desclassificados, para não falar dos flagelados e vítimas da seca do século XIX em diante. Constante deslocamento dos quilombolas e indígenas cada vez mais desterritorializados. Os quatro filhos do vaqueiro Manoel Lopes presenciaram um destes deslocamentos. Na região de Serra Limpa, próximo a fazenda onde moravam, na freguesia de São Miguel em Alagoas, viram o trânsito de "dois cavaleiros com mulheres em ancas, cabras delles e sua negra com um coco de prata ao pescoço e hua tapuya com uma canastra a cabeça e mais atrás algumas redes

\footnotetext{
239. João Dornas Filho . “Os ciganos em Minas Gerais”. RIHGMG, Rio de Janeiro, 1948. p.147-151.

240. APEB. Maço 175. Doc. 08. Bahia, 3 de junho de 1768 .

241. Carta de 1 de agosto de 1761. Doc. Transcrito na edição 31 dos Anais da Biblioteca Nacional do Rio de Janeiro, 1909. n. 5350 apud. Os ciganos do Brasil. p. 62.

242. Martin Fotta. The bankers of the backlands: financialisation and the Calon-Gypsies in Babia. University of London. 2012.
} 
com mombandas e gente dela com pagens todos armados e ocultando armas." As crianças chegaram a conversar com uma mulher que parou na beira da lagoa para lavar roupa. ${ }^{243}$

Romeiros e beatos seguidos por um sem-número de despossuídos vagavam pelos sertões de um lado para o outro sendo observados com apreensão pelas autoridades. Em outubro de 1733 foi enviado uma sequência de ordens ao Coronel Garcia D'Ávila Pereira para averiguar as notícias de que, segundo o governador de Pernambuco, havia passado para as partes do sertão das Alagoas um moço que se intitulava o "príncipe do Brasil"." "Vagando de um para outro distrito" tinha por companhia alguns negros, mulatos, mamelucos e outros criminosos, "procurando agregar sempre os índios das aldeias vizinhas". Chamado de aventureiro, as ordens de prisão foram expedidas para que ele fosse castigado pela ousadia e atrevimento. O medo era que os seus seguidores aumentassem ainda mais na medida em que só crescia o número de agregados por todos os sertões que perambulavam. Receberam notícias de que o perseguido havia passado das Alagoas para os Garanhuns do Urubu, seguido por muitos negros fugidos e índios, quando finalmente foi preso. $^{244}$

Caso tracemos a trajetória pessoal de muitos sertanejos dedicados à pecuária, é possível perceber que a itinerância foi uma constante na vida de muitas famílias. Seria possível, através de um única fonte documental comprovar tal hipótese. Os processos de desimpedimento matrimonial formam uma espécie de relatório sobre a inexistência de casamento anterior dos futuros cônjuges. Geralmente guardados nas Cúrias Metropolitanas, neles aparecem o local de nascimento e batizado do noivo, assim como as vilas e freguesias pelas quais passou e poderia ter contraído algum matrimônio não declarado. Ainda faz-se necessário uma pesquisa sobre o assunto utilizando maciçamente este interessante tipo documental para os sertões baianos. ${ }^{245}$

No decorrer do século XVIII é possível perceber um movimento geral de maior consolidação das famílias em um determinado território, por mais que o fluxo populacional continuasse aberto. Criação de vilas e freguesias formavam uma nova sociabilidade sertaneja, mesmo que ela fosse mais afeita às comunidades rurais, vinculadas a uma terra específica, girando muito em torno das fazendas de gado da região, ficando os centros de vilas e freguesias como pontos de encontro da vida religiosa, administrativa e muitas vezes comercial da localidade. Interessante reparar que de fato as primeiras vilas estabelecidas no interior da capitania da Bahia estavam diretamente vinculadas a descoberta de pontos de mineração no interior, provocando uma

\footnotetext{
243. AHU. Bahia. Caixa. 1 doc. 8-9. Carta do Conde de Sabugosa, remettendo a D. João V os documentos seguintes. Bahia, 29 de maio de 1734.

244. APEB. Carta do Governo (à várias autoridades) 1730-1734. Maço 151. "Carta do Governador do Pernambuco Jorge Dias de Carvalho", fl. 297; "Carta para Garcia Avila”, fl. 299; "Carta ao Coronel Garcia D Avila Pereira”, fl. 300.

245. Pesquisas utilizando os processos de dispensa matrimonial já foram feitos para outras regiões, tais como São Paulo, ver: Maria Aparecida de Menezes Borrego. A teia mercantil: Negócios e poderes em São Paulo Colonial (1711-1765). São Paulo, 2006.
} 
concentração populacional em torno da busca pelo ouro. Mesmo que momentaneamente, as raízes eram afixadas e o círculo de amizades e convívio eram cada vez mais marcados pela presença de vizinhos e conterrâneos.

\section{QUADRO 8: Vilas dos sertões baianos (século XVIII)}

\begin{tabular}{|l|l|}
\hline ANO & VILAS \\
\hline 1720 & Santo Antonio de Jacobina \\
\hline 1724 & SS Sacramento das Minas do Rio de Contas \\
\hline 1727 & Abadia \\
\hline 1727 & São João Batista da Água Fria \\
\hline 1727 & Itapicuru de Cima \\
\hline 1745 & Urubu \\
\hline 1752 & São Francisco das Chagas da Barra do Rio Grande \\
\hline 1758 & Nova de Abrantes \\
\hline 1758 & Nova de Soure \\
\hline 1758 & Nova de Pombal \\
\hline 1797 & Nova da Rainha \\
\hline 1801 & Inhambupe de Cima \\
\hline
\end{tabular}

Fonte: Evolução territorial e administrativa do Estado da Bahia: um breve histórico. Salvador, 2001.

Através da lista da "Companhia das Caatingas de que é capitão Francisco Manuel de Mattos" é possível perceber que em uma mesma unidade produtiva morava mais de uma família (família aqui adotada como categoria na acepção de conjunto estendido). ${ }^{246}$ Mesmo não constando a data e a localidade a que se resumia a companhia, é possível saber que se encontrava no sertão (devido ao adjetivo caatingas) distante cerca de dez léguas da vila a qual estava submetida. Dentre as profissões arroladas e ocupações frequentes dos habitantes aparece somente lavrador ou vaqueiro, denotando por fim tratar-se de uma região rural com a incidência de fazendas de gado. $\mathrm{Na}$ lista aparece o nome da unidade produtiva, os possíveis donos ( arrolados na primeira posição), os filhos, outros parentes, empregados ou moradores (mesmo que não apareça o grau de relação e parentesco, algumas pessoas não são referidas nem como agregados e nem escravos), seguidos pelos escravos e por último os agregados. Tanto homens quanto mulheres tem a idade e cor especificada. 
$\mathrm{Na}$ fazenda Bom Jardim, morava o casal de pardos Antônia Maria (40 anos) e João Correia Pais, vaqueiro de 60 anos. Possuíam seis filhos com idade entre 8 e 25 anos. Uma das filhas do casal chamava-se Clara Maria. Tinha 25 anos, possuía dois filhos e era casada com José Pereira, lavrador de 30 anos que aparece como agregado à família. $\mathrm{O}$ filho mais velho de Clara Maria tinha a mesma idade de seu irmão mais novo: oito anos. A fazenda contava com mais três casais de agregados com seus respectivos filhos. Todos pardos. Não havia nenhum escravo na unidade produtiva.

No sítio do Espinheiro também não faltavam agregados. Manuel de Souza e Ignácia moravam com três filhas e um genro ( considerado agregado). Romão Correia de Mattos e Clara Angélica tinham dois escravos. Não aparecem como agregados, mas são descritos em uma parte diferente, denotando talvez tratar-se de um outro núcleo familiar. Não é possível saber qual a relação mantida entre as duas famílias a não ser habitarem as mesmas terras. Francisco da Costa e Ana de Souza também aparecem como uma casal pertencente a um outro núcleo familiar mas sem a descrição de agregado. Será que Ana era irmã de Manuel de Souza? Difícil saber. No mesmo grupo em que estava Ana de Souza chama a atenção a quantidade de agregados: doze pessoas, sendo vários deles menores de idade. Fora as três filhas do viúvo e lavrador Manoel Francisco, mais nenhum dos pardos com idade entre onze e vinte anos aparecem com o nome dos pais. Pode ser que fossem filhos de algum parente próximo que faleceu e morava anteriormente no sítio. Ou talvez as crianças tivessem ficado sob responsabilidade de Ana de Souza.

O viúvo Firmino de Freitas também era agregado de Manuel de Souza e Ignácia. Possuía quatro escravas. O vaqueiro Antonio José ( 25 anos) e sua mulher Joana (22 anos) morava com dois filhos de idade entre 12 e 11 anos. Não eram agregados. Joana tivera filhos com 10 anos? Pelo o que faz crer o documento, sim. A não ser que fosse sua enteada, filha do pardo Antonio, nascida quando o vaqueiro tinha apenas 13 anos de idade. Era comum na sociedade colonial as mulheres terem filhos cedo, dando a luz logo após a primeira menstruação. ${ }^{247}$ Vitória, mulher de Caetano José também teve filhos nova. A coabitante do sítio bem povoado teve seu primeiro filho, Joaquim, com quinze anos.

Testemunhos levantados em processos crimes, dívidas arroladas nos inventários post-mortem também servem como exemplos concretos da proximidade e da redes de amizade, solidariedade e convivência firmadas pelos moradores dos sertões baianos. Nos documentos restantes torna-se possível perceber que a vizinhança tinha um papel importante para a estrutura das redes de sociabilidade firmadas entre a população local. Notícias circulavam entre os moradores e frequentadores das estradas; vivências e experiências eram compartilhadas; acontecimentos, comentados. Laços eram fortalecidos pelo regime de compadrio e dívidas contraídas com os membros mais

\footnotetext{
247. Miridan Knox Falci. "Mulheres do sertão nordestino." Mary Del Priori (org.) História das mulheres no Brasil. São Paulo, 2009, p. 268; Linda Lewin. "Some historical implications of kinship organization for family-based politics in the brazilian northeast". Comparative Studies in Society and History, v. 21, n. 2, april 1972. p. 284.
} 
abastados da comunidade. Mas certamente, por tratar-se de um espaço de constante trânsito, afeito ao deslocamento imposto pela própria lógica da pecuária que empurrava de tempos em tempos parte dos homens dedicados à produção para a itinerância experimentada nas estradas, a sociabilidade sertaneja não se resumia a localidade.

O armazém do rico comerciante e criador de gado vaccum e cavalar Antonio José Viera Araújo mostra-se como um bom exemplo. Era localizado bem na passagem do Juazeiro. Região movimentada, ponto de convergência de muitos caminhos e da famosa Estrada das Boiadas, passagem obrigatória para a travessia do rio São Francisco, onde desde o início do século XVIII precisavam pagar o direito de passagem Real a um contratador, ${ }^{248}$ servia como espaço de parada temporária dos condutores vindos do Piaú e outras regiões. O Armazém ficava no beco do Arruda e possuía variados produtos para serem comercializados: tecidos de todos os tipos, 45 cadernos de papel, 80 rosários de miçangas, noz moscada, enxofre, canela, alfazema, pedra úmida, pedra "lipes", pólvora, quatro pares de óculos, enxadas, mais de quinhentos canudos de cachimbos, tabaco, barris de vinho tinto, vinho branco, aguardente do reino, aguardente de cana, rapadura, farinha, dentre outros. A quantidade de mesas, cadeiras e louças não arroladas entre as "Fazendas secas do armazém" denotam ainda que lá possivelmente eram servidas refeições." Inclusive, é de se notar que dos treze escravos arrolados, nove eram mulheres. Seriam algumas delas cozinheiras? Além das três fazendas de gado vaccum, o comerciante possuía mais três casas nos arredores do armazém. Todas elas enormes. Será que algumas delas eram alugadas para viajantes?

Mas neste momento, o mais importante sobre o comércio executado por Antonio José Viera Araújo na Passagem do Juazeiro é perceber as informações constantes nos livros de nota em que estavam arroladas as dívidas dos fregueses. Dentre eles haviam muitos homens da Cidade de Oeiras (no Piauí) e moradores dos sertões próximos à Jacobina, Cabrobó (Pernambuco), Sento Sé, Salitre, Curassá. Seus credores estavam localizados na praça de Salvador e na vila de Penedo. Havia muitas descrições de devedores com os dizeres "moço de cavalaria", "homem andante", "homem volante", além de "Jozé Ignacio Rodrigues mestre alfaiate homem volante", "João de Masseno Pereira Sodré mestre ferreiro homem andante", demonstrando não só a itinerância de muitos de seus fregueses como a possibilidade de executarem seus ofícios prestando serviço por onde passavam ${ }^{249}$. Os moradores nas fazendas da região também foram citados com frequência. Aqui merece destaque a quantidade de mulheres que apareceram entre os clientes. Todas elas moradoras da região, mostrando a participação feminina no processo de compra de alimentos e artigos necessários para o lar, visto serem elas as grandes responsáveis direta por vários aspectos da reprodução interna das condições básicas de vida. Eram

248. AMS. Atas da Câmara (1718-1731). "Ata de 29 de agosto de 1729”, vol. 8, p. 161.

249. Segundo Luis Antonio Silva Araujo, o termo "volante" significava uma tipificação dos homens dedicados ao comércio, opondo-se a ideia de mercador fixo, como por exemplo um vendedor ou lojista. Os homens volantes podiam ser tanto tropeiros, comboieiros, mascates ou itinerantes de todo tipo. Luis Antonio Silva Araujo. Contratos e tributos nas Minas setecentistas: O estudo de um caso - João de Souza Lisboa (1745-1765). UFF, Niterói, 2002, p. 21. 
moradoras nas fazendas da Jeruminha, Pancaray, Manga, Barro Vermelho, das Lajes, Junco, Pedra D'Agua, Pico, entre outras. Inclusive a recorrência dos nomes das Fazendas são mais uma prova da quantidade de moradores existentes em cada uma destas unidades produtivas. ${ }^{250}$

Mesmo que as unidades produtivas não fossem tão próximas umas das outras, em muitas das paragens estudadas, as fazendas e sítios costumavam abrigar mais de uma família em suas terras. Seja como empregados, tarefeiros, agregados, condôminos que partilhavam a mesma terra por herança (mesmo que não houvesse uma divisão formalizada da propriedade) prevalecendo as áreas de uso comum, tais como os pastos. Principalmente no que dizia respeito à criação de gado, não compensava aos pequenos produtores dividir as terras, sendo muito mais útil compartilhar amplos pastos no qual arrebanhavam animais pertencentes a diferentes donos. Por isso o uso disseminado de ferros de marcar gado, comumente arrolado nos inventários post-mortem dos sertanejos dedicados à atividade criatória.

As Comunidades de Fundo de Pasto, como são chamados pelos antropólogos, tem por característica a posse e o uso comunal das terras, não havendo delimitação de propriedade individual. Possivelmente para fins do século XVIII e seguinte, fora as grandes unidades produtivas dos descendentes dos primeiros sesmeiros, que mantiveram vastos latifúndios e terras cercadas e vigiadas por seus empregados livres e escravizados, o modo mais generalizado de uso das terras fosse o compartilhamento com parentes e agregados. ${ }^{251}$

Mutirões para cumprir rapidamente tarefas que necessitavam agilidade, esforço e grande quantidade de mão de obra (tais como capinar os matos, abrir pastos, colheita, cavar poços, fazer cercas, construir casas, preparar a cobertura e o telhado das residências), adjuntórios e ferra do rebanho eram todas atividades comuns aos homens sertanejos que praticavam o trabalho coletivamente, reunindo vizinhos e parentes (possivelmente aos finais de semana quando quase todos estavam desobrigados das tarefas de roça e nas fazendas). Os serviços de colheita e preparo do solo e roçar também podiam ser negociados de modo que em cada dia da semana fosse executado coletivamente a tarefa em cada uma das roças das pessoas que participassem do mutirão. Possivelmente no final do dia, após a tarefa ter se completado e o trabalho encontrar-se plenamente realizado, faziam alguma refeição coletiva: matava-se um boi para assarem e bebiam aguardente. ${ }^{252}$

\footnotetext{
250. APEB. Antonio José Viera Araujo 08/3359/01 Juazeiro 1806.

251. Sobre as comunidades de fundo de pasto na Bahia, ver: Denilson Moreira de Alcantara e Guiomar Inez Germanias. Comunidades de Fundo de Pasto e Fecho de Pasto na Babia: luta na terra e suas espacializações. Disponível em: http://www.geografar.ufba.br/site/arquivos/biblioteca/publicacoes/ 1fc7a7b45a4d9d24bf645b8a9e99f120.pdf, acessado em 02/08/2012; Luiz Antonio Ferraro Júnior. Entre a invenção da tradição e a imaginação da sociedade sustentável: estudo de caso dos fundos de pasto na Babia. Brasília, 2008.

252. Sobre a prática coletiva do mutirão, ver: Clovis Caldeira. Mutirão: formas de ajuda mútua no meio rural. São Paulo, 1956; Hélio Galvão. O mutirão no nordeste. Rio de Janeiro, 1959; Antonio Candido. Os parceiros do Rio Bonito: Estudos sobre o caipira paulista e a transformação de seus meios de vida. Rio de Janeiro, 2010; Monica Dantas. Fronteiras Movediças. São Paulo, 2007.
} 
As festas religiosas também marcaram a sociabilidade das populações rurais da colônia. Todas as freguesias tinham ao menos uma igreja matriz em torno da qual orbitava a maior parte da vida social dos habitantes da região. O próprio povoamento de muitas vilas tinha por ponto central a Igreja, frequentada pelos moradores das fazendas pelo menos uma vez por semana. A exceção somente era feita no caso de unidades produtivas muito distantes, cujo deslocamento podia consumir dias de trabalho dos sertanejos, tornando a ida à Igreja menos frequente, visitada somente em datas mais emblemáticas do calendário litúrgico ou nos dias de casamento, batizado, velório.

A religiosidade também estava presente nas residências. Muitas fazendas possuíam a sua própria capela ou casa de oração compartilhada pelos donos, escravos e agregados. Mesmo nos inventários post-mortem mais humildes era comum aparecer entre os bens arrolados referências a imagens de santos e oratórios. No inventário de Custódia Maria Moreira foi possível notar a presença de "um oratório pintado de amarelo por fora e com suas flores dentro com uma imagem de Nosso Senhor crucificado" avaliado em $4 \$ 000.253$ Dentre as várias joias pertencentes à Anastacia Barbosa Leite, moradora no sertão de Jeremoabo, havia um rosário de 19 contas de ouro, uma imagem da Conceição de prata $2 \frac{1}{2}$ oitavas de ouro ( possivelmente aquelas pequenas imagens portáteis usadas como uma espécie de amuleto de proteção pessoal) ${ }^{254}$. Na casa de Antonio Pereira Pinto, no sertão de Carinhanha, também havia uma imagem de Nossa Senhora da Conceição. ${ }^{255}$ A viúva Mariana da Silva Santana, possuía uma imagem de Nossa Senhora da Conceição de ouro, certamente a santa mais adorada pelos fiéis. ${ }^{256} \mathrm{Na}$ fazenda de gado da Monissoba, no sertão do Rio São Francisco, Rita Maria da Conceição deixou ao seu viúvo um oratório de seis palmos, cinco imagens da família sagrada de palmo e meio, uma imagem da Conceição com coroa de ouro e uma imagem de Santo Cristo. ${ }^{257}$ No inventário do criador Lucas Fagundes dos Passos, além de um dos poucos instrumentos musicais avaliados (um órgão de mão), havia imagens de Santa Luzia, do Senhor Crucificado, da Gloriosa Santana e Santo Antonio. 258 A casa de oração do comerciante Antonio Alves de Lemos, próximo a feira de Capuame, contava com Imagem de Bom Jesus da Piedade com dois palmos e mais de altura, com seus aparelhos de prata, uma imagem de Nossa Senhora da Piedade aos pés da cruz e Santo Antonio. ${ }^{259}$

No episódio de encontro das filhas do vaqueiro Manoel Lopes, morador na Serra Limpa, com uma negra amocambada enquanto lavavam roupas na beira da lagoa, surgiu a pergunta sobre qual Igreja as crianças costumavam assistir missa. Elas responderam frequentar a Igreja Nossa Senhora da Piedade

\footnotetext{
253. APEB. Custodia Maria Moreira. 03/1141/1610/01 Mata de São João 1818.

254. APEB. Joaquim Maria da Fonseca 08/3415/14 Geremoabo 1790.

255. APEB. Antonio Pereira Pinto 02/728/1194/05 Carinhanha 1815.

256. APEB. José Antonio de Farias Lima 08/3415/01 Geremoabo 1792

257. APEB. Rita Maria da Conceição 08/3507/02 Jacobina 1791.

258. APEB. Lucas Fagundes dos Passos (04/1426/1895/04) Jeremoabo 1811.

259. APEB. Antonio Alves de Lemos 03/1141/1610/07 Mata de São João 1812.
} 
dos Campos. ${ }^{260}$ Dentre os membros do grupo itinerante que perambulava pela região da fazenda Serra Limpa, tirando o sossego das autoridades, havia muitos índios e negros, assim como um senhor já velho "em um carrinho e muitos santos de culto", denotando a religiosidade dos membros do acampamento, compartilhada por curandeiros, continuadores das tradições indígenas da jurema, assimilada a elementos das religiões de matriz africana, componentes do catolicismo popular tão difundido pelos sertões baianos no período setecentista e seguintes.

Interessante notar a quantidade de referências feitas à Nossa Senhora da Conceição, "senhora de todos", enquanto santa merecedora de ampla devoção nos sertões baianos. Segundo Luiz Mott, esta invocação específica de Maria, mãe de Deus, era alvo de muita devoção não só na América Portuguesa, mas também em todo o reino de Portugal, figurando como uma das santas com maior número de variedade das representações feitas em imagens de madeira e outros artigos. ${ }^{261}$

Procissões e novenas pedindo interferência divina nos assuntos terrenos eram comuns. Mesmo tendo fama de possuir beatos e religiosos fanáticos, não foi para os sertões baianos que encontramos o primeiro registro de uma procissão pedindo para que Deus intercedesse e trouxesse chuva. Em 31 de março de 1700, começo de estação seca, os devotos resolveram pedir autorização do Senado da Câmara de Salvador para organizarem uma procissão de preces em homenagem à venerada "Virgem Santíssima da Graça que por tradição dos antigos tinha obrado o milagre de chover". O objetivo era invocar a santidade como " advogada e intercessora para aplacar a divina ira”. A proposta era que o Senado arcasse com as despesas necessárias que a efetivação do milagre. ${ }^{262}$

Estudando o caso da negra alforriada, Bárbara Gomes de Abreu e Lima, o historiador Eduardo França Paiva cita a cidade da Bahia e Pernambuco como centros receptores de práticas culturais africanas que acabaram por se espraiar pelo interior até atingir a capitania de Minas Gerais. O caso excepcional da forra Bárbara Gomes de Abreu e Lima - que saiu de Sergipe ainda cativa e instalou-se na Vila de Sabará - estava na ampla rede social que tecera até o interior da capitania da Bahia, deixando espalhado sobre a guarda de pessoas distintas inúmeras pencas de balangandãs (geralmente apareciam pendurados na cintura das negras) contendo pequenas representações de ouro, figas, espelhos e imagens de Nossa Senhora da Conceição. Segundo Eduardo França Paiva, o balangandã da negra forra foi desmembrado para que ela conseguisse despistar melhor os oficiais da Inquisição, visto ser configurado

\footnotetext{
260. AHU. caixa 1 doc 8-9. Carta do Conde de Sabugosa, remettendo a D. João V os documentos seguintes. Bahia, 29 de maio de 1734.

261. Luiz Mott. "Cotidiano e vivência religiosa: entre a capela e o calundu". Fernando Antonio Novais (org.) História da Vida Privada no Brasil, vol. 1, São Paulo, 1997, p. 156.

262. AMS. Atas da Camara (1700-1718). “Termo de vereação de 31 de março de 1700”.vol. 7. , p. 15.
} 
como mandinga e feitiçaria o uso de talismãs e amuletos. ${ }^{263}$ Não nos esqueçamos dos vaqueiros estudados por Luiz Mott. Moradores na região do sertão de Jacobina, os negros mandingueiros foram denunciados ao Santo Ofício pelo costume de se protegerem dos perigos das estradas através do uso de escapulários e patuás contendo símbolos e orações que impediriam qualquer tipo de contratempo que por ventura ocorresse nos momentos de travessia das boiadas. ${ }^{264}$

Assaltos, ataques indígenas, acertos de contas eram sempre passíveis de ocorrer nos caminhos dos sertões baianos como em qualquer outro lugar. É comum a imagem reproduzida sobre um sertão apinhado de facinorosos, criminosos e contraventores. Considerado um território distante do poder do Estado, pontilhado por inúmeros quilombos, o sertão pode parecer a primeira vista "terra de ninguém". Todavia, analisando bem a sociedade forjada nos sertões baianos é possível compreender que a realidade se dava de modo um pouco distinto daquele esteriótipo reproduzido.

Devido as distâncias dos sertões em relação aos centro intermediário de decisão que era a cidade de Salvador (personificada pela figura do governador general) tudo o que se sabia sobre as partes interioranas era graças às informações vindas de mestres de campo, coronéis, capitães-mores, autoridades máximas no local, funcionários régios nomeados para tal finalidade. ${ }^{265}$ Todas as medidas tomadas pelo governador baseava-se única e exclusivamente no relato de terceiros que podiam manipular as informações conforme os seus interesses. A distância portanto, fazia com que os militares possuidores das mais altas patentes fossem a personificação do poder colonial nos sertões. ${ }^{266}$

Estes homens, faziam parte de famílias já estabelecidas nos sertões desde a virada do século XVII e XVIII e possuíam reconhecida fama pelos serviços prestados à Coroa. Enquanto combatentes das guerras dos bárbaros, desembaraçaram o interior da presença dos índios beligerantes, efetivando ao seu modo o domínio lusitano. Recebiam extensas sesmarias como pagamento pelos serviços prestados, tornando-se grandes fazendeiros e criadores de gado. Estendiam o seu poder através da hereditariedade, personificando sempre que possível o Estado em um processo de imbricação entre os poderes políticos e econômicos de uma região inteira. É comum observar nos documentos

\footnotetext{
263. Eduardo França Paiva: "Celebrando a alforria: amuletos e práticas culturais entre as mulheres negras e mestiças do Brasil.” Istvan Jancson e Íris Kantor (org.). Festa: cultura \& sociabilidade na América Portuguesa. Volume II. São Paulo, Hucitec, 2001, p. 506.

264. Luiz Mott. "Quatro mandigueiros do sertão da Jacobina nas garras da Inquisição". Inquisição e Sociedade. Salvador, 2010, p. 121-169.

265. As correspondências dos governadores-gerais guardadas nos maços do Arquivo Público do Estado da Bahia e as fontes transcritas e integrantes da coleção Documentos Históricos da Biblioteca Nacional do Rio de Janeiro, utilizados largamente nesta pesquisa são exemplos flagrantes da produção de registros por parte dos militares que tinham por obrigação cumprir ordens e manter informado o governador estabelecido na cidade de Salvador.

266. Ana Carolina Gonçalves Leite, op. cit.; Carlos Toledo de Almeida, op. cit.; Renata Santos Rente. op. cit.
} 
compulsados que os fazendeiros mais abastados eram ao mesmo tempo representantes da justiça, ocupantes de cargos estratégicos nos sertões baianos e possuíam patentes militares.

Para justificar suas medidas, o recebimento de extensas terras em forma de sesmarias, os privilégios e os desmandos cometidos era evidente que precisavam desenhar um sertão de difícil controle, exagerando muitas vezes nos contornos da imagem a ser projetada diante das autoridades centrais. É razoável de fato pensar que os sertões se configuravam também pelos espaços de sombra. As terras dominadas por indígenas e os mocambos (localizados nas regiões de mais difícil acesso, provocando pânico aos forasteiros) de fato existiam e escapavam sempre que possível ao controle régio. Todavia, estas regiões de sombra não podem ser confundidas com a ausência de Estado. Se todos os sertões eram divididos por distritos vigiados e patrulhados por inúmeros homens de patente (como nos fazem crer as cartas entregues aos montes para os regimentos dos sertões); se o interior da capitania da Bahia era praticamente dividida entre as zonas de influência dos coronéis Garcia D'Avila e Pedro Barbosa Leal (grandes fazendeiros, funcionários régios e rivais, digase de passagem), como é possível falar de supremacia do poder exclusivamente privado se eles eram funcionários régios que respondiam há tempos por suas ações ao governo central e ao Conselho Ultramarino?

A unilateralidade da posição do Estado diante dos conflitos pode ser acompanhada também nas poucas devassas e querelas que restam para os sertões baianos do século XVIII. Ali conseguimos observar que muitos dos embates que ganharam uma certa dimensão jurídica tinham como réus pessoas que cometeram algum crime contra a propriedade (roubos) ou se envolveram em conflitos armados (com uso de pistolas e armas proibidas pelas Leis do Reino) resultando em morte de algum membro inserido no corpo social da colônia. ${ }^{267}$ O próprio Juiz Ordinário atuante temporariamente no sertão do Rio de Contas falava sobre a falta de averiguação dos crimes cometidos naquelas paragens "as barbas da Justiça". ${ }^{268}$ A todo momento, o argumento da autoridade era o temor pela perda de controle, uma espécie de medo pela quebra de monopólio do Estado enquanto único agente legítimo para mediar os conflitos e portanto passível do uso exclusivo da violência. ${ }^{269}$ Tudo se passava como se os desmandos e crimes ocorridos, caso não fossem penalizados exemplarmente, pusessem gradativamente em cheque a soberania régia na localidade. Fora os eventos mais escandalosos, vinculados ao roubo ou morte de grandes mercadores, oficiais de justiça ou militares, poucos foram os casos que mereceram o desgaste de papel e tinta. Segundo as autoridades estabelecidas na capitania da Bahia, entre os anos de 1710 a 1721 ocorreram

267. Esta é somente um hipótese que precisa ser verificada na totalidade dos documentos que permanecem guardados no Arquivo Publico do Estado da Bahia e fazem parte do conjunto de papéis produzidos pelo Tribunal da Relação. Para um estudo sobre os processos abertos pelo Tribunal da Relação, ver: Roque Felipe de Oliveira Filho. Crimes e Perdões no ordem jurídica colonial. Babia (1750-1808). Salvador, 2009

268. APEB. Maço 201-1. Juiz Ordinário da Vila de N. S. do Livramento das Minas do Rio de Contas (25/06/1765) doc. 07

269. Renata Rente, op. cit. 
532 mortes por arma de fogo na região de Jacobina. Nenhum deles foi apurado. ${ }^{270}$ Mas eles só deviam ser apurados e mereciam ter os envolvidos punidos na medida em que não estavam vinculados a um crime que foi cometido em nome do Estado, com o objetivo de garantir a sua soberania ou eliminar seus oponentes diretos.

Dos documentos existentes no Arquivo Público do Estado da Bahia, chama a atenção a tentativa das autoridades em problematizar o uso indiscriminado de armas pelos viandantes que perambulavam pelos sertões. Os casos relatados certamente tinham por objetivo mostrar que se não houvesse um rigor maior quanto à proibição do uso de armas, permitida única e exclusivamente para as atividades executadas pelos funcionários régios, a situação sairia do controle do poder colonial. Caso concreto foi o relato da fuga de Antonio Joseph Ferraz. Através do pedido enviado pelo tabelião da Vila de Rio de Contas, os oficias de justiça Manoel Vieira Pessoa e Manoel Luis Lopes foram até o arraial do Mato Grosso penhorar [sic] Antonio Joseph Ferraz. No caminho de volta para a vila, no dia 4 de junho de 1765 , as nove horas da noite chegou a cavalo Bernardo da Rocha Ribeiro acompanhado por mais quatro homens "seus com bacamartes, pistolas e outras armas violentamente". Feriram um dos oficiais e "fizeram voltar para trás com o preso". 271

O processo movido pelo Juiz Ordinário da Vila de Santo Antonio do Urubu, Antonio da Silva Caldas Cavalcante Albuquerque, tendo por réu o sargento-mor José de Pinnaque para apurar as denúncias de cárcere privado, pronunciamento de palavras injuriosas e tentativa de agressão contra Luciano Lopes de Brito, homem de nação vermelha, certamente só ocorreu porque o moço ofendido pelo termo pejorativo de "tapuinha" era um "oficial da Justiça". Cumprindo o seu ofício de caminheiro, foi entregar uma carta de cobrança no dia 9 de julho de 1763 ao sargento-mor acusado. A fazenda ficava distante do centro da vila. Chegando já pela noite, encontrou o réu "arranchado" no engenho da fazenda. O Sargento-mor José de Pinnaque ficou nervoso com a ousadia do "caminheiro da Justiça" em ir até a sua casa para cobrar dívidas através de "duas cartas de reconhecimento dos créditos". As cartas foram emitidas pelo Dr. Ignacio de Araujo Lasso de Mello (possivelmente um advogado estabelecido na Vila de Urubu) a pedido de capitão Manoel Luis de Souza que foi até o centro da comarca para resolver várias pendências de seu cunhado, José Vanique, e aproveitou para executar a dívida. Quando o "oficial da Justiça", Luciano, solteiro, morador da vila de Urubu, 25 anos, começou a ler o conteúdo da carta, o sargento-mor chamou dois escravos para amarrarem o homem de nação vermelha com uma corda e quando iam começar à açoitá-lo, chegou um cunhado do sargento-mor e interviu imediatamente, soltando Luciano que voltou o mais rápido possível

270. Decerto o documento foi produzido para demonstrar o salto qualitativo da região após o estabelecimento da Vila., ocorrendo somente dois assassinatos no ano de 1724. AHU. Bahia. c. 20 doc. 1834. "Carta do vice-rei ao rei informando sobre a devassa que instalou na vila de Jacobina."

271. APEB. Maço 201-1. Juiz Ordinário de N. S. do Livramento das Minas do Rio de Contas (02/09/1765) doc. 09 
para casa onde morava com Antonio de Souza do Sacramento, criolo, oficial de alfaiate, solteiro, morador na vila de Urubu, 30 anos, arrolado como uma das testemunhas do auto de devassa. ${ }^{272}$

As mortes aparentemente arbitrárias cometidas por um bando no sertão de Tuiuiu chamou a atenção do Juiz Ordinário da Vila de Itapicuru em 03 de julho de 1767. O capitão-mor, Bernardo Carvalho da Cunha, dava notícias que no sertão de Tuiuiu, cinquenta léguas da vila, havia uma cavalaria que tinha saído com José Gomes da Silva em direção ao rio Jaguaribe. Talvez a vítima fosse um comerciante ou passador de gado retornando ao Piauí. No caminho se agregaram mais pessoas que, próximo a travessia do Riacho da Brígida, mataram José Gomes de Silva e enterraram-no próximo ao rio. Os membros da cavalaria simplesmente, depois de terem cometido o crime, seguiram pelo rio São Francisco e voltaram para a vila de Itapicuru com os bens do morto. Pelo escândalo causado e a ousadia dos matadores, todos os envolvidos foram remetidos presos a cadeia da cidade da Bahia. ${ }^{273}$

Para garantir que os acusados de infringir as leis do Reino e os causadores de desordens fossem punidos, valia mobilizar todo o aparato militar disponível, de acordo com os interesses das autoridades. Este foi o caso da tentativa espetacular de prisão do "revoltoso" Leandro. Não sabemos qual foi exatamente o crime que cometera, a única informação que temos era a sua cor: mulato. Em 28 de dezembro de 1723 o governador-geral enviou "ordem passada ao requerimento do Coronel Garcia D'Avila" para mandar:

“[...] todos os oficiais de milícias, entradas ou Henrique Dias a quem esta se apresentar prendão logo a um mulato por nome Leandro, em qualquer poder [sic] ou parte donde se achar, principalmente no sítio do Rio Real donde é filho, e de presente se acha, e quando haja alguma pessoa ou pessoas que o defendam as tragam presas à cadeia desta cidade e o mesmo se ofereçam com em esta diligência[... ."274

Um dos poucos movimentos coletivos e possivelmente propagadores de experiências divergentes daquelas desejadas pelo poder colonial de que temos notícias para o século XVIII, foi o caso de um moço que perambulava pelo interior da capitania da Bahia se auto intitulando "Príncipe do Brazil". Este sujeito e seus "seguidores" são dignos de estudo mais profundo se houver ainda algum registro de entrada na cadeia da cidade, processo, devassa ou algo semelhante. Por onde passava, era seguido por uma quantidade significativa de indígenas, negros fugidos e pobres, resultando no desespero das autoridades coloniais. Após o recebimento desta informação, o governador-geral enviou diversas cartas a capitães-mores e coronéis para providenciarem de imediato a captura do ... infrator? A autoridade máxima da América Portuguesa tinha recebido a notícia em 01 de outubro de 1733 de que o dito moço estava vagando pelos sertões indo em direção à capitania do Pernambuco. Enviou imediatamente ordens para que todos os coronéis e capitães mores dos regimentos daquelas bandas dos sertões mobilizassem seus homens na captura

272. APEB. Maço 201-1. Juiz Ordinário de Vila de Santo Antonio do Urubu (05/11/1762) Doc. 03

273. APEB. Maço 201-1. Juiz Ordinário da Vila de Itapicuru (03/07/1767) doc. 4

274. APEB. Secção Colonial. Portarias (1722-1724) n. 686, fl. 214. 
do insurgente. $\mathrm{O}$ mais surpreendente é que no dia 07 de outubro de 1733, ou seja, uma semana depois da ordem de prisão do tal moço que supostamente se intitulava príncipe do Brasil, o governador já comemorava a prisão bem sucedida. ${ }^{275}$ Será que de fato o acusado se intitulava "príncipe do Brasil"? Será que esta não era uma maneira das autoridades régias entenderem e colocarem dentro de suas possibilidades mentais a existência de uma espécie de liderança política diferente daquilo que estavam acostumados? Qual a possibilidade deste argumento ter sido colocado para aumentar a gravidade do caso e imputar ao possível infrator o crime de desrespeito à soberania Real, tal como o crime de lesa-magestade? Estavam diante de um movimento messiânico semelhante ao sebastianismo? Independente do caráter do movimento em si, sem dúvida uma quantidade de não-brancos perambulando pelos sertões, sem eira nem beira, sem fixar-se a uma terra, sem exercerem seu papel enquanto trabalhadores compulsórios em potencial, não era exatamente a imagem ideal de súditos dóceis tão almejados pelas autoridades. A eficiência do aparato do Estado na prisão do acusado serve para repensarmos de modo sincero a pretensa ausência de Estado nos sertões baianos, a morosidade com que as informações chegavam ou as supostas distâncias intransponíveis que impediam o progresso técnico da região confundido a todo momento, por questões ideológicas, com atrofia econômica. Aqui novamente, só temos a informação sobre o ocorrido porque houve o despacho de diversas ordens de prisão do contraventor de quem não sabemos nem ao menos o nome.

A violência existia nos sertões baianos como também era frequente em qualquer outra parte da colônia, principalmente no interior das fazendas e unidades produtivas. ${ }^{276}$ Crimes ocorriam: fato. Assim como ocorriam na movimentada Salvador ou na civilizada metrópole. Roubos eram passíveis de acontecer mesmo tendo por objeto os aparentemente seguros cofres públicos que somente homens muito bem educados e honrados tinham acesso, como foi o caso das acusações feitas pelo desembargador João Eliseu de Souza sobre os desfalques na cobrança dos donativos reais. $\mathrm{Na}$ ocasião, a suspeita recaiu sobre o tesoureiro Pedro Moniz, em 1753.277 Ou ainda no episódio em que houve o roubo dos cofres da fazenda, em 1724. ${ }^{278}$ Tão pouco podemos nos assustar com a quantidade de armas que circulavam pelas bandas sertanejas sempre pintadas como terra de ninguém. Raciocinemos: as boiadas possuíam em média de duzentas a trezentas reses. Calculando cada cabeça de gado como possuindo o valor equivalente a $4 \$ 000$ réis, estamos falando de um montante de $800 \$ 000$ a 1:200\$000 réis ambulantes. Ou seja, evidentemente os

275. APEB. Secção Colonial. Cartas ao governo (1729-1733) n. 150, fl. 297 v.

276. A título de curiosidade, o único aparelho de tortura de escravos encontrado entre os documentos compulsados foi um tronco avaliado em $1 \$ 000$ logo antes de arrolar os 11 escravos pertencentes a Fazenda do Sítio do Morro na freguesia de São José de Itapororocas. APEB. Francisco Xavier da Motta e Sá (03/931/1400/11) Cachoeira, 1818.

277. AHU [Bahia]. CU_003. c. 6 doc. 768-769. Carta de desembargador João Eliseu de Souza, informando o Rei dos desfalques que havia na cobrança do donativo real e accusando o Thezoureiro Pedro Moniz de faltas graves. Bahia, 14 de novembro de 1753.

278. AHU. [Bahia] CU_005. cx. 19. doc. 1660. Carta do vice-rei e governador-general do Brasil, conde de Sabugosa, ao

rei comunicando o provável furto contra os cofres da Fazenda. Bahia, 27 de março de 1724. 
condutores andavam sim fortemente armados. Ninguém correria o risco de voltar com as mãos abanando para dar explicações lamuriosas ao dono do gado sobre seu lastimável prejuízo.

Dentre as armas mais citadas nos inventários post-mortem dos sertanejos, é possível elencar aparelhos de facas Parnaíba avaliados em média por $16 \$ 450$, facas aparelhadas de prata $12 \$ 000$, espingardas taboca $4 \$ 000$, espingardas Lazarina $4 \$ 000$, Bacamarte $2 \$ 500$ e pistolas. ${ }^{279}$

Por muito tempo as armas de fogo foram proibidas "pela lei do Reino", mas certamente a ordem não foi obedecida, pelo o que é possível notar nos inventários. Talvez a exceção fosse o uso destes dispositivos pelos homens de patente, mas nem todos os inventariados cujas armas de fogo foram arroladas eram militares. Vez por outra os sertões passavam por algumas cenas trágicas causadoras de comoção por parte da população em geral. Despertavam o pânico das autoridades que temiam perder o controle da situação.

$\mathrm{Na}$ região do sertão de Rio de Contas, nos arrebaldes da estrada geral que seguia para Minas Gerais, ficava a movimentada taverna de bebidas e molhados pertencente a João Gomes da Silva. Em 1765, seguia viagem o "homem viandante" morador de Minas Gerais, Antonio Ferreira Braga, "com seu comboio de moleques novos". Parando o comboieiro por um tempo na taverna, teve uma discussão com o dono da venda que dizia respeito ao “tráfego de negócios destas e aquelas Minas". A rixa já antiga entre os dois homens transformou-se em uma confusão, resultando no disparo de dois tiros saídos das duas pistolas que o comboieiro Antonio Ferreira Braga tinha em mãos. ${ }^{280}$

No sertão do Rio Real a reclamação do capitão-mor Manoel Francisco da Cruz Lima denunciou o uso de pistolas por Antonio José dos Santos. Depois de uma briga e troca de injúrias, Antônio acusou publicamente o capitão-mor de ser "latrocinioso" e acostumado a fazer e desfazer justiça por dinheiro. O capitão-mor, redator da correspondência dirigida ao governador da Bahia, evidentemente desmentiu a calúnia, afirmando ser um homem abastado não precisando se servir de seu poder para conseguir dinheiro, acusando a outra parte de ser "acostumado a revoluções e inquietações por cujo motivo tem sido punido várias vezes pela justiça". No momento da confusão, Antonio José dos Santos, "armando-se de uma cattana e um jogo de pistolas. Colocou-as na mesa de sua casa e disse" em tom desafiador "que cumprissem qualquer ordem severada contra ele, após ser ameaçado de prisão." 281

Aqui novamente faz-se necessário repetir. A violência estava longe de ser uma peculiaridade dos sertões, como querem alguns autores mais

279. APEB. Raimunda Maria 07/2869/03; APEB. Lucas Fagundes dos Passos (04/1426/1895/04) Jeremoabo; APEB. Paulino Pereira e Rosa Barbosa 08/3406/08.

280. APEB. Juiz Ordinário da Vila de N. S. do Livramento das Minas do Rio de Contas (25/06/1765) doc. 07

281. APEB. Maço 192. Correspondência recebida pelo governo da Bahia Capitão mor das Ordenanças da Vila de Santa Liza do Rio Real 1781-1789 ( ver onde ficava esta vila) 
emocionados com a quantidade de reclamações sobre a falta de lei e autoridade régia nas paragens interioranas. ${ }^{282}$ Ora, basta deixarmos de lado o par dicotômico ordem/caos para lembrar-mos que primeiramente a ausência da lei do Estado não significa ausência de lei. A falta de um funcionário público sempre a regular, normatizar e docilizar mentes e corpos coloniais não significava a automática inexistência de códigos sociais e compartilhamento de comportamentos aceitos e respeitados por seus habitantes em um determinado espaço. Dito de outro modo: os sertões baianos estavam longe de ser "terra de ninguém". Mesmo que seus "espaços de sombra" permitissem a reprodução momentânea de modos de vida divergentes daqueles desejados pela Coroa, eles só se reproduziam nos lugares em que as autoridade régias - personificada em seus fazendeiros, sesmeiros, capitães e "práticos dos sertões" - permitiam ou nos espaços que ainda não haviam sido devidamente esquadrinhados.

Sendo assim, os sertões baianos do século XVIII não eram essa pretensa "terra sem lei" e muito menos um espaço dominado irrestritamente por grupos indígenas, quilombolas, nômades sem eira nem beira. Quem dera o fossem. Não prevalecia também única e exclusivamente o poder dos grandes fazendeiros e homens de patentes, por mais que esta fosse uma tendência geral sobretudo para o final do século XIX, como bem demonstra a historiadora Monica Duarte Dantas. Enquanto os sertões baianos ainda eram configurados como zonas de fronteiras abertas, com grande oferta de terras e uma população relativamente autônoma - possuidora de condições mínimas para reproduzir seus meios de vida com margem de manobra em relação aos grandes fazendeiros e sesmeiros - não prevalecia os desmandos das autoridades régias e dos proprietários das maiores unidades produtivas. Evidente que as elites sempre tentaram controlar a população que se encontrava sobre a sua jurisdição, permitindo somente a reprodução de modos de vida que não fossem considerados uma ameaça direta aos seus interesses. Redundante dizer que a sociedade sertaneja foi forjada no processo violento de expropriação das terras indígenas e na introjeção de populações africanas escravizadas ou não. Todavia, contraditoriamente, o controle emanado das autoridades régias não atingiam todas as esferas da sociabilidade sertaneja na medida em que os próprios donos das terras não davam conta de ocupar pessoalmente toda a área adquirida, sendo obrigados a delegar a terceiros a tarefa de garantir a sua propriedade através da ocupação e produção (voltada para o mercado ou não).

Este quadro, ou melhor, estes mecanismos de controle sobre os sertanejos irão mudar qualitativamente e substancialmente quando o acesso a terra e o controle sobre a mão-de-obra tornar-se um problema para as elites. A aumento gradativo da pauperização da população sertaneja, o crescente desgaste do solo depois de séculos de pisoteio e poucos cuidados em relação a produção pecuarista, a diminuição das propriedades médias e a concentração

282. Para um estudo pioneiro e direcionador de várias abordagens sobre os sertões mineiros setecentistas, tendo por principal influência teórico o trabalho de Eric Hobsbawn, Bandidos, ver: Carla Maria Junho Anastasia. A Geografia do Crime: violência nas Minas Setecentistas. Belo Horizonte, Ed. UFMG, 2005. 
dos grandes latifúndios, o fim do tráfico de escravos e a pressão mercantil sobre a terra serão fatores que marcarão substancialmente a mudança estrutural a qual os sertões baianos estarão submetidos na passagem do século XIX para o século XX. Mas esta já é uma outra história. ${ }^{283}$

283. Para uma análise crítica das mudanças as quais os sertões baianos, sobretudo a comarca de Itapicuru, estavam submetidos no final do século XIX, momento de formação do Arraial de Canudos, ver: Monica Duarte Dantas. Fronteiras Movediças. São Paulo, 2007. 


\title{
CAPÍTULO 3: A CIDADE DE SALVADOR
}

\begin{abstract}
"É possível que sendo este país um daqueles que entre outros, tendo uma quase contínua primavera e que e os seus campos estando sempre cobertos de verdura e quee contendo as mais vastas e dilatadas campinas e ainda muito poucas povoações, qualidades todas estas próprias para a criação e multiplicação de gados, seja o que quase continuamente sofra faltas deste gênero para a subsistência dos seus pouco numerosos habitantes?"
\end{abstract}

Moradores da Cidade da Bahia de Todos os Santos em representação ao Senado da Câmara, 1797.

Cidade da Bahia de Todos os Santos, 8 de fevereiro de 1797. Uma representação assinada por centena de moradores da primeira capital e de uma das mais importantes praças comerciais da América Portuguesa foi endereçada aos senadores contendo uma série de propostas no sentido de indicar quais eram as melhores medidas factíveis para sanar os problemas de contínua falta de carne que afligia a cidade naquele ano. ${ }^{1}$ Considerada pelos moradores como o principal alimento e gênero de primeira necessidade, os problemas no abastecimento da carne verde causavam um aumento não só do preço daquele gênero em específico, mas de todos os outros consumidos pela população. $\mathrm{O}$ redator da carta, homem certamente ilustrado, afirmou categoricamente não ser possível interromper o ciclo vicioso da carestia caso não adotassem um "sistema fundado na razão, justiça e nos interesses recíprocos da sociedade," embasado nos "séculos mais iluminados e de todos os países onde se conhecem os verdadeiros princípios da economia estabelecido por escritores de todas as nações que sobre matérias econômicas tem escrito." O sistema proposto resumia-se na liberalização do comércio de carne, retirando todos os obstáculos, proibições, taxas que pudessem diminuir a circulação do gênero.

Segundo a representação escrita pelos moradores, a simples abolição do imposto sobre a carne já seria um grande passo no sentido de sanar os problemas referentes ao abastecimento, não só pela violência a que submete o povo (obrigado a pagar altos tributos) e pelo vício da cobrança feita há tempos imemoráveis, mas principalmente pela própria irracionalidade e ineficiência na qual a lógica de tributação estava inserida, necessitando o pagamento de inúmeros agentes, empregados na constante vigilância de estradas, caminhos e registros. Mesmo assim, o aparato coercitivo continuava possibilitando as brechas abertas pelo contrabando.

1. APEB. Maço 201-14. Correspondência recebida pelo governo. Senado da Camara da Bahia (17831799). Carta de 08 de fevereiro de 1797, fl. 138. 
Em um sistema baseado nas barreiras econômicas e na cobrança de impostos, não era possível haver em nenhum momento uma abundância segura, nem mesmo em períodos cujos limites climáticos não estavam colocados enquanto obstáculos. Ou seja, se não houvesse uma liberalização da economia, pouco importava se os períodos de seca se extinguissem ou as grandes inundações limitadoras da produção e fluxo das boiadas: a carne continuaria sendo um alimento escasso na cidade da Bahia de Todos os Santos.

Sempre havia uma desculpa por parte dos envolvidos nos comércio do gado para justificar a carestia. Não foram poucas as denúncias contra o administrador Capitão Manuel Henriques que atuava na feira de Capuame, citado no primeiro capítulo. Acusado de extorsões e violências, a situação do abastecimento piorava nos momentos de impedimentos físicos e limites naturais que incidiam sobre a condução das boiadas, visto desanimar ainda mais os produtores a encaminhar gado para a feira, não bastando nenhum tipo de plano ou nova administração para melhorar a qualidade do fornecimento do gênero ao centro urbano.

Propondo que todo o sistema fosse pautado na justiça e na razão, tendo como exemplo as nações que adotaram como princípio a liberdade econômica, os redatores da representação referiam-se às leis positivas do pensamento liberal. Citaram o exemplo da Toscana que, assim como "o resto da Itália", no ano de 1764 passou por um terrível período de fome. Depois da certeira decisão de retirar as barreiras econômicas, a península nunca mais voltou a passar por aquelas crises. Até mesmo com a decisão de abolir as taxas referentes ao comércio de farinha de mandioca, D. Fernando José de Portugal conseguiu garantir que não houvesse mais grandes faltas do gênero na praça comercial da cidade da Bahia. ${ }^{2}$

Teoricamente a carne seria ainda mais fácil de ser livre das taxações abusivas, quando comparada com a farinha de mandioca, além de possuir condições naturais que impediam o armazenamento do produto. Primeiramente porque o carne não podia ser estocada em armazéns, tendo de ser prontamente cortada (quando chegava na cidade) visto ser custoso a sua manutenção em currais e poder incorrer em prejuízos caso houvesse mortandade entre o rebanho. Impedindo o intermédio dos marchantes, ficaria garantido que nenhum esquema de diminuição artificial de oferta para forçar uma elevação nos preços seria praticada.

O alto preço da carne resultava, segundo a carta, no baixo consumo do alimento pela população mais pobre. Quando esta enorme parcela da população consumia a carne bovina não compravam nos açougues mas sim através dos forminas (contrabandistas) na região da praia ou nos arrebaldes da cidade pelo preço de seis patacas. Devido os riscos corridos pelos contraventores, fazia-se necessário que vendessem a carne por um preço bem menor garantindo que conseguissem rapidamente se livrar da prova do crime,

2. Aqui há evidente exagero dos autores da representação no sentido de exemplificar a operabilidade da ideia que possuíam, colocando os exemplos como prova de convencimento para às autoridades. 
além de corromperem meirinhos e "belleguis". Deste modo as rendas do Conselho ficavam triplamente prejudicada: seja pelo não pagamento do direito de entrada na feira de Capuame, pelo não pagamento do direito de corte no matadouro e pelo menor faturamento dos arrematantes dos talhos, visto a carne não ser exclusivamente comprada nos açougues. De acordo com o pensamento dos autores da representação, qualquer pessoa sensata poderia verificar que os grandes males no fornecimento de carne à cidade era sem dúvida as exorbitantes taxas e as proibições impostas ao comércio, desprezando o bem público e beneficiando uma "classe" da população em detrimento da outra. Estimavam que se o novo sistema de livre mercado fosse adotado, a carne poderia ser comercializada pelo preço de dois cruzados.

A todo o momento, os redatores da representação questionavam como um local com condições naturais tão favoráveis, com pastos e um clima sempre próximo à primavera podia ser o mais afetado com a falta de alimentos. Comparando com a Inglaterra e Irlanda, "menos férteis, menos extensos e mais povoados e que no espaço de seis meses não produzindo a terra quase coisa alguma", pairava a pergunta: como um ilha era capaz de sustentar toda sua população, manter abastecida a extensa frota da marinha mercante e de guerra, vendendo ainda carne para as naus de outros lugares da Europa?

Descartavam categoricamente a ideia (propagada largamente naquele tempo) sobre o papel das constantes e severas secas enquanto principal agente causador das carestias. Caso assim o fosse, os engenhos e as vilas do Recôncavo também estariam desabastecidos e cessariam de chegar as constantes boiadas destinadas àquelas unidades produtivas. Isso não condizia com as observações dos moradores que podiam certificar o contínuo abastecimento da região vizinha.

A atribuição das catástrofes e faltas de gêneros às constantes enchentes nos rios que cortavam as estadas das boiadas também foi facilmente descartada pelo seu caráter momentâneo, visto o nível dos rios baixar com relativa rapidez depois dos momentos de cheia. Todavia, o problema seria facilmente solucionado caso houvesse boa vontade política para impulsionar uma generalizada construção de pontes para a travessia dos rebanhos sertanejos.

As manobras executadas por "monopolistas e atravessadores" não poderiam existir caso não houvesse mais a cobrança de taxas. Ou seja, o contrabando e o desvio eram cada vez mais fortalecidos em um espaço econômico controlado visto a lucratividade crescer somente em um ambiente que propiciava a ação de sonegar o imposto e incentivava indiretamente a venda da carne em pontos não regulamentados pelo governo, fazendo com a que o produto chegasse ao consumidor final por um preço bem maior.

Evidentemente, como leitores de Adam $S_{m i t h}^{3}$, os redatores da representação acreditavam que a retirada de qualquer intervenção ou taxação

3. A referência ao autor Adam Smith é feito a partir da versão em Inglês. 
do governo sobre o comércio resultaria em uma abundância gerada pela livre concorrência e a natural e automática queda dos preços. Lamentavam que este princípio, "estabelecido pela razão", era pouco conhecido fora das partes civilizadas da Europa (leia-se Inglaterra e França) violando "abertamente o direito o mais sagrado da propriedade que as mesmas leis de Sua Majestade mandam respeitar", visto os "indivíduos" não conseguirem ter acesso aquilo que conseguissem adquirir graças a sua "própria indústria”.

Em última instância, todos os problemas estavam ligados ao impedimento que tinham de discutir abertamente e livremente as "verdades" sobre os princípios da economia, prevalecendo ideias ultrapassadas sem fundamento na razão. Segundo os autores, era muito propagada a ideia de que se não houvesse uma interferência do governo por intermédio das taxações, a população estaria exposta a alta dos preços que poderiam chegar a valores excessivos, não levando em consideração que eram justamente as taxas, em períodos de carestia, as grandes causas dos aumentos dos preços.

Caso o comércio fosse livre, (entendido como a troca mútua de mercadoria, tendo por base o interesse de dois indivíduos) a única lei que prevaleceria sobre o abastecimento dos gêneros alimentícios seria a lei "dos interesses particulares", visto ser comum a todo o comerciante o simples cálculo de comprar as mercadorias em região de abundância e vendê-las nas partes em que faltavam e faziam-se necessárias, gerando a concorrência que empurraria automaticamente os preços para baixo, chegando ao seu "estado natural", resultando finalmente na abundância.

Voltando ao caso específico do abastecimento da carne verde, os escritores da representação endereçada ao Senado propõem um princípio típico do pensamento iluminista: um mapeamento detalhado de todas as etapas de produção e condução das boiadas. Um melhor conhecimento de todo o processo resultaria em uma exploração mais eficiente. Primeiramente, era preciso saber quanto custava um boi nas "próprias porteiras das fazendas". Fazia-se necessário calcular ainda a concorrência, além das secas que costumavam assolar os currais. Depois, teria de ser feito um cálculo referente às frequentes perdas de bovinos nos caminhos e todas as despesas dos passadores até chegarem a cortar por conta própria a carne nos açougues ou até venderem aos marchantes.

Perguntam ainda como podiam os marchantes e criadores serem obrigados a vender o gado na cidade de Salvador de modo desinteressado se em outros lugares conseguiriam melhor saída e retorno financeiro para seus negócios se não fosse com base na violência? "Se ele não tira um benefício suficiente que o anime a continuar esta especulação, como é possível que ele a possa continuar?" É aceitável que em meio à falta de carne e a consequente baixa arrecadação do imposto em 1783, o administrador da renda dos talhos, Manoel Rodrigues de Magalhães, tivesse a coragem de propor o aumento do preço da carne vendida nos açougues?

Era necessário, por fim, que os criadores e marchantes se guiassem pelo lucro, fazendo com que se sentissem estimulados a participar do jogo da 
concorrência, aumentando a produtividade e comércio. "Poder-se-iam negar ainda esta verdade tão sentida, tão conhecida, tão experimentada pelos que traficam?" O aumento da venda do açúcar e de outros gêneros agrícolas só ocorreu depois da queda das taxas. Nenhum outro gênero possuía tanta cobrança de impostos quanto o gado e a carne verde. Até mesmo a charque do sul, a carne seca ou carne do sertão vindas do Ceará eram livres de impostos.

O documento não chegou em nenhum momento a denotar uma crítica que extrapolasse o âmbito do abastecimento interno. A utopia liberalt aparecia como um modo de trazer à luz do funcionalismo público aquilo que a razão havia revelado em outras nações europeias. Todavia, talvez fosse uma questão de tempo o desdobramento do novo pensamento já propagado pelos meios revolucionários americanos e europeus, aprofundando a crise e antecipando o estabelecimento de uma ordem liberal política e econômica. ${ }^{5}$ Não é de se espantar que muitos dos descontentes com as taxações e favoráveis à adoção do livre comércio participassem um ano depois da Conjuração Baiana. ${ }^{6}$

\subsection{A carne e a espacialidade de Salvador}

Com uma população de aproximadamente 40 mil moradores na última década do século XVIII ${ }^{7}$ não é difícil imaginar que uma grande quantidade de alimentos fosse destinada ao consumo dos habitantes. Fora a população fixa, assim como em qualquer cidade portuária, Salvador contava com a constante movimentação de viajantes, itinerantes e passageiros das numerosas embarcações que aportavam em uma das principais praças comerciais e porto do Hemisfério Sul. As Naus das Índias eram abastecidas naquele local e só seguiam viagem quando conseguissem munir sua tripulação de víveres. ${ }^{8}$

Saindo semanalmente da feira de Capuame em direção à cidade da Bahia de Todos os Santos, iam marchantes, escravos e soldados conduzindo os rebanhos necessários para alimentar os moradores da primeira capital da

4. Para uma crítica ao pensamento liberal devido a relação direta entre livre comércio de grãos e a proliferação da fome na periferia a partir do século XIX, ver: Karl Polanyi. A Grande Transformação. Rio de Janeiro, 1980; Mike Davis. Holocautos Coloniais. Rio de Janeiro/ São Paulo, 2002.

5. Reinhart Koselleck. Crítica e crise: uma contribuição à patogênese do mundo burguês. Rio de Janeiro, 2009.

6. Sobre a Conjuração Baiana, ver sobretudo os trabalhos de Istvan Jancsó. Na Babia contra o Império: história do ensaio de sedição de 1798. São Paulo, 1996; Patricia Valim. Corporação dos enteados: tensão, contestação e negociação política na Conjuração Baiana de 1798. USP, São Paulo, 2012.

7. Sobre as várias informações divergentes quanto ao número da população residente na cidade da Bahia, ver: Maria Aparecida Silva de Sousa. Babia: de capitania a provincia,1808-1823. USP, São Paulo, 2008. p. 46; Richard Graham. Alimentar a cidade. Das vendedoras de rua à reforma liberal (Salvador, 17801860). São Paulo, 2013, p. 38.

8. Há vários registros de atraso das Naus devido aos problemas de abastecimento. DH. "Carta que se escreveu ao Desembargador José de Sá, Antônio da Silva Pimentel, Garcia de Ávila, Domingos Afonso Sertão, e ao Doutor André Leilão de Melo, sobre mandarem vir gados das suas fazendas, que se lhes segura o preço de cruzado enquanto estiver aqui a frota. " 12 de setembro de 1705 , vol. 41, p. 128; DH. "Carta que se escreveu ao Capilão-mor Baltasar Vanhique, e ao Capitão João de Seixas Ferraz para fazerem vir todas as boiadas, que àquele distrito da Água Fria chegarem, para esta cidade. " 18 de setembro de 1705.vol. 41, p. 131; DH. "Portaria para o Capitão-mor Domingos Alves fazer vir para esta cidade todo o gado que chegar ao distrito de Capuame " 23 de abril de 1712 , vol. 53, p. 160, dentre outros. 
América Portuguesa. Caminhavam por um traçado bem definido até chegar ao matadouro público. Deixando Capuame na quarta feira ou na quinta feira pela manhã, atravessavam o rio Joanes com o auxílio de uma ponte construída na década de 1680 e seguiam por um percurso relativamente tranquilo e plano. ${ }^{9} \mathrm{~A}$ proteção dos viandantes era garantida pelos soldados que costumavam acompanhar as boiadas, evitando assaltos e possíveis desvios de algumas reses que cismassem em frequentar os "des-caminhos". Como foi lembrado no primeiro capítulo, nos anos iniciais de funcionamento da feira de Capuame, eram os soldados do Terço de Henrique Dias os militares responsáveis por guardar os comboios. ${ }^{10}$ Alguns criadores e condutores também faziam este mesmo trajeto para encaminhar o gado que traziam dos sertões baianos quando conseguiam uma licença dada pelos funcionários da Câmara Municipal para cortar por conta própria a carne nos açougues espalhados pela cidade, sem o intermédio dos marchantes. ${ }^{11}$ Atravessando as partes suburbanas do termo da cidade de Salvador, seguiam marchantes, criadores e os demais trabalhadores responsáveis pelo abastecimento através da estrada das Boiadas até chegarem na Campina do Pirajá. ${ }^{12}$

No século XIX, além dos registros de entrada de gado estabelecidos em Cajueiro, Lagoinhas, Saco de Moura, Serrinha, Tamboatá, Santana e Capuame foi criado um outro ponto de fiscalização no sítio da Campina do Pirajá. A ideia era impedir que passasse pela região qualquer boi que não tivesse sido registrado em Capuame. As imediações do novo registro dava acesso a São Caetano, Ribeira e arredores (próximo das igrejas de Nosso Senhor do Bonfim e Monserrath), conhecidos pela ocorrência de pastos clandestinos e matadouros ilegais. ${ }^{13}$ Em Campina do Pirajá os responsáveis pela condução das boiadas permaneciam por um dia em cômodos de hospedagem para possibilitar o descanso do gado antes de chegar nos muros da cidade. $O$ registro estabelecido em terras do Conselho Municipal contava não só com os locais destinados ao pouso e parada dos agentes envolvidos no trabalho de encaminhamento dos rebanhos, mas também com um pasto especial para acolher as cavalgaduras dos condutores, marchantes e soldados ${ }^{14}$. Segundo Richard Graham, a região era constantemente vigiada por três guardas que faziam a ronda no local. ${ }^{15}$

Aos sábados pela madrugada continuavam a viagem com destino ao matadouro público, acompanhados com uma guia - uma espécie de

\footnotetext{
9. AMS. Cartas Do Senado (1673-1684), volume 2, 15 de julho de 1679, p. 62.

10. APEB. Maço 151. Carta do Governo (à várias autoridades) 1730-1734. Carta do Capitão Luis Pereira, 16 de abril de 1731.

11. Foi mencionado nos outros capítulos a decisão de dar direitos aos criadores e condutores de cortar por conta própria carne das reses por eles encaminhadas.

12. AMS. Posturas Municipais (1829-1859), Título 3 artigo 66 Parágrafo 7,8,9,10 da lei de 1 de outubro de 1828.

13. DH."Portaria para o Meirinho Antônio Botelho " 10 de dezembro de 1734. vol. 76. p. 23; DH.

"Portaria para o Meirinho Sebastião de Ávila Vareiro" 26 de novembro de 1734. vol. 76. p. 37.

14. AMS. Posturas Municipais (1829-1859), Título 3 artigo 66 Parágrafo 7,8,9,10 da lei de 1 de outubro de 1828.

15. Richard Graham, op. cit., p. 195.
} 
documento assinado pelas autoridades responsáveis pelos registros de entrada de gado pelos quais as boiadas tinham passado durante o extenso trajeto percorrido das unidades produtivas até chegarem à feira de Capuame. Na guia ficava marcado o número de reses de cada um dos rebanhos e o nome do responsável pela condução. Em cada um dos registros, o seu respectivo administrador conferia o número de cabeças de gado que passava e comparava com a informação escrita. A quantidade deveria ser exatamente igual, exceto para os bois ou vacas que morressem nos caminhos. Mesmo as reses mortas deviam ser registradas em livro de ocorrência separado, contendo justificativa com depoimento de testemunhas que juravam com as mãos sobre o Evangelho. ${ }^{16}$

Os bovinos com destino ao abastecimento de Salvador chegavam no local de abate sábado pela manhã. O matadouro público mudou algumas vezes de lugar. Do início do século XVIII até a década de 1830, localizava-se na região das Portas de São Bento ${ }^{17}$, uma das extremidades da cidade fortificada, próximo a Igreja da Barroquinha. Todos os restos de sangue corriam em direção ao córrego que passava na parte de trás do matadouro público, apelidado na época pelo sugestivo nome de rio das Tripas. Foi canalizado em finais do século XVIII, passou a chamar-se Rua da Vala, depois conhecida como a Baixa dos Sapateiros. ${ }^{18}$ No matadouro público trabalhavam os escravos carniceiros responsáveis por matar as reses, tirar cuidadosamente o couro, separar as entranhas e vísceras, limpar todo o animal, cortar os talhos e repartir por arroba. ${ }^{19}$ Era necessário abundância de água corrente não só para jogar nos talhos cortados como também para limpar o chão e outros utensílios utilizados no procedimento. A matança ocorria todos os sábados das nove da manhã às quatro horas da tarde, exceto na Semana Santa.

No século XIX, o matadouro público foi transferido para os arredores do Forte do Barbalho devido principalmente à preocupação das autoridades quanto à salubridade da população. Se entre os séculos XVII e XVIII as Portas de São Bento era uma das entradas da cidade fortificada e mostrava-se com um limite até mesmo para a ocupação primitiva do sítio da primeira capital; com o aumento populacional, a região já não se encontrava mais tão isolada e o matadouro passou a fazer parte do perímetro povoado da região. $\mathrm{O}$ forte cheiro - agravado nos períodos de seca e muito calor - e a quantidade de moscas e insetos - que costumam estar presentes onde há carne e sangue dos animais $^{20}$ - certamente foi um dos motivos da transferência.

\footnotetext{
16. AMS. Livro de "Justificação de reses mortas" (1791-1811) sub-secção: Matadouro.

17. Rodrigo Freitas Lopes. Nos currais do matadouro público. O abastecimento de Salvador no século XIX (18301873). UFBA, Salvador, 2009, p. 14.

18. Luís Eduardo Dórea. Os nomes das ruas contam histórias. Salvador, 1999, p. 87 e 95

19. AMS. Atas da Camara (1700-1718). 15 de fevereiro de 1703 . vol. 7, p. 139-140.

20. Já em 4 de março de 1673 foram elegidos dois almotacéis para andarem pelos arredores dos currais para garantir a limpeza e salubridade do rebanho. AMS. Cartas Do Senado (1638-1673), vol. 1, p. 117.
} 
Ao que tudo indica, as autoridades já tinham planos de mudar o lugar do matadouro desde as últimas décadas do século XVIII. Interessante o testemunho de um documento escrito em 1784 retratando as preocupações do Senado da Câmara em achar um sítio conveniente para abrigar o curral do Conselho e o matadouro público. Foram analisados quatro lugares distintos. O primeiro deles (e o mais conveniente na época) eram as terras próximas ao Dique do Desterro ${ }^{21}$. Bem atrás dos muros do convento das freiras do Desterro, era um local possuidor de muitas comodidades para abrigar o novo matadouro: tratava-se de um sítio "lavado dos ventos", sua elevação permitia uma circulação favorável do ar, bem localizado, extenso, com bom terreno e declividade propícia para facilitar a implementação de "escoadouros", possivelmente destinada a fazer escorrer o sangue em direção a lagoa localizada na parte baixa do Dique.

De todos os terrenos observados (sendo os outros três localizados na região do Campo do Barbalho) aquele era o melhor. Mas logo surgiram os inconvenientes: primeiramente a região do Dique abastecia de água doce grande parte dos poços cavados nas residências da região. O sangue das reses certamente contaminaria o solo, o lençol freático, os rios e o próprio lago do Dique. Evidentemente as freiras do opulento convento do Desterro não ficaram nada contentes com a notícia da possível criação de um matadouro bem atrás de suas terras. Trataram logo de reclamar e deixar evidente a insatisfação, servindo de freio para as autoridades que temiam recorrer no mesmo erro de quando os currais estavam na região de "Santo Antonio". Por fim, a última palavra sobre o local de estabelecimento do novo matadouro público ficou a cargo do "exame ocular dos professores médicos". 22 Os especialistas teriam de visitar todos os sítios escolhidos para abrigar o futuro matadouro e escolher qual era o mais adequado. Ao que tudo indica, as autoridades no assunto deram um parecer negativo, sendo escolhido décadas depois um dos três terrenos da região dos campos do Barbalho.

Em relação ao primeiro matadouro público estabelecido nas Portas de São Bento, os campos do Barbalho estavam na outra extremidade da cidade. Mais próximo da estrada das boiadas, ficando anterior à freguesia de Santo Antônio Além do Carmo, na perspectiva de quem vinha do interior da Bahia sentido a capital de Salvador. Ficava na região mais periférica da cidade que não parava de crescer mesmo depois de deixar de ser capital da colônia. Desde o século XVIII, os campos do Barbalho já eram povoados de currais nos quais os bois pastavam aguardando o momento de serem abatidos. Ao que tudo indica a existência de currais em Salvador não era problema no período setecentista. As atuais praças da Piedade, Largo do Campo Grande, os bairros de Barris e Cabula também eram currais do Conselho. ${ }^{23}$

\footnotetext{
21. A região do Dique era conhecida no final do século XVIII como Dique do Desterro. Atualmente denomina-se Dique do Tororó.

22. APEB. Correspondência recebida pelo governo Senado da Camara da Bahia (1783-1799). Maço 201-14. 3 de abril de 1784, fl. 2

23. Rodrigo Freitas Lopes. op. cit.
} 
O novo matadouro público, construído nas primeiras décadas do século XIX, possuía piso de ladrilhos para facilitar a limpeza, teto alto e um grande portão por onde entravam 30 animais de cada vez. A inclinação do piso era tal que o sangue escorria totalmente para o centro do edifício, onde havia um escoadouro conectado a um tanque de captação localizado na parte externa do matadouro, facilitando o asseio do local. ${ }^{24}$ Mas em 1873 foi desativado, mudando definitivamente para o Engenho Retiro, local estrategicamente escolhido por tratar-se de uma região mais distante da parte ocupada da cidade. A decisão de mudar o matadouro para o Engenho Retiro já era antiga, mas a medida foi protelada por disputas judiciais entre os herdeiros do Engenho. ${ }^{25}$

\section{$* *$}

Depois do abate dos animais no matadouro público, os talhos de carne verde seguiam para os açougues espalhados pela cidade. A condução do alimento ficava a cargo dos marchantes que tinham o dever de garantir o constante fornecimento de carne verde aos açougues. O transporte era feita no lombo de cavalos e burros ou nas costas dos escravos que trabalhavam para os negociantes de gado. Tanto os cavalos quanto os escravos percorriam a cidade com os talhos expostos, utilizando no máximo uma cobertura de couro para garantir o mínimo de contato da carne fresca com qualquer fonte possível de contaminação. ${ }^{26}$ Em carta ao governador, os funcionários da Câmara Municipal denunciavam a falta de cuidado com que os talhos eram transportados depois de cortados. Apodreciam facilmente após ficarem horas expostos ao sol, à chuva e ao tato dos cavalos e escravos carniceiros. Isso quando não caiam escandalosamente pelas vias públicas derrubando as carnes " sobre as lamas e imundices". ${ }^{27}$ Exageros à parte, o fato é que os escravos carniceiros estavam submetidos a carregar os pesados talhos nas costas de modo totalmente descuidado e despreparado, interferindo diretamente na qualidade do alimento destinado à população em geral.

Devido ao trabalho pesado que o corte, manejo e condução da carne exigia, já era de se esperar que os homens livres se recusassem sistematicamente em exercer tal ofício. ${ }^{28} \mathrm{O}$ único episódio em que homens livres apareceram como trabalhadores do matadouro foi durante a greve de 1830, momento no qual os escravos foram substituídos por trabalhadores assalariados para forçar o retorno das atividades do matadouro. ${ }^{29}$ Os escravos carniceiros, os fábricas dos matadouros e açougues, aparecem com certa frequência nos documentos (não raras vezes) sendo culpabilizados por participação em contrabando e furto de carne. A partir de 1736, os escravos carregadores que roubassem quartos da carne transportada pelas ruas da

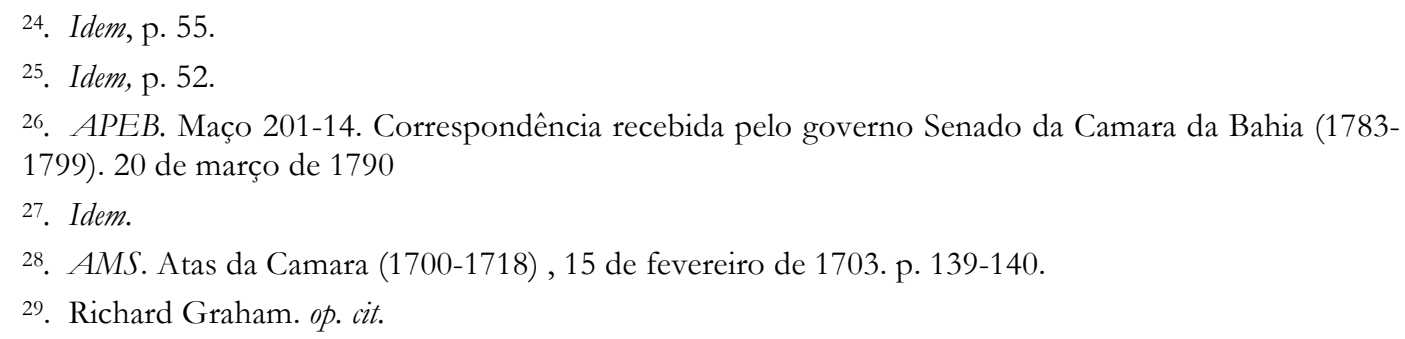


cidade passariam a ser açoitados publicamente na porta da Alfândega, onde o provedor colocou "um madeiro grosso à imitação de coluna " para essa finalidade. Segundo as autoridades, a violência corporal tinha um propósito pedagógico: após o momento em que esse tipo de castigo passou a ser executado, os roubos pararam de ocorrer pois os negros temiam mais o açoite em local público do que "a prisão ou enxovia para onde eram levados ". 30

Em 1687, o juiz do povo Antonio de Magalhães fez um requerimento pedindo para que os marchantes fossem notificados e proibidos de empregar negros, mulatos ou soldados no ofício de cobrar o dinheiro referente a compra da carne nos açougues públicos. A proibição devia-se a quantidade de reclamação dos fregueses que se viam obrigados a lidar semanalmente com esta gente de infima plebe, homens "sujeitos contra o povo". O juiz do povo solicitava que os responsáveis pelo açougue tivessem o mínimo de bom senso para contratar alguém "decente e todos de sã consciência", pois o funcionário encarregado de cobrar o dinheiro recebia o valor de $60 \$ 000$ réis anuais do Senado e deveria se portar e ter qualidades compatíveis ao ofício exercido. Determinava que os almotacéis e demais juízes fossem obrigados a assistir semanalmente aquele espaço para notificar qualquer tipo de irregularidade. $\mathrm{O}$ mesmo requerimento alertava aos responsáveis pelo açougue sobre a necessidade de " dependu[ra]rem a carne pelas pernas para escorrer o sangue e não pelas costelas assim nos currais como nos açougues com a pena de que todas as vezes que se achar dependurada pelas costelas será pago o que tiver mandado matar". ${ }^{31}$ Depois de 1700 o cobrador do açougue passou a ser um cargo eleito com critérios estipulados diretamente pelos funcionários da Câmara. ${ }^{32}$ Por falta de opção melhor, no ano de 1703 foi nomeado o degredado João de Oliveira para o cargo de cobrador do dinheiro do açougue. Não que em situações ideias fosse vontade das autoridades competentes eleger alguém que já possuísse o estigma de perseguido e desonrado, mas não havia escolha: os outros candidatos foram imediatamente descartados por serem soldados, artilheiros e mulatos cativos. Pelo menos o reinol, apesar de ter cometido algum possível delito, sabia ler e escrever. ${ }^{33}$

Não se sabe ao certo por qual motivo, mas muitos documentos apontam a falta de simpatia dos funcionários municipais em relação aos militares de mais baixa patente. Fora um evidente preconceito quanto a origem social da maior parte dos soldados rasos recrutados "na marra" durante o período colonial, ${ }^{34}$ havia um fundo de veracidade nas narrativas que deixaram registradas o descontentamento dos homens da elite em relação aos militares que deveriam esquecer temporariamente a sua própria condição material precária para obedecer prontamente as ordens de seus superiores. Talvez com

\footnotetext{
30. DH. 20 de outubro de 1736. vol. 91. p. 64.

31. AMS. 24 de março de 1687. p. 80. Atas da Camara (1684-1700), p. 6.

32. AMS. Atas da Camara (1700-1718), vol. 7, 23 de março de 1700, p. 15

33. AMS. Atas da Camara (1700-1718), vol. 7. "Termo de vereação e eleição de jurado" 14 de março de 1703. p. 148.

34. Kalina Vanderlei P. Da Silva. O miserável soldo \& a boa ordem da sociedade colonial. Militarização e marginalidade na Capitania de Pernambuco dos séculos XVII e XVIII. UFPE, Recife, 1999.
} 
base em alguns dados e casos concretos - pautados na experiência vivenciada pelos habitantes da cidade - as elites e setores médios da sociedade colonial criaram todo um estereótipo de soldados desqualificados e desordeiros sempre indignos de muita confiança. Se fossem homens de cor, a situação tornava-se ainda mais grave. Esta visão foi relatada no caso dos soldados do Terço dos Henrique Dias que foram substituídos por militares brancos para vigiar a feira de Capuame. ${ }^{35}$

No dia 4 de abril de 1795, em meio a um dos muitos períodos de falta pontual de carne verde para abastecer a população, o açougue da praça foi invadido por homens que tomaram os talhos com o uso da força, picaram a carne, roubaram uma parte do alimento e venderam a outra parte à população. Os responsáveis foram prontamente encarcerados. Todos eles militares de baixa patente: os cabos da esquadra José Xavier e Santarém e os soldados José Telles, Vicente de Sal e Simões (do Regimento Velho); soldado Francisco Geraldo (do Regimento Novo); soldado Coitinho e o meirinho da Relação Francisco Simões da Costa (do Regimento de Artilharia). ${ }^{36}$

Em momentos de descontentamento, a população não exitava em agir diretamente contra o ponto ou pessoa que julgavam ser o causador de todos os males enfrentados. ${ }^{37} \mathrm{~A}$ região suburbana de Itapagipe possuía um açougue desde o início do século XVIII. A medida foi tomada em respeito ao pedido dos moradores que já somavam um número avultado e tinham muita dificuldade para se deslocarem até as portas da cidade toda vez que necessitassem comprar carne verde. Possivelmente não foi única e exclusivamente a vontade da população que contou na hora de atender o pedido dos moradores e montar um açougue na região. Itapagipe ficava nos arrebaldes da cidade, cercada por terrenos baldios propícios para o corte clandestino de carnes. Avizinhava-se das terras já apontadas como espaço de matança ilegal dos rebanhos. A proximidade com o mar, que também alimentava os habitantes (formados em grande parte por pescadores), certamente facilitava o contato com a carne contrabandeada que vinha em pequenas embarcações. ${ }^{38}$ No ano de 1718 os arrematadores do contrato que gerenciava o açougue de Itapagipe deixaram os moradores descontentes: decidiram, sem consultar ninguém (inclusive os funcionários municipais), mudar o estabelecimento antes fixado na parte chamada "Posto dos pescadores de Itapagipe", ponto movimentado e de grande circulação dos habitantes, localizado na beira da praia, alterado para um lugar mais distante denominado sítio da Olaria. Com medo do descontentamento da população gerar algum tipo de desavença ou motim, os arrematadores foram intimados

\footnotetext{
35. APEB. Maço 151. Carta do Governo (à várias autoridades) 1730-1734. Carta do Capitão Luis Pereira, 16 de abril de 1731.

36. APEB. Maço 201-14. Correspondência recebida pelo governo. Senado da Camara da Bahia (17831799). 8 de abril de 1795 .

37. Esta perspectiva tem semelhança com o diagnóstico feito por Edward P. Thompson. "Economia moral da multidão inglesa no século XVIII." Costumes em comum. Estudos sobre a cultura popular tradicional. São Paulo, 1991.

38. APEB. Maço 485-2. Senado da Camara de Salvador Correspondência recebida (1786 - 1822), fl. 13.
} 
rapidamente pelos funcionários da Câmara e tiveram o prazo de uma semana para retornar ao local original e pôr tudo funcionando novamente. Se assim não fizessem, ficariam presos por 30 dias na cadeia pública e teria de pagar uma multa. ${ }^{39}$

É curioso perceber que a quantidade e a espacialidade da distribuição dos açougues soteropolitanos mantinha uma determinada sincronia em relação as conjunturas históricas e acompanhava o próprio crescimento da cidade. $\mathrm{O}$ número de açougues mudou muito no decorrer do século XVIII. Os primeiros açougues foram certamente aqueles estabelecidos perto das duas entradas principais da cidade: a porta do Carmo e a porta de São Bento. Mencionados desde metade do século XVII, provavelmente eram os mais tradicionais e movimentados mesmo depois da criação de outros pontos de comércio. Estavam localizados cada qual em uma das extremidades do muro que cercava a parte alta da cidade composta pelos principais edifícios administrativos e eclesiásticos da antiga capital.

Os currais, matadouro e açougues eram todos administrados por terceiros. Apesar de ser competência da municipalidade garantir e legislar sobre o abastecimento necessário para a manutenção da cidade cindida, em várias localidades os vereadores preferiam delegar à outrem todos os pormenores e a execução da tarefa de encaminhar os alimentos até os centros urbanos. Isso ocorria tanto em Salvador e Rio de Janeiro como em Évora e Lisboa. ${ }^{40}$ Este fornecimento era garantido através de contratos firmados com particulares, ou seja, a Câmara Municipal abria uma licitação pública para escolher quem seria o grande responsável pela tarefa de conduzir alimentos para a população e administrar os espaços de abate e comercialização da carne. Os interessados davam um lance a arrematavam o contrato. ${ }^{41}$ Os livros contendo os termos dos contratos de arrematação restantes no Arquivo Municipal de Salvador começam no ano de $1665 .{ }^{42}$ As informações anteriores a esta data não foram localizadas, e mesmo para os livros restantes há muitas partes ilegíveis ou já bem consumidas pelo tempo, sendo difícil um levantamento sistemático das informações constantes em todos eles. O conteúdo dos termos também é de difícil mapeamento por fazerem referências "as mesmas condições do ano passado" sem especificar quais eram.

Daquilo que ainda foi possível observar através dos manuscritos, os contratos eram firmados anualmente, estabelecidos após a arrematação feita em praça pública, em frente a Casa da Câmara. Assim que o maior lance fosse dado e o pregão terminado, o arrematador levantava um ramo verde (assumindo a parte ritualística do acordo). Os arrematadores precisavam ter

\footnotetext{
39. AMS. Atas da Camara (1718-1731), vol. 8, 16 de dezembro de 1718, p. 17.

40. Georgia da Costa Tavares. A atuação dos marchantes no Rio de Janeiro Colonial: estratégias de mercado e redes de sociabilidade no comércio de abastecimento de carne verde (1763-1808). Rio de Janeiro, 2012 ; Rui Santos. "Mercados, poderes e preços: a marchantaria em Évora ( séculos XVII-XIX)". Penélope, 21, 1999: 6393.

41. Sobre as rendas municipais e o próprio funcionamento dos contratos, ver: Avanete Pereira Sousa. Poder local, cidade e atividades econômicas (Babia, século XVIII). USP, São Paulo, 2003.

42. AMS. "Arrematação das Rendas da Camara" (1665-1884). 20 vol. Seção: Tesouro.
} 
um fiador e vencia aquele que garantisse o maior retorno financeiro à Câmara Municipal de Salvador, mas cobrasse o menor preço possível pela carne. O valor do contrato era pago em dinheiro de contado em moeda corrente. $\mathrm{Na}$ arrematação do Curral das Bandas de São Bento feita no dia 23 de março de 1667 venceu o pregão dos sócios e parceiros Manoel Rodrigues e Afonso Gomes Ventosa. Tinham por fiador o mercador de sobrado Manoel de Oliveira Porto, morador em Salvador e deviam pagar o valor de $320 \$ 000$ aos funcionários da Câmara. Comprometiam-se a pagar 13 vinténs por cabeça para os criadores e donos das reses. Eram obrigados a dar todo o serviço necessário de negros e mais fábricas aos criadores de gado para cortarem as carnes. ${ }^{43}$ Curioso perceber que os contratos de arrematação eram estabelecidos sempre na época que antecedia a Páscoa, possivelmente na Quaresma. Voltaremos a este assunto.

Havia na segunda metade do século XVII duas arrematações distintas: arrematação do curral do Carmo e a arrematação do curral do conselho da Banda de São Bento. Cada um referente a um dos currais responsáveis por cortar a carne abastecedora de cada um dos açougues. O termo do contrato de arrematação do curral do conselho da Banda de São Bento de 1665 determinou que o valor a ser pago à Câmara era de $350 \$ 000$ pelo direito de cortar e comercializar os talhos de carne verde. Neste mesmo lugar seriam cortadas a carne destinada ao talho da Santa Casa de Misericórdia. ${ }^{44}$ O termo talho era utilizado para designar uma espécie de divisão ou repartição interna dos açougues. ${ }^{45}$ Ao que tudo indica, os arrematadores podiam conceder alguns talhos a outros marchantes que ficavam encarregados de colocar ali a carne que traziam de Capuame semanalmente. Pouco se sabe sobre os acordos firmados entre os arrematadores e os marchantes quanto a distribuição dos talhos. Aos criadores também era dado o direito de receberem dos arrematadores os talhos específicos caso tivessem autorização da Câmara Municipal para cortar por conta própria as reses que trouxessem dos sertões baianos, retirando o intermédio dos marchantes.

Por muitos anos os irmãos da Santa Casa de Misericórdia mantiveram um açougue próprio para poderem cortar exclusivamente a carne destinada ao consumo tanto da instituição quanto dos membros da irmandade. Foi concedido no século XVII como uma forma de privilégio por manterem o funcionamento do Hospital Real da Bahia. Todavia, a partir de 1706 parece haver uma série de conflitos entre os irmãos da Santa Casa de Misericórdia e a Câmara Municipal que pretendia revogar a qualquer custo o privilégio outorgado pelo rei.

"[Os irmãos da Santa Casa] pediam fossem conservados na posse em que estavam de ter açougue público em casa particular [...] visto estarem os suplicantes [irmãos da Santa Casa] de posse tão antiga do seu açougue com é notório tendo-o em casa

\footnotetext{
43. AMS. "Livros de Arrematação das Rendas da Câmara". Vol.1, 23 de março de 1667.

44. Idem.

45. AMS. Atas da Camara (1700-1718) "Termo de vereação e de resolução que se tomou sobre os talhos dos desembargadores." vol. 7,16 de maio de 1703. p. 161.
} 
separada sem nunca ser arrendado por este Senado e outrossim ser a renda do dito açougue aplicada como outra mais para a criação dos enjeitados." ${ }^{46}$

Possivelmente tal conflito se prolongou por décadas. Para 1732 localizamos um documento citando uma consulta ao Conselho Ultramarino sugerindo aos funcionários da Câmara Municipal de Salvador que, caso eles insistissem em proibir de fato a existência do Açougue da Misericórdia, seriam obrigados a doar $200 \$ 000$ réis para o Hospital Real da Bahia. Esse valor deveria ser retirado da parte que cabia ao município do valor total arrecadado pelo donativo da carne com o objetivo de bancar os custos e cuidados com os enjeitados e enfermos que eram mantidos pelos irmãos da Santa Casa de Misericórdia. ${ }^{47}$ Pelo menos era isso que os suplicantes afirmavam.

Além dos açougues e talhos públicos espalhados por Salvador, temos a indicação da existência do açougue dos Eclesiásticos até pelo menos meados do século XVIII. Motivo de discórdia e querelas que se arrastaram por quase treze anos opondo o poder secular ao poder eclesiástico, o caso fora estudado por Camila Teixeira Amaral em "As duas Espadas do Poder". Segundo a historiadora, desde 1620 os eclesiásticos já possuíam um açougue próprio. ${ }^{48}$ Isso funcionava como uma espécie de distinção social em relação ao restante da população que se amarrotava e estapeava por um pedaço de carne no amontoado e abafado açougue público. Religiosos e autoridades régias passaram por inúmeras desavenças que iam desde debates quanto ao início da cobrança de imposto sobre a carne comercializada no Açougue dos Eclesiásticos até a tentativa de fechamento e retirada do "talho do senhor Bispo" do Açougue Público. ${ }^{49}$ Tudo isso porque havia um conflito de interesse no que tangia o controle da Câmara Municipal de Salvador sedenta em manter a observância sobre a fonte da maior parte de seus rendimentos. Já era antiga a queixa quanto ao hábito dos religiosos de infringirem leis como a proibição de comprarem e possuírem bens de raiz tais como engenhos e fazendas de gado, além de serem isentados de todos os tipos de dízimos, agravando as finanças da municipalidade. ${ }^{50}$

Os desembargadores do Tribunal da Relação também contavam com um talho específico para cortarem a carne que consumiam. Assim como no caso dos Eclesiásticos e Irmãos da Santa Casa de Misericórdia, a licença foi dada pelo rei. Foi acertado que os desembargadores teriam de pagar uma quantia anual para a Câmara Municipal para manterem o privilégio. O talho não era arrematado como os demais: o administrador do ponto de corte e comércio exclusivo era nomeado diretamente pelos privilegiados. O administrador, por

\footnotetext{
46. AMS. Atas da Camara (1700-1718). "Termo por onde se concedeu o açougue Misericórdia"11 de agosto de 1706. vol. 7, p. 298.

47. DH. 9 de junho de 1734. Vol. 91, p. 23. .

48. Camila Teixeira Amaral. As duas Espadas do Poder: As relações de tensão e conflito entre o poder secular e o poder eclesiástico na Babia (1640-1750).USP, Salvador, 2012.

49. AMS. Atas da Camara (1700-1718).“Termo de vereação e fé do porteiro João da Silva Fernandes sobre trazer na praça o talho do senhor bispo que o tem por ordem de Sua Majestade, fora do açougue público."16 de novembro de 1709. vol. 7, p. 399.
}

50. AMS. Cartas Do Senado (1638-1673), volume 1, p. . 54. 
sua vez, deveria pagar a quantia anual de 150 mil réis para os funcionários municipais pelo direito. A taxa cobrada era de 12 réis e meio pela libra da carne. ${ }^{51} \mathrm{Em}$ 1674, as intromissões dos desembargadores nos negócios de Senado geraram mau estar entre as partes, chegando os oficiais a escrever carta diretamente ao rei para garantir que os desembargadores não mais interferissem nas repartições dos talhos e nem usassem o seu privilégio para priorizar o corte de seu gado em detrimento daquele encaminhado pelos criadores que se viam diante de perdas incalculáveis. ${ }^{52}$ Quatro anos depois as rixas foram retomadas devido a tentativa da Câmara em aumentar o valor do contrato do talho. O doutor Antonio Nabo Peçanha, enquanto representante dos desembargadores, recusava-se a aceitar a alteração do valor estipulado inicialmente. Os funcionários municipais, por sua vez, alegavam a defasagem e o prejuízo no recolhimento do valor que deveriam enviar como parte da terça de Sua Majestade para justificar o pedido do fim do privilégio. Propunham que o talho dos desembargadores fosse posto em arrematação pública, como era feito com os açougues públicos e eclesiásticos. ${ }^{53} \mathrm{Em} 1703$ os desembargadores entraram em litígio com os vereadores por requererem que o talho a eles concedido fosse retirado do açougue da cidade. Queixavam-se dos incômodos e dificuldades sofridas por seus serventes na hora de comprar o alimento no tumultuado prédio público. Pediam a licença de concederem ao rendeiro a oportunidade de alugar um outro estabelecimento fora daquele para funcionar separadamente o talho de homens tão ilustres. Depois de muita discussão, ficou a promessa de solicitarem licença diretamente ao rei por correspondência enviada na próxima frota com destino à Metrópole. ${ }^{54}$

Autonomia da Câmara nos assuntos condizentes à municipalidade e abastecimento? Sobreposição de interesses e circunscrições? $\mathrm{O}$ fato é que o controle exercido pela Câmara esbarrava cotidianamente na estrutura social herdada da metrópole. Diante das inúmeras concessões e mercês feitas pelo rei para manter em contento a elite colonial responsável por reproduzir a lógica de dominação no além-mar, restava aos representantes da Câmara Municipal de Salvador recorrer às intermináveis instâncias, consultas e pareceres sobre os assuntos mais variados com o objetivo de garantir o controle que lhes cabia sobre determinados assuntos tais como a comercialização de carne verde. Muitas vezes os esforços eram em vão. Quando a interferência chegava em seu limite, a única alternativa que tinham era apelar para o teoricamente convincente argumento da redução do valor arrecadado pela Casa da Câmara, resultando em uma diminuição da receita da principal cidade da América Portuguesa e maior contribuidora para as terças enviadas anualmente à Sua

51. AMS. Atas da Camara (1669-1684). "Termo de ajustamento que fizeram os oficiais da Camara com o Doutor Antonio Nabo Peçanha sobre talho dos Desembargadores.” , vol. 5, 4 de março de 1676, p. 182.

52. AMS. Cartas Do Senado (1673-1684), volume 2, 1 de setembro de 1674, p. 31.

53. AMS. Atas da Camara (1669-1684), vol. 5 "Traslado de um protesto que fez o procurador do Conselho Manoel da Silva Matos sobre o talho dos desembargadores". 25 de fevereiro de 1679, p. 248.

54. AMS. Atas da Camara (1700-1718). "Termo de vereação e de resolução que se tomou sobre os talhos dos desembargadores." Vol. 7, 16 de maio de 1703. p. 161. 
Majestade. Mas ao que tudo indica o pretenso argumento convincente não bastava para mudar o posicionamento dos membros do Conselho Ultramarino. Para manter as hierarquias e distinções reguladoras da sociedade colonial mais valia agradar aos "homens bons". Não que os vereadores não os fossem. Privilégios eram mantidos à mercê das finanças que se arrastavam diante de obrigações monetárias mais onerosas do que o total arrecadado, resultando no constante atraso do pagamento das terças reais que precisavam ser emitidas anualmente junto com as Naus com destino à Lisboa. ${ }^{55}$

Não se sabe até quando foi concedido licença para os desembargadores manterem um talho específico, o certo é que os privilégios e a reprodução das distinções sociais como mecanismo regulador da colônia não tinha limites. Em 1694, os senadores decidiram por proibir terminantemente a venda de quartos de carne diretamente nos currais, exceto para os representantes ou empregados do governador. Tudo isso porque muitos membros da elite recorriam ao seu poder, influência e privilégio para comprar a carne logo após o abate, antes de serem encaminhados para os açougues, escolhendo os melhores pedaços e ficando somente para o restante da população as partes dianteiras dos bovinos. Este hábito já não era mais permitido inclusive na praça de Lisboa ${ }^{56}$, mas muitos colonos cismavam em reforçar a seu status até mesmo na hora de comprar um pedaço de carne que acabava se tornando quase uma artigo de luxo dependendo da qualidade do corte.

Para o extremo oposto da pirâmide social, as tarefas mais cotidianas se davam de uma outra maneira. Em 1653, é possível observar a indicação da existência de quatro talhos em Salvador, contando com um destinado exclusivamente aos "soldados livres sem pensão" 57. Possivelmente eram os homens de mais baixa patente e de poucos recursos envolvidos com a guerra contra os holandeses que precisavam ao menos ter garantido o acesso ao alimento básico da dieta colonial, visto os recursos municipais nunca serem o bastante para pagar os ex-combatentes. Esta não era evidentemente uma prioridade. A proposta dos vereadores em sessão de 16 de novembro de 1669 demonstra a dificuldade em manter financeiramente os dois terços da cidade. A possibilidade de extinção de pelo menos um dos dois agrupamentos militares se devia ao aumento da inviabilidade de arcarem com os 29 mil cruzados necessários para manter os 187 oficiais maiores e os 921 soldados, na medida em que metade deles encontravam-se inválidos. ${ }^{58} \mathrm{~A}$ informação sobre o açougue destinado aos soldados inválidos não voltou a aparecer nos documentos, podendo tratar-se portanto de uma medida pontual e efêmera para resolver o problema dos pagamentos ou para funcionar como algum tipo de auxílio mínimo devido aos combatentes que (não raras vezes) ficavam sem

\footnotetext{
55. AMS. 8 de outubro de 1729, p. 139, vol. 7.

56. AMS. Atas da Camara (1684-1700), "Termo de vereação e resolução que tomaram os oficiais da Camara sobre se não vender nos currais quarto de carne a pessoa alguma de qualquer condição que seja excetuando somente comprador do senhor governador.", vol. 6, 9 de junho de 1694. p. 247.

57. AMS. Atas da Camara. (1649-1659) . "Termo de Contrato que se fez com os marchantes Noitel Rodriguez Domigos da Costa, Estevão Faleiro, Domingos Fernades, Francisco Vergella sobre se obrigarem a dar carne ao povo." 11 de março de 1653. vol 3. p. 237.

58. AMS. Cartas Do Senado (1638-1673), volume 1, 16 de novembro de 1669, p. 84.
} 
qualquer tipo de recebimento ou ajuda (mesmo quando inválidos para o trabalho necessário para o sustento da família). ${ }^{59}$

Trinta anos depois, a cidade já contava com oito talhos públicos. ${ }^{60} \mathrm{O}$ cenário mudou consideravelmente no decorrer do século XVIII quando a cidade ganhou uma nova configuração com a vinda de sem número de imigrantes europeus e africanos escravizados, desembarcados aos montes no movimentado porto da Bahia de Todos os Santos. A multiplicação do número de talhos espalhados pela cidade, a mudança constante do local dos açougues são exemplos desta dinâmica de abastecimento com necessidade crescente de carne para alimentar a população da primeira capital da América Portuguesa.

Segundo Avanete Pereira Sousa, em Poder local, cidade e atividades econômicas, durante o século XVIII havia cerca de dez açougues espalhados pela cidade. Este número foi aumentando conforme crescia a população e a simultânea necessidade de mais pontos de comércio de carne em Salvador. Brotas, Itapagipe, Cabula, Soledade, Freguesia da Praia, Baixa dos Sapateiros, Mares, Penha, Vitória, Carmo e São Bento são alguns dos açougues mencionados. ${ }^{61}$

Nos "Livros de Registro de Entrada de Gado" da feira de Capuame destinados aos anos de 1784- 1789 '62 há referências às "Faculdades", ou seja, a cada uma das "Casas dos Talhos" espalhadas pela cidade. No açougue, o talho era o local onde a carne bovina cortada e distribuída era comercializada, sendo inclusive, segundo Bluteau, utilizado o termo talho como mero sinônimo de açougue. Vale lembrar que talho também era o nome dado ao tipo de corte do gado vaccum. ${ }^{3}$ Os locais indicados foram Santa Bárbara, Baixa dos Sapateiros, Brotas, Machado e Cursino, Soledade, Mercês, Cabeça, Preguiça. No entanto, tal referência às "Faculdades" só passou a ser feita a partir da feira de 20 de junho de 1787 , denotando que a partir daquela data, o marchante já saía da feira de Capuame tendo o destino certo para a carne que cortariam no matadouro. Só não foi possível até o momento saber como era feita a divisão e como escolhiam qual marchante encaminharia carne para qual açougue. ${ }^{64}$ Ao que tudo indica, com o passar do tempo, os marchantes receberam o direito deles mesmos arrematarem alguns talhos. Trataremos deste assunto mais adiante.

Interessante reparar a preocupação recorrente a partir dos "Livros de Registro de Entrada de Gado" de 1801-181165 quanto ao destino que a carne tomava em Salvador. Isso não aparece do mesmo modo nos livros anteriores. Neste documento é possível observar que o período exigia mais atenção ao local para onde a carne seria encaminhada depois de cortada no matadouro.

59. A mesma situação parece ser um problema para a capitania de pernambuco pós-guerra dos holandeses. Kalina Vanderlei P. da Silva. op. cit., p. 141.

60. AMS. Atas da Camara (1669-1684). 20 de março de 1683. vol. 5 p. 347.

61. Avanete Pereira Sousa. op. cit., p. 212.

62. AMS. "Livro de Registro de Entrada de Gado" (1784-1789)

63. Raphael Bluteau. Vocabulário Português e Latino, vol. 8, p. 26.

64. AMS. "Livro de Registro de Entrada de Gado" (1784-1789) fl. 144v.

65. AMS. "Livro de Partes e Ofícios da Administração da Feira." (1801-1810) 
Talvez parte da preocupação esteja vinculada a quantidade de conflitos que o período registrou quanto as divisões dos talhos entre os marchantes. Os principais lugares citados no documento eram Brotas, Mercês, Baixa [dos Sapateiros], Soledade, Porta de S. Bento, Carmo, Conceição da Praia, Preguiça, Terreiro, Forte do São Francisco, São Francisco de Paula, Cruz de Pascoal, Santa Barbara e Sant'Ana. Possivelmente os maiores açougues possuíam alguns divisões internas denominadas talhos. Os outros talhos espalhados pela cidade tinham uma estrutura menor e eram concedidos à marchantes que administravam este pontos menores de comércio da carne verde.

Segundo as posturas municipais, a venda de carnes nos talhos e açougues só poderia ser feita das 6 horas da manhã até o meio-dia (durante o verão) ou até às duas horas da tarde (durante o inverno) "sob pena de ser apreendida e lançada ao mar ou enterrada toda a que for achada depois disso ". Era comum o costume de jogar os restos de carne na praia ou enterrá-las na beira do mar caso estivesse estragada e não indicada para o consumo. Gilberto Freire versou em "Sobrados e Mocambos" sobre o hábito que exemplificava bem a relação dos homens dos século XVIII e XIX com a praia, mas principalmente o mar, entendido como um lugar dado ao descarte daquilo de que não precisavam. Não era costume evidentemente, os passeios pela orla e muito menos os banhos de mar. ${ }^{66} \mathrm{O}$ costume de incinerar a carne imprópria para alimentação ou fruto de reses doentes só foi adotado depois do generalizado costume da população mais pobre de desenterrar e consumir o produto descartado em momentos de carestia. ${ }^{67}$

O dia de comprar a carne verde nos açougues era tradicionalmente o domingo. Recém- cortada, estava ainda relativamente fresca, podendo ser vendida por $1 \$ 000$ a arroba. Nos outros dias da semana, o preço era menor. Com $\$ 800$ era possível comprar uma arroba de carne de menor qualidade, evidentemente. As melhores partes do boi eram as mais procuradas, sendo vendidas relativamente rápido para os primeiros clientes que conseguissem chegar aos açougues. Como foi denunciado mais de uma vez, os poderosos da cidade recorriam a sua influência para garantir que seus escravos e empregados passassem na frente e levassem para casa o melhor talho possível. ${ }^{68}$ As camadas médias da população tinham acesso somente a carne de segunda qualidade. Aos mais pobres restavam os miúdos e os rebotalhos.

O comércio e o consumo de carne deixou marcas indeléveis na composição espacial da cidade de Salvador, ficando por testemunho o nome de ruas, bairros e rios. Pernambués, por exemplo, é um conhecido bairro da periferia soteropolitana. Segundo a tradição oral, por ali existia uma passagem pela qual transitava as boiadas dos grandes fazendeiros, tornando então o lugar

66. Gilberto Freyre. Sobrados e Mucambos. Decadência do patriarchado rural no Brasil. São Paulo, 1936.

67. Idem.

68. AMS. Atas da Câmara (1684-1700)."Termo de vereação e resolução que tomaram os oficiais da Camara sobre se não vender nos currais quarto de carne a pessoa alguma de qualquer condição que seja excetuando somente comprador do senhor governador." vol. 6, 9 de junho de 1694, p. 247. 
conhecido com "Pés de boi" ou "Perna de boi". Especialistas consideram o termo como uma corruptela provinda de algum dialeto africano. ${ }^{69} \mathrm{~A}$ maior parte das praças públicas que se mantiveram enquanto tal permaneceram desocupadas de residências e pontos comerciais devido ao fato de serem mantidas pela municipalidade enquanto currais.

Nos séculos XVIII e XIX havia várias ruas em Salvador que faziam referência direta ao comércio de carne. Rua dos Marchantes, do Gado, dos Ossos, dos Currais Velhos são alguns dos exemplos arrolados. Muitas delas localizadas nas imediações do segundo matadouro público construído ao lado do Forte do Barbalho, próximo inclusive da fonte d'água do Queimado. ${ }^{70}$ Aliás, a existência de água próximo aos locais de abate de gado era indispensável para manter o mínimo de asseio num local tão propício à insalubridade. Citemos novamente a rio das Tripas.

Mesmo sendo fartamente lembrado enquanto alimento cotidianamente consumido pela totalidade da população colonial, devido aos altos preços da carne e as constantes flutuações de abastecimento, é possível que os habitantes mais pobres dos grandes centros raramente se alimentassem de carne de vaca. ${ }^{71} \mathrm{O}$ lombo do boi (hoje conhecido como filet mignon) era o pedaço mais nobre e caro, assim como as partes traseiras dos bovinos, sempre cobiçadas pelos moradores mais abastados da cidade precisando ter o preço tabelado para não serem negociados por valores excessivos. ${ }^{72}$ A camada média da população consumia carne de segunda e a parte dianteira dos bovinos. Os menos abastados recorriam aos miúdos e à carcaça, comercializada por negras ambulantes que se encarregavam de pegar os restos dos animais logo depois do abate. O preço dos miúdos também era regulamentado pela municipalidade. Principalmente nos momentos de carestia, editais afixados nos pontos mais movimentados da cidade publicavam os preços pelos quais as partes menos "nobres" dos bovinos deveriam ser vendidas. Na década de 1720, os preços foram estipulados da seguinte forma: Cabeça de boi ou vaca com língua $\$ 100$, só a língua $\$ 050,1$ libra de fígado $\$ 020,1$ libra de coração $\$ 020,1$ bofe inteiro $\$ 100,1$ rabada $\$ 030,2$ libras de tripas $\$ 020 . .^{73}$ Uma postura municipal versava sobre a proibição da venda de abortos ou terneiros e de carne de feto moqueadas ou assadas. Possivelmente na hora do abate, algumas vacas estavam prenhas e ficavam entre o material descartado, junto aos miúdos, a carne do aborto. Se havia uma proibição "por serem de ordinário corrompidas como mostra a experiência", significa que eram largamente consumidos por serem vendidos com um preço menor. ${ }^{74}$ Somente

69. Ver: Elisabete Santos, José Antonio Gomes de Pinho, Luiz Roberto Santos Moraes, Tânia Fischer (orgs.). O Caminho das Águas de Salvador. Salvador, 2010, p. 162.

${ }^{70}$. Rodrigo Lopes, op. cit. p. 54.

71. APEB. Maço 201-14. Correspondência recebida pelo governo. Senado da Camara da Bahia (17831799). 8 de fevereiro de 1797

72. AMS. Atas da Camara (1684-1700). vol. 6. 20 de agosto de 1696. p. 321.

73. AMS. Portarias da Camara (1710-1725) "Edital que se mandou botar pelas ruas sobre o preço das tripas e mais miudos dos currais", fl. 14.

74. AMS. Posturas Municipais (1829-1859). Título 3 artigo 66 Parágrafo 7,8,9,10 da lei de 1 de outubro de 1828 
dois lugares da cidade tinham autorização para comercializar os miúdos no início do século XVIII: a Praça desta cidade (abastecida com os miúdos vindos dos currais de São Bento) e a Praça do Terreiro de Jesus (abastecida com os miúdos provenientes dos currais do Carmo). ${ }^{75}$

Em todas as etapas da comercialização e do consumo da carne verde para o período setecentista ficou evidente a importância do calendário litúrgico como referência temporal para o ciclo da mercadoria gado. Nas "Constituições Primeiras do Arcebispado da Bahia" editadas em 1719 aparece a proibição, sob pena de excomunhão, do consumo de carne durante o período da Quaresma. Este costume sempre foi respeitado pela tradição cristã que aconselhava a manutenção do jejum ou no máximo a ingestão somente de carne de peixe durante a Semana Santa. No conjunto de regras que regiam a vida dos cristãos, transcritos nas "constituições" havia uma cláusula específica sobre a proibição de venda e corte de carne durante este período cuja punição podia recair sobre almotacéis ou qualquer oficial que consentisse no talho, corte ou venda realizada publicamente nos açougues, praça, ruas ou quitandas, exceto para os doentes. A proibição mencionava marchantes e carniceiros que não deveriam cortar ou vender carne tendo por exceção somente aquela destinada a atender aos enfermos. ${ }^{76}$ Os contratos de arrematação das rendas dos talhos eram firmados durante o período da Quaresma para que os açougues estivessem em plena condição de voltar a operar logo depois da Páscoa.77 A produção pecuarista era referida enquanto "safras" do mesmo modo como é costume utilizar o termo para descrever a produção agrícola anual. As safras de carne tinham por base o calendário litúrgico. O cálculo da produção anual e fechamento do ano fiscal ocorria tendo por referência também a Páscoa. Sendo assim, a "safra" de um determinado ano ia da semana após a Páscoa até o Entrudo (Carnaval) do ano seguinte. ${ }^{78}$ A contabilidade da feira de Capuame acompanhava esta mesma lógica, ficando documentada nos "Livros de Entrada de Gado" o período em que o comércio era suspenso e o registro era fechado para balanço.

Mas nem só de carne fresca, ou carne verde, fez-se a alimentação dos soteropolitanos no século XVIII. As posturas municipais, ou seja, os códigos estipulados para um bom abastecimento visando a satisfação do "bem comum", versavam sobre o comércio e a fixação de preço de vários gêneros alimentícios, comercializados nas mais distintas partes da cidade. Em armazéns, bancas, quitandas e nos tabuleiros das negras ganhadeiras e verdureiras, os alimentos podiam ser comprados em qualquer canto da movimentada capital. O comércio de farinha de mandioca, feijão seco ou

\footnotetext{
75. Avanete Pereira Sousa. op. cit. , p. 292.

76. Dom Sebastião Monteiro da Vide. Constituições Primeiras do Arcebispado da Babia. (Impressas em Lisboa no ano de 1719, e em Coimbra em 1720. São Paulo): Tip. 2 de Dezembro, 1853. p. 163

77. AMS. Atas da Camara (1700-1718) “Termo de vereação e requerimento que fez o procurador sobre a renda dos talhos". Vol. 7. 10 de março de 1703. p. 146 ; "Termo de vereação e resolução que se tomou sobre o acordão da relação desta cidade em que mandam sejam citados os criadores para ajuste do que há de pagar pela fabrica que se lhe dá para matança dos gados.” vol. 7. 22 de março de 1703. p. 149.

78. AMS. Atas da Camara (1700-1718). vol. 7. 15 de fevereiro de 1703. p. 139-140.
} 
verde, arroz, peixes, frutas (uva ferrias [sic], uva mascate branca, limão doce, limão azedo, laranja da terra, lima, carajás da terra, xina, manga, ananás, mangabas, belancia [sic], melão, jaca, fruta do conde, banana de São Tomé, romã), "cocos torniados de beber agua, coco de comer", pepinos, abóbora d'água grande, alface, cebola da terra foram registrados. ${ }^{79}$

A carne do peixe era muito mais acessível ao grosso da população que podia pescá-lo nos arrebaldes da movimentada Salvador. A queixa de Vilhena dos Santos quanto ao alto preço do peixe fresco na cidade da Bahia em fins do século XVIII, certamente foi observada pela perspectiva de um homem da elite que dificilmente sairia de seu sobrado para pescar nas ribeiras da cidade. A pescaria assim como os passeios pela orla da praia não eram opções de lazer para os desocupados dados ao ócio em pleno século XVIII. ${ }^{80}$ Para este caso, decerto o peixe fresco chegava para ser vendido por um preço exorbitante até passar pelas mãos de inúmeros intermediários. De fato havia uma quantidade significativa de comerciantes que monopolizavam algumas áreas de pesca, mas isso não impedia aos mais pobres que tivessem fácil acesso ao mar, aos instrumentos e executassem por conta própria a tarefa. Há poucos estudos sobre a pesca na Bahia, mas o levantamento feito por Rafael Portela, tendo por base a documentação produzida pela Capitania dos Portos criada em 1840, aponta para predominância de homens livres pobres dedicados à pescaria no vasto litoral baiano. ${ }^{81}$

Em uma sociedade onde nem tudo o que era consumido passava pela economia de mercado, era generalizada a existência de pequenas hortas e pomares, mesmo nas casas mais pobres. Árvores frutíferas certamente faziam parte da paisagem soteropolitana, dificilmente mapeáveis pelo historiador na medida em que os aspectos mais cotidianos da vida colonial escaparam aos olhos de muitos cronistas e burocratas. Possivelmente todos os moradores que pudessem contar com um terreiro razoável tinham a alternativa também de construir pequenos galinheiros ou chiqueiros, diminuindo sempre que possível a necessidade de comprar boa parte dos produtos e alimentos necessários para o sustento das famílias. Todavia, assim como lembra Fernand Braudel, é necessário ter em mente que os trabalhadores, mais do que os senhores, eram condenados a serem "prisioneiros" do abastecimento, na medida em que somente os mais abastados possuíam terras capazes de manter cultivos, nem que fossem em pequena proporção. ${ }^{82}$

Os ovos e o leite também faziam parte da dieta colonial. Livros de receita mostram a quantidade de derivados animais corriqueiramente consumidos pela população um pouco mais abastada. Um livro do início do século XVIII, escrito pelo português Francisco Borges Henriques, mostra diversas receitas provenientes de diferentes lugares do Velho e Novo Mundo.

\footnotetext{
79. AMS. "Livro de posturas municipais" (1829-1859). Reedição e referência às posturas municipais de 1626 e 1730 , fl. 31.

80. Gilberto Freyre. op. cit.

81. Rafael Davis Portela. Pescadores na Babia do século XIX. Salvador, 2012.

82. Fernad Braudel. Civilização Material, Economia e Capitalismo: séculos XVI-XVIII. São Paulo, 1996. Vol. 2 "O jogo das trocas", p. 41.
} 
Dentre as receitas culinárias provindas do Brasil, duas delas foram caracterizadas como genuinamente provindas da Bahia, dentre elas estava a ambrosia, feita com ovos e leite coalhado no banho-maria. Fora a limonada e o doce de laranja, as outras receitas "à moda brasileira" tinham como ingredientes ovos ou leite, tais como "Ovos moles excelentes do Brasil" e a "Papa de Arroz".83 Evidente que tudo dependia da posição social da consumidor, assim como do acesso que cada pessoa podia ter em relação aos variados produtos consumíveis. Os ovos e as galinhas podiam ser mais facilmente adquiridas por aqueles que morassem em fazendas e arrebaldes com espaço suficiente para a criação dos pequenos galináceos. ${ }^{84}$ É comum a referência largamente propagada de que as galinhas serviam de alimento preferencialmente aos enfermos e mulheres recém paridas. ${ }^{85} \mathrm{Na}$ festa feita por Antonio Gomes Ferrão Castelo Branco para comemorar o ritual de passagem de suas irmãs D. Damiana, D. Justa e D. Rufina professas do Convento das Mercês no dia 12 de fevereiro de 1757, o senhor de engenho pagou a D. José de Miralles $22 \$ 800$ por setenta galinhas, ovos e o carreto necessário. ${ }^{86} \mathrm{~A}$ mesma relativa facilidade de acesso deveria ocorrer com o leite. Aqueles que dispusessem de uma vaca leiteira podiam contar esporadicamente com o leite produzido nos períodos de alimentação dos bezerros.

Aos ricos e possuidores de razoável cabedal, o acesso aos alimentos se dava também através da compra. Todavia, não nos esqueçamos que a riqueza na colônia relacionava-se diretamente ao controle sobre a terra e sobre o trabalho escravo. Isso significa que as famílias mais ricas possuíam na maioria das vezes propriedades rurais ou pelos menos grandes terrenos em que conseguiam colocar seus escravos para produzir alguns gêneros, nem que fosse em pequena escala. A mãe do senhor de engenho Antonio Gomes Ferrão Castelo Branco, por exemplo, possuía uma roça no Papucu. Passava semanas e semanas, cuidando das plantas, das roseiras e criando as galinhas. ${ }^{87}$ Isso certamente tornava as famílias mais abastadas as menos vulneráveis em

83. Isabel Drumond Braga. "Influências estrangeiras nos livros de cozinha portugueses (século XVIXIX): alguns problemas de análise", Estudos em Homenagem ao Prof. Doutor José Marques, vol. 2, Porto, 2006, p. 237-247.

84. No momento de formulação da Junta das Missões, Antônio Gomes Ferrão Castelo Branco foi informado de que as aldeias estabelecidas no sertão do Porto da Folha (de que era herdeiro) precisavam obedecer a novos padrões. Dentre eles, dar terra suficiente para que pudessem “ criar comodamente as suas galinhas e ter as suas éguas ou cavalos, sem os quais nenhum poderá viver no Sertão". Antonio Gomes Ferrão Castelo Branco. Borrador em que lanço todas as cartas que escrevo, principiado em agosto de 1742, estando na Babia (século XVIII). São Paulo, Coleção José Mindlin [transcrito por Rosana Gonçalves e gentilmente cedido por Prof. Dr. Istvan Jancsó],fl. 117.

85. Quando as irmãs do senhor de engenho Antonio Gomes Ferrão Castelo Branco estavam enternadas no convento das Mercês e ficaram doente, o provedor da família enviou galinhas e dinheiro para a manutenção das enfermas em 1752. fl. 44, 58. O vaqueiro Antonio Pereira do capitão João do Rego Castelbranco, responsável por levar uma boiada do Porto da Folha até feira de Capuame em junho de 1756, consumiu 3 galinhas durante a estadia em Papucu, por estar doente .fl. 123. Antonio Gomes Ferrão Castelo Branco. Borrador ... Ver também : Laura de Mello e Souza. "Formas provisórias de existência: a vida cotidiana nos caminhos, nas fronteiras e nas fortificações." Fernando Antonio Novais (org.) História da vida privada no Brasil. Vol. 1: Cotidiano e vida privada na América Portuguesa. São Paulo, 1997. p. 48

86. Antonio Gomes Ferrão Castelo Branco. Borrador ..., fl. 154v.

87. Idem, fl. $77 \mathrm{v}$. 
momentos de carestia, visto poderem recorrer tanto à produção interna de suas propriedades quanto às mercadorias comercializadas largamente nas ruas da cidade. ${ }^{88}$ Agora, mesmo que admitamos que nem todos os alimentos ingeridos no período colonial passassem obrigatoriamente pela esfera da economia de mercado, não tinha jeito: no caso do consumo da carne verde em uma cidade como Salvador fazia-se necessário (na maior parte dos casos) comprá-la no açougue ou em postos clandestinos.

\subsection{Agentes mercantis: arrematadores, marchantes e contrabandistas}

Era comum aos Estados Modernos governados pela lógica de Antigo Regime delegarem o controle sobre o abastecimento alimentar dos florescentes centros urbanos espalhados pelo território europeu à municipalidade. Este costume foi trasladado para as colônias estabelecidas no Novo Mundo rapidamente pontilhadas por cidades portuárias, tais como Salvador, que tomaram vulto nos séculos XVII e XVIII devido a constante movimentação de homens, mercadorias e homens-mercadoria. No caso da primeira capital da América Portuguesa, a administração do abastecimento era realizado pela Câmara Municipal de Salvador. ${ }^{89}$ Assim como a farinha de mandioca, a carne verde era um dos alimentos considerados imprescindíveis para a dieta da população da Bahia. ${ }^{00}$ Se por um lado os produtos agrícolas tais como a farinha de mandioca tiveram o relativo controle garantido finalmente com a construção de um Celeiro Público em $1785^{91}$, no caso da carne verde o controle se dava desde ao menos a metade do século XVII através de várias diretrizes executadas em parte pelo trabalho direto de funcionários nomeados pelo município, em parte por particulares arrematantes do direito de encaminhar as reses e distribuir a carne pelos açougues.

Desde a supervisão sobre as boiadas que chegavam em feira de Capuame, até o encaminhamento dos bovinos para o abate no matadouro e a distribuição da carne pelos açougues soteropolitanos: todas as etapas eram acompanhadas direta ou indiretamente por funcionários ligados à Câmara Municipal. Interessante notar que a administração da feira de Capuame era efetivada por um funcionário municipal: o superintendente, auxiliado pelo escrivão e tesoureiro. Esta não era a regra. Como ficou evidenciado por Helen Osório, para o caso dos registros de Viamão e Curitiba, prevalecia a gerência

\footnotetext{
88. Sobre o comércio de alimentos na cidade de Salvador, ver: Richar Graham. op. cit.

89. Avanete Pereira Sousa. op. cit.

90. Richard Graham. op. cit.

91. No caso da farinha de mandioca, o município possuía um controle sobre a produção e comércio desde o século XVII, ordenando a obrigatoriedade de plantio de uma quantidade determinada de covas aos grandes comerciantes, senhores de engenho e fazendeiros, faziam as vilas de Cairu, Camamu e Boipeba contribuirem com o abastecimento de Salvador, mas não havia nenhum contrato ou controle semelhante ao comércio da carne. Para um estudo pioneiro sobre o Celeiro Público de Salvador, ver. Avanete Pereira Sousa. "Poder local, crises de subsistência e autonomia camarária (Salvador, século XVIII)”, XXVI Simpósio Nacional de História, São Paulo, 2011.
} 
incumbida ao contratador que precisava somente prestar contas no momento em que firmava o contrato e pagava um valor fixo pelo direito comprado. ${ }^{92}$

Os olhos atentos dos funcionários municipais em relação ao comércio do gado não eram à toa: a maior fonte de renda da Casa da Câmara provinha do comércio dos talhos, através dos valores fixos estipulados anualmente pelos contratos de arrematação. Segundo Avanete Sousa, a renda dos talhos correspondia a $71,89 \%$ do total arrecadado pela Câmara de Salvador entre os anos de 1701-1725 e 1739-1767. Havia mais três fontes de renda do município: a Balança da Praia, respondendo por 16,57\%; a Renda do Ver com $11,11 \%$ e por último a Balança do Pescado, representando $0,44 \%$ do total coletado no período levantado pela historiadora. ${ }^{93}$ Entre os anos de $1768 \mathrm{e}$ 1800 a importância da renda dos talhos para as finanças do município aumentou: passou a representar $85,86 \%$ do valor total arrecadado, seguido pela renda da Balança do Peso Real (7,54\%), Renda do ver (6,31\%), Balança do Pescado $(0,30 \%) .{ }^{94}$

As rendas relacionadas as balanças estavam vinculadas ao costume da Câmara Municipal de verificar e aferir os instrumentos utilizados para medir os produtos comercializados. Havia três balanças públicas na cidade: a Balança da Praia, do Pescado e do Peso Real (usada para pesar as caixas de açúcar e tabaco). A Câmara cobrava uma determinada taxa pela utilização do instrumento localizado na freguesia de Conceição da Praia, um dos termos mais movimentados e de intenso comércio. ${ }^{95}$ A Renda do Ver condizia com a necessidade da Câmara em terceirizar o trabalho de fiscalizar e cobrar dos distintos comerciantes o cumprimento das normas estipuladas pelas Posturas Municipais. ${ }^{96}$

Como demonstra a arrecadação e as rendas da Casa da Câmara, nem sempre o controle municipal era feito de forma direta: mostrou-se um hábito do período estudado a concessão de direito de comércio à particulares que ficavam encarregados de cumprir o papel facultado ao município. A formalização desta concessão sobre o controle do abastecimento de carne, por exemplo, dava-se através do contrato de arrematação das rendas dos talhos. $\mathrm{O}$ arrematador deste contrato tinha o dever de manter os açougues sempre abastecidos de carne verde, preservar fisicamente pelo bom funcionamento dos prédios públicos vinculados ao comércio do gênero, assim como contratar e pagar os escravos e outros funcionários necessários para as atividades vinculadas ao corte e carregamento da mercadoria. Nos açougues haviam alguns funcionários nomeados pela própria municipalidade que não

\footnotetext{
92. Helen Osório. "As elites economicas e a arrematação dos contratos reais: o exemplo do Rio Grande do Sul ( século XVIII)". João Fragoso, Maria Fernanda Bicalho, Maria de Fátima Gouvea(org.). O Antigo Regime nos Trópicos. Rio de Janeiro, 2001, p. 107-137.

93. Avanente Pereira Sousa. Poder local, cidade e atividades econômicas (Babia, século XVIII). USP, São Paulo, 2003 , p. 228.

94. Idem, p. 230.

95. Idem, p. 215 e segs.

96. Idem.
} 
respondiam diretamente ao arrematante do contrato dos talhos, tais como o cobrador, o porteiro e os soldados que faziam a ronda.

Assim como mencionado anteriormente, o contrato de arrematação da renda dos talhos eram colocados em hasta pública durante o período da Quaresma. Ficava em pregão por trinta dias, recebendo os lances, até que chegasse o momento da apuração. No dia da confirmação e fechamento do contrato, reuniam-se na praça pública em frente à Câmara todos os interessados e envolvidos. O porteiro anunciava o nome do arrematador que havia dado o maior lance, vencendo a concorrência. O novo responsável pela renda dos talhos, erguia um ramo de folhas verdes e batia-se o martelo.

O valor do contrato era uma quantidade fixa de dinheiro que o arrematador deveria entregar aos funcionários da Câmara em moeda corrente de contado. O preço da carne a ser comercializada nos açougues era estipulada pela municipalidade e deveria ser respeitado sob risco de punição. O lucro do arrematante era portanto a diferença entre o valor do contrato, os gastos com funcionários e a manutenção dos espaços de comércio em relação ao total arrecadado pela venda da carne. Difícil fazer uma cálculo preciso sobre qual era o lucro dos contratadores, mas tudo leva a crer que este era um ótimo negócio atraindo grandes comerciantes que atuavam em grupos de sócios, além dos fiadores, em geral, destacados homens de negócio.

Já que o valor do contrato devia ser pago em dinheiro no final do período, fazia-se necessário a apresentação de um fiador para os casos em que o arrematante não conseguisse quitar as dívidas com o município. No ano de 1681 os funcionários da Câmara executaram a dívida contraída pelo arrematador João Delgado. Visto não conseguir "honrar" com suas contas e por ser despossuído de bens que pudessem ser confiscados, quem pagou pelo negócio foi o fiador, o Alferes Antão Alvares Barreto. Sua fazenda foi tomada e leiloada pelo valor de $200 \$ 000$ ao capitão Gonçalo Ravasco Cavalcanti de Albuquerque. ${ }^{97}$

Sabendo que os açougues eram divididos internamente em talhos, era o arrematador o responsável por repassar cada um dos talhos aos cuidados de uma outra pessoa interessada em trabalhar com este negócio tão lucrativo. Muitos deles eram marchantes, já envolvidos com a negociação do gado desde a feira de Capuame. Segundo os contratos de arrematação das rendas dos talhos da década de 1760, somente os marchantes podiam enviar lances e concorrer à licitação. Ao que tudo indica também eram os responsáveis por cada um dos talhos distribuídos pelo arrematador. Certamente esta norma não prevaleceu por todo o período de vigência dos contratos controlados pela municipalidade, visto as constantes alterações que o comércio de gado sofreu durante o século e meio analisado nesta dissertação, mas é possível que houvesse uma preferência pela atuação de homens necessariamente licenciados. De modo retrospectivo, pode-se notar que o contrato de

97. AMS. "Termo de uma petição que fez o Capitão Gonçalo Ravasco Cavalcanti de Albuquerque como arrematador da fazenda de Antão Alvares Barreto fiador que foi de João Delgado.” 22 de dezembro de 1681. p. 315. Atas da Câmara (1669-1684), vol. 5. 
arrematação das rendas dos talhos do ano de 1653 foi firmado com Noitel Rodriguez Domigos da Costa, Estevão Faleiro, Domingos Fernades, Francisco Vergella. Segundo o termo de vereação, os três homens eram marchantes. ${ }^{98}$ Infelizmente nem todos os contratos ou documentos restantes possuíam esta especificação, mas excetuando os anos em que os marchantes foram retirados totalmente do comércio de gado como represália dos vereadores diante dos disparates cometidos pela categoria, possivelmente a regra foi o envolvimento direto dos marchantes nos contratos de arrematação e na administração dos talhos.

$\mathrm{Na}$ década de 1670, os arrematadores da renda dos talhos queriam acrescentar como condição de seus contratos o privilégio de tornarem-se isentos de qualquer tipo de cobrança de finta. O pedido foi encaminhado ao provedor-mor que logo deferiu a solicitação. Evidente que a medida não agradou aos vereadores e senadores de Salvador que procuraram recorrer de imediato à decisão através de uma representação perante o Tribunal da Relação. ${ }^{99}$

Certamente os contratadores funcionavam como um grupo de pressão. Trabalhando em conluio e garantindo alguns acordos dentro de uma perspectiva corporativista, conseguiam controlar de modo indireto o preço da carne vendida na cidade. Helen Osório chega a verificar a formação de verdadeiros oligopólios de contratadores para o caso do Rio Grande do Sul. ${ }^{100}$ A situação parece ser bem semelhante para o caso de Salvador, apesar da necessidade de um estudo sistemático dos contratos e um levantamento detalhado da vida dos arrematadores para aprofundarmos a hipótese. Tanto era assim que no ano de 1656 os arrematadores fizeram os funcionários municipais passar temporariamente por maus momentos. Com o Entrudo e o início da Quaresma daquele ano, veio o final do contrato de arrematação das rendas do talho. A municipalidade se preparava para o momento de reabertura dos açougues após o período de resguardo espiritual. $\mathrm{Na}$ dia primeiro de março, depois do porteiro colocar em pregão o novo contrato, as autoridades foram surpreendidas pela falta de lances. Mandaram chamar imediatamente os marchantes para saber o que havia acontecido. Os negociantes de gado afirmaram que não aceitariam arrematar o contrato caso fossem mantidas as mesmas cláusula do ano anterior, a saber: cortar a carne por meia pataca, pagar aos criadores um tostão e mais treze vinténs por cabeça de gado que cabia à terça de Sua Majestade. A recusa em aceitar o acordo baseava-se no argumento de que o valor de meia pataca que cabia aos arrematadores não cobria os gastos que tinham em manter os açougues funcionando.

\footnotetext{
98. AMS. Atas da Camara (1649-1659), vol. 3 , 11 de março de 1653.“Termo de Contrato que se fez com os marchantes Noitel Rodriguez Domigos da Costa, Estevão Faleiro, Domingos Fernades, Francisco Vergella sobre se obrigarem a dar carne ao povo.” p. 237

99. AMS.Cartas Do Senado (1638-1673), volume 1, p. 95-96.

100. Helen Osório. "As elites economicas e a arrematação dos contratos reais: o exemplo do Rio Grande do Sul ( século XVIII)". João Fragoso, Maria Fernanda Bicalho, Maria de Fátima Gouvea(org.). O Antigo Regime nos Trópicos. Rio de Janeiro, 2001, p. 107-137.
} 
Os funcionários da Câmara de Salvador não insistiram no acordo e muito menos aceitaram renegociar os valores impostos pela municipalidade. Optaram por dar acesso livre aos criadores que cortariam por conta própria o gado que trouxessem dos sertões baianos. Podiam cortar a carne utilizando escravos seus ou de outrem. O município se comprometia a pôr uma balança nos açougues. Os criadores deveriam pagar um tostão por cada cabeça de gado. Tudo isso anotado pelo escrivão da Câmara e rubricado pelo Juiz Ordinário. Mas na última hora, apareceu um licenciado ${ }^{101}$ denominado Nicolau Alvares Figueira que aceitou prontamente assumir e arrematar o contrato das rendas dos talhos mantendo as mesmas cláusulas dos anos anteriores, seguindo o ofício já exercido pelo seu pai, Simão Alvares Figueira. Infelizmente não há indicação se os membros da família de arrematantes eram marchantes. ${ }^{102}$

Nos anos seguintes os desacordos entre os marchantes e os funcionários da Câmara Municipal de Salvador continuaram e os representantes da res publica e do bem comum mantiveram-se firmes na decisão de afastar os marchantes dos negócios envolvendo as arrematações dos contratos dos talhos. Várias foram as medidas tomadas no sentido de pensar nas novas diretrizes para o comércio. A regra era firmar acordo direto com o criadores que deviam trazer por conta própria os animais. ${ }^{103} \mathrm{~A}$ cada ano havia uma novidade na lógica do comércio. As mudanças demonstravam as tentativas, nem sempre felizes, dos funcionários municipais em manterem o mínimo de controle sobre o abastecimento sem a ajuda dos intermediários históricos: os marchantes. No período precedente à Páscoa de 1694, “ para se livrarem das confusões e malícias das petições", os vereadores decidiram que todos os criadores - publicamente conhecidos - que quisessem adquirir licença para cortar por conta própria o seu rebanho e "pedir talho" deveriam fazer a solicitação por escrito contendo o valor pelo qual queriam cortar a carne e colocar o papel em uma caixa depositada na Casa da Câmara. Depois de lidas todas as propostas, o procurador do Senado faria uma lista de classificação com valor crescente do preço anotado na solicitação. Em primeiro lugar estaria a solicitação com menor valor para cortar a carne e assim sucessivamente até o preço mais alto. Esta mesma ordem seria supervisionada pelo almotacel na hora da carne ser cortada e levada para o açougue. Resumindo: dependendo do criador, a carne teria um preço diferente. Os primeiros talhos comercializados eram mais baratos que os últimos, ou seja, quem chegasse primeiro no açougue compraria por um preço menor daquele que fosse fazer suas compras antes do estabelecimento fechar. Detalhe: o

101. O termo licenciado aparece como qualificativo do novo arrematante, mas não há especificação se era marchante ou não.

102. AMS. Atas da Camara (1649-1659), vol. 3, "Termo da resolução que se tomou sobre os açougues." p. 314.

103. AMS. "Termo de postura e requerimento que fez o capitão Domingos martins Pereira com o procurador de todos os criadores de gado destas capitanias aos oficiais da Camara estando em mesa de vereação.”20 de março de 1683, p. 347. Atas da Camara (1669-1684), vol. 5. "Termo de vereação e determinação que se tomou sobre uma petição de João Alvres Fontes João Antunes Moreira e Francisco Jorge como criadores de gado.” 31 de janeiro de 1686, p. 44. Atas da Camara (1684-1700) vol 6. 
sorteio seria feito semanalmente. Desnecessário dizer que o novo método só aumentou ainda mais a confusão na hora de controlar o abastecimento de carne à população. ${ }^{104}$

$\mathrm{Na}$ Quaresma do ano seguinte os contratos das rendas dos talhos estavam novamente colocados em pregão. Devido as confusões e os desacertos do período anterior, causando prejuízos para todas as partes, o contrato foi rapidamente arrematado por um valor muito mais alto do que os anos anteriores. Certamente os marchantes que permaneceram por mais de um ano distantes do lucrativo negócio das carnes, voltaram rapidamente para garantir a sua participação nos lucros. Todavia, pela acirrada concorrência e por algum motivo interno que não foi possível apreender com a utilização de uma única fonte coeva, o contrato que deveria ser firmado por 2:100\$000, de acordo com o maior lance feito pelo contratador Domingos d' Oliveira Lopes, acabou sendo arrematado de maneira obscura por Domingos de Magalhães, parente do vereador capitão Antonio de Magalhães. ${ }^{105}$

Seis anos depois o mesmo marchante, Domingos d' Oliveira Lopes, foi novamente posto fora da concorrência da renda dos talhos. Desta vez a explicação para a decisão do Senado foi outra: Domingos foi considerado um "homem revoltoso" pois prejudicava corriqueiramente o povo maquinando modos de enriquecer em detrimento do bem comum. Causava a diminuição das rendas do Conselho Municipal e da terça de Sua Majestade. Atuava mancomunado com mais quatro marchantes, juntando todos eles para comprar os comboios de gado sertanejo pelo menor preço possível. Já tinha sido autuado várias vezes. Os vereadores pediram intercessão do rei para que o arrematador não fosse mais admitido nas negociações de gado nem no caso em que provasse estar comercializando o seu próprio rebanho trazido de suas fazendas sertanejas. ${ }^{106}$ Conseguiram tirar o marchante do jogo das trocas com o consentimento do rei, em 1703. Na provisão despachada de Lisboa, o arrematador Domingos de Oliveira Lopes ficava terminantemente proibido de vender carne nos currais, até mesmo pelo intermédio de seus feitores e escravos. ${ }^{107}$ Interessante notar que não havia nenhuma acusação concreta em relação ao marchante. Fora o fato de se juntar com outros negociantes para comprar as reses por menor preço, visto certamente conseguir negociar um menor valor por requerer uma grande quantidade, não há mais nenhum indício que o culpabilizasse. Foi apontado como sendo o "cabeça e motor" do conluio. Não foi acusado de ser atravessador, mas certamente como um comerciante e bom conhecer dos melhores métodos de obtenção de lucros, não tinha o menor escrúpulo quando o assunto era manter sua alta rentabilidade. Talvez controlasse a oferta de gado para manter os preços

104. AMS. Atas da Câmara (1684-1700). vol. 6. 10 de abril de 1694. p. 242.

105. AMS. Atas da Câmara (1684-1700). vol. 6 ."Termo de resolução que tomarão os oficiais da Câmara sobre se não arrematar os talhos até se examinar se queria Domingos de Magalhaes dar maior quantia que e porque estava arrematado no livro de arrematações fl. 82." 20 de março de 1695. p. 278. 106. AMS. Atas da Câmara (1700-1718) .vol. 7. "Termo de vereação e resolução que se tomou sobre o não ser Domingos de Oliveira Lopes admitido a lançar nas rendas dos currais e talhos assim nesta Cidade como nas do termo." 14 de março de 1701, p. 54.

107. AMS. Atas da Camara (1700-1718) .vol. 7. “Termo de vereação”31 de março de 1703, p. 154. 
sempre altos. Talvez tudo isso fosse uma represália alimentada pela desavença pessoal com o parente do vereador capitão Antonio de Magalhães, também interessado nos contratos. Esta é uma hipótese. Bem factível, pensando em um arrematador cujo crime era ser um entendedor das artimanhas necessárias para sobreviver dentro de uma economia de mercado.

Em ata do dia 27 de março de 1751 os vereadores intimaram o arrematador do novo contrato firmado após a Quaresma a cumprir com uma das cláusulas impostas. Era obrigado a dar toda a carne necessária a sustentação dos enfermos e pobres sob o risco de pagar à Câmara uma multa de seis mil réis. Infelizmente o documento não especifica como funcionava este tipo de acordo firmado talvez há pouco tempo em caráter emergencial. Segundo os funcionários, "tem padecido o povo grande necessidade e falta dela [da carne] de sorte que são excessivos os clamores do povo". Todavia não havia nenhum tipo de indício do modo com a carne seria distribuída entre os enfermos e pobres. ${ }^{108}$ Talvez fosse através de alguma instituição? Difícil saber.

Na década de 1750 Thomas Veloso Rebello demonstrou interesse em se envolver diretamente com a fabricação de cortume na colônia. Recorreu diretamente ao rei e seus conselheiros para conseguir dar inícios aos seus negócios. Para facilitar a empreitada, Thomas Veloso Rebello solicitou sabiamente ter preferência na arrematação da renda dos talhos para assim garantir acesso direto ao couro retirado no momento de abate dos bois direcionados ao abastecimento de Salvador. Os funcionários da Câmara Municipal evidentemente não demonstraram nenhuma simpatia pela nova interferência. Não sendo cumprida prontamente a ordem emitida a pedido do rei, chegou uma nova portaria mandando-os acatarem e porem em prática imediatamente a solicitação. ${ }^{109}$

Os marchantes eram os negociantes de gado responsáveis por encaminhar as boiadas da feira de Capuame até a cidade de Salvador. Considerado inicialmente um ofício mecânico como qualquer outro (pedreiro, carpinteiro, marceneiro), para atuar na marchantaria, o interessado precisava desde o século XVII de licença municipal que o habilitasse a exercer a profissão .110 A permissão sempre era entregue a um pequeno grupo de homens. Não se sabe quais eram os critérios para a concessão da licença. Assim como os demais oficiais mecânicos, eles tinham as suas obrigações para com a municipalidade. Nos dias de procissão, por exemplo, possuíam um lugar assegurado ao lado dos carpinteiro, torneiro, marceneiro, entalhadores, tendo por obrigação no ano de 1699 de contribuir com "três tourinhos" para

\footnotetext{
108. AMS. Atas da Câmara (1751-1765). vol. 10. “Ata de 27 de março de 1751.”. p. 19.

109. AMS. Atas da Câmara (1751-1765). vol. 10. "Ata de 14 de abril de 1753.” p. 60.

110. Na Ata da Câmara de 15 de outubro de 1642 apareceram como marchantes licenciados Simão Alvares e Domingos da Costa. AMS. Atas da Câmara (1641-1647), vol.2, "Assento e rol das pessoas que foram chamadas para fazerem lançamento das vintenas que se lançam pelos oficiais nesta Cidade aos quais se deu juramento na forma do assento atras escritos."p. 132. Ver também: Maria Helena Flexor. Oficiais Mecânicos na cidade do Salvador. Salvador, 1974, p.12.
} 
ornamentar o evento religioso. ${ }^{111}$ Ao que tudo indica, no início não se tratava de uma atividade profissional muito glamourosa, resumindo-se muito mais a condução e compra das boiadas e entrega nos açougues.

Com o passar dos anos, com o aumento da população, o crescente comércio e elevação substancial de importância das negociações com gado para as rendas da Câmara, certamente a atividade de marchantaria passou a ter uma nova importância social. Já em 1699 é possível notar que dentre os oficiais mecânicos - enquanto cada categoria era representada por um único homem durante as procissões juninas - os marchantes eram os únicos que contavam com o privilégio de cada um se auto representar, mostrando assim a distinção com relação aos demais licenciados. ${ }^{112}$ Enquanto atividade mercantil, é curioso reparar que a mudança de status do marchante acompanhou uma tendência geral de mutação no papel social dos mercadores como ápice do capitalismo mercantil na colônia no século XVIII.

A possibilidade de enriquecimento na segunda metade do século XVIII atraiu maiores cabedais para a atividade. Não é a toa que a partir dos contratos de 1760 somente os marchantes podiam arrematar o contratos das rendas dos talhos. Sendo homens versados nos negócios de gado, com importância estratégica nas finanças do município, o grupo possuía influências nas decisões da Câmara e possivelmente tiveram alguma participação na nova medida. Certamente agiram como categoria imbuída de interesses em comum para garantir diante da municipalidade que somente os marchantes licenciados pudessem participar do lucrativo comércio do gado em pé.

Vários marchantes possuíam outros negócios e atividades mercantis, alguns tinham fazendas de gado espalhadas pelos sertões baianos e até mesmo unidades produtivas na região da Feira de Capuame. Antonio Lopes, marchante que atuou na feira de Capuame durante a década de 1780, apareceu nos documentos também como possuidor de uma fazenda na região da freguesia da Mata de São João, próximo a feira, em que às vezes deixava gado à solta. João do Rego Gomes era outro marchante atuante na década de $1780 \mathrm{e}$ simultaneamente apareceu como dono da fazenda do Trapixe, próximo ao local da feira. Constantino Alves da Cruz era marchante e ao mesmo tempo administrava as fazendas Capuame e Bandeira pertencentes a João Francisco da Costa. ${ }^{113}$

Manoel Felix da Veiga era ao mesmo tempo marchante, comerciante e fazendeiro. Seu inventário foi aberto em 1797, mas o seu nome aparece nos registros mesmo depois desta data. A questão é que seu filho mais velho possuía o mesmo nome e pelo o que tudo indica, o rapaz deu continuidade as

111. AMS. Atas da Camara (1684-1700). vol. 6. "Termo de resolução acento e obrigação que fizeram os juizes dos ofícios e mais pessoas nomeadas a quem encarregou as ensignias e mais obrigações que tocam a cada um dos ofícios." 4 de junho de 1699. p. 374;

112. Idem.

113. APEB. Senado da Camara de Salvador. Correspondência expedida ao governo (1789). Maço 4851. 30 de junho de 1789, fl. 25 . 
atividades comerciais do pai114. Manoel Felix da Veiga (o pai) era marchante e além de ser "estabelecido em mercancia, tinha muitas correspondências para o Recôncavo e sertões desta Bahia e Capitania, assistindo muitos engenhos."115 Antes de seu pai falecer, Manoel (o filho) já era caixeiro e guarda-livros da casa comercial em que seu pai era negociante de fazendas sortidas. Um dos grandes problemas colocados neste extenso inventário é o fato do filho ter espoliado a parte que cabia a sua mãe e ao seu irmão ainda menor de idade.

O que importa aqui é pensar principalmente na figura do pai, como um negociador que percorreu o sertão, possuía contato e negócios em outras atividades além da marchantaria. Era um dos irmãos da Santa Casa de Misericórdia e entre seus bens encontravam-se prata e objetos de luxo comercializados em sua loja. Possuía também uma fazenda de gado denominada Boqueirãozinho, localizada no Sertão de Sento Sé, com uma quantidade grande de gado ${ }^{116}$.

Mas nem todos os marchantes tiveram um final de vida próspero. Infelizmente foram poucos os inventários encontrados que tivessem como uma das partes os homens envolvidos diretamente no comércio do gado em pé. João de Deus Salvador, por exemplo, faleceu em 1822 quando já tinha mais de 80 anos. Era natural da cidade de Salvador, atuava como marchante ainda na década de $1780^{117}$ e segundo menciona o inventário, morreu muito pobre e debilitado, sendo foreiro de duas braças de terra na "Rua chamada dos Ossos", apesar de já ter sido dono de uma casa na Rua dos Perdões cito na freguesia de Santo Antonio Além do Carmo, comprada em 1780 de Joaquim da Silva por $200 \$ 000$ (com escritura lavrada no cartório de Manoel Antonio Campelo) e outra casa na Rua dos Ossos em Santo Antonio Além do Carmo que comprou de Josefa Maria da Conceição em 9 de setembro de 1790 por $55 \$ 000 .{ }^{118}$ Em 1794, João de Deus Salvador firmou um contrato matrimonial com Vicência Maria da Conceição no qual fazia questão de especificar a união com total partilha de bens. Este procedimento era comum quando os cônjuges possuíam padrões de vida muitos distintos. Talvez não tivesse interesse em compartilhar os bens adquiridos com a nova esposa, por trazê-la em desconfiança. No momento da união possuía uma vida um pouco mais abastada. Tinha as duas casas próprias acima citadas e certamente ainda atuava como marchante. Possuía "duas bestas de carga com seus aparelhos de carregar carne dos açougues dos currais para os açougues" avaliados em $100 \$ 000$, um cavalo de carga avaliado em $30 \$ 000$ e mais dois cavalos com sela avaliados cada um em $40 \$ 000$, fivelas de prata, espada de ferro, alguns móveis, artigos de prata e ouro, além dos escravos Pedro (crioulo) e Maria

\footnotetext{
114. Aliás, um dos grandes problemas na localização das fontes é saber se estamos diante da mesma pessoa que figura em mais de um documento. Vários são os impasses: primeiros quanto aos homônimos e depois quanto a falta de critérios mais rígidos os escritores dos documentos na hora de escrever os nomes. Nem todos os sobrenomes eram mencionados. Este é sem dúvida um dos momentos mais delicados da pesquisa na hora de cruzarmos informações de origens distintas.

115. APEB, Seção Judiciária, Inventário de Manoel Felix da Veiga e.4, cx. 1578, m. 2047. fl. 74, 1797.

116. Idem, fl. $112 \mathrm{v}$.

117. AMS. "Livro de Registro de Entrada de Gado" da feira de Capuame. (1784-1789)

118. APEB, Seção Judiciária, Inventário João de Deus Salvador, e.4, cx. 1750, m. 2220, d. 3., 1822.
} 
(mulata). ${ }^{119}$ João de Deus Salvador, por mais que não pareça de fato ter adquirido bens consideráveis com o ofício, encontrava-se em plena decadência, talvez por outros fatores também, mas principalmente por sua idade e provável impossibilidade de trabalhar. Em seu inventário não foi arrolado nenhum filho, somente o marido da sua enteada (filha da mulher com que João Salvador de Deus foi casado).

Nos anos de 1784-1789, de acordo com os "Livros de registro de entrada de gado" da feira de Capuame é possível ver a referência a quarenta marchantes vinculados diretamente ao comércio. Nem todos atuaram simultaneamente em Capuame, sendo comum que conseguissem licença para atuar somente por alguns anos, migrando para outras atividades mercantis. Mas alguns deles apareceram em todos os anos analisados através da documentação. ${ }^{120}$

Assim como todos os comerciantes de uma sociedade de Antigo Regime, apesar da influência social que conseguiam barganhar graças ao cabedal acumulado pelo retorno financeiro comum à profissão, os mercadores, contratadores e marchantes sempre foram alvo de desconfiança por parte de seus contemporâneos. Esta imagem tendia a ser alterada com o tempo, todavia é corriqueira a contraposição que os funcionários da Câmara Municipal faziam entre os espertos e trambiqueiros marchantes e os trapaceados criadores sertanejos.

Sabendo do grande volume de gado que havia estacionada na região de Capuame no mês de outubro do ano de 1695, os marchantes decidiram conjuntamente não levar nenhuma rés para abastecer a cidade de Salvador para não ocorrer uma baixa do preço pago pela carne. Por "ser conhecido o dolo, malícia e simulação com que os ditos marchantes se haviam conluiado", os vereadores optaram por mandar alguns militares fazerem uma busca nos pastos em que os marchantes costumavam deixar o gado. ${ }^{121}$ Tinham autorização para trazer a força todas as reses que estivessem na região próxima a Capuame ${ }^{122}$, visto a falta ter sido causada por motivos artificiais para que houvesse uma elevação compulsória dos preços do mantimento.

Era comum os marchantes agirem articuladamente também no momento de arrematação das rendas dos talhos. O pregão feito no ano de 1696 teve as cláusulas contratuais alteradas porque os vereadores desconfiaram por "presunções e conjunturas evidentes" ter ocorrido um acordo entre Gaspar Ferreira de Carvalho e seus companheiros de ofício. Ao que tudo indica, ficou combinado que mais nenhum negociante concorresse ao lance para que o valor do contrato fosse rebaixado. De fato, no ano anterior a arrematação foi feita por quase dois contos de réis após um período de ausência de concessões

119. Idem.

120. AMS. "Livro de Registro de Entrada de Gado" da feira de Capuame. (1784-1789)

121. AMS. Atas da Camara (1684-1700), vol. 6. "Termo de vereação e requerimento que fez o juiz do povo sobre se dar meio para se conduzir os gados que houver nos pastoradoros pertencentes aos marchantes." 26 de outubro de 1695.

122. AMS. Atas da Camara (1684-1700), vol. 6. 22 de setembro de 1696, p. 324. 
por ordem da Câmara Municipal. Para que houvesse uma redução abrupta, a única oferta feita foi por 1:600\$000. Os funcionários municipais alegaram o prejuízo das rendas de Sua Majestade para conseguirem impedir a confirmação do contrato, determinando que o contratador não trespassasse talho algum a outros marchantes e fosse o único encarregado de abastecer todos os talhos públicos da cidade. ${ }^{123}$

Reclamações não faltavam: seja por serem acusados de vender nos açougues primeiramente o gado mais magro para deixar os bois gordos para negociarem clandestinamente por um preço maior, ${ }^{124}$ seja as denúncias de venderem quartos de carne fora dos açougues regulados pelo poder municipal. ${ }^{125}$ Dentre os documentos do Tribunal da Relação da Bahia há diversas acusações e penas imputadas aos marchantes que cometiam corriqueiramente delitos contra o bem comum. Exemplo concreto foi a prisão de Gregório da Silva Henriques pela reincidência na contravenção de vender a carne por um preço maior do que o valor que havia arrematado. A situação foi considerada tão grave que o marchante foi condenado a pena de degredo para Sergipe Del'Rey. Todavia, devida a sua força de convencimento e o pagamento de $10 \$ 000$ para as despesas na cadeia, foi absolvido. ${ }^{126}$

Não à toa, muitas vezes os marchantes foram confundidos com os contrabandistas. Nos documentos coevos três eram os termos usados para qualificar os agentes mercantis que cometiam ilegalidades no comércio de carne em pé ou carne verde: forminas, contrabandistas ou atravessadores. $\mathrm{O}$ termo atravessador certamente era o mais comum. Utilizado inicialmente para qualificar o ato irregular de comprar a mercadoria na estrada ou porta de fazenda e revender por um preço mais elevado, a palavra atravessador começou a ser empregada com mais frequência quando do momento de estabelecimento do registro de entrada de gado em Capuame e a obrigatoriedade de todas as reses passarem por lá antes de chegarem ao matadouro público. O atravessador era, portanto, aquele que descaminhava os bovinos, deixando de registrá-los na feira de Capuame, sonegava o imposto de \$500 réis por cabeça de gado, matava e cortava o gado em açougue clandestino e vendia os talhos em espaços irregulares. O atravessador também era aquele que comprava as reses estropiadas no meio do caminho ou nas portas das fazendas por um preço baixo, entrava na feira de Capuame se dizendo o verdadeiro dono do rebanho (fazendo se passar por criador) para conseguir cortar a carne legalmente no matadouro de Salvador. ${ }^{127}$

123. AMS. Atas da Camara (1684-1700), vol. 6. "Termo de resolução e assento que se tomou sobre a arrematação dos talhos" p. 310. 11 de abril de 1696.

124. AMS. Atas da Camara (1684-1700), vol. 6. "Termo de resolução que se tomou sobre o preço da carne" 10 de março de 1697. p. 238.

125. AMS. Atas da Camara (1700-1718), vol. 7. "Termo de vereação [...] sobre se devassar dos marchantes venderem quartos de carne fora dos açougues [...]" 11 de novembro de 1702. p. 124.

126. APEB. Secção Colonial. Tribunal da Relação. Maço 501 (1707-1711), fl. 190.

127. É comum a historiografia brasileira confundir o atravessador com o comerciante regular, todavia, Fernand Braudel e Edward P. Thompson já haviam atentado para o carater ilegal da atividade daquilo 
Dificilmente o atravessador passaria por Capuame com gado roubado. Possivelmente uma boiada furtada precisava ser comercializada em outro espaço menos visado. O fruto do crime podia ser vendido nos engenhos do Recôncavo (sempre necessitados de bois para manter as unidades produtivas funcionando) ou abatido de modo clandestino. As marcas de ferra dos bois e vacas denunciavam a origem do rebanho. Mesmo que o vestígio fosse retirado, era de se estranhar que uma quantidade grande de animais chegasse ao mesmo tempo com um sinal faltando. Além disso é necessário lembrar que os crimes ocorridos nos sertões e estradas certamente eram noticiados com uma considerável rapidez. De boca em boca, nas portas de armazéns e tavernas sempre frequentados por homens das estradas, as notícias com certeza seguiam com mais velocidade do que o moroso palmilhar das boiadas.

Mesmo em meio a todas as dificuldades que os funcionários régios tinham de efetivar o abastecimento e de tentar regulamentá-lo, o contrabando era o maior fantasma que assombrava a municipalidade, além evidentemente de ser a grande justificativa para qualquer deslize ou falta de equilíbrio que momentaneamente ou a longo prazo interferissem no abastecimento de Salvador. O contrabando e os descaminhos do período colonial ainda precisam ser melhor analisados pelos historiadores. Passo fundamental já foi dado por Paulo Cavalcanti de Oliveira Junior em "Negócio de Trapaças" ao problematizar o contrabando de ouro efetivado entre os anos de 1700-1750 na América Portuguesa. Em pesquisa de fôlego, o autor demonstra quão estruturante era o contrabando enquanto prática generalizada e afirmadora dos caminhos e do controle constituído. "É o caminho que convida ao descaminho". 128

Evidente que todos os negócios e cálculos de rentabilidade deveriam levar em conta o contrabando. Todavia, a lucratividade deste tipo de atividade comercial é dificilmente mapeável devido ao seu caráter essencialmente ligado a extra oficialidade. Mas por outro lado, conseguimos de modo relativamente tranquilo levantar os participantes e as redes de contrabando que contavam com o apoio discreto de grandes figuras das elites coloniais: isso vale também para o comércio de carne.

Devido a quantidade enorme de acusações e processos, os nomes dos contrabandistas e atravessadores aparecem com certa frequência entre os documentos vinculados ao poder público. Temos também de levar em consideração que era costume na colônia o incentivo às denúncias. Diversos foram os editais e bandos afixados que estipulavam uma recompensa àqueles que denunciassem às autoridades todos os tipos de esquema de desvio: as famosas delações premiadas. Isso ocorreu nos sequestros de cargas para a região do ouro, nas embarcações negreiras chegadas aos portos mais movimentados da América Portuguesa e também para o comércio de gado vindo dos sertões baianos em direção à Salvador ou Minas Gerais. O que

que os homens do séculos XVIII chamavam de atravessador. Fernand Braudel. op. cit. ; Edward Thompson, op. cit.

128. Paulo Cavalcanti de Oliveira Junior. Negócios de Trapaça: Caminhos e descaminhos na América Portuguesa (1700 - 1750). USP, São Paulo, 2002, p. 90. 
mudava muitas vezes era o órgão responsável pela fiscalização e evidentemente o volume do comércio vinculado a cada um dos setores. $\mathrm{O}$ incentivo para que as denúncias ocorressem vinha não só na forma de remuneração, mas também na forma de recompensa paga ao delator com parte da mercadoria resgatada. ${ }^{129}$

Em carta de 23 de abril de 1712 ao capitão-mor Domingos Alves, o governador-geral afirma ter recebido a notícia de que o gado vindo dos sertões chegava ao distrito de Capuame, onde os atravessadores compravam boiadas inteiras de gado de alta qualidade, levavam para várias partes da cidade e do Recôncavo, matavam e vendiam os talhos nas praias por um maior preço que a dos açougues. ${ }^{130}$ Preocupado com os atravessadores atuantes nas proximidades de Capuame, o governador-geral escreveu em agosto de 1725 ao futuro superintendente da Feira, Capitão Luiz Pereira de Almeida, alegando saber que um dos mais acérrimos, insistentes e prejudiciais contrabandistas era Francisco Rodrigues que deveria ser remetido para a cadeia da cidade imediatamente. ${ }^{131}$

Em dezembro de 1725 foi a vez do Coronel Manuel de Brito Casado arcar com a responsabilidade de armar uma emboscada e prender a qualquer custo "Miguel Rodrigues, homem que vive de atravessar gado pela beira do Itapecuru e Tucano". Deveria ser remetido com segurança à cidade da Bahia de Todos os Santos. ${ }^{132}$ A intenção era castigar todos aqueles "atravessadores que reverentemente zombam e abusam das leis do Reino e posturas do Senado ".133

Não nos iludamos: assim como nos dias de hoje os desvios eram feitos também por funcionários régios e não são poucos os casos em que marchantes foram acusados de acobertar ou participar diretamente dos desvios das boiadas destinadas ao abastecimento de Salvador. Segundo nos faz crer a carta de janeiro de 1704 remetida ao Juiz de Fora, a falta de carne para abastecer a população da capital não era devido a ausência de produção ou incompetência na condução executada pelos criadores vindos dos sertões. A culpa foi posta nos marchantes que cometiam excessos de modo escandaloso. Pedia para que não houvesse nenhum recurso a indulto ou privilégio para aqueles que fossem considerados culpados. Dentre os suspeitos estavam os marchantes "António Francisco, João Pinheiro e Cristóvão de Medina, pois me consta que entre todos são estes os mais compreendidos e também um Diogo que por sobrenome não perca"134

\footnotetext{
129. Sobre os autos de denunciação e tomadia, ver: Angelo Alves Carrara. Minas e Currais. Produção Rural e Mercado Interno de Minas Gerais (1674-1807). Juiz de Fora, 2007, p.125.

130. DH. "Portaria para o Capitão-mor Domingos Alves fazer vir para esta cidade todo o gado que chegar ao distrito de Capuame" 23 de abril de 1712. vol. 53, p. 160 .

131. DH. "Carta para o Capitão Luiz de Almeida." 31 de agosto de 1725. vol. 72, p. 163.

132. DH. "Carta que se escreveu ao Coronel Manuel de Brito Casado" 10 de dezembro de 1725. vol. 72 , p. 242.

133. DH.“Carta que se remeteu ao Senado da Câmara desta cidade. ”vol. 87, p. 185.

134. DH. "Carta que se escreveu ao juiz de fora desta cidade." 11 de janeiro de 1704. vol. 87, p. 180.
} 
A carta do governador-geral remetida ao Juiz de Fora em 23 de julho de 1723 torna-se emblemática nesse sentido:

"Remeto a Vossa Mercê as duas cartas inclusas que ontem à noite me chegaram ao
mesmo tempo, uma do Capitão Antônio Alves de Matos, outra do Capitão Antônio
Coelho de Afonseca, e conferidas ambas acho tão disformes uma da outra que há
noventa, e quatro cabeças de diminuição nas obrigações também inclusas dos
marchantes, não poderá haver dúvida, mas sem de cabeças como tenho dito, porque o
Capitão Antônio Coelho de Afonseca diz que vêm quatrocentas, e oitenta, e oito
cabeças e o capitão Antônio Alves de Matos trezentos e noventa e três, em cujos
termos, Vossa Mercê mandará fazer a diligência possível, afim de que se examine este
erro, que talvez poderá nascer do uso, e estilo dos atravessadores [...] E parecia-me
que para se evitar devia estar um Almotacel no Curral examinando os quartos que
saíam dele, para depois se conferirem com o Almotacel que estiver no açougue,
porque me consta que os negros que transportam a carne deixam muita parte dela no
caminho."135

Em 1727, parece haver uma virada na política fiscal da Câmara Municipal com o evidente intuito de coibir o contrabando e garantir uma maior arrecadação para seus cofres. Parte desta virada estava relacionada com o aumento do montante em dinheiro que a municipalidade deveria enviar a Portugal para custear as dívidas que a Coroa adquirira com os gastos para o casamento dos príncipes. Inclusive, os casamentos reais eram uma das grandes justificativas para o lançamento de novos impostos sobre a carne verde.

E novamente enfatizo: não por coincidência, no ano de 1727 que a feira de Capuame foi institucionalizada e recebeu um registro de entrada de gado para garantir a melhor arrecadação. No mesmo ano, foi lançado um novo imposto sobre a carne. Mandaram fazer uma casinha na porta do açougue. Ali ficaria um fiel da balança e um escrivão que dariam conta e cobraria por toda a carne que fosse comercializada. ${ }^{136}$ A partir daquele momento, o gado deveria obrigatoriamente sair de Capuame e ir direto para o curral ou matadouro público. Evidente que isso não ocorria na totalidade dos casos, sendo inúmeras as denúncias de arrebanhamento ilegal de gado em lugares não oficiais. Com a vinda das novas medidas fiscais, a tendência do contrabando não foi diminuir e sim buscar meios mais estruturados e sofisticados para desvios.

Em 1734, o meirinho Antônio Botelho recebeu a ordem para ir com alguns soldados do corpo da guarda principal até uma roça no alto de Nossa Senhora de Monserrath (próximo ao bairro soteropolitano da Ribeira) apreender todo o gado que ali estivesse e enviar preso para a cadeia os donos das reses. ${ }^{137}$ No mesmo ano de 1734 apareceu uma nova ordem agora para desmantelar um espaço talvez mais estruturado de contrabando.

135. DH. "Para o Juiz de Fora ". 23 de julho de 1723. vol. 45, p. 105.

136. DH. "Provisão da serventia do ofício de Escrivão da Arrecadação do novo imposto na carne provido em Inácio Francisco Barbosa." 16 de julho de 1727. vol. 48, p. 5 e DH. "Portaria concedida a José Delgado para servir de fiel da Balança do Escrivão da Entrada da Carne " 20 de agosto de 1727. vol. 48. p. 34.

137. DH. “Portaria para o Meirinho Antônio Botelho" 10 de dezembro de 1734. vol. 76. p. 23. 


\begin{abstract}
"Tenho informações certas e verdadeiras, de que no sítio de São Caetano se cortara carne nas duas semanas passadas não vindo da feira nem uma só rês para o termo como me constou do registo, o como também nesta se praticou o mesmo porque toda a que chegou veio para esta cidade e sei com toda a certeza que naquele sítio está gado para se cortar e vender às pessoas que dali se costumam prover ordinariamente com prejuízo grave do bem público e rendimento do Donativo Real. Ordeno ao Meirinho Sebastião de Ávila Vareiro vá com os soldados que lhe parecer amanhecer amanhã ao referido sítio usando do disfarce e cautela que entender e fazendo com toda a exação o exame e diligência necessária nos currais, casas, senzalas, e ainda no mato em que houver suspeita estará gado ou carne, fará apreensão em tudo quanto achar, e juntamente nos pesos e balanças prendendo as pessoas que lhe constar pertencem e as que se ocuparem nesta administração, conduzindo-as para a cadeia à minha ordem, e a carne, gado pesos e balanças a do Senado da Câmara, tomando para esta condução a gente que lhe fôr necessária para se lhe pagar o trabalho e sucedendo não achar carne alguma, fará digo alguma cortada nem também rês pronta e disposta para se matar fará toda a diligência por averiguar se naquelas vizinhanças está algum gado que não seja de criar, e se possa presumir que é de açougue e nele fará apreensão na referida forma, e esta diligência lhe hiei por muito recomendada. "138
\end{abstract}

Em abril de 1752, o Capitão Joseph Luis da Silva foi acusado de ser atravessador de gado atuante na feira de Capuame. A queixa foi apresentada pelo escrivão do registro de entrada de gado, João Moreira Velho, na primeira quarta-feira do mês de abril. Interessante observar no documento a utilização do termo traficante enquanto sinônimo de contrabandista e atravessador:

"se opunham vários atravessadores e traficantes a comprar gado contra a forma do regimento e com o nome de criadores e a fim mais: que o capitão Joseph Luis da Silva o descompusera com palavras injuriosas por causa dele dito escrivão lhe estranhar a forma das compras do gado que fazia para os [...] nesta cidade."139

Sobretudo a partir da década de 1790 passou a ser mais comum encontrar entre os documentos compulsados o termo formina para qualificar os homens envolvidos com o contrabando de carne verde. A denúncia foi feita por alguns marchantes que estavam sendo prejudicados pela atuação de atravessadores influentes que chegavam a pagar funcionários públicos para acobertar as irregularidades. Segundo o relato produzido pelos negociantes, os forminas compravam os cabeceiras (ou seja, as reses mais fortes e gordas) nas estradas antes de chegar na feira de Capuame. Entravam em Salvador pelo mar com auxílio de embarcações e cortavam carne "a enxerga". Se não bastasse todos os registros de entrada de gado existentes nos sertões, propuseram que o Ouvidor da Comarca de Jacobina fiscalizasse todo o movimento de boiadas na região e emitisse juntamente a cada rebanho uma guia contendo o número das reses que deviam chegar diretamente na feira de Capuame. ${ }^{140}$

Manoel Afonseca Rego, moço, branco, solteiro, morador na freguesia da Mata de São João foi acusado em maio de 1794 de cometer irregularidades no

138. DH. "Portaria para o Meirinho Sebastião de Ávila Vareiro" 26 de novembro de 1734. vol. 76. p. 37.

139. AMS. Circulares da Câmara (1726-1819). 19 de abril de 1752., fl. 37.

140. APEB. Maço 201-14. Correspondência recebida pelo governo. Senado da Camara da Bahia (17831799). "Representação dos marchantes sobre os motivos da falta de carne das últimas semanas." 13 de setembro de 1797. 
comércio de gado. Era comum ao administrador da feira de Capuame, o capitão Manoel Henrique, permitir a alguns homens ir até os sertões comprar e puxar boiadas para a cidade nos momentos de carestia. Manoel Afonseca Rego conseguiu a autorização para comprar gado no sertão dos Tocós, todavia, o capitão Manoel Henrique acusava-o de ter comprado quinhentas cabeças de gado no registro do Saco do Moura e chegado em Capuame apenas com sessenta e oito reses, configurando-se uma contravenção. $\mathrm{Na}$ ocasião, o atravessador comprou o gado por $6 \$ 500$ e vendeu na feira de Capuame pelo preço comum de $8 \$ 1000$ por cabeça. Um dos criadores de gado que tinham vendido sua boiada ao atravessador era filho do capitão-mor do sertão de Santo Sé. Disse ser a primeira vez que estava conduzindo gado até lá e ter sido enganado quanto ao verdadeiro preço com que os bovinos estavam sendo comercializados em Capuame. Acabou vendendo por um preço muito menor ao atravessador. Para reaver o prejuízo pedia as autoridades para desfazerem a "venda dolosa". 141

Estudos mais detalhados sobre a dinâmica do contrabando e sua importância econômica ainda estão por ser feitos. Prática constantemente citada como algo a ser combatido, o contrabando era parte estruturante e aprofundador das contradições existentes no interior da sociedade colonial e das relações entre súditos e Coroa. Acelerador da elaboração e aplicação de dispositivos coercitivos, sua alta lucratividade justificava os riscos corridos por inúmeros agentes das mais distintas camadas sociais. Todavia, fica evidenciado pela documentação a participação significativa de funcionários régios e de homens de considerável cabedal nos conluios formados com o intuito de burlar ou ao menos facilitar a sonegação dos impostos, ficando assim aberto o questionamento sobre a importância do contrabando e do comércio ilícito para o processo global da economia na América Portuguesa e a sua imbricação na estrutura estatal já existente.

\subsection{Abastecimento e motins da fome}

Uma das necessidades básicas dos seres humanos é a alimentação. ${ }^{142}$ Dizer isso significa por em relevo que, para o período colonial, mesmo havendo um "sentido profundo da colonização", uma centralidade na produção do complexo açucareiro e demais gêneros destinados à exportação, fazia-se imprescindível a existência do cultivo de suprimentos que dessem conta de alimentar os trabalhadores do eito, das moendas, os feitores, senhores e o restante da população posto que as unidades produtivas tornavam-se altamente especializadas.

141. APEB. Maço 201-14. Correspondência recebida pelo governo. Senado da Camara da Bahia (17831799). 4 de junho de 1794.

142. Henrique Carneiro. Comida e sociedade: uma história da alimentação. Rio de Janeiro, 2003; Luis da Câmara Cascudo. História da alimentação no Brasil: pesquisa e notas. Belo Horizonte, 1983; Jean- Louis Flandrin; Massimo Montanari (org.) História da alimentação. São Paulo, 1998. 
Como bem lembrou Barickman, em Um contraponto baiano, a expansão da economia de exportação exigia o desenvolvimento de um mercado interno. ${ }^{143}$ A especialização da indústria açucareira, a crescente mobilização de homens de armas nos momentos de conflito e o avanço da exploração mineral no interior da colônia requeriam que uma parte considerável das terras e do trabalho fossem direcionados para produzir a "munição de boca". Sendo assim, é difícil manter a imagem criada por Celso Furtado para quem a ampliação dos setores exportadores significava automaticamente uma retração das atividades subsidiárias, tais como a pecuária, na medida em que todos os meios e forças produtivas seriam hipoteticamente direcionados para a produção dos gêneros mais rentáveis. ${ }^{144} \mathrm{O}$ movimento apresentado por Barickman mostra uma dinâmica diametralmente oposta, admitindo inclusive que a escravidão não era um fator limitante para o crescimento da economia interna como pensava boa parte dos historiadores e pesquisadores. ${ }^{145}$

Para o século XVIII é possível dizer que muitas unidades produtivas do Recôncavo baiano dependiam em grande medida dos alimentos produzidos em outras regiões da capitania. Mesmo que houvesse uma obrigação de que cada engenho plantasse uma quantidade determinada de covas de mandioca para garantir a alimentação dos negros escravizados e trabalhadores livres, a insistência das autoridades e as diversas reedições desta medida a partir de 1701 apontam para a possibilidade das leis não terem sido cumpridas. Diferente das fazendas produtoras de tabaco que requeriam por um lado a presença de gado vaccum para adubar a terra e por outro lado a rotatividade com outras culturas para manter a fertilidade do solo, as terras ocupadas pelas lavouras de cana tendiam a ser convertidas majoritariamente para o cultivo deste gênero em específico.

Os Livros de Registro de Entrada de Gado da feira de Capuame faziam referência direta à quantidade de animais destinados a alimentar os moradores dos engenhos do recôncavo baiano. Havia uma parte inteira do livro dedicado a registrar o número de bovinos conduzidos para determinadas fazendas ou engenhos, constando sempre que possível o nome do dono da propriedade. Todo este detalhamento estava relacionado ao controle que os funcionários régios procuravam ter sobre o destino das boiadas sertanejas. Era comum que o gado fosse desviado de seu principal centro consumidor para ser vendido nas fazendas e engenhos das vilas do Recôncavo. Isso porque naquelas paragens os criadores e atravessadores conseguiam garantir um melhor preço para a sua mercadoria semovente. Todavia a vigilância dos funcionários da Câmara de Salvador e seus agentes buscava coibir absolutamente este fluxo devido à diminuição de gêneros alimentícios direcionados a primeira capital e ao prejuízo da Casa na hora da arrecadação do imposto. A única exceção era

\footnotetext{
143. Bert Jude Barickman. Um contraponto baiano: açúcar, mandioca e escravidão no Recôncavo, 1780-1860. Rio de Janeiro, 2003, p. 30

144. Idem, p. 163.

145. Interessante observar como tal diagnóstico envolvendo a compreensão de que a escravidão não se mostrava necessariamente um limite para a expansão da economia de mercado encontra-se em consonância com os estudos que buscam problematizar a linha tênue que separa o trabalho livre do trabalho escravo.
} 
feita aos bovinos que iam diretamente para algumas unidades produtivas. Privilégio de poucos.

As reses que saíam das fazendas sertanejas com destino aos engenhos do Recôncavo precisavam ter uma licença especial do governador-geral. ${ }^{146} \mathrm{O}$ pedido era feito pelo dono da propriedade que requeria uma determinada quantidade de reses. A justificativa era sempre a mesma: a necessidade que tinham do gado de corte ou boi manso para manterem as unidades produtivas funcionando. Mostrava-se como forma mais indicada ao pedido do requerente frisar o fato de que os bovinos eram para consumo próprio e em quantidade tal que não caracterizasse a sua possível comercialização. Evidente que as irregularidades e desvios não deixaram de ocorrer dado a quantidade de denúncias e irregularidades do encaminhamento das boiadas.

Mais um dado importante sobre este fluxo de animais: as licenças eram dadas preferencialmente àqueles que utilizassem como argumento tratar-se do encaminhamento de gado próprio. Ou seja, a maioria dos pedidos deferidos pelo governador eram condizentes às boiadas vindas das fazendas sertanejas dos senhores de engenhos e fazendeiros estabelecidos no litoral. Homens que ao mesmo tempo eram proprietários dedicados à produção voltada para exportação e à criação de gado vaccum com destino a abastecer o mercado litorâneo. Detalhe: este fluxo entre propriedades do mesmo dono era livre do pagamento do imposto de quinhentos réis sobre cada cabeça de gado que deveria passar obrigatoriamente pela feira de Capuame. ${ }^{147}$ Encaminhar uma boiada sertaneja para o Recôncavo baiano sem passar pelo registro de gado, mesmo que se tratasse de bovinos não destinados à venda, era considerado crime resultando na possibilidade de confisco dos animais.

Dentre os senhores de engenho que passavam boiadas diretamente para o Recôncavo baiano sem pagarem os impostos na feira de Capuame estavam os irmãos Cristovão, Thomé Lançarote e Antonio da Rocha Pitta (donos de inúmeras fazendas na região do sertão do Rio São Francisco na partes de Pernambuco, tais como Cabrobó) ${ }^{148}$, "Mestre de campo da Torre" (família dos grandes sertanistas da casa da Torre), os donos do engenho da Mata (herdeiros da Casa da Ponte), engenho da Pitanga, engenho de São João, engenho de São Paulo, engenho Novo de Cotegipe. Engenhos de Curnubusu, Jacaracanga, Pirajá, Paripe. As donas de fazendas e engenhos Dona Rita Xavier, Dona Maria da Vargas, Dona Ana Maria Lacerda. Capitão Vitorino de Argollo, Mestre de Campo Miguel Jerônimo Argollo, Antonio Teixeira Barbosa (senhor do engenho da Passagem) e Antonio Gomes Ferrão Castelo Branco (senhor do engenho Mombaça e fazendas no sertão do Porto da Folha). Senhor de engenho João Francisco da Costa, Capitão José Luis da Roxa Dorea, o

\footnotetext{
146. Sobre as solicitações feitas ao governador-geral, ver: $A M S$. "Ofícios do Governo"(1712-1737).

147. Antonio Gomes Ferrão Castelo Branco fez referência ao despacho concedido pelo vice-rei em julho de 1752. Antonio Gomes Ferrão Castelo Branco. Borrador em que lanço todas as cartas que escrevo, principiado em agosto de 1742, estando na Babia. São Paulo, Coleção Mindlin. Transcrito por Rosana Gonçalves sob orientação da Profa Dra. Mary Del Priore e gentilmente cedido pelo Prof. Dr. Istvan Jancsó. fl. 59.

148. APEB. Thomé Lançarote Pitta. Capital 03/1035/1504/01.
} 
fazendeiro Dr. Adriano Antunes e o capitão Manuel Oliveira Barrozo, Francisco José Duarte, João Tavares.

O caso de Antonio Gomes Ferrão Castelo Branco é o mais facilmente acompanhável por ter restado o Borrador em que o senhor de engenho e fazendeiro transcrevia parte de suas correspondências e anotava as informações mais relevantes sobre a vida de seus familiares e os dados relacionados aos seus negócios. ${ }^{149}$ Assim como vários senhores de engenho que possuíam simultaneamente fazendas sertanejas, Antonio Gomes Ferrão Castelo Gomes havia herdado as propriedades interioranas de seus ancestrais envolvidos com o devassamento dos sertões e a guerra dos Bárbaros. O primeiro membro da família a se interiorizar foi o sertanista Pedro Gomes, avô de Antonio Gomes. Foi um prático do sertão, atuante na guerra contra os holandeses e presente nos conflitos contra os indígenas próximo ao sertão do rio São Francisco. Em recompensa ao extermínio perpetrado, recebeu as terras além rio São Francisco denominadas Porto da Folha. Como estratégia para que as terras não fossem desmembradas ou capturadas em momento de execução de dívidas adquiridas para o financiamento do decadente engenho Mombaça, o coronel Alexandre Gomes, filho do sertanista e pai do autor do Borrador, recorreu ao sistema de morgadio. ${ }^{150}$

Não foi possível saber se os engenhos foram adquiridos antes ou depois das empreitadas de Pedro Gomes como sertanista. Tanto é plausível que o coronel tenha primeiro conseguido as terras sertanejas, estabelecido fazendas de gado e depois comprado o engenho litorâneo, como também é viável que o coronel Pedro Gomes já fosse um senhor de engenho quando recebeu as terras do Porto da Folha. Seria interessante um levantamento sobre a ordem cronológica com que os senhores de engenho adquiriram suas terras sertanejas e litorâneas. A partir de tais dados seria possível saber melhor sobre o papel da pecuária para a reprodução da economia açucareira. Por ora, o que podemos afirmar tendo por base as informações deixadas por Antônio Gomes Ferrão Castelo Branco é que a economia pecuária teve um papel importante para os senhores de engenho, sobretudo nos momentos de entressafra mas principalmente nas épocas de crise e baixa no preço do açúcar.

Primeiramente, temos de lembrar que a consolidação da economia pecuária deu-se em meados do século XVIII, momento no qual muitas das terras já se encontravam doadas e parte delas convertidas em unidades de produção da mercadoria gado. O período coincidiu com uma fase de crise da produção açucareira. Antônio Gomes Ferrão Castelo Branco tomou a dianteira dos negócios depois que seu pai decidiu mudar-se para uma das fazendas do sertão do Porto da Folha, possivelmente para fugir das vexações que as dívidas trouxeram e o estado decadente em que se encontrava um coronel pertencente a elite baiana. Há também indício de que o coronel

149. O livro Borrador produzido por Antonio Gomes Ferrão Castelo Branco a partir de 1748 foi umas das principais fontes utilizadas pela historiadora Mary Del Priore para pensar o âmbito privado na América Portuguesa. Mary Del Priore. "Ritos da vida privada”. Fernando Novais (coord.) História da Vida privada no Brasil. São Paulo, 1997, p. 275-330.

150. Sobre os papéis de confirmação do tombo do Morgado do Porto da Folha. Borrador ..., fl. 16. 
Alexandre Gomes possuía desavenças com o vice-rei estabelecido na cidade da Bahia de Todos os Santos. ${ }^{151}$ No Borrador, percebe-se que o senhor de engenho estava com dificuldades econômicas enormes, cheio de credores querendo executar as dívidas. A alternativa para adquirirem o mínimo de liquidez em momentos de crise era o acesso a cargos comissionados ou a ajuda financeira de parentes mais abastados. Antônio Gomes tentou as duas coisas. Solicitou a patente de sargento-mor através do intermédio de parentes e amigos influentes, recebendo soldo e cavalo com ração após a confirmação. ${ }^{152}$ Escrevia intermináveis cartas para manter correspondência com os parentes abastados que moravam em Portugal não só para intervirem quando fosse preciso mas principalmente para socorrerem financeiramente o familiar empobrecido.

Evidente que este "empobrecido" precisa ser melhor problematizado. Enquanto conceito relativo, a pobreza depende de quem a vivencia e de quais são os parâmetros sociais e econômicos que estão em jogo na hora do julgamento. Por mais que a família de Antonio Gomes Ferrão Castelo Branco estivesse vivendo um momento de dificuldades financeiras, isso não impedia que quisessem reproduzir uma sociabilidade marcada pela pompa e o luxo condizentes com o lugar social que ocupavam enquanto membros da elite. Quando as irmãs de Antonio Gomes, D. Damiana, D. Justa e D. Rufina tornaram-se freiras professas do convento das Mercês, o senhor de engenho não poupou gastos para realizar uma enorme festa com farto banquete. Os gastos foram feitos com o pagamento de coristas para cantarem o dia inteiro, aluguel de órgãos, "timballes, trompas, rebecas e boazes", compra de perus, galinhas, carneiros, melancias, vinho, azeite, tecidos para a confecção de roupas para os membros da família, aluguel de várias negras e negros para auxiliar no preparo da festa, carretos, dentre outros. ${ }^{153}$ Ser um senhor de terras e gentes custava caro.

Mesmo distante oitenta léguas, o coronel Alexandre Gomes continuava a ditar as regras dos negócios que havia deixado sob os cuidados de seu filho Antonio Gomes. Assim como sugere Mary Del Priore, tudo leva a crer que Antonio Gomes não tinha muito tino para os negócios, mostrando-se muitas vezes inapto e desesperado diante dos desacertos das finanças familiares. Com uma enorme frequência os funcionários da fazenda de gado do Porto da Folha trazia correspondências do pai de Antônio Gomes. Muitas delas vinham juntas com as boiadas que desciam constantemente para serem vendidas na feira de Capuame.

No Borrador aparecem as correspondências trocadas diretamente com o superintendente da feira de Capuame. $\mathrm{Na}$ época, o mais alto cargo do registro de entrada de gado estava sob os cuidados de Francisco Xavier de Faria. Chama a atenção a intimidade com que se tratavam nas missivas, indicando inclusive que quem vendia para Antônio Gomes as boiadas vindas do sertão

\footnotetext{
151. Mary Del Priore. op. cit., p. 277.

152. Antonio Gomes já havia ocupado outros postos militares antes. Borrador ..., fl. 88

153. Idem, fl. 155.
} 
do Porto da Folha era o próprio superintendente. Francisco Xavier de Faria ficava encarregado de garantir o melhor preço para o gado de seu "amigo". Se fosse possível deixavam os bovinos pastando o máximo de tempo para se recomporem, ganharem peso e serem vendidos por um preço melhor. Nem todos os criadores tinham esse privilégio na medida em que a manutenção de gado nos pastos de Capuame era um dos motivos apontados para a falta do gênero em Salvador. A ordem era o encaminhamento direto das reses que chegassem à feira. O máximo que podia acontecer era um momento de abundância as reses ficarem pastando para serem encaminhadas nas semanas em que faltasse a quantidade razoável para alimentar a cidade. Depois do negócio fechado, o dinheiro resultante da comercialização da boiada era remetido ao senhor do engenho Mombaça através do crioulo Lourenço dos Santos, moço de confiança - possivelmente escravo - do superintendente da feira de Capuame. O dinheiro acompanhava um recibo assinado por testemunhas com o valor da transação e a data em que foi firmado o negócio. ${ }^{154}$

O dinheiro resultante da venda das boiadas era o que garantia o mínimo de liquidez à Antonio Gomes Ferrão Castelo Branco. E mesmo assim esse pagamento podia demorar até três meses para ser totalmente quitado. A quantia podia ser maior do que o soldo condizente com patente de sargentomor e muito mais palpável do que as vagas promessas de ajuda dos parentes abastados residentes no além mar. Era a produção pecuarista das fazendas de gado localizadas no sertão do Porto da Folha que sustentavam o mínimo de reprodução das condições materiais da decadente família pertencente a elite baiana.

Decerto muitos senhores de engenho que mantinham simultaneamente fazendas de gado sertanejas também conseguiam manter um mínimo de liquidez em seus negócios graças à comercialização das boiadas na feira de Capuame. $\mathrm{O}$ arrendamento das terras das sesmarias que os herdeiros dos sertanistas não conseguiam por conta própria tornar produtivas também podia garantir alguns ganhos aos proprietários. A alta procura por carne verde para abastecer a população sempre crescente da cidade de Salvador, além da possibilidade de vender os animais por um bom preço nas zonas de mineração tanto localizadas no interior da capitania da Bahia quanto nas movimentadas Minas Gerais certamente equilibrava ou pelo menos não deixava que as finanças das famílias abastadas despencassem abruptamente.

A diversificação dos negócios dos membros da elite colonial sempre foi ressaltado pela historiografia. Decerto vários senhores de engenho tinham investimentos em outros ramos lucrativos da economia, tais como o tráfico negreiro e a importação de produtos vendidos nas principais vilas da América Portuguesa. Mesmo sendo a posição e o título de senhor de engenho a garantia do destaque e importância dada aos fidalgos da Casa Real, familiares do Santo Ofício e portadores de hábitos da ordem de Cristo (títulos que Antonio Gomes Ferrão Castelo Branco ostentava), certamente nos momentos 
de crise o que salvava as famílias era a multiplicidade de investimentos. A florescente pecuária do século XVIII certamente era um dos setores que tendiam a colaborar nas finanças das elites coloniais. Muitos dos homens mais ricos da capitania da Bahia tinha parte de sua fortuna representada em gado. ${ }^{155}$ Uma das famílias mais ricas e poderosas da província da Bahia no século XIX, ascendentes de Cícero Dantas, o Barão de Jeremoabo, possuía grandes investimentos na pecuária. Enquanto vários senhores de engenho decretaram falência no final do Império, a família do senador conseguiu manter seu status graças a diversificação dos investimentos. ${ }^{156}$

Portanto, seja como fator de ocupação e efetivação da soberania portuguesa na América, seja como fator de abastecimento e garantia de alimentação à população citadina, seja como setor econômico que permitia a diversificação dos negócios da elite colonial, a pecuária mostrou-se um esfera importante para pensarmos a reprodução econômica e social da colônia dentro de um processo global.

$\mathrm{Na}$ perspectiva do senhor, a pecuária precisava garantir que a produção fosse feita com baixos custos para que não houvesse uma diminuição nos lucros dos fazendeiros ou o aumento no preço do produto final que serviria de alimentação aos trabalhadores das vilas, zonas de mineração, fazendas e engenhos. Aos trabalhadores da pecuária, por outro lado, era necessário garantir que não tivessem gastos com a compra de alimentos, sendo sempre interessante permitir que reproduzissem seus meios de vida passando o mínimo possível pela esfera do mercado. Até porque a baixa remuneração do setor não permitia aos sertanejos integrados no sistema de produção de mercadorias comprar muitas coisas que não o estritamente necessário e impossível de produzir por conta própria. Todavia esta baixa remuneração e a pouca possibilidade de acumularem muitos bens materiais não pode ser confundido com pobreza e muito menos com miséria. Caso não houvesse um fato excepcional, catástrofe, grande seca ou peste que resultasse na perda do rebanho e da produção agrícola é possível que os sertanejos se alimentassem melhor e tivessem mais condições de mobilidade e itinerância que a população livre pobre dos grandes centros urbanos no período setecentista, sempre vigiada, sem terras para produzir seus alimentos e cada vez mais dependentes da venda de sua força de trabalho e da mediação do mercado para se alimentarem sem muita fartura.

Por isso que nos centros urbanos não havia muitas alternativas. Para alimentar os trabalhadores e funcionários régios que se concentravam nas vilas e na cidade da Bahia de Todos os Santos só comprando comida produzida majoritariamente em outras áreas. Todavia, este processo de mediação do mercado, da necessidade crescente de recorrer à produção alheia para garantir a alimentação de maior parte da população não pode ser naturalizado pelo historiador. A sociabilidade moderna imposta por uma dinâmica generalizada

155. Maria José Rapassi Mascarenhas. Fortunas coloniais: Elite e riqueza em Salvador, 1760-1808. São Paulo, 1998.

156. Monica Duarte Dantas. Fronteiras Movediças. São Paulo, 2007. 
de busca por mais racionalização e produtividade através da exploração (com roupagem de eficiência) e controle crescente sobre a terra e o trabalho não foram implementadas sem resistência daqueles que estavam sendo diretamente prejudicados pelo processo violento de expropriação e compulsoriedade do trabalho.

Descontentamentos, questionamentos individuais ou coletivos em relação a sociabilidade imposta pela colonização; revoltas, levantes e motins157 nos momentos de crise de abastecimento certamente existiram durante todo o período em que os conflitos sociais organizaram as relações sempre tensas entre colonizados e colonizadores na América Portuguesa. Agressões, homicídios, roubos, fugas, depredações, saque contra os personificadores do poder e da dominação diante de uma situação entendida pela comunidade como injusta fez parte do repertório de homens e mulheres submetidos muitas vezes a um regime de trabalho compulsório, cuja situação limite era a escravidão. Todavia, fora alguns homicídios e crimes contra a propriedade, as revoltas que tiveram por protagonistas membros da população livre pobre, escravizada e não branca durante os séculos XVII e XVIII não são facilmente mapeáveis. Não há um número substancial de devassas e querelas que tenham por motivo de produção penalizar judicialmente os possíveis amotinados ou pretensos responsáveis por qualquer tipo de ação coletiva que pusesse em cheque o poder colonial constituído na capitania da Bahia. Exceto alguns relatos de revoltas indígenas e escravas, denúncias pontuais da existência de quilombos que precisavam ser desmantelados, restaram poucos testemunhos sobre os conflitos deflagrados para o período estudado, inclusive em contexto urbano. ${ }^{158}$ Este quadro mudará no final do período setecentista.

$\mathrm{Na}$ cidade da Bahia e seu recôncavo, composto majoritariamente por negros escravizados e população livre pobre, as contradições e dificuldades em manter o controle sobre amplos setores da sociedade entendidos como inimigos em potencial - devido ao regime de violência cotidiana a qual estavam submetidos - causava o pânico da elite branca. ${ }^{159} \mathrm{O}$ medo de uma rebelião ou

157. De acordo com Adriana Romeiro, a diferença entre levante e motim estava no carater premeditado com que os levantes eram antecipadamente orquestrados, distoando da espontaneidade dos motins. Adriana Romeiro. “Os rumores na Guerra dos Emboabas.” Júnia Ferreira Furtado (org.). Sons, formas, cores e movimentos na modernidade atlântica. Europa, Américas e África. Belo Horizonte, 2008, p. 78.

158. No decorrer das anotações produzidas pelo capuchinho francês Martinho de Nantes durante a sua visita aos aldeamentos dos sertões próximos ao rio São Francisco, chama atenção a história de uma revolta indígena que resultou na morte de oitenta e cinco brancos e negros escravizados das fazendas de gado já estabelecidas na região. "Relação de uma guerra em que tive que ir, por ordem do governador da Bahia, com os índios de nossas aldeias, para reprimir o furor dos servalgens que, numa noite, mataram, no rio de S. Francisco, oitenta e cinco pessoas, tanto portugueses como negros, nas suas próprias casas." in: Pe. Martinho de Nantes. Relação de uma missão no Rio São Francisco. São Paulo, 1979 , p. 49.

159. Sobre a relação entre a população majoritariamente escravizada das áreas de produção açucareira: "Quadro demográfico bastante propício à eclosão de movimentos coletivos de resistência escrava, como a experiência posterior do Caribe inglês bem o demonstraria." Rafael de Bivar Marquese. "A dinâmica da escravidão no Brasil: resistência, tráfico negreiro e alforrias.” Novos Estudos - Cebrap, 2006, n. 74 , p. 107-123. 
de crimes individuais justificava a edificação de todo um aparato coercitivo efetivado, por exemplo, na tentativa de controle e vigilância sobre a população não branca para garantir que a obediência e a mobilização do trabalho tivesse continuidade. Mas o sossego e a estabilidade necessária para o bom funcionamento da sociedade, tendo por parâmetro a consciência de que cada um possuía um papel determinado a cumprir dentro do corpo social, não foi conquistada somente com o uso da violência direta. Diversos mecanismos operavam no sentido de promover a internalização de valores consoantes com a postura docilizada, tão desejada e compatível com os interesses do Estado e da Igreja para garantir a reprodução de uma determinada relação na qual a ordem e a obediência dos súditos devia imperar. A alforria aos escravizados bem comportados era sempre colocado com uma possibilidade àqueles que não se mostrassem como insubordinados. O temor à "justiça” e à lei divina sempre reiteradas através das punições exemplares - pesava sobre a consciência daqueles criados dentro deste registro de penalização dos comportamentos desviantes. ${ }^{160}$

Entre os séculos XVII e XVIII de fato muitas das resoluções dos conflitos estavam pautadas no uso da violência direta por parte dos senhores/proprietários e homens de patente com o consentimento total das autoridades régias centrais, a quem estavam diretamente subordinados. Quando uma revolta se aproximava do território ocupado pelos brancos ou quando recebiam a notícia da formação de quilombos na vizinhança das terras já dominadas pelos colonizadores, a ordem geral era o desmantelamento imediato da organização, mantendo toda a cautela possível para que as táticas empregadas contra os insurgentes não fossem anunciadas antecipadamente para a parte contrária. ${ }^{161}$ A não ser em casos extremos, são poucas as denúncias de abusos cometidos por funcionários do governo ou pelos militares responsáveis por executarem as diretrizes básicas necessárias para a reprodução do poder metropolitano na colônia. As queixas de missionários e familiares do Santo Ofício em relação aos desmandos do grande sesmeiro Garcia D'Ávila contra indígenas, população livre e seus escravos nunca foram suficientes para colocar o coronel no rol de culpados. ${ }^{162}$

Para os sertões baianos setecentistas, por exemplo, a resolução de conflitos envolvendo a população indígena, negros fugidos ou livres pobres que não se subordinavam aos grandes sesmeiros e autoridades régias era feita na base da bala. ${ }^{63}$ Não havia nenhum tipo de crise ou necessidade de produção de documento que descrevesse ou justificasse o ocorrido. $\mathrm{O}$ tratamento para os inimigos internos e insubordinados era esse. Fora os

160. Flávio Gomes; João José Reis (org.). Liberdade por um fio: história dos Quilombos no Brasil. São Paulo, 2005.

161. DH. "Regimento que levou Fernão Carrilho que foi por Capitão para fazer entradas aos mocambos de Geremoabo." 21 de maio de 1669.

162. Pe. Martinho de Nantes. Relação de uma missão no Rio São Francisco. São Paulo, 1979, p. 71; Luiz Mott. "Tortura de escravos e heresia na Casa da Torre". Babia: Inquisição e Sociedade. Salvador, 2010, p. 63-97.

163. Stuart Schwartz. Burocracia e sociedade no Brasil Colonial: a suprema corte na Babia e seus juízes (16091751). São Paulo, 1979. 
constantes pedidos de contingente para auxílio militar durante os conflitos mais longos, envio de mantimentos, armas e munições, solicitações de patentes e mercês delegadas aos membros mais destacados das operações militares destinadas a exterminar grupos insurgentes e de comportamento desviante, mais nenhum tipo documental que relatasse tais manobras restou. Não havia litígio entre as partes, até porque em última instância, tanto na guerra dos bárbaros quanto nos inúmeros extermínios de quilombolas, as partes envolvidas eram por um lado os coronéis, mestres de campo, capitãesmores e capitães do mato (personificando e executando as diretrizes impostas pelo Estado), e por outro, os povos vistos como empecilho para o bom desenvolvimento da colônia e portanto passíveis de serem exterminados, ou seja, os índios brabos, negros fugidos, que destoavam do projeto político que as elites tanto se esforçaram para efetivar. Uma parte imbuída de plenos poderes e portadora do aval do Estado e a outra parte alijada de qualquer tipo de direito e entendida como alheia à comunidade cristã/colonial. Sendo assim, não fazia sentido e não havia necessidade de abertura de nenhum tipo de averiguação que resultasse em produção de documentos sobre o ocorrido no sentido de punir qualquer tipo de excesso. Possivelmente podemos estender esta lógica também para explicar a falta de registro da maior parte dos motins e revoltas nas regiões mais movimentadas e próximas do litoral, onde também predominava a população pobre e não branca. ${ }^{164}$

Interessante perceber que a história do século XVIII na Bahia foi marcada por dois momentos emblemáticos: Revolta do Maneta e a Conjuração Baiana. Fora estes dois eventos, não há mais nenhum episódio digno de lembrança, no que tange a memória das revoltas e insurreições da capitania. Com exceção dos Motins do Sertão, deflagrados na região do Rio São Francisco, na fronteira com a capitania de Minas Gerais, mais nenhum momento de revolta e conflito, salvo engano, resultou na abertura de devassas ou querelas tão investigadas e conhecidas pela historiografia. Não houve outras rebeliões ou revoltas durante o século XVIII na extensa capitania? Pouco provável. Possivelmente algumas características comuns aos três acontecimentos expliquem tal fenômeno. Primeiro e o mais importante: é de chamar a atenção que os três conflitos contassem com a presença de membros da elite e setores médios da população. Este dado marca logo de início a diferença entre os três momentos registrados e os outros conflitos existentes no período, a saber, a guerra dos bárbaros e o extermínio de quilombos espalhados pelos sertões baianos, fora os outros motins abafados antes mesmo de terem deixado registros escritos. Partindo então da ideia de que existia uma lógica para a produção de relatos e documentos sobre os crimes e revoltas ocorridas até o século XVIII, é possível observar mais uma exceção que reforça a regra. A própria experiência do combate ao Quilombo dos Palmares (bem na passagem do século) contou com uma produção extensa de informações escritas devido principalmente às dificuldades de sucesso das manobras militares e também a existência de disputas internas entre os

164. Sobre a pobreza e a vadiagem em Salvador, ver: Walter Fraga Filho. Mendigos, moleques e vadios na Babia do século XIX. São Paulo/ Salvador, 1995. 
homens de patentes mais destacados arregimentados para desmantelar a duradoura experiência quilombola. Sertanistas entraram em uma série de litígios para garantir acesso a honras e mercês condizentes com a sua participação no episódio mais rememorado do final do século XVII, resultando na produção de uma quantidade significativa de relatos $e$ documentos. ${ }^{165}$

Pensando especificamente na relação entre crises de abastecimento e revoltas da população, temos alguns indicativos e mapeamentos que apontam para um desenho da cidade da Bahia de Todos os Santos como um espaço nada tranquilo, marcado pelas tensões sociais e contradições intrínsecas a um mundo cindido. Quarteladas, revoltas de soldados e a recusa sistemática ao recrutamento compulsório a que os homens pobres estavam submetidos também foram alguns dos episódios que prevaleceram como momentos de insubordinação da população colonial. Evidente que das diversas práticas de contestação da ordem vigente, restou para a posteridade somente os casos mais espetaculares e com consequências talvez mais drásticas para o governo colonial.

É preciso ressaltar: as duas grandes revoltas do século XVIII ocorridas na cidade da Bahia de Todos os Santos tinham membros da elite entre seus participantes ativos. Evidente que estes eram somente os apontados como líderes, seguido por uma lista praticamente irreproduzível de homens e mulheres das mais diferentes posições sociais. $\mathrm{O}$ outro elemento que chama atenção do estudioso é o fato de ambas as revoltas terem por pretexto problemas sobre o abastecimento de gêneros essenciais à população e altamente controlados, tais como o sal166 e a carne, aumentando a adesão popular ao movimento e permitindo que o estopim tivesse como desdobramento a crítica generalizada, comum ao final do século, no caso da Conjuração Baiana. ${ }^{167}$

A Revolta do Maneta é retomada pela posteridade a partir do nome de seu "líder", o homem de negócios português João Figueiredo da Costa, apelidado de Maneta. Ocorreu em 1711, após o governador recém empossado anunciar a cobrança de um novo imposto sobre os escravos, mercadorias importadas e o sal. Segundo algumas narrativas, o Juiz do Povo "tangeu a campa" da cidade - um toque de sino que servia para convocar a população no sentido de comunicar os moradores sobre as novas medidas do governo chamando atenção sobre a existência de alguma novidade vinculada à esfera pública. A notícia do aumento do imposto fez com que a população tomasse as ruas, ocupasse a casa do contratador do sal, Manuel Dias Filgueira, e a Casa

165. A ansiedade dos colonizadores era tão grande diante dos combates contra os inimigos que em 25 de fevereiro de 1694 foi resolvido pelos vereadores da Câmara Municipal de Salvador "se fazerem luminárias pela restauração dos Palmares." AMS. Atas da Câmara (1684-1700), vol. 6, p. 239.

166. O sal era considerado monopólio régio. Ver: Myriam Ellis. O contrato do sal no Brasil Colonial. São Paulo, 1955.

167. Istvan Jancsó. Na Babia contra o Império: história do ensaio de sedição de 1798. São Paulo, 1996; Patricia Valim. Corporação dos enteados: tensão, contestação e negociação política na Conjuração Baiana de 1798. São Paulo, 2012. 
da Câmara. ${ }^{168} \mathrm{O}$ descontentamento popular certamente ultrapassava o fato de recair sobre eles um novo imposto. Não que a cobrança de mais um tributo já não fosse em si mesmo motivo para revolta, mas a falta de gêneros básicos devido a concorrência com as Minas Gerais também deve ter influenciado na adesão popular ao movimento. Possivelmente, a revolta tinha como um de seus motivos implícitos disputas internas entre os membros da elite da Bahia. Essa é uma hipótese, uma sugestão que merece estudo à parte. Vários são os detalhes que ainda não foram levantados sobre o ocorrido. Basta por ora dizer que, em um primeiro momento, o aumento do imposto sobre o sal foi suspendido e os envolvidos, perdoados.

A outra grande revolta que abalou a capitania da Bahia no final do século foi a Conjuração Baiana, Revolta dos Alfaiates ou Revolta dos Búzios. ${ }^{169}$ Esta já melhor estudada se comparada a revolta de 1711, também teve entre seus protagonistas homens bem posicionados na sociedade colonial, apesar do grosso dos manifestantes ser da "arraia miúda", como não poderia deixar de ser. Ganhou outras proporções e teve por desfecho a perseguição de alguns envolvidos e o perdão concedido a outros. O critério para a absolvição foi em alguma medida a posição social do culpado, reforçando assim a ideia de que as duas revoltas que marcaram o período setecentista da capitania da Bahia tem em comum uma repercussão e uma quantidade de documentos relativamente maior devido ao envolvimento de homens com uma colocação nada marginal na lógica colonial. Se assim não fosse, nenhuma devassa ou documento do Conselho Ultramarino sobre o assunto teria restado.

Para as demais rebeliões do período, em especial aquelas ocorridas nos sertões baianos, restam muitas vezes fontes que se referem somente as ordens enviadas aos capitães-mores distantes para que capturassem ou eliminassem os acusados. Exceção fortalecedora da hipótese são os chamados Motins do Sertão do rio de São Francisco ocorridos no ano de 1736. Aqui novamente estamos diante de um conflito impulsionado por membros da elite colonial, gerador de inúmeras disputas e consequentemente de documentos que trouxeram para posteridade dados sobre os embates locais entre os potentados. O estopim para os motins foi as disputas de grandes fazendeiros em relação ao abastecimento de gado em pé à vila de Sabará e regiões mineradoras. ${ }^{170}$ Não muito longe dali, cerca de trinta anos antes mais um motim iniciou-se por questões de abastecimento e conflito entre colonizadores em relação ao controle sobre a arrematação dos contratos dos açougues abastecedores das regiões mineradoras: a Guerra dos Emboabas, encabeçado

\footnotetext{
168. Luciano Raposo Figueiredo. Revolta, fiscalidade e identidade colonial na América Portuguesa: Rio de Janeiro, Bahia e Minas (1640-1761). São Paulo, 1996. p. 80; Francisco Carlos Teixeira da Silva. A morfologia da escassez: Niterói, 1990, p. 238

169. Istvan Jancsó, op. cit. ; Patrícia Valim, op. cit.

170. Muitos dos estudos sobre os Motins do Sertão de 1736 vieram no encalço do trabalho emblemático de Carla Maria Anastasia. Vassalos Rebeldes: Violência coletiva nas Minas na primeira metade do Século XVIII. Belo Horizonte, 1998.
} 
pelo onipresente Manuel Nunes Viana, procurador da família do grande sesmeiro Guedes de Brito. ${ }^{171}$

$$
* *
$$

Durante a pesquisa não foi encontrado nenhum tipo de informação referente a falta de alimento, deslocamento de flagelados ou algo que demonstre um cenário sertanejo tomado pela grave carestia. ${ }^{172}$ Evidente que isso não significa que o período foi coberto majoritariamente pela abundância generalizada. Certamente não foi. Mas há indícios de que os sertões baianos do século XVIII sofriam sem dúvida muito menos com as secas e fomes flagrantes e corriqueiras dos séculos posteriores. ${ }^{173}$ Vários são os motivos para a mudança de paisagem que alterou abruptamente a vida de milhares de sertanejos. Por agora, basta levarmos em consideração somente alguns elementos mais importantes. Fora as alterações provocadas por séculos de desmatamento e palmilhar das boiadas (agravando os períodos de seca) ${ }^{174}$, no século XVIII as fronteiras abertas permitiam o deslocamento discreto da população em busca de áreas com recursos mais favoráveis, na medida em que os sertões não eram compostos por condições físicas homogêneas. Os sertões baianos do período setecentista ainda não estavam totalmente esquadrinhados e dominados pelos grandes sesmeiros, sendo possível uma itinerância nos momentos de grandes secas. Todavia, este deslocamento podia contraditoriamente forçar a sujeição da população livre pobre aos grandes fazendeiros que se aproveitavam da dificuldade de acesso à água ou terras férteis para implementar uma sistema de troca de favores em que os agregados podiam ser utilizados enquanto mão de obra disponível e facilmente mobilizável para qualquer finalidade consoante aos interesses dos donos das terras. ${ }^{175}$ A abundância de terras permitia vez por outra o estabelecimento das policulturas. $^{176}$ Leguminosas, frutas, mandioca, feijão, rapadura eram produzidos em complemento à carne de vaca e cabra. Mesmo entre os pequenos sitiantes, detentores de poucos bens materiais, era comum a posse de alguns animais que garantiam a alimentação básica da família.

171. Há uma bibliografia vastas sobre a guerra dos Emboaba, mas talvez um dos artigos mais interessantes e dignos de nota é de Adriana Romeiro. "Os rumores na Guerra dos Emboabas.” Júnia Ferreira Furtado (org.). Sons, formas, cores e movimentos na modernidade atlântica. Eurpo, Américas e África. Belo Horizonte, 2008.

172. As fomes descritas para as regiões de mineração nos primeiros anos do século XVIII estão vinculadas ao fato de serem recentes aglomerações de forasteiros e escravos dedicados a exploração altamente especializada da extração de minérios restando poucas pessoas mobilizadas inicialmente à produção de alimentos, sendo necessário a importação dos gêneros mais básicos.

173. Sobre algumas secas do século XIX, ver: B. J. Barickman. Um contraponto baiano. Rio de Janeiro, 2003, p. 67.

174. Marta Celina Linhares Sales. Estudos climáticos, morfo-pedológicos e fito-ecológicos no núlceo de desertificação de Irauçuba-CE. USP, São Paulo, 2003; Larissa Giroldo. Terracetes de pisoteio de gado mudanças morfo-pedológicas em vertente amostral na bacia hidrogŕofica do rio Jacaré, Serra da Mantiqueira - SP. USP, São Paulo, 2013; Mike Davis . Holocaustos Coloniais: Clima, fome e imperialismo na formação do Terceiro Mundo. Rio de Janeiro, 2002; Henry Diaz e Vera Markgraf. El Niño Historical and Paleoclimatic Aspects of the Southern Oscillation. London, 1993.

175. Renata Rente, op. cit., p. 107.

176. Erivaldo Fagundes Neves. Uma comunidade sertaneja. Da sesmaria ao minifúndio. Um estudo de bistória regional e local. Feira de Santana/ Salvador, 2008. 
O mesmo já não é possível afirmar sobre a população livre pobre dos grandes centro urbanos cuja alimentação ficava ao Deus dará. Dentro de uma sociedade cindida, muitas vezes as camadas menos abastadas só tinham acesso à comida depois de muito trabalharem para outrem, dependendo necessariamente de uma oferta razoável de alimentos possivelmente comercializados e daquilo que o dinheiro conseguia custear para a compra do básico para o seu sustento e de sua família. Tudo isso porque parte da população era cada vez mais alienada da possibilidade de plantar e produzir para si em um ambiente marcado pela tendência a generalização das relações medidas pela mercadoria, pela especialização da produção e a divisão social do trabalho.

No caso dos momentos de crise de abastecimento na cidade da Bahia de Todos os Santos, temos informações sobre a existência de "clamores do povo" e arrombamento dos açougues públicos, fazendo com que as autoridades se vissem obrigadas a intervir e enviar ordens aos seus subordinados para que a falta de mantimentos, tais como a carne verde, fosse rapidamente suprida. Os funcionários régios sabiam perfeitamente que só com um abastecimento em contento a paz poderia voltar a reinar. Se é que em dia ela chegou a sentar em seu glorioso trono.

Em carta de 1702, direcionada aos oficiais da Câmara, o governador reclamava da falta de carne que ocasionou o fechamento dos açougues de Salvador na semana anterior. Tal calamidade tornava-se alarmantemente prejudicial aos cofres públicos nos momentos em que a frota das Naus da Índia estavam no porto da cidade. As embarcações só podiam partir depois que a matalotagem estivesse completa e cada semana em que os barcos permaneciam aportados significava prejuízo para todos os envolvidos com os fretes e transporte de mercadorias. A situação ficou ainda mais grave pois nos dias seguintes chegaram mais navios vindos do Rio de Janeiro sem mantimentos (visto também não conseguirem suprimentos na Baía da Guanabara). A culpa quanto à falta de carne foi colocada nos marchantes por não cumprirem com sua obrigação, descaminhando as boiadas para o Recôncavo, deixando de levar as reses para a capital, sendo que havia gado "empastourado" nas partes mais interioranas da capitania. ${ }^{177} \mathrm{O}$ problema não estava na produção em si.

Uma nova falta de carne no açougue foi documentada para os meses de abril e maio de 1723. Na ocasião, os ministros do Tribunal da Relação da Bahia reclamavam de ter mandado seus escravos e servos ao açougue público para buscar carne. O almotacel não só deixou de servi-los como proferiu palavras injuriosas, além de supostamente optar por servir de carne "as várias negras e outras pessoas inferiores" que também disputavam um talho. O almotacel foi imediatamente chamado na presença dos senadores para justificar tal atitude e ser advertido de que os desembargadores não deveriam

177. DH. "Carta aos oficiais da Câmara sobre mandarem conduzir gados para o povo" 27 de setembro de 1702 . vol. 87 , p. 44. 
deixar de ser fornecidos de carne em hipótese alguma. ${ }^{178}$ Aqui podemos observar a lógica do privilégio operando e se reproduzindo até mesmo na fila do açougue. Levando em consideração o fato de que se nem mesmo os escravos dos ministros foram providos de alimentos, o que podemos pensar para o restante dos mortais não privilegiados?

Talvez por uma questão meramente retórica, por ser um exemplo da situação extrema em que havia chegado os problemas referentes ao abastecimento ou por uma questão de perspectiva social, em geral os documentos que restam sobre o assunto apontam para as dificuldades que membros da elite e funcionários estavam enfrentando para compor a sua alimentação básica. Os problemas para completar a matalotagem destinada às embarcações também aparece como uma demonstração do ponto em que a falta de gêneros na cidade da Bahia tinha chegado. Sendo assim, não é difícil concluir que se os setores mais privilegiados estavam vivenciando momentos de carestia, certamente o grosso da população mais pobre há tempos não via um pedaço de carne em sua panela. Ou seja, se nos documentos restam informações sobre os momentos de exceção nos quais a população mais abastada e favorecida não podia contar com o suprimento de carne verde, isso significa que possivelmente a falta de carne era a regra para a população mais pobre do século XVIII. Daqui podemos pensar na possibilidade de que os tumultos só ocorriam ou eram documentados quando uma parte dos setores médios da sociedade fosse diretamente atingida pela falta de carne verde para a sua alimentação.

Os redatores da representação entregue ao Senado da Câmara em 1797 alertavam para o fato de que o grosso da população não chegava a consumir carne verde. ${ }^{179}$ Era muito possível que os escravos dos engenhos só consumissem carne de segunda e miúdos em momentos de fartura. No caso do Engenho Mombaça de Antonio Gomes Castelo Branco, durante as obras de reedificação e concerto do engenho, casa-grande, alambique e capela, costumavam mandar trazer da feira de Capuame algumas reses da boiada vinda do sertão do Porto da Folha. Todavia, segundo o senhor de engenho, saía muito caro alimentá-los com carne verde devido o preço do gênero, mostrando-se mais em conta fornecê-los carne seca. O único inconveniente era que a carne seca precisava ser comprada com dinheiro, sendo necessário a Antonio Gomes Ferrão Castelo Branco fazer um acordo com o comerciante e pagá-lo somente uma vez por ano, na época das Frotas. 180 Se a baixa monetarização mostrava-se uma limitação para os negócios do senhor de engenho, o que dizer sobre o restante da população que possivelmente não contava com o mesmo crédito que os membros da elite colonial? Para ele, a opção pela carne seca era somente uma possibilidade de diminuir os gastos

\footnotetext{
178. DH. "Portaria para o Senado da Câmara chamar a sua presença ao almotacé que reparte carne ao povo, estranhando-lhe o não ter dado carne aos ministros da relação e que daqui em diante lha dê o dito almotacé." 13 de abril de 1723. vol. 87. p. 182.

179. APEB. Maço 201-14. Correspondência recebida pelo governo Senado da Camara da Bahia (17831799). 8 de fevereiro de 1797.

180. Antonio Gomes Ferrão Castelo Branco. Borrador ..., fl. 50.
} 
com a alimentação da escravaria. Mas será que todos podiam recorrer ao comércio de carne seca?

Mesmo que não houvesse uma produção substancial de carne seca na capitania da Bahia, relatos e fontes documentais mostram que grande parte do produto vinha de outras capitanias. O Maranhão chegou a enviar com frequência a carne seca para a Bahia, ${ }^{181}$ mas certamente o maior fluxo vinha de Pernambuco e capitanias anexas, ressaltando sem dúvida a participação do Ceará como grande produtor. ${ }^{182}$ A carne seca possivelmente, pelo seu menor preço e maior facilidade para ser estocada servia de alimentação mais frequente para a população pobre e para os itinerantes. De fato, em muitas ocasiões os vereadores falavam sobre a falta de alimentos para manter a dieta básica do "povo". Resta saber quem era o "povo" no século XVIIII.

Segundo a Câmara Municipal de Salvador, órgão responsável pela política de abastecimento do centro da capitania da Bahia, o ideal na década de 1730 era a entrada de pelo menos 250 reses por semana no matadouro público. Possivelmente este número aumentou substancialmente no decorrer do século. ${ }^{183}$ Para o século XIX existe a informação de que no sábado, dia oficial do abate, precisavam ser mortos pelo menos 120 animais, ficando uma quantidade de 90 reses para o corte nos outros dias da semana, excetuando os dias de abstinência. Supondo um número máximo e ideal de bovinos abatidos por semana, o cálculo demonstra que o ideal em 1828 era o corte de aproximadamente 660 reses. Pensando que os dois cálculos que temos da quantidade ideal para abastecimento satisfatório de Salvador distanciam-se aproximadamente em um século, levando em consideração que a cidade teve um crescimento demográfico proporcional, é razoável pensar que para a metade do período, ou seja, para a década de 1780 a quantidade próxima ao ideal para satisfazer a necessidade de carne cortada no açougue para alimentar os moradores de Salvador fosse próximo a 455 reses abatidas por semana.

Todavia, devido as constantes reclamações referentes à falta de carne nos açougues é razoável pensar que nem sempre a meta estipulada pelos funcionários régios era atendida. Anualmente a feira de Capuame enviava à Salvador uma média de 20.265 cabeças de gado, segundo a tabela correspondente aos anos de 1785 a 1798. Interessante notar que a média de reses encaminhadas mudou da década de 1780 para a década de 1790 . No primeiro decênio calculado, a média anual foi de 22.207 reses, equivalente a aproximados 445 bovinos abatidos todas as semanas em Salvador. No segundo decênio calculado, a média de reses encaminhada por ano foi de 18.545, contando assim como cerca de 370 reses por semana. Levando em consideração que o ano possui aproximadamente 50 semanas, a cidade contava com o fornecimento de aproximadamente 405 cabeças todos os domingos, quantidade inferior as 455 reses possivelmente necessárias para

\footnotetext{
181. Maria do Socorro Coelho Cabral. Caminhos do gado: conquista e ocupação do sul do Maranhão. São Luís, 1992. p. 157.

182. Leonardo Cândido Rolim. "Tempos das carnes" no Siará Grande. João Pessoa, 2010.

183. DH. "Portaria para o Capitão Luiz Pereira de Almeida" 11 de outubro de 1734. Vol. 76, p. 13.
} 
manter um abastecimento razoável da cidade. Se cada cabeça de gado correspondia a algo em torno de 5 arrobas, 405 cabeças equivaliam a 2.025 arrobas de carne prontas para o consumo. Uma arroba de carne de vaca alimentava aproximadamente 20 moradores. Caso possamos acreditar nos números resguardados pelas fontes documentais, a situação da cidade de Salvador em fins do século XVIII estava longe de figurar como um espaço marcado por uma generalizada crise de abastecimento. Apesar da quantidade de gado comercializada ser menor do que a quantidade estipulada pela municipalidade, não havia uma escassez generalizada para o período inteiro. $\mathrm{O}$ fato é que a comercialização do gênero diminuiu consideravelmente da década de 1780 para a seguinte. De 1791 em diante havia um déficit de quase 35 bovinos por semana para abastecer a cidade. Isso podia significar uma falta próxima a 175 arrobas de carne na praça. Qual parcela da população ficaria sem consumir carne? Certamente não eram os Ministros do Tribunal da Relação, funcionários régios e a tripulação das Naus das Índias. Fácil supor.

O mais grave da situação quanto ao fornecimento da carne verde era a sua irregularidade. Foi possível notar através dos Livros de Registro de Entrada de Gado da feira de Capuame que um mês marcado pela abundância de boiadas vindas dos sertões baianos podiam ser seguidas por meses de penúria. A dependência direta da produção em relação aos fatores climáticos marcavam as economias agrárias de Antigo Regime, caracterizadas pela oscilação da produção a depender majoritariamente do regime de chuvas.184 Uma mudança brusca, fora do previsível, podia significar uma catástrofe. Todavia, é importante frisar que aparentemente os produtores sertanejos conheciam muito bem as alterações possíveis das condições naturais. Todos se preparavam para os períodos de seca anual, derivando daí o amplo encaminhamento de reses para o litoral entre os meses que são exatamente anteriores ao início da temporada cíclica da seca. O problema não eram estes períodos previamente calculados pela população. $O$ desconforto e a preocupação vinham caso o período de seca se transformasse em uma grande seca, ou seja, se depois da seca habitual as chuvas não chegassem e o ciclo não se completasse como previsto.

Todavia, a dificuldade do historiador é saber qual a dimensão social da falta de carne na cidade de Salvador. Se para todo o período há reclamações quanto a diminuição no abastecimento de carne verde e a falta de alimentos para o total da população, é correto supor que Salvador estava a beira do caos alimentar? Será que em alguma medida não havia um certo exagero no discurso por parte das autoridades? Talvez. Lembremos da desconfiança de Angelo Carrara quanto à pretensa decadência econômica da Capitania de Minas Gerais em pleno século XVIII. ${ }^{185}$

184. Francisco Carlos Teixeira da Silva, dedica grande parte da tese "Morfologia da Escassez" ao mapeamento dos debates sobre economias agrárias do século XVII e XVIII. Francisco Carlos Teixeira da Silva, op. cit.

185. Angelo Carrara, Minas e Currais: produção rural e mercado interno de Minas Gerais (1674-1807).Juiz de Fora, 2007, p. 25 e segs. 
Evidente que a oferta não era totalmente uniforme, havendo épocas do ano em que várias boiadas chegavam simultaneamente à Capuame, enquanto havia meses de seca em que se cortava um número mínimo de reses magras, fenômeno observado para todas as culturas agrárias, inclusive para a próspera cidade do Rio de Janeiro.186 Assim como alguns produtos possuem a sua época de produção e colheita, o gado também era pensado enquanto produto que possuía os momentos de safra e entressafra. Esta foi uma realidade até o século XVIII para distintas áreas pautadas pelas economias de Antigo Regime. ${ }^{187}$ Se levarmos em consideração a classificação proposta por Francisco Carlos Teixeira da Silva, em Morfologia da escassez, é possível dizer que a cidade de Salvador passou por momentos de penúria e carestia devido a problemas políticos e faltas sazonais (refletindo na constante alta de preços), mas não por momentos de fome generalizada em que a população inteira padecesse com a falta completa de alimentos. ${ }^{188}$ Isso sem contar a parcela mais pobre da população que certamente vivia em condições de constante penúria em relação ao consumo de carne.

O final do século XVIII para a cidade de Salvador foi particularmente agitado. Segundo Katia Mattoso, o período foi marcado pelo crescimento econômico com relativa prosperidade entre os anos de 1787 e $1821 .{ }^{189} \mathrm{O}$ fenômeno se deu principalmente devido a alta de preço na Europa de gêneros agrícolas tais como o açúcar e algodão. A desarticulação da produção nas colônias americanas que entraram em processo de revoltas e independência, tais como Estados Unidos e Haiti propiciaram à elite da América Portuguesa uma oportunidade de recuperar as décadas de declínio econômico devido a concorrência Antilhana da indústria açucareira. As regiões mais interioranas e secas foram aproveitadas para a introdução do cultivo do algodão, largamente produzido no vale do Mississipi, mas com queda após as lutas travadas na antiga colônia inglesa.

Todavia, a alta dos preços dos gêneros de exportação teve dois impactos evidentes na produção de alimentos voltados para o abastecimento interno: a ansiedade dos fazendeiros em expandir suas fronteiras agrícolas e aumentar a produção fez com que o cultivo avançasse para áreas antes dedicadas essencialmente à mandioca e à pecuária. A alta de preço dos gêneros voltados para exportação (tais como o açúcar e o algodão) forçaram uma elevação geral dos preços na colônia, resultando em um aumento do preço da carne seguido por uma diminuição da produção em áreas mais próximas do litoral convertidas sempre que possível em canaviais ou algodoais. A própria região da feira de Capuame foi amplamente rodeada por canaviais na virada do século XVIII para o XIX. 190

\footnotetext{
186. Francisco Carlos Teixeira da Silva, op. cit.

187. Fernand Braudel. Civilização Material, Economia e Capitalismo. Séculos XV-XVIII, São Paulo, 1998, vol. 1 "O Jogo das Trocas".

188. Sobre a distinção entre fome, penúria e carestia, ver: Francisco Carlos Teixeira da Silva. op. cit.

189. Kátia Queirós Mattoso. "Os preços na Bahia de 1750 a 1930". L'bistorie quantitative du Brésil, 18001930. Paris, 167-182.

190. Rollie Poppino. Feira de Santana. Salvador, 1969.
} 
Os descontentamentos não tardaram em aparecer. Aumentava o número de reclamações e as autoridades régias se debatiam em torno de novos planos e medidas para garantir o mínimo de estabilidade social na movimentada cidade de Salvador. A tentativa de um controle mais eficiente sobre o comércio do gado em pé e a carne verde estimulou a produção de um "Plano" elaborado pelo governador Rodrigo José de Meneses e Castro. Interessante notar que o primeiro Livro de Registro de Entrada de Gado para a feira de Capuame analisado neste trabalho data do mesmo ano, 1784. A preocupação do governador ficou evidente pela quantidade de diretrizes e documentos produzidos concernentes aos negócios da carne. ${ }^{191}$ Possivelmente, o dia 4 de janeiro de 1786 foi de muita festa na região da feira de Capuame. Mostrando o seu emprenho em resolver os problemas corriqueiros com a carestia da cidade, o governador visitou pessoalmente a feira de gado e manteve-se mais próximo dos problemas e das necessidades que o comércio requeria. ${ }^{192}$

Mesmo com novos planos e medidas, as irregularidades no abastecimento insistiam em ocorrer. Como demonstra a representação escrita por algum morador ilustrado da cidade de Salvador em 1797, já era relativamente conhecida na colônia as ideias liberais que agitavam parte da América e da Europa. Naquele momento, os moradores que assinaram a representação entregue ao Senado da Câmara reivindicavam somente uma tomada de decisão pontual: a retirada de qualquer tipo de impedimento comercial referente ao abastecimento de carne verde.

O ambiente de agitação política foi ainda mais estimulado com a fixação em locais de grande circulação de pasquins e boletins contendo referência direta aos conflitos travados dos dois lados do Atlântico. A propagação da ideia de liberdade individual, a assimilação do vocabulário revolucionário causou pânico nas autoridades que se viam rodeadas pelo fantasma das revoluções americana, francesa e haitiana. ${ }^{193}$

Antes da revolta dos Alfaiates, o clima em Salvador já era de insatisfação, ocorrendo frequentemente motins que incluíam arrombamento dos açougues espalhados pela cidade. Muitos são os vestígios de descontentamento generalizado referentes a escassez de gêneros alimentícios para o final do século. Boletins sediciosos e pasquins eram pregados em lugares de maior visibilidade nos momentos de revolta. Durante os conflitos, onze cartazes fora afixados em vários locais da cidade, dentre eles as portas do Açougue da Praia, localizado na cidade Baixa, na movimentada freguesia de Conceição da Praia. ${ }^{194}$ Essa prática de pendurar cartazes contendo dizeres injuriosos com relação às autoridades e grandes comerciantes era comum no período colonial, apesar de poucos cartazes e pasquins serem citados e quase nenhum conservados até nossos dias. É interessante pensar também que para o século

191. AMS. "Livro de Registro de Entrada de Gado" da feira de Capuame. fl. 97 v, 173.

192. Idem, fl. 90.

193. Patrícia Valim. op. cit.

194. Marli Geralda Teixeira. "Revolta dos Búzios ou Conjuração Baiana de 1789: uma chamada para a liberdade". S/d. Disponível em < http://www.educacao.salvador.ba.gov.br/documentos/revolta-dosbuzios.pdf > . Acessado em: 11 de novembro de 2012 . 
XIX há mais estudos consistentes que fazem referência direta ao hábito da população de não deixar que as autoridades pendurassem nos locais públicos as novas medidas e leis. Ler em voz alta ou pendurar em locais de grande circulação informações escritas referentes às novas diretrizes e decretos equivalia a uma publicação da norma. Quebrando as famosas tabuletas ou rasgando cartazes e editais, os rebelados garantiam assim, de forma simbólica/efetiva, que a medida não fosse adotada devido a sua não publicização. ${ }^{195}$

O ano de 1797 parece ter sido particularmente tumultuado para a cidade de Salvador. Em 06 de setembro as ruas foram tomadas pela população com o auxílio dos soldados que causavam "grandes vexames" às autoridades e aos comerciantes por obrigarem todos os vendedores que chegassem na cidade por mar ou por terra a venderem os alimentos pelo preço que eles mesmos estipulassem. ${ }^{196}$ É possível que a decisão dos soldados não fosse totalmente arbitrária havendo alguma espécie de noção de preço justo que estava sendo desrespeitada pelos comerciantes que agiam arbitrariamente causando a fome de uma parte considerável da população.

No domingo anterior os senadores informavam ao governador sobre os tumultos nos açougues do Terreiro de Jesus e no açougue "Grande da Praça". Durante a confusão o cobrador foi gravemente mal tratado, as portas foram arrombadas, retirando a carne dos escravos dos marchantes que conduziam os talhos para os seus senhores. Segundo o documento fazia já um tempo que os açougues eram palco de confusões e tumultos. Disseram ainda que os revoltosos "tem proposto fazer o mesmo com os condutores das carnes em caminho ao açougue e até mesmo o curral que não deixou de ser acometido já."197

Lembremos que dois anos antes militares de baixa patente também arrombaram as portas do açougue da freguesia da Conceição da Praia em um dos momentos de carestia. Roubaram toda a carne do gado recém abatido, cortaram os talhos, ficaram com uma parte da comida e venderam o restante para as pessoas que estavam presentes no momento da ação. ${ }^{198}$

Talvez na documentação do Tribunal da Relação da Bahia ou em alguma fonte referente à entrada de pretensos criminosos ou infratores na cadeia da cidade de Salvador tenha como levantar mais informações sobre acusações vinculadas a protestos e movimentos de insatisfação pontual ou generalizada em relação aos problemas de abastecimento do final do século XVIII.

\footnotetext{
195. Sobre a guerra dos Marimbondos ou Ronco da Abelha, ver artigo de Maria Luiza Ferreira de Oliveira. "Resistência popular contra o decreto 798 ou a "lei do cativeiro": Pernambuco, Paraíba, Alagoas, Sergipe, Ceará, 1851-1852.”. Sobre Quebra-Quilos, ver: Luciano Mendonça de Lima. "Quebra-Quilos: uma revolta popular na periferia do Império." Monica Dantas (org.) Revoltas, motins, revoluçoes: homens livres pobres e libertos no Brasil do século XIX. São Paulo, 2011.

196. APEB. Maço 201-14.Correspondência recebida pelo governo. Senado da Camara da Bahia (17831799). Carta de 06 de setembro de 1797.

197. Idem.

198. APEB. Maço 201-14. Correspondência recebida pelo governo. Senado da Camara da Bahia (17831799). 8 de abril de 1795 .
} 
Todavia, por mais que o tema seja de extremo interesse e importância para a presente dissertação, um esforço desta proporção escapa da problemática central aqui levantada, sendo necessário aguardarmos estudos futuros para conseguirmos traçar um panorama mais seguro sobre estes processos sociais.

Por ora, restou-nos apresentar algumas das informações que foram localizadas sobre os descontentamentos da população quanto ao aumento do custo de vida ou à própria escassez de víveres na cidade da Bahia especialmente para o final do século. $\mathrm{O}$ momento parece ter sido favorável para este tipo de movimentação por alguns aspectos já levantados, tais como a diminuição das áreas produtivas dedicadas ao cultivo de alimentos, a ampliação da constante escassez de gêneros de primeira necessidade para outros setores da sociedade, tais como as camadas médias, a assimilação de uma crítica política e o aprendizado de um vocabulário condizente com as repercussões dos processos revolucionários e de independência no Velho e Novo Mundo.

Aqui temos de algum modo que levantar novamente a questão sobre a divisão social do trabalho que já imperava sobretudo nos centros urbanos, para não falar nas especializadas unidades produtivas do recôncavo baiano. Em especial em meados do século XVIII, a população da cidade de Salvador dependia cada vez mais que seus meios de vida passassem pela esfera do mercado e das trocas. Tendo a percepção de que o acesso e distribuição dos alimentos não era uma questão menor para uma nascente sociedade urbana, é razoável inferir disso que qualquer crise de abastecimento tivessem impactos sociais exorbitantes. Não se trata evidentemente de apontar uma relação direta e mecanicista entre a fome e os conflitos. Esse tema já foi deveras debatido ( mas ainda não esgotado) pela historiografia. ${ }^{199}$ Todavia, sabemos que nestes momentos calamitosos, os processos se aceleram, os ânimos se exaltam e muitos dos rancores e humilhações cotidianos da população livre pobre e escravizada vem à tona na forma de revolta mais efetiva na medida em que a confiança imputada aos governantes enquanto mediadores de conflitos perde o sentido. Não que a resistência, a recusa ao trabalho alienado e o boicote diário não fossem uma demonstração cotidiana do descontentamento social generalizado, mas são nos momentos de movimentos coletivos, mesmo na aparência, que as contradições desta vida social se explicitam, os conflitos tomam outras proporções e geram um momento de aprendizado popular da política.

Vale aqui novamente um adendo: a diferenciação das regiões sertanejas reside no fato da sociabilidade ser mediada por outras questões. Ali não houve motins populares vinculados ao abastecimento pelo simples fato de que este se apresenta como problema só diagnosticado depois que o processo de fechamento de fronteiras se efetiva e que a maior parte da população já não tem mais condições de produzir para si. Para o século XVIII, a população de modo geral conseguia escapar de maneira e em graus diferentes dos

199. Edward Palmer Thompson. Costumes em comum. São Paulo, 2005; João José Reis e Márcia Gabriela D. de Aguiar . "Carne sem osso, farinha sem caroço: o motim de 1858 contra a carestia na Bahia". Revista de História, 135 (1996), p. 133-160. 
desmandos das autoridades coloniais - compreendidas como sesmeiros, fazendeiros e homens de patentes que personificavam o Estado colonial e o processo civilizatório - e podia garantir de algum jeito sua auto produção dos meios de vida com relativa autonomia dependendo das condições objetivas sem que toda a sua sociabilidade fosse mediada por mercadorias.

Faz-se necessário reforçar: a violência dos senhores dos sertões nada mais é do que um objetivação e um desdobramento da violência do Estado. Violência esta necessária para a reprodução do capital na localidade, tanto nos sertões, como na cidade da Bahia, na feira de Capuame ou nas civilizadas metrópoles europeias (apesar da tendência generalizada de expurgar gradativamente o processo de exploração violenta do trabalho para a periferia). Acertadamente, Renata Rente parafraseia a fórmula trinitária de Marx. Terra, trabalho e violência mostram-se como formas socialmente necessárias para a reprodução do capital. ${ }^{200}$ Esta paráfrase é nada mais do que uma contrapartida da análise já publicada por Vera Lucia Ferlini para quem o poder, em sua forma cristalizada, garantia a reprodução social dos senhores. ${ }^{201} \mathrm{O}$ poder aqui pode ser compreendido como uma das facetas necessárias e justificadoras da violência que marca a acumulação primitiva de capital como processo histórico de expansão de um tipo de relação social determinada. Tanto o poder quanto a violência não passam portanto dos dois lados da mesma moeda que garantia aos senhores de escravos e representantes do Estado o devido monopólio da terra e do trabalho e portanto negava paulatinamente à população o acesso direto ao alimento necessário para a sua reprodução diária, condenando-os ao jogo das trocas imposto por uma economia de mercado. ${ }^{202}$ Faz-se necessário portanto desnaturalizar a existência do mercado e da forma mercadoria enquanto mediação social única e exclusiva.

Ora, não é porque os agentes da época não viam o processo como violento que ele não tenha sido. Sabemos que a maior parte das categorias de análise são estabelecidas a posteriori. Esse é o caso da ideia de capitalismo e até mesmo de Antigo Sistema Colonial. Portanto, não se trata aqui de cometer anacronismo. Estamos sim dando uma interpretação com base em evidencia empírica. E diga-se de passagem, nada foi mais empírico do que a quantidade absurda de índios exterminados e africanos desenraizados, para não falar da quantidade de homens livres pobres que se amontoavam em barrancos e moradias precárias na cidade de Salvador. ${ }^{203}$ Não se trata aqui de uma leitura ideológica, a não ser que também admitamos que o discurso dos europeus para justificar o extermínio e o esgarçamento dos laços de comunidades inteiras também o fosse. A não ser que consideremos também que a aparente neutralidade do pensamento liberal também é ideológica e garantidora de sua hegemonia sempre reiterada e reforçada através do escamoteamento das contradições da sociabilidade moderna.

\footnotetext{
200. Renata Rente. op. cit.

201. Vera Lucia Ferlini. Terra, trabalho e poder: o mundo do engenho no Nordeste colonial. São Paulo, 1988.

202. Fernand Braudel. op. cit.

203. Kátia Queirós Mattoso. Babia: uma provincia no Império. Rio de Janeiro, 1992.
} 


\section{CONSIDERAÇÕES FINAIS}

Partir da feira de Capuame foi uma opção para aprofundar os estudos sobre a pecuária nos sertões baianos do período colonial. Sempre entendida como naturalmente atrofiada, marcada pelo atraso e o baixo desenvolvimento das técnicas, a ideia era observar essa região para além dos preconceitos e estereótipos que estigmatizaram por décadas o povo sertanejo. Muito ainda está por ser feito para uma melhor compreensão da feira de Capuame e a pecuária dos sertões baianos. Esta é somente uma contribuição para o preenchimento de uma lacuna e uma tentativa de apontar para a existência de uma economia mais importante e complexa do que a historiografia tem admitido.

O período setecentista parece ter sido de fato o século do ouro também para os sertões baianos dedicados à produção de bovinos. Muitos dos membros da elite colonial possuíam investimentos em fazendas de gado vaccum na tentativa de diversificar os negócios. Vários homens conseguiram entrar em fluxos mercantis altamente rentáveis como o tráfico negreiro, produção de açúcar, mineração e contrabando depois de terem acumulado capital e poder no violento processo de conversão de terras em domínio português e transformação de não brancos em trabalhadores compulsórios na virada do século XVII para o XVIII.

A existência da feira de Capuame nos demonstra o nível de cisão em que a sociedade colonial se encontrava no período setecentista. Uma feira especializada só tem razão de ser dentro de uma sociedade em que a produção é majoritariamente voltada para a comercialização e pouco resta de produção das próprias condições de vida.

Sendo assim, acentuar o papel relevante da economia pecuária ou a dinâmica da feira de Capuame é praticamente demonstrar o nível generalizado de exploração e expropriação em que a colônia se encontrava no século XVIII, mesmo que houvesse ainda brechas e espaços de sombra para a reprodução mesmo que momentânea de experiências divergentes daquelas desejadas.

O mais assustador em estudar o período setecentista é observar do alastramento e generalização de uma dinâmica de economia de mercado que tende a se espraiar pelas diversas esferas de sociabilidade. Evidente que aqui estamos analisando de um ponto de vista privilegiado na medida em que já sabemos o final da história: o catastrófico movimento 
generalizado de reprodução de uma sociabilidade reificada. ${ }^{1}$ Admitir isso não significa aceitar o processo como natural. Este diagnóstico pode estar consoante a uma consciência de que este não é o sentido único da História e muito menos a única possibilidade de mediação social.

1. Renata Rente. op. cit. p. 189. 


\section{FONTES E BIBLIOGRAFIA}

\section{FONTES MANUSCRITAS}

\section{Arquivo Histórico Ultramarino (AHU) Projeto Resgate.}

Capitania da Bahia: AHU_ACL_005.

Capitania do Pernambuco: AHU_ACL_015.

Capitania do Piauí: AHU_CL_CU_016.

\section{Arquivo Municipal de Salvador (AMS)}

"Registro de entrada do gado 1784-1811"

“Ofícios ao Governo 1712-1737”

\section{Arquivo Público do Estado da Bahia (APEB)}

Secção Judiciária: Inventários

Secção Colonial

\section{Biblioteca Brasiliana Guita e José Mindlin}

CASTELO BRANCO, Antonio Gomes Ferrão. Borrador em que lanço todas as cartas que escrevo, principiado em agosto de 1742, estando na Babia (século XVIII). São Paulo, Coleção José Mindlin [transcrito por Rosana Gonçalves e gentilmente cedido por Prof. Dr. Istvan Jancsó]

\section{FONTES IMPRESSAS}

Anais do Arquivo Publico da Bahia. Salvador, vol.26, 1942.

ANTONIL, André João. Cultura e Opulência do Brasil por suas drogas e minas etc. [1711] (Introdução e notas de Andrée Mansuy Diniz Silva). São Paulo, Edusp, 2007.

BLUTEAU, Raphael. Vocabulario Portuguez \& Latino, aulico, anatomico .... Coimbra, 1728.

CALDAS, José Antonio. Notícia geral de toda esta capitania da Babia desde o seu descobrimento até o presente ano de 1759. Salvador, 1951.

CARDIM, Fernão. Tratados da terra e gente do Brasil. Belo Horizonte, Itatiaia/ Edusp, 1980.

DELGADO, Joaquim Quaresma . "Derrota da Cidade da Bahia para as Minas da Jacobina." Erivaldo Fagundes Neves e Antonio Miguel (org.). Caminhos do sertão: 
ocupação territorial, sistema viário e intercâmbios coloniais dos sertões da Babia. Salvador, Arcádia, 2007.

Documentos Históricos do Arquivo Municipal. Salvador, vol. 10 (1751-1765), 1996.

Documentos Históricos da Biblioteca Nacional . Rio de Janeiro, Biblioteca Nacional, 19281955 ,

110 vols.

MAXIMILIANO, (Príncipe de Wied-Neuwied). Viagem ao Brasil. São Paulo, Itatiaia / EDUSP, 1989 [1816].

NANTES, Pe. Martinho de. Relação de uma missão na rio São Francisco. São Paulo, Nacional, 1979.

“ROTEIRO, do Maranhão a Goiaz pela Capitania do Piauhi," [177-]. RIHGB, Rio de Janeiro, v. LXII, p. 60-161, 1900.

SILVA, Cel. Ignácio Accioli de Cerqueira e. Memórias Históricas e Políticas da Província da Babia (anotado por Braz do Amaral), Salvador, Imprensa Official do Estado, 1937.

VIDE Dom Sebastião Monteiro da. Constituições Primeiras do Arcebispado da Babia. (Impressas em Lisboa no ano de 1719, e em Coimbra em 1720. São Paulo): Tip. 2 de Dezembro, 1853.

VILHENA, Luís dos Santos. A Bahia do século XVIII. Itapuã, Salvador, 1969.

\section{BIBLIOGRAFIA}

ABREU, João Capistrano. Capitulos de história colonial: 1500-1800 (1907) \& Os caminhos antigos e o povoamento do Brasil. Brasília, EUnB, 1984.

ABREU, Wlisses Estrela de Albuquerque. Senhores e escravos do sertão: espacialidades de poder, violência e resistência, 1850-1888. UFCG, Campina Grande, 2011.

ADAN, Caio Figueiredo Fernandes. Colonial Comarca de Ilhéus: soberania e territorialidade na América Portuguesa (1763-1808). Salvador, UFBA, 2009.

ADORNO, T.W. e HORKEIMER, M. Dialética do Esclarecimento. São Paulo, Nova Cultural, 1985.

AGAMBEN, Giorgio. "Lógica da Soberania". Homo sacer: o poder soberano e a vida nua I. Belo Horizonte, 2002.

ALADREN, Gabriel. "Estancieiros escravistas na fronteira rio-grandense: A estrutura da posse de escravos na região de pecuária (Jaguarão e Cachoeira, Rio Grande do Sul, 1799-1840)". Hermes \& Clio, São Paulo, agosto de 2011.

ALENCASTRO, Luis Felipe. Trato dos Viventes: formação do Brasil no Atlântico Sul, séculos XVI e XVII. São Paulo, Companhia das Letras, 2000.

ALFREDO, Anselmo. Índio. Questão de majestade: a problemática indígenae a contradição agrário urbana na ocupação produtiva do Planalto Paulista no século XVIII. São Paulo, USP, 2004.

- "O mundo moderno e o espaço: apreciações sobre a contribuição de Henri Lefebvre.” GEOUSP-Espaço e Tempo, São Paulo, n. 19, pp. 53-70, 2006. 
ALMEIDA, Aluísio de. Tropeirismo e a feira de Sorocaba. Sorocaba, Luzes Gráfica Editora.1968.

ALMEIDA, Carla Maria Carvalho; OLIVEIRA, Mônica Ribeiro (orgs.). "Circuito econômico regionais" (Parte V). In: Nomes e Números. Alternativas metodológicas para a história econômica e social. Juiz de Fora, UFJF, 2006.

ALMEIDA, Kátia Lorena Novais. Escravos e libertos nas Minas do Rio de Contas - Babia, século XVIII. Salvador, UFBA, 2012.

ALVES, Adriana Dantas Reis. As mulheres negras por cima: o caso de Luiza jeje. Escravidão, familia e mobilidade social - Babia, c.1780 - c.1830 . Niterói, 2010.

AMARAL, Camila Teixeira. As duas Espadas do Poder: As relações de tensão e conflito entre o poder secular e o poder eclesiástico na Bahia (1640-1750). Salvador, UFBA, dissertação de mestrado, 2012.

ANASTASIA, Carla Maria Junho. A Geografia do Crime: violência nas Minas Setecentistas. Belo Horizonte, Ed. UFMG, 2005.

Vassalos Rebeldes: Violência coletiva nas Minas na primeira metade do Século XVIII. Belo Horizonte, C/Arte, 1998.

ALCANTARA, Denilson Moreira de; GERMANIAS, Guiomar Inez. Comunidades de Fundo de Pasto e Fecho de Pasto na Babia: luta na terra e suas espacializações. Disponível em:

http:/ /www.geografar.ufba.br/site/arquivos/biblioteca/publicacoes/1fc7a 7b4 5a4d9d24bf645b8a9e99f120.pdf, acessado em 02/08/2012.

ANDRADE, Manuel Correia de. Áreas de dominio da pecuária extensiva e semi-intensiva na Babia e Norte de Minas Gerais. Recife, Ministério do Interior/Superintendência do Desenvolvimento do Nordeste / Superintendência Adjunta de Planejamento / Coordenação de Planejamento Regional / Divisão de Política, 1982.

A terra e o homem no nordeste: contribuição ao estudoi da questão agrária no nordeste. São Paulo, Cortez, 2005.

ARAUjO, Giovanna de Aquino Fonseca. Continuidade e descontinuidade no contexto de globalização: um estudo de feiras em Portugal e Brasil (1986-2007). Minho/ Salvador, Universidade do Minnho/ UFBA, 2011.

ARAUjO, Luis Antonio Silva. Contratos e tributos nas Minas setecentistas: O estudo de um caso - João de Souza Lisboa (1745-1765) . Niterói, UFF, 2002.

ARRAES, Damião Esdras Araújo. Curral de reses, curral de almas: urbanização do sertão nordestino entre os séculos XVII e XIX. São Paulo, USP, 2012.

AZEVEDO, Thales de. Povoamento da Cidade de Salvador. Salvador, Itapuã, 1969.

BACELLAR, Carlos de Almeida Prado. Viver e sobreviver em uma vila colonial: Sorocaba, séculos XVIII e XIX. São Paulo, Annablume/ Fapesp, 2001.

BANNER, Stuart. How the indians lost their land: law and power on the frontier. London, Belknap, 2007.

BARICKMAN, B. J. Um contraponto baiano: açúcar, fumo, mandioca e escravidão no Recôncavo, 1780-1860. Rio de Janeiro, Civilização Brasileira, 2003.

BARROSO, Gustavo. Terra do sol: natureza e costumes do norte. Rio de Janeiro, Livraria São José, 1956.

BENJAMIM, Walter. Obras Escolbidas. São Paulo, Brasiliense, 1987, Vol. 1. 
BOAVENTURA, Eurico Alves. Fidalgos e vaqueiros. Salvador, UFBA/ Centro Editorial e Didático, 1989.

BORREgO, Maria Aaprecida Menezes. A teia mercantil: negócios e poderes em São Paulo colonial (1711-1765). São Paulo, USP, 2006.

BOSERUP, Ester. The conditions of agricultural growth. The economics of agrarian change under population pressure. London, George Allen \&Unwin Ltd. / Ruskin House 1965

BOSI, Alfredo. Dialética da Colonização. São Paulo, Cia das Letras, 1992.

BOXER, Charles. A idade de ouro do Brasil. (Dores de Crescimento de uma Sociedade Colonial). São Paulo, Companhia Editora Nacional, 1963.

BRAGA, Isabel Drumond. "Influências estrangeiras nos livros de cozinha portugueses (século XVI-XIX): alguns problemas de análise", Estudos em Homenagem ao Prof. Doutor José Marques, vol. 2, Porto, 2006, p. 237-247.

BRAUDEL, Fernand. Civilização Material, Economia e Capitalismo: séculos XVI-XVIII. São Paulo, Martins Fontes, 1996. 3 volumes.

BRITO, Raphael Freitas. "Devo que pagarei”: sociedade, mercado e práticas creditícias na comarca do Rio das Velhas (1713-1773). Belo Horizonte, UFMG, 2005.

BURNARD, Trevor Burnard. Mastery, Tyranny, and Desire: Thomas Thistlewood and His Slaves in the Anglo-Jamaican World, 2004.

CABRAL, Maria do Socorro Coelho. Caminhos do gado: conquista e ocupação do sul do Maranbão. São Luís, SIOGE, 1992.

CALDEIRA, Clovis. Mutirão: formas de ajuda mútua no meio rural. São Paulo, Nacional, 1956.

CAlmon, Pedro. História da Casa da Torre: uma dinastia de pioneiros. Rio de Janeiro, José Olympio, 1939.

CAMPOS, Pedro Henrique Pedreira. Nos caminhos da acumulação. Negócios e poder no abastecimento de carnes verdes para a cidade do Rio de Janeiro (1808-1835). São Paulo, Alameda, 2010.

CANDIDO, Antonio. Os parceiros do Rio Bonito: Estudos sobre o caipira paulista e a transformação de seus meios de vida. Rio de Janeiro, Ouro sobre Azul, 2010.

CARDOSO, Domingos Benício Oliveira Silva; QUEIROZ, Luciano Paganucci de. "Diversidade de leguminosae nas caatingas de Tucano, Bahia: implicações para a fitogeografia do semi-árido do Nordeste do Brasil." Rodriguésia (Impresso), v. 58, p. 379-391, 2007.

CARNEIRO, Henrique. Comida e sociedade: uma história da alimentação. Rio de Janeiro, Campus, 2003.

CARRARA, Ângelo Alves. Minas e Currais. Producão rural e mercado interno de Minas Gerais 1674-1807. Juiz de Fora, Ed. UFJF, 2007.

CASCUDO, Luis da Câmara. História da alimentação no Brasil: pesquisa e notas. Belo Horizonte, Itatiaia, 1983.

CHANDLER, Billy James. Os Feitosas e o Sertão dos Inhamuns: a história de uma comunidade no nordeste do Brasil (1700-1930). Fortaleza, Rio de Janeiro, 1981.

CHEVALIER, François. La formacion de los latifundios em México. Haciendas y sociedad em los siglos XVI, XVII e XVIII. México, Fondo de Cultura Econômica, 1976.

CHINA, José D'Oliveira. Ciganos do Brasil: subsídios históricos, ethnographicos e linguísticos. São Paulo, Imprensa Oficial do Estado, 1936. 
CORTESÃO, Jaime. Raposo Tavares e a Formação Territorial do Brasil. Lisboa, Portugália, 1966.

COSTA, Francisco Augusto Pereira da. Cronologia histórica do estado do Piauí. Rio de Janeiro, Artenova, 1974.

CURTO, Diogo Ramada. O Atlântico Sul no século Barroco (1580-1720). 2014 (no prelo).

DANTAS, Monica. Fronteiras Movediças: a comarca de Itapicuru e a formação do arraial de Canudos. São Paulo, Hucitec, 2007.

- "Povoamento e ocupação do sertão de dentro baiano (Itapicuru,1549- 1822)”. Penélope, Oeiras, v.23, 2000, pp.9-30.

(org.) Revoltas, motins, revoluções: homens livres pobres e libertos no Brasil do século XIX. São Paulo, Alameda, 2011.

DAVIS, Mike. Holocaustos Coloniais: Clima, fome e imperialismo na formação do Terceiro Mundo. Rio de Janeiro, Record, 2002.

DIAS, Marcelo Henrique. Economia, sociedade e paisagens da capitania e comarca Ilhéus no período colonial. UFF, Niterói, 2007.

DIAZ, Diaz; MARKGRAF, Vera. El Niño Historical and Paleoclimatic Aspects of the Southern Oscillation. London, Cambridge University Press, 1993.

DINIZ, Nathália Maria Montenegro. Um sertão entre tantos outros: Fažendas de gado nas Ribeiras do Norte. USP, São Paulo, 2013.

Paulo, 2008 - Velhas fazendas da ribeira do Seridó. USP, São

DÓREA, Luís Eduardo. Os nomes das ruas contam histórias. Salvador, Camara Municipal de Salvador, 1999.

DORNAS FILHO, João. "Os ciganos em Minas Gerais”. RIHGMG, Rio de Janeiro, 1948. p.147-151.

ELLIS, Myriam. O contrato do sal no Brasil Colonial. São Paulo, USP, 1955.

FALCI, Miridan Knox Falci. "Mulheres do sertão nordestino.” Mary Del Priori (org.) História das mulheres no Brasil. São Paulo, Contexto, 2009.

FARAGE, Nadia. As muralhas dos sertões: os povos indígenas no Rio Branco e a colonização. São Paulo, 1986

FERLINI, Vera Lucia Amaral. Açúcar e coloniz̧ação. São Paulo, Alameda, 2010.

Terra, trabalho e poder: o mundo dos engenhos no Nordeste colonial. São Paulo, Brasiliense, 1988.

FERRARO JÚNIOR, Luiz Antonio. Entre a invenção da tradição e a imaginação da sociedade sustentável: estudo de caso dos fundos de pasto na Babia. Brasília, UnB, 2008.

FERREIRA, Elisangela Oliveira. Entre vazantes, caatinga e serras: trajetórias familiares e uso social do espaço do sertão do São Francisco, no século XIX. Salvador, UFBA, 2008.

FERRO, Carolina Chaves. Terremoto em Lisboa, tremor na Babia. Um protesto contra o donativo para a reconstrução de Lisboa. Niterói, UFF, 2009.

FIGUEIREDO, Luciano Raposo. Revolta, fiscalidade e identidade colonial na América Portuguesa: Rio de Janeiro, Babia e Minas (1640-1761). São Paulo, USP, 1996.

FLANDRIN, Jean- Louis; MONTANARI, Massimo (org.) História da alimentação. São Paulo, Estação Liberdade, 1998. 
FONSECA, Mariana Bracks. Nzinga Mbandi e as guerras de resistência em Angola. Século XVII. São Paulo,USP, 2012.

FONSECA, Mônica Sepúlveda. Viúvas na corte do sertão: família, gênero e riqueza em Juazeiro (1850-1890), Salvador, UFBA, 2011.

FONSECA, Rogério Gerolineto. A pedra e o pálio: relações sociais e cultura na Capitania do Piauí no século XVIII. Teresina, UFPI, 2010.

FOTTA, Martin. The bankers of the backlands: financialisation and the Calon-Gypsies in Babia. London, University of London, 2012.

FOUCAULT, Michel. Segurança, território, população. São Paulo, Martins Fontes, 2008.

FRAGA FILHO, Walter. Mendigos, moleques e vadios na Babia do século XIX. São Paulo/ Salvador, Hucitec / EdUFBA, 1995.

FRAGOSO, João; FLORENTINO, Manolo. Arcaísmo como Projeto: mercado atlântico, sociedade agrária e elite mercantil em uma economia colonial tardia. Rio de Janeiro, c. 1790 - c. 1840. Rio de Janeiro, Civilização Brasileira, 2001.

; BICALHO, Maria Fernanda; GOUVÊA, Maria de Fátima (orgs.). O Antigo Regime nos Trópicos: a dinâmica imperial portuguesa (séculos XVI-XVIII). Rio de Janeiro, Civilização Brasileira, 2001.

FREIRE, Felisbelo. Historia Territorial do Brazil. Rio de Janeiro, Typ. do "Jornal do Commercio de Rodrigues \&C, 1906.

FREIRE, Luiz Cleber Moraes. Nem tanto ao mar nem tanto a terra: Agropecuária, escravidão e riqueza em Feira de Santana, 1850-1888. Salvador, UFBA, dissertação de mestrado defendida em 2007.

FREYRE, Gilberto. Sobrados e Mucambos. Decadência do patriarchado rural no Brasil. São Paulo, Companhia Editora Nacional, 1936.

FURTADO, Celso. Cultura e desenvolvimento em época de crise. Rio de Janeiro, Paz e Terra, 1984.

Formação econômica do Brasil. São Paulo, Ed. Nacional, 1982.

FURTADO, Junia. Homens de negócio: a interiorização da metrópole e do comércio nas Minas setecentistas. São Paulo, Hucitec, 1999.

(org.). Sons, formas, cores e movimentos na modernidade atlantica. Europa, Américas e África. Belo Horizonte, Annablume, 2008.

GALVÃO, Hélio Galvão. O mutirão no nordeste. Rio de Janeiro, Ministério da Agricultura, 1959.

GASPAR, Jorge. As feiras de gado da Beira Litoral. Lisboa, 1986.

GAUDEMAR, Jean-Paul de. Mobilidade de trabalho e acumulação do capital. Lisboa, Estampa, 1977.

GIL, Tiago Luís. Coisas do Caminho. Tropeiros e seus negócios do Vaimão à Sorocaba. (17801810), Rio de Janeiro, UFRK, 2009.

GIROLDO, Larissa. Terracetes de pisoteio de gado mudanças morfo-pedologicas em vertente amostral na bacia hidrogŕofica do rio Jacareí, Serra da Mantiqueira - SP. São Paulo, USP, 2013.

GOMES, Flávio dos Santos. A hidra e os pântanos: mocambos, quilombos e comunidades de fugitivos no Brasil ( séculos XVII-XIX). São Paulo, UNESP/ Polis, 2005.

GOMES, Flávio dos Santos; REIS, João José (org.). Liberdade por um fio: história dos Quilombos no Brasil. São Paulo, Companhia das Letras, 2005. 
GORENDER, Jacob. O Escravismo Colonial, São Paulo, Ática, 1988.

GOULART, José Alípio. Brasil do boi e do couro. Rio de Janeiro, Edições GRB, 1965.

GRAHAM, Richard. Alimentar a cidade: das vendedoras de rua à reforma liberal (Salvador, 1780-1860). São Paulo, Companhia das Letras, 2013.

GRUZINSKI, Serge. O pensamento mestiço. São Paulo, Companhia das Letras, 2001.

GUIMARÃES, Dulce Maria Pamplona. A celebração da modernidade: a feira e a festa nas exposições agropecuárias do nordeste paulista. São Paulo, USP, 1996.

HALL, Douglas. In Miserable Slavery: Thomas Thistlewood in Jamaica, 1750-86. London, 1989.

HAMESITER, Martha Daisson. O Continente do Rio Grande de São Pedro: os homens, suas redes de relações e suas mercadorias semoventes (c. 1727 - c. 1763). Rio de Janeiro, 2002.

HEREDA, Jorge Fontes. Quando a lama virou terra ... O caso da urbainzação de Alagados. São Paulo, USP, dissertação de mestrado, 1991.

HOLLANDA, Sérgio Buarque. Caminhos e fronteiras. São Paulo, Companhia das Letras, 1995.

(dir.). História Geral da Civilização Brasileira. Tomo I: A época colonial. Segundo Volume: Administração, economia, sociedade. São Paulo, Difel, 1981.

- Visão do Paraíso: os motivos edênicos no descobrimento e colonização do Brasil. São Paulo, Brasiliense, 1996.

IVO, Isnara Pereira. Homens de caminho. Trânsitos, comércio e cores nos sertões da América Portuguesa - século XVIII. Belo Horizonte,UFMG, tese de doutorado, 2009.

JANCSÓ, Istvan; KANTOR, Íris (org.). Festa: cultura \& sociabilidade na América Portuguesa. Volume II. São Paulo, Hucitec, 2001.

JANCSÓ, Istvan. Na Babia contra o Império: história do ensaio de sedição de 1798. São Paulo, Hucitec, 1996

KOK, Gloria. O sertão itinerante. Expedições da Capitania de São Paulo no século XVIII. São Paulo, Hucitec, 2004.

KOSELLECK, Reinhart. Crítica e crise: uma contribuição à patogênese do mundo burguês. Rio de Janeiro, 2009.

KURZ, Robert. Com todo vapor ao colapso. Juiz de Fora, Ed. UFJF, 2004.

KURZ, Robert. Razão Sangrenta: ensaios sobre a crítica emancipatória da modernidade capitalista e de seus valores ocidentais. São Paulo, Hedra, 2010.

LAPA, José Roberto do Amaral. A Babia e a Carreira da Índia. São Paulo, Hucitec, 2000.

LEITE, Ana Carolina Gonçalves. A modernizaçãa do Vale do Jequitinhonha mineiro e o processo de formação do trabalhador "bóia-fria" em suas condições regionais de mobilização do trabalho. São Paulo, USP, 2010.

LENHARO,Alcir. As tropas de moderação. (O abastecimento da Corte na formação política do Brasil-1808-1842). Simbolo, São Paulo, 1979

LENK, Wolfgang. Guerra e Pacto Colonial: exército, fiscalidade e administração colonial na Babia (1624-1654). Campinas, Unicamp, 2009. 
LEWIN, Linda. "Some historical implications of kinship organization for family-based politics in the brazilian northeast". Comparative Studies in Society and History, v. 21, n. 2, april 1972.

LINHARES, Maria Yedda. História do Abastecimento. Brasília, Binagri, 1979.

"A pecuária e a produção de alimentos na colônia". Tamás Szmrecsányi (org.) História Econômica do Período Colonial. São Paulo, 2002

LOPES, Gustavo Acioli. Negócio da Costa da Mina e Comércio Atlântico. Tabaco, Açúcar, Ouro e Tráfico de Escravos: Pernambuco (1654-1760). USP, São Paulo, 2008.

LOPES, Nei. Enciclopédia Brasileira da Diáspora Africana. São Paulo, Selo Negro, 2004.

LOPES, Rodrigo F. Nos currais do Matadouro Público: o abastecimento de carne verde em Salvador no século XIX (1830-1873). Salvador, UFBA, tese de doutorado, 2009.

MACEDO, Jozé Norberto. Fažendas de Gado no vale do São Francisco. Rio de Janeiro, Ministério da Agricultura, Serviço de Informação Agrícola, 1952.

MARQUESE, Rafael de Bivar. "A dinâmica da escravidão no Brasil: resistência, tráfico negreiro e alforrias." Novos Estudos - Cebrap, 2006, n. 74, p. 107-123.

MARTINS, José de Souza. O cativeiro da terra. São Paulo, Hucitec, 1986.

MARTINS, Ronaldo Luiz. Mercadão de Madureira: caminhos de comércio. Rio de Janeiro, Condomínio do Entreposto Mercado do Rio de Janeiro, 2009.

MARX, Karl. "O processo global de produção capitalista." O Capital. Livro 3, vol. 4, São Paulo, 1988.

MASCARENHAS, Maria José Rapassi. Fortunas Colonias - Elite e riqueza em Salavador (1760-1808). São Paulo, USP, 1998.

MATTOSO, Katia M. De Queirós. Babia, século XIX. Uma provincia no Império. Rio de Janeiro, Nova Fronteira, 1992.

"Os preços na Bahia de 1750 a 1930". L'bistorie quantitative du Brésil, 1800-1930. Paris, 167-182.

MELLO, Alexandre José de Moraes. Os ciganos no Brasil e o cancioneiro dos ciganos. Belo Horizonte, Itatiaia, 1981.

MELlo, Evaldo Cabral de. O Negócio do Brasil. Portugal, os Países Baixos e o Nordeste, 1641-1669, Rio de Janeiro, Topbook, 1998.

MENEZES, George Rocha. Lutas politicas e crise social: a elite politica cearense na década de 1870. Fortaleza, UFC, dissertação de mestrado, 2006.

MENZ, Maximiliano. Entre dois Impérios: Formação do Rio Grande na Crise do Antigo Sistema Colonial (1777-1822). São Paulo, USP, 2006.

MESZÁROS, István. Estrutura Social e Formas de Consciência. A determinação social do método. São Paulo, Boitempo, 2009.

MONTEIRO, Jonh Manuel. Negros da Terra: indios e bandeirantes nas origens de São Paulo. São Paulo, Companhia das Letras, 2000.

MOTT, Luiz R.B. Babia: Inquisição e Sociedade. Salvador, Edufba, 2010.

. "Cotidiano e vivência religiosa: entre a capela e o calundu". Fernando Antonio Novais (org.) História da Vida Privada no Brasil, vol. 1, São Paulo, 1997.

Piaui Colonial: população, economia e sociedade. Teresina, Projeto Pretônio Portela, 1985. 
MOTTA, Marcia. Direito à terra no Brasil: a gestão do conflito (1795-1824). São Paulo, Alameda, 2009.

. "Sesmeiros e posseiros nas malhas da lei." Nas Fronteiras do poder: conflitos de terra e direito agrário no Brasil de meados do século XIX. Unicamp, Campinas, 1996.

NASCIMENTO, Joana Medrado. Terra, laço e moirão: relações de trabalho e cultura politica na pecuária (Geremoabo, 1880-1900). Campinas, Unicamp, dissertação de mestrado, 2008.

NEVES, Erivaldo Fagundes; MIGUEL, Antonieta (org.), Caminhos do sertão: ocupação territorial, sistema viário e intercâmbios coloniais dos sertões da Babia. Salvador, Arcádia, 2007.

NEVES, Erivaldo Fagundes. Estrutura Fundiária e Dinâmica Mercantil. Alto Sertão da Babia, séculos XVIII e XIX. Salvador / Feira de Santana, EDUFBA / UEFS, 2005.

Uma comunidade sertaneja: da sesmaria ao minifúndio. Um estudo de história regional e local. Salvador / Feira de Santana, EDUFBA / UEFS, 2008.

(org.). Sertões da Babia. Formação Social, Desenvolvimento Econômico, Evolução Política e Diversidade Cultural. Salvador, 2011

NEVES, Juliana Brainer Barroso. Colonização e Resistência no Paraguaçu : Babia, 1530 1678. Salvador, UFBA, dissertação de mestrado, 2008.

NOGUEIRA, Gabriela Amorim. "Viver por si", viver pelos seus: família e comunidades de escravos e forros no "certam de sima do Sam Francisco" (1730-1790). Santo Antonio de Jesus, UNEB, 2011.

NOVAIS, Fernando Antonio. Portugal e Brasil na Crise do Antigo Sistema Colonial (17771808). São Paulo, Hucitec, 2001.

NOVAIS, Idelma Aparecida Ferreira. Produção e Comércio na Imperial Vila da Vitória (Babia, 1840-1880). Salvador, UFBA, 2008.

NUNES, Odilon. Pesquisas para a história do Piauí. Vol. 1. Rio de Janeiro, Artenova, 1975.

OLIVEIRA, Francisco. Crítica à razão dualista. O ornitorrinco. São Paulo, Boitempo, 2003.

OLIVEIRA JUNIOR, Paulo Cavalcanti. Negócio de trapaças: Caminhos e descaminhos na América Portuguesa (1700-1750). São Paulo, USP. Tese de doutorado, 2002.

OLIVEIRA FILHO, Roque Felipe de Oliveira. Crimes e Perdões no ordem jurídica colonial. Bahia (1750-1808). Salvador, UFBA, tese de doutorado, 2009.

OSÓRIO, Helen. "As elites economicas e a arrematação dos contratos reais: o exemplo do Rio Grande do Sul ( século XVIII)". João Fragoso, Maria Fernanda Bicalho, Maria de Fátima Gouvea(org.). O Antigo Regime nos Trópicos. Rio de Janeiro, 2001, p. 107-137.

PAIM, Marcia Regina da Silva. Do Sete a São Joaquim: o cotidiano de "mulheres de saia" $e$ homens em feiras soteropolitanas (1964-1973). Salvador, USP, 2005. 
PALACIOS, Guillermo. Cultivadores Libres, Estado y Crisis de la Esclavitud en Brasil en la Época de la Revolución Industrial. Mexico, El Colégio de México, 1998.

PARAÍSO, Maria Hilda Boqueirão. O tempo da dor e do trabalho: a conquista dos territórios indígenas nos sertões do Leste. São Paulo, USP, 1998

PARKER, Geoffrey. El ejército de Flandes y el Camino Español (1567-1659): La logística de la vitoria y derrota de España en las guerras de los Países Bajos. Madrid, 1985.

PÉCORA, Alcir e SCHWARTZ, Stuart(orgs.). As excelências do governador: o panegirico fúnebre a D. Afonso Furtado de Juan Lopes Sierra (Babia, 1676). São Paulo, Cia. das Letras, 2002.

PEIXOTO, Tatiana da Cunha. Os mandarins do sertão: os criadores de gado do São Francisco (1650-1750). Belo Horizonte, UFMG, 2006.

PEREIRA, Antonio Roberto Alves. Família Escrava e pecuária: revisão historiográfica e perspectivas de pesquisas. São Paulo, USP, dissertação de mestrado, 2011.

PESSOA, Angelo Emílio da Silva. As ruinas da tradição: a casa da Torre de Garcia D'Ávila - familia e propriedade no nordeste colonial, São Paulo, USP, 2003.

PINHO, Wanderley. Historia de um engenho no Recôncavo. Sao Paulo, Ed. Nacional, 1982.

POLANYI, Karl. A Grande Transformação: as origens do nosso tempo. Rio de Janeiro, Campus, 1980.

POPPINO, Rollie. Feira de Santana. Salvador, Itapuã, 1968.

PORTELA, Rafael Davis. Pescadores na Babia do século XIX. Salvador, UFBA, 2012.

PRADO, Fabrício Pereira. A colonia de Sacramento: o extremo sul da América Portuguesa. Porto Alegre, 2002.

PRADO JUNIOR, Caio. Formação do Brasil Contemporâneo. São Paulo, Brasiliense, 1986.

PRIORE, Mary Del. "Ritos da vida privada". Fernando Novais (coord.) História da Vida privada no Brasil. São Paulo, 1997, p. 275-330.

PUNTONI, Pedro. A Guerra dos Bárbaros: povos indígenas e a colonização do sertão Nordeste do Brasil, 1650-1720. São Paulo, Hucitec/ Edusp, 2002.

QUADROS, Danilo Gusmão de. Sistemas de produção dos bovinos de corte. Salvador, UNEB, 2005.

REGO, Junia Motta Antonaccio Napoleão do. Dos sertões aos mares: história do comércio e dos comerciantes de Parnaíba (1700-1950). Niterói, UFF, 2010.

REIS, João José; AGUIAR, Márcia Gabriela D. de. "Carne sem osso, farinha sem caroço: o motim de 1858 contra a carestia na Bahia". Revista de História, 135 (1996), p. 133-160.

RENTE, Renata Santos. Região Geográfica e o regional na literatura brasileira: a representação do sertão em Guimarães Rosa e os debates sobre a formação do Brasil, São Paulo, USP, 2013.

RIBEIRO, Flavio Diniz. Para uma crítica a ideia de desenvolvimento. São Paulo, USP, 2001.

RICUPERO, Rodrigo. Formação da elite colonial: Brasil, c. 1530 - 1630. São Paulo, Alameda, 2008.

ROLIM, Leonardo Cândido. "Tempo das carnes" no Siara Grande: dinâmica social, produção e comércio de carnes secas na Vila de Santa Cruz do Aracati. (c.1690-c. 1802), João Pessoa, UFPB, 2012. 
RUSSELL-WOOD,A. J. R. Fidalgos and philantropists: the Santa Casa da Misericórdia of Babia (1550-1755). Berkley, Univ. California Press, 1968.

Civilização Brasileira, 2005.

SÁ, Andréa Alves de. Território de uso comum das comunidades tradicionais: uma visão jus socioambiental do criar, fazer e viver dos fundos de pasto da Babial Brasil. Curitiba, UFPR, 2010.

SALES, Marta Celina Linhares. Estudos climáticos, morfo-pedológicos e fito-ecológicos no núlceo de desertificação de Irauçuba-CE. USP, São Paulo, 2003.

SANTOS, Fabrício Lyrio. Da catequese à civilização: colonização e povos indigenas na Babia (1750-1800). Salvador, UFBA, tese de doutorado, 2012.

SANTOS, Jadilson Pimentel dos. "Igreja de Santana de Tucano: uma joia Barroca dilapidada." II Encontro Baiano de Estudos em Cultura. Feira de Santana, 2009.

SANTOS, Márcio Roberto Alves dos. Fronteiras do sertão baiano: 1640-1750. São Paulo, USP, 2009.

SANTOS, Raphael Freitas. Devo que pagarei: sociedade, mercado e práticas crediticias na comarca do Rio das Velhas - 1713-1773, Belo Horizonte, UFMG, 2005.

. Minas com Babia: mercados e negócios em um cirucito mercantil setecentista. Niterói, UFF, tese de doutorado, 2013.

SANTOS, Rui. "Mercados, poderes e preços: a marchantaria em Évora ( séculos XVII-XIX)". Penélope, 21, 1999: 63-93.

SANTOS FILHO, Lycurgo. Uma comunidade rural no Brasil Antigo (aspectos da vida patriarcal na sertão da Babia nos séculos XVIII e XIX). São Paulo, Ed. Nacional, 1956.

SATO, Márcia Helena Yamamoto. Análise de estruturas em taipa de pilão. São Paulo, USP, 2011.

SCHMITT, Carl. "La toma de la tierra em un Nuevo Mundo." El Nomos de la Tierra: em el derecho de gentes del "Jus publicum europaeum". Madrid, 1979.

SCHWARTZ, Stuart B. Segredos internos: engenhos e escravos na sociedade colonial. São Paulo, Companhia das Letras, 1999.

"Hurricanes and the shaping of circum-caribean societies." The Florida Historical Quarterly. Vol. 83, n. 4, spring, 2005.

SENA, Consuelo Pondé de. Introdução ao estudo de uma comunidade do agreste baiano (Itapicuru, 1830-1892). Salvador, Fundação Cultural do Estado da Bahia, 1979.

SERVILHA, Mateus de Moraes. O vale do Jequitinhonba entre a "di-visão" pela pobreza e sua ressignificação pela identificaşão regional. Niterói, UFF, tese de doutorado, 2012.

SILVA, Célia Nonata da, "Sertão, Zona Mestiça". In: Territórios de mando. Bandistismo em Minas Gerais, século XVIII. Belo Horizonte, Crisálida, 2007. pp.49-139.

SILVA, Innocencio Francisco da Silva. Diccionário Bibliographico Portuguez aplicados a Portugal e ao Brasil, Lisboa, Imprensa Nacional, 1859.

SILVA, Flávio Marcus da. Subsistência e poder. A política de abastecimento alimentar nas Minas setecentistas. UFMG, Belo Horizonte, 2002.

SILVA, Francisco Carlos Teixeira da. Morfologia da escassez: crises de fome e política econômica no Brasil Colonial. Niterói, UFF, 1991. 
SILVA, Kalina Vanderlei P. da. O miserável soldo e a boa ordem: Militarização e marginalidade na Capitania de Pernambuco dos séculos XVII e XVIII. Recife, 2000

Nas solidões vastas e assustadoras. A conquista do sertão de Pernambuco pelas vilas açucareiras nos séculos XVII e XVIII. Recife, Cepe, 2010.

SIMONSEN, Roberto. História Econômica do Brasil (1500-1820). São Paulo, Edi. Nacional, 1957.

SHEPHERD, Verene A. . "Livestock and sugar: aspects of Jamaica's agricultural development from the late seventheenth to the early nineteenth century." The Historical Journal, 34, 3 (1991), p. 627-643.

SOUSA, Avanete Pereira. Poder local, cidade e atividades econômicas (Babia, século XVIII). São Paulo, USP, tese de doutorado, 2003.

SOUSA, José Weyne de Freitas Sousa. Política e seca no Ceará. Um projeto de desenvolvimento para o Norte (1869-1905). São Paulo, USP, tese de doutorado, 2009.

SOUSA, Maria Aparecida Silva de. A conquista do sertão da Ressaca: povoamento e posse da terra no interior da Babia. Vitória da Conquista, UESB, 2001.

Paulo, 2008.

. Babia: de capitania a província,1808-1823. USP, São

SOUZA, Edison Rodrigues de; MORALES, Walter Fagundes. Prospeçãa Arqueológica e Educação Patrimonial para a linha de transmissão 230 KVI Igaporã - Bom Jesus da Lapa II. Ilhéus, 2013.

SOUZA, Laura de Mello e. O Sol e a Sombra: politica e administração na América portuguesa no século XVIII. São Paulo, Cia. das Letras, 2006.

. "Formas provisórias de existência: a vida cotidiana nos caminhos, nas fronteiras e nas fortificações." Fernando Antonio Novais (org.) História da vida privada no Brasil. Vol. 1: Cotidiano e vida privada na América Portuguesa. São Paulo, Companhia das Letras, 1997. p. 41- 81

SZMRECSÁNYI, Tamás. História Econômica do Período Colonial. São Paulo, Fapesp / Hucitec, 1996.

TAVARES, Georgia da Costa. A atuação dos marchantes no Rio de Janeiro Colonial: estratégias de mercado e redes de sociabilidade no comércio de abastecimento de carne verde (1763-1808). Rio de Janeiro, Arquivo Geral da Cidade do Rio de Janeiro, 2012.

TEDIM, José Manuel. "O triunfo da festa barroca a troca das princesas". Arte efémera em Portugal. Lisboa, 2000.

TEIXEIRA, Marli Geralda. "Revolta dos Búzios ou Conjuração Baiana de 1789: uma chamada para a liberdade". S/d. Disponível em < http://www.educacao.salvador.ba.gov.br/documentos/revolta-dos-buzios.pdf $>$. Acessado em: 11 de novembro de 2012.

THOMPSON, Edward P. Costumes em comum. Estudos sobre a cultura popular tradicional. São Paulo, Cia. das Letras, 1998.

TILLY, Charles. Coerrgão, Capital e Estados Europeus. São Paulo, Edusp, 1996.

(ed.) Historical studies of changing fertility. Princenton, Princenton University Press, 1978. 
TOLEDO, Carlos Almeida. A região das Lavras Baianas. USP, São Paulo, 2008.

TOLEDO, Maria Fátima de Melo. Desolado Sertão. A Colonização Portuguesa do Sertão da Babia (1654-1702). São Paulo, tese de Doutorado, USP, 2006.

VALIM, Patricia. Corporação dos enteados: tensão, contestação e negociação política na Conjuração Baiana de 1798. São Paulo, USP, tese de doutorado, 2012.

VARNHAGEN, Francisco Adolpho. "Gabriel de Soares de Sousa: Memória." Revista do Instituto Histórico e Geográfico Brasileiro, 1858, vol. 21, p. 494.

VASCONCELOS, Albertina Lima. Ouro: conquistas, tensões, poder, mineração e escravidão (Babia, século XVIII). Campinas, Unicamp, tese de doutorado, 1998.

VENÂNCIO, Renato Pinto (org.) Administrando Impérios. Portugal e Brasil nos séculos XVIII e XIX. Belo Horizonte, Traço Fino, 2012.

VIEIRA, Antonio Roberto Alves. Familia escrava e pecuária: revisão bistoriográfica e perspectivas de pesquisas. São Paulo, USP, 2011.

WILLIAMS, Eric. Capitalismo \& Escravidão. São Paulo, Cia. das Letras, 2012.

ZEMELLA, Mafalda. O abastecimento da Capitania das Minas Gerais no século XVIII. São Paulo, Hucitec / Edusp, 1990. 